Portland State University

PDXScholar

Spring 5-18-2015

\title{
Custom Fluorophores for Investigating the Cellular Uptake Mechanisms and Side-Effects of Pharmaceuticals
}

Yu-Hsuan Chu

Portland State University

Follow this and additional works at: https://pdxscholar.library.pdx.edu/open_access_etds

Part of the Chemicals and Drugs Commons, and the Medicinal and Pharmaceutical Chemistry Commons

Let us know how access to this document benefits you.

\section{Recommended Citation}

Chu, Yu-Hsuan, "Custom Fluorophores for Investigating the Cellular Uptake Mechanisms and Side-Effects of Pharmaceuticals" (2015). Dissertations and Theses. Paper 2343.

https://doi.org/10.15760/etd.2340

This Dissertation is brought to you for free and open access. It has been accepted for inclusion in Dissertations and Theses by an authorized administrator of PDXScholar. Please contact us if we can make this document more accessible: pdxscholar@pdx.edu. 
Custom Fluorophores for Investigating the Cellular Uptake Mechanisms and Side-Effects of Pharmaceuticals

\author{
by \\ Yu-Hsuan Chu
}

A dissertation submitted in partial fulfillment of the requirements for the degree of

\author{
Doctor of Philosophy \\ in \\ Chemistry
}

\begin{abstract}
Dissertation Committee:
Robert M. Strongin, Chair

David Stuart

Erik Johansson

Jonathan J. Abramson
\end{abstract}

Portland State University

2015 


\begin{abstract}
There is a significant current need to elucidate the molecular mechanisms of the side-effects caused by widely-used pharmaceuticals. Examples include the acute nephrotoxicity and irreversible ototoxicity promoted by the cationic drugs gentamicin and cisplatin. Gentamicin is an aminoglycoside antibiotic used for the prevention and treatment of life-threatening gram-negative bacterial infections, such as tuberculosis and meningitis. Cisplatin is used to treat a broad spectrum of cancers including head and neck, ovarian, cervical, stomach, bladder, sarcoma, lymphoma, testicular cancer and others.

The objective of this study is to design and synthesize rhodamine derivatives that can be used for the construction of geometrically well-defined cationic drug conjugates. The long-term goal is to use the conjugates as tools to aid in elucidating the properties and identities of ion channels involved in the uptake of cationic pharmaceuticals into kidney and cochlear hair cells. This will shed light on the origin and potential prevention of unwanted side effects such as nephrotoxicity and ototoxicity associated with specific cationic drugs.
\end{abstract}

A series of extended rhodamine analogs with reactive groups for biomolecule conjugation has been synthesized. These fluorophores show similar spectral properties to their prototype, Texas Red succinimidyl ester (TR-SE). However, they contain rigid linkers between the fluorophore and amine-reactive moiety. The resultant gentamicin conjugates of these materials are rigidified enabling one to assess channel pore dimensions without the confounding issue of conjugate folding. Preliminary cell studies are promising, as one observes reduced gentamicin uptake in both kidney and sensory 
hair cell upon systematically increasing the dimension of the fluorophore. This work has enabled us to tentatively assign the maximum dilated MET channel pore size as between $1.44 \mathrm{~nm}$ to $1.56 \mathrm{~nm}$. However, this preliminary finding, though encouraging, needs further validation via ongoing studies with larger diameter fluorophore conjugates,

A cisplatin-Texas Red conjugate has also been synthesized to enable studies of cellular uptake mechanisms. This conjugate preserves not only the spectral properties of Texas Red after conjugation, but also the cytotoxicity of cisplatin. This has been validated in zebrafish. The series of rhodamine probes that have been conjugated to gentamicin should be similarly useful for cisplatin studies. These studies are planned. Additional future work includes the synthesis of semi-flexible (glycol) and flexible (alkyl) linkers to evaluate structure-activity relationships. 


\section{ACKNOWLEDGEMENTS}

I have gained so much help and support from many individuals along the Ph.D. journey. Without their time, attention and thoughtful feedback, I would not be able to accomplish this incredible adventure.

First of all, I am deeply thankful to my advisor, Prof. Robert M. Strongin for his great motivation, advice and care. He has been patient and encouraging to students with new ideas and key insights. He is the one showing me how to be a great chemist. Also, I would like to express my appreciation to Dr. Martha Sibrian-Vazquez, Dr. Jorge O. Escobedo, Dr. Mark Lowry and Dr. Joseph Rajan for their guidance and assistance on my research project. It has been my honor to work and learn with them.

I would like to extend my gratitude to committee members, Prof. Erik Johansson, Prof. David Stuart, Prof. Jonathan J. Abramson and Prof. Reuben H. Simoyi for their constructive comments and suggestions. And special thanks to Prof. Peter S. Steyger and Meiyan Jiang, our collaborators from Oregon Health \& Science University. It's been a privilege to cooperate with them.

I want to thank my colleagues, Jialu Wang, Lei Wang, Aabha Barve and Lovemore Hakuna, over the past five years, for their company and bonds of friendship. In addition, to my best friend and soul mate, Chieh Hsu, thanks for his spiritual support, encouragement and sharing the unforgettable memories with me.

Last but not least, I would like to thank my family, my Dad Lucas Chu, my Mom Ling-Hue Su and my brother Leo Chu. Without their unconditional love and support, I wouldn't be the person I am today. 


\section{TABLE OF CONTENTS}

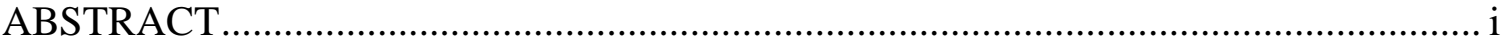

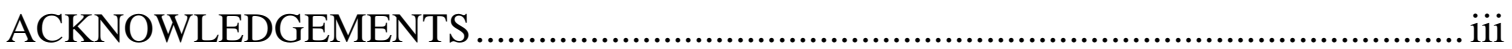

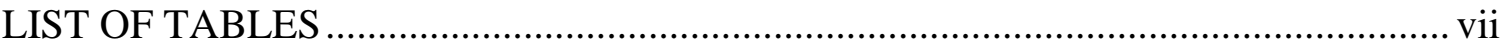

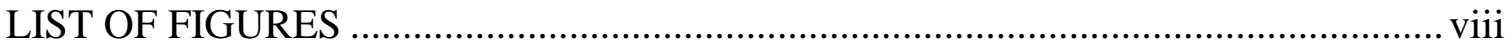

LIST OF ABBREVIATIONS .................................................................................

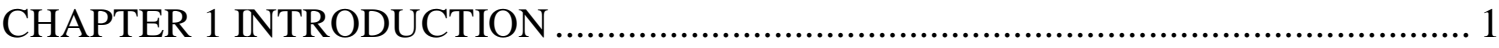

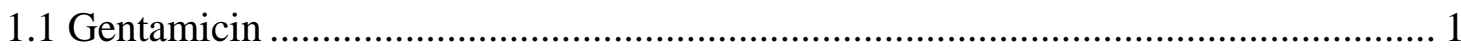

1.2 Bactericidal mechanism of gentamicin ........................................................... 2

1.3 Trafficking routes of gentamicin into the cochlea associated with deafness ............ 3

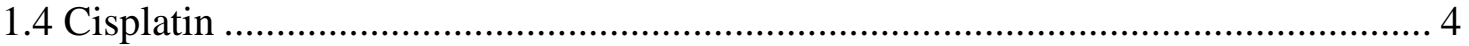

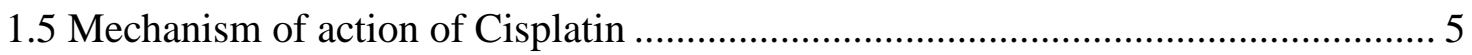

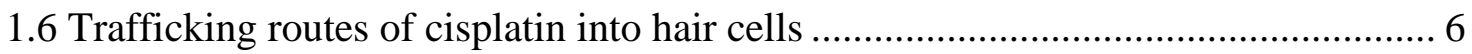

CHAPTER 2 DESIGN, SYNTHESIS AND CHARACTERIZATION OF

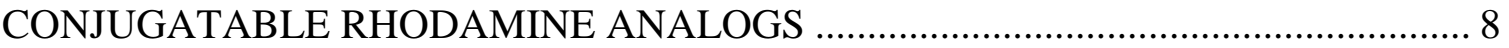

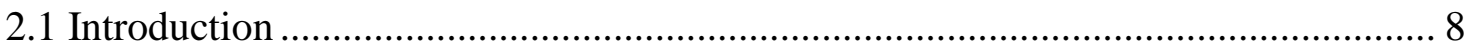

2.2 Molecular shape modifications of rhodamine analogs......................................... 9

2.3 Synthetic strategies of rhodamine analogs ............................................................. 13

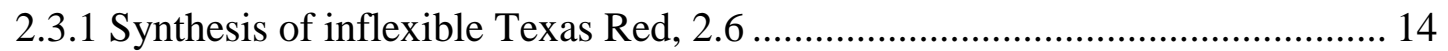

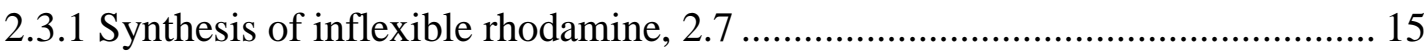




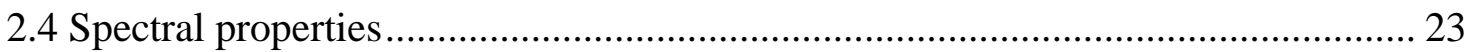

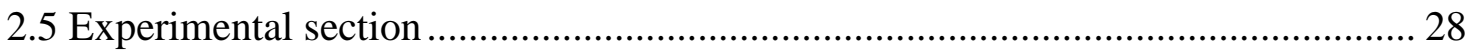

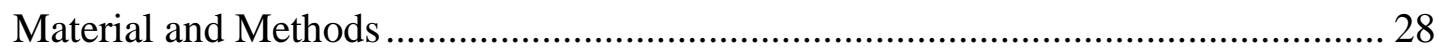

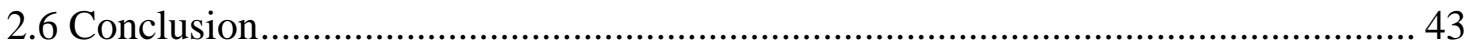

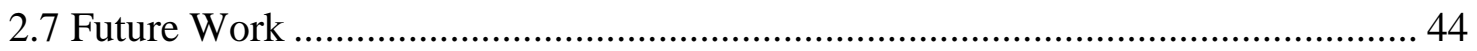

CHAPTER 3 THE UTILITY OF RIGID FLUOROPHORE-GENTAMICIN CONJUGATES IN ZEBRAFISH AND KIDNEY CELL TRAFFICKING STUDIES ... 45

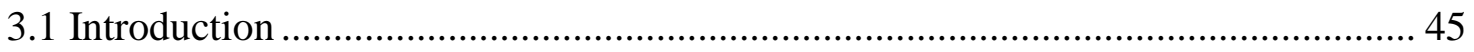

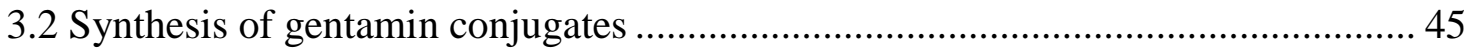

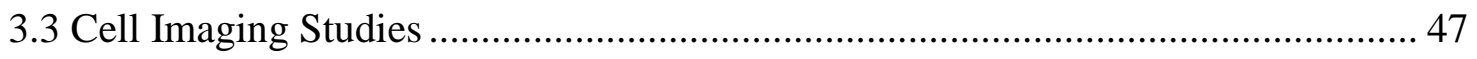

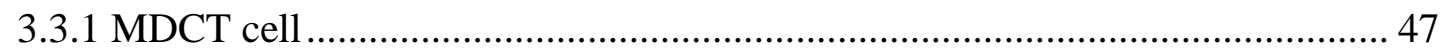

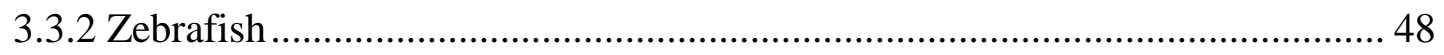

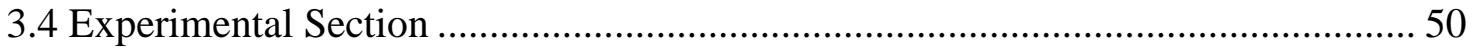

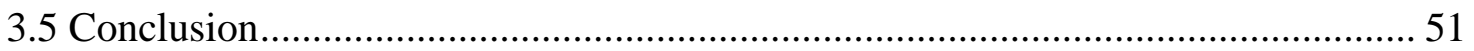

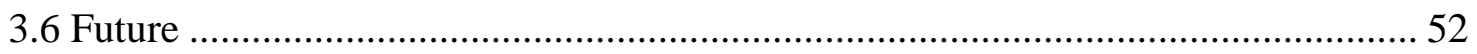

CHAPTER 4 SYNTHESIS OF A CISPLATIN-TEXAS RED CONJUGATE .............. 53

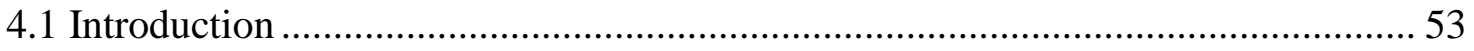

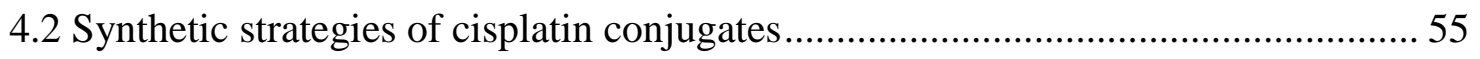


4.2.1 Synthesis of cisplatin-fluorescein conjugate, 4.2

4.2.2 Synthesis of cisplatin-Texas Red conjugste, 4.1 57

4.3 Spectral properties 60

4.4 Cellular studies 61

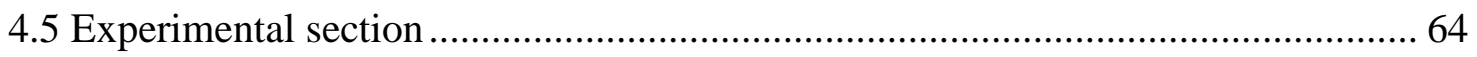

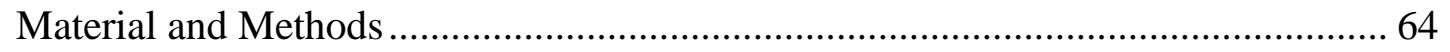

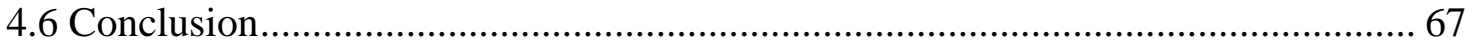

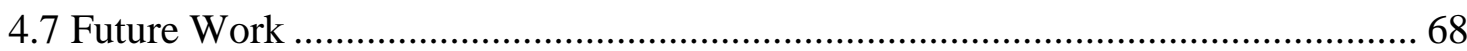

CHAPTER 5 SYNTHESIS OF A TETRAAMINO PLATINUM-TEXAS RED

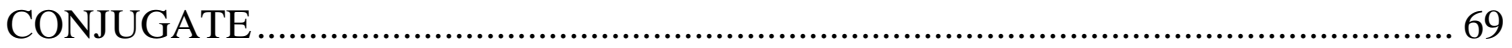

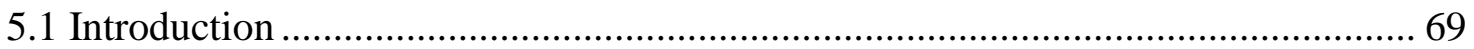

5.2 Synthesis of a tetra-amino platinum complex and its Texas Red Conjugate ......... 70

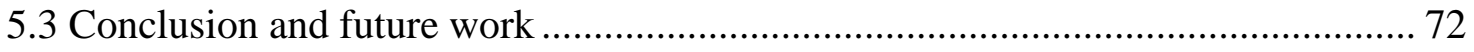

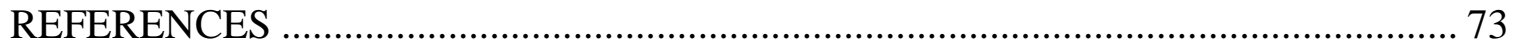

APPENDIX A: ${ }^{1} \mathrm{H}$ NMR, ${ }^{13} \mathrm{C}$ NMR AND $\mathrm{MS}$ SPECTRA FOR SELECTED

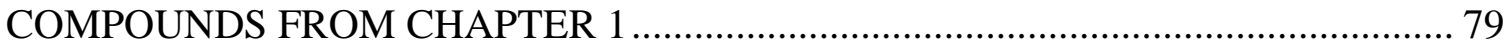

APPENDIX B: ${ }^{1} \mathrm{H}$ NMR, ${ }^{13} \mathrm{C}$ NMR, ${ }^{195} \mathrm{Pt}$ AND MS SPECTRA FOR SELECTED

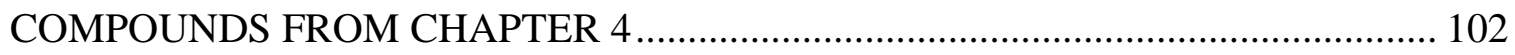




\section{LIST OF TABLES}

Table 2.1 Comparison of the fluorescence properties of compounds 2.2, 2.6, 2.7 and 2.8

.

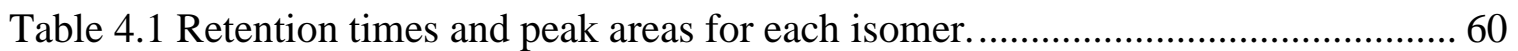




\section{LIST OF FIGURES}

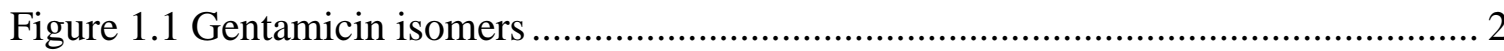

Figure 1.2 The mechanism of aminoglycoside binding to bacteria and the induction of cell death. Aminoglycosides bind to the 30s subunit of the ribosome causing misfolded proteins to be synthesized. Misfolded membrane proteins lead to enhanced drug uptake and cell death. The figure was adapted from Kohanski et al........................................... 3

Figure 1.3 Potential trafficking routes of gentamicin entering cochlea............................. 4

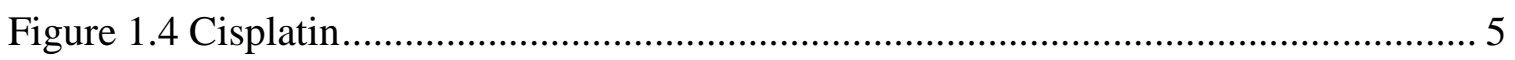

Figure 1.5 Aquation of cisplatin and insertion into DNA helical structure....................... 6

Figure 1.6 The trans-strial trafficking pathway for cisplatin from stria vascularis. …....... 7

Figure 2.1 Aminoglycosides labeling reagents and structures....................................... 9

Figure 2.2 Isomers of Gentamicin-Texas Red conjugate (GTTR, 2.1) and Texas Red succinimidyl ester (TR-SE, 2.2)......................................................................... 9

Figure 2.3 Phosphatidylinositol 4, 5-bisphosphate $\left(\mathrm{PIP}_{2}\right)$........................................... 10

Figure 2.4 Molecular simulations of 2.1, showing that the flexible linker promotes the interaction between fluorophore and gentamicin......................................................... 11

Figure 2.5 Molecular simulations of rhodamine analogs conjugated with gentamicin.... 13

Figure 2.6 Designed fluorophores for conjugation to gentamicin .................................. 14

Figure 2.7 Proposed Inflexible Texas-Red, 2.6 …………............................................. 14

Figure 2.8 Proposed extended inflexible rhodamine, 2.7 .............................................. 15

Figure 2.9 Designed extended-inflexible fluorophore with additional [1,2]-butano fused

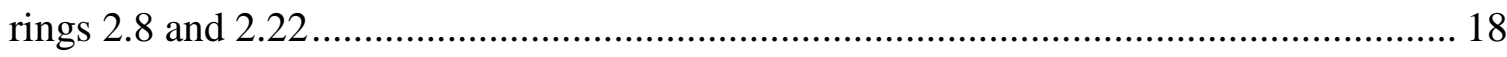




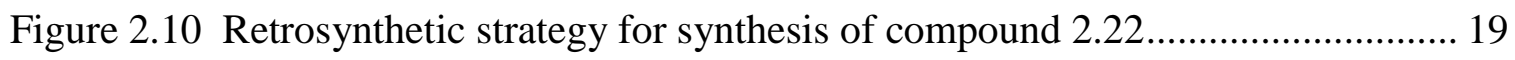

Figure 2.11 Retrosynthetic strategy for the synthesis of compound $2.8 \ldots \ldots \ldots \ldots \ldots \ldots \ldots \ldots . . . . . . . . . . .20$

Figure 2.12 An alternative retrosynthetic strategy for attaining compound $2.32 \ldots \ldots \ldots \ldots .22$

Figure 2.13 Absorption spectra of 2.2, 2.6, 2.7 and 2.8. Probe concentration: $1.25 \mu \mathrm{M}$.

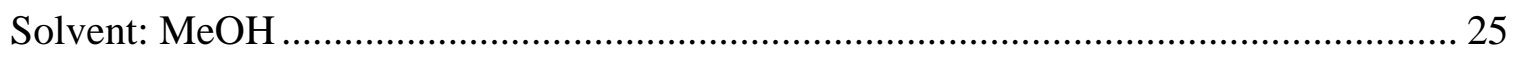

Figure 2.14 Normalized fluorescence excitation spectra of 2.2, 2.6, 2.7 and 2.8. Probe

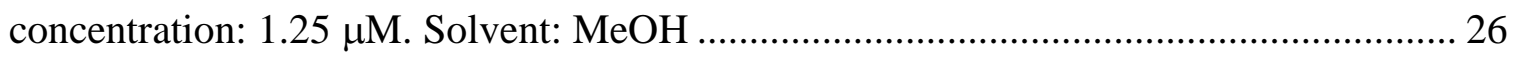

Figure 2.15 Normalized fluorescence emission spectra of 2.2, 2.6, 2.7 and 2.8. Probe

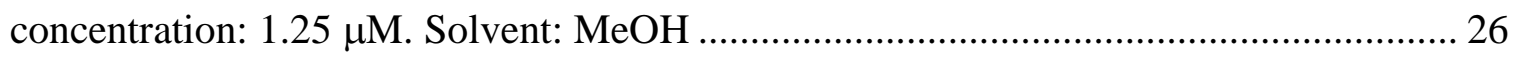

Figure 2.16 Absorption spectra of 2.2, 2.6, 2.7 and 2.8. Probe concentration: $1.25 \mu \mathrm{M}$.

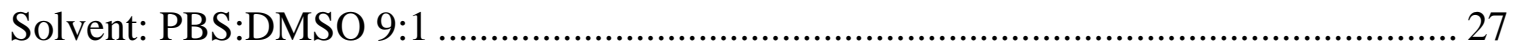

Figure 2.17 Normalized fluorescence excitation spectra of 2.2, 2.6, 2.7 and 2.8. Probe

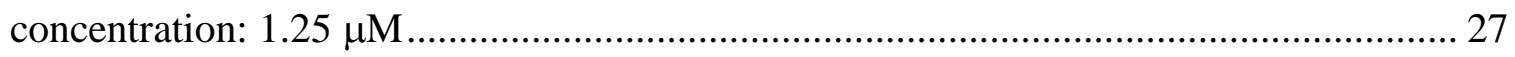

Figure 2.18 Normalized fluorescence emission spectra of 2.2, 2.6, 2.7 and 2.8. Probe concentration: $1.25 \mu \mathrm{M}$. Solvent: PBS:DMSO 9:1 .............................................. 28

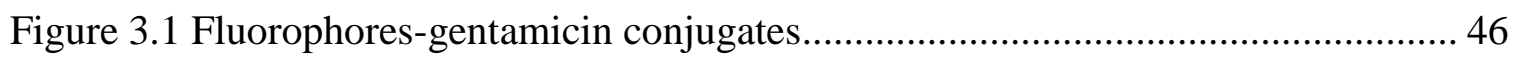

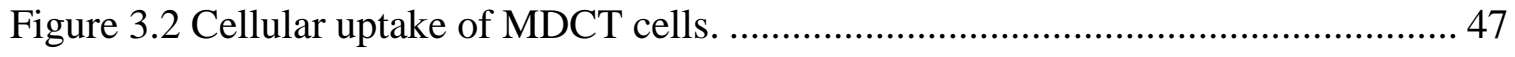

Figure 3.3 Cellular uptake with $1 \mu \mathrm{g} / \mathrm{ml}$ conjugates and free fluorophores by wild-type

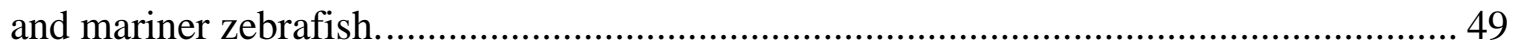

Figure 4.1 Fluorophores have been conjugated with cisplatin and its structure .............. 54

Figure 4.2 Isomers of Cisplatin-Texas Red conjugate, 4.1 and fluorescein conjugate, 4.2 
Figure 4.3 HPLC trace of compound 4.6 (isomer mixture)..................................... 57

Figure 4.4 HPLC trace of compound 4.2(isomer mixture) ..................................... 57

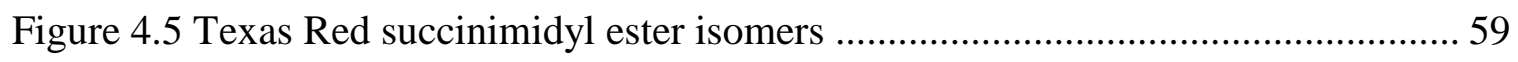

Figure 4.6 HPLC trace of compound 2.2 (isomer mixture) ..................................... 59

Figure 4.7 HPLC trace of compound 4.1 (isomer mixture) ...................................... 59

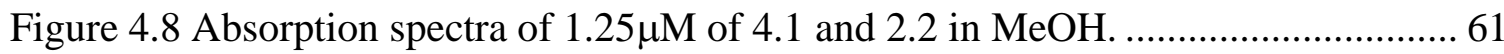

Figure 4.9 Excitation/Emission fluorescence spectra of $1.25 \mu \mathrm{M}$ of 4.1 and 2.2 in $\mathrm{MeOH}$.

Figure 4.10 Comparison of DDP-Fl (A) and DDP-TR (B) uptake by MDCK cells. ....... 62

Figure 4.11 Cytoxicity in zebrafish neuromast hair cells with a range of dose............... 63

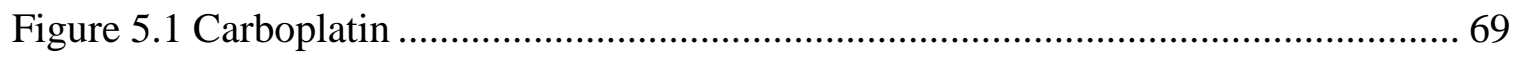

Figure 5.2 Amino platinum complex 5.1 and its proposed Texas Red conjugate 5.2 ..... 70 


\section{LIST OF ABBREVIATIONS}

\begin{tabular}{|c|c|}
\hline AcOH & Acetic Acid \\
\hline AGs & Aminoglycosides \\
\hline $\mathbf{a q}$ & aquesous \\
\hline Ar & Argon gas \\
\hline ATP7A & Copper transporting ATPase 1 \\
\hline Boc & tert-butyloxycarbonyl \\
\hline CFDA-SE & 5(6)-carboxyfluorescein diacetate succinimidyl ester \\
\hline $\mathrm{CH}_{2} \mathrm{Cl}_{2}$ & Dichloromethane \\
\hline Ctr1 & Copper transporter-1 \\
\hline DCE & Dichloroethane \\
\hline DDP-Fl & Cisplatin-fluorescein conjugate \\
\hline DDP-TR & Cisplatin-Texas Red conjugate \\
\hline DI & Deionized \\
\hline DMF & N,N-dimethylformamide \\
\hline DMSO & Dimethylsulfoxide \\
\hline DNA & Deoxyribonucleic acid \\
\hline EDAC & 1-Ethyl-3-(3-dimethylaminopropyl) carbodiimide \\
\hline Equiv & Equivalents \\
\hline ESI MS & Electrospray ionization mass spectrum \\
\hline $\mathbf{E t}_{2} \mathbf{O}$ & Ethyl ether \\
\hline $\mathbf{E t}_{\mathbf{3}} \mathbf{N}$ & Triethylamine \\
\hline
\end{tabular}




\begin{tabular}{|c|c|}
\hline EtOAc & Ethyl acetate \\
\hline GTTR & Gentamicin Texas Red conjugate \\
\hline $\mathbf{h}$ & hour \\
\hline $\mathrm{HBr}$ & Hydrobromic acid \\
\hline $\mathrm{HCl}$ & Hydrochloric acid \\
\hline HPLC & High performance liquid chomatography \\
\hline iTR & Inflexible Texas Red \\
\hline КОН & Potassium hydroxide \\
\hline LC/MS & Liquid chromatography-mass spectrometry \\
\hline $\mathrm{LiAlH}_{4}$ & Lithium aluminium hydride \\
\hline MDCK & Madin-Darby Canine Kidney \\
\hline MDCT & Mouse Distal Convoluted Tubule \\
\hline $\mathrm{MeCN}$ & Acetonitrile \\
\hline MeI & Methyl iodide \\
\hline МeOH & Methanol \\
\hline MET & Mechanoelectrical \\
\hline $\min$ & minutes \\
\hline MS & Mass Spectrometry \\
\hline $\mathrm{NaBH}(\mathrm{OAc})_{3}$ & Sodium triacetoxyborohydride \\
\hline $\mathrm{NaBH}_{4}$ & Sodium borohydride \\
\hline NHS & $N$-Hydroxy succinimide \\
\hline NMR & Nuclear magnetic resonance \\
\hline
\end{tabular}




\begin{tabular}{|c|c|}
\hline Oct2 & Organic cation transporter 2 \\
\hline $\mathbf{P B r}_{3}$ & Phosphorus tribromide \\
\hline PBS & Phosphate-buffered saline \\
\hline $\mathbf{P I P}_{2}$ & Phosphatidylinositol 4, 5-bisphosphate \\
\hline PLs & Phospholipids \\
\hline PPA & Polyphosphoric acid \\
\hline RNA & Ribonucleic acid \\
\hline ROS & Reactive oxygen species \\
\hline $\mathbf{r t}$ & Room temperature \\
\hline $\mathbf{S}$ & seconds \\
\hline $\mathbf{S N}_{2}$ & Second-order Nucleophilic Substitution \\
\hline TFA & Trifluoroacetic acid \\
\hline THF & Tetrahydrofuran \\
\hline TMS & Tetramethylsilane \\
\hline TRPV1 & Transient receptor potential cation channel subfamily V member 1 \\
\hline TRPV4 & Transient receptor potential cation channel subfamily $\mathrm{V}$ member 4 \\
\hline TR-SE & Texas Red succinimidyl ester \\
\hline UV-Vis & Ultraviolet-visible \\
\hline $\mathbf{Z n}$ & Zinc \\
\hline
\end{tabular}




\section{CHAPTER 1 INTRODUCTION}

Most medications, regardless of whether they are of the over-the-counter or prescription variety, exhibit a certain level of undesirable and sometimes life-threatening side-effects. Two examples of widely-prescribed drugs that cause profound side effects in extremely high percentages of the patients using them are gentamicin and cisplatin. Although they possess very dissimilar structures and treat different diseases, each causes acute renal dysfunction and irreversible hearing loss.

\subsection{Gentamicin}

Gentamicin, a major aminoglycoside antibiotic naturally produced by Micromonospora, is composed of three major isomeric components $\mathrm{C}_{1}, \mathrm{C}_{1 \mathrm{a}}$ and $\mathrm{C}_{2}$, as shown in Figure 1.1. It is used in the treatment of gram-negative infections such as tuberculosis, ${ }^{1}$ meningitis, ${ }^{2}$ cystic fibrosis, ${ }^{3}$ and in the prevention of sepsis infections in burn patients ${ }^{4}$ and premature babies. ${ }^{5}$ However, irreversible ototoxicity and acute nephrotoxicity are serious side effects in patients. Every year $>600,000$ new-born babies receive gentamicin for a diagnosis of potential sepsis. ${ }^{5}$ Over $10 \%$ of all patients that receive aminoglycoside antibiotics suffer from drug-induced hearing loss. ${ }^{6}$ The lifetime opportunity cost for hearing impairment was estimated at $\$ 1$ million in 2000 for each prelingual deaf child. ${ }^{7}$ Approximately $14 \%$ of all patients receiving gentamicin treatment also experience acute loss of kidney function. ${ }^{6}$ Despite these risks, gentamicin is a clinically-essential antibiotic due to its high bactericidal efficacy and low cost. $^{8}$ 


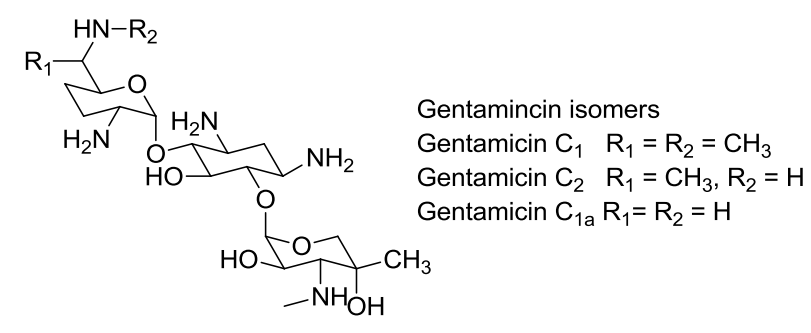

Figure 1.1 Gentamicin isomers

\subsection{Bactericidal mechanism of gentamicin}

Aminoglycosides (AGs) such as gentamicin irreversibly bind to the 30s subunit of the bacterial ribosome responsible for protein synthesis. Binding triggers a cascade of events leading to cell death, beginning with altered protein biosynthesis, due to the misincorporation of amino acids into elongating peptides. The resulting proteins are often misfolded and dysfunctional. When incorporated into the cytoplasmic membrane, misfolded proteins enhance the permeability of the cell membrane, thereby further enhancing gentamicin uptake and toxicity. Mistranslated bacterial membrane proteins additionally disrupt the signaling mechanism that counteracts the cytotoxicity of AGs as well as $\beta$-lactam antibiotics, leading to the synergistic bactericidal efficacy of the two compounds. ${ }^{9}$ 


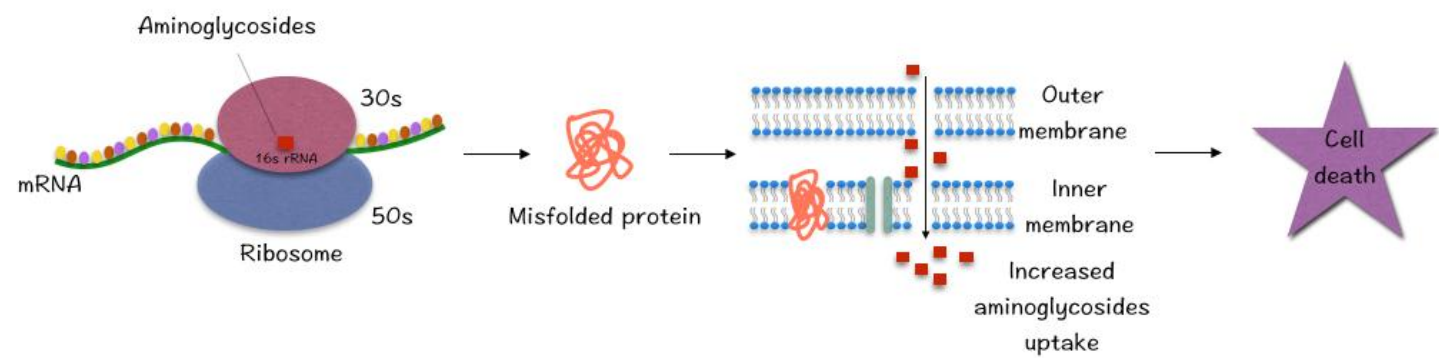

Figure 1.2 The mechanism of aminoglycoside binding to bacteria and the induction of cell death. Aminoglycosides bind to the 30s subunit of the ribosome causing misfolded proteins to be synthesized. Misfolded membrane proteins lead to enhanced drug uptake and cell death. The figure was adapted from Kohanski et al. ${ }^{9}$

\subsection{Trafficking routes of gentamicin into the cochlea associated with deafness}

Many studies have focused on the intracellular mechanisms of unwanted sideeffects of AGs in the kidney and cochlear sensory hair cells in the inner ear. However, the precise route of drug trafficking from the vasculature across the blood-labyrinth barrier and into sensory hair cells in the inner ear is still not completely understood. Aminoglycosides could enter hair cells via various mechanisms (Figure 1.3, route 1) including apical endocytosis ${ }^{10-12}$ and via ion channels such as the mechanoelectrical (MET) transduction channel ${ }^{13}$ on the apical surface of the cochlear hair cells. This indicates that the most viable route for systemically-administered AGs in vivo is believed to take place via passage from the strial capillaries into the endolymph (trans-strial trafficking mechanism) prior to entering hair cells through MET channels, as shown in Figure 1.3, route $2 .^{13,14}$ There are potential alternative trafficking pathways that AGs could take prior to entering hair cells, such as via capillaries in the spiral ligament of the 
lateral wall into the perilymph of the scala tympani and across the baso-lateral membrane of hair cells. (Figure 1.3, route 3 and 4).

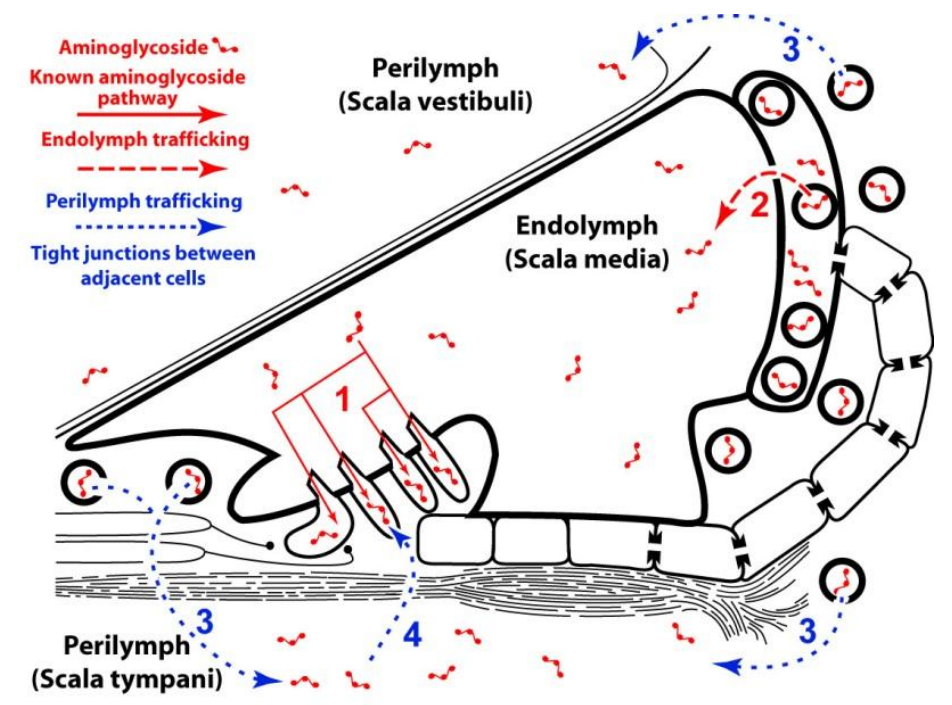

Figure 1.3 Potential trafficking routes of gentamicin entering cochlea.

(Route 1) Aminoglycosides are known to enter hair cells via apical endocytosis or permeation of the MET channels on the apical surface of hair cells. (Route 2) AGs could enter the endolymph via a trans-strial trafficking route from stria capillaries to marginal cells, or (Route 3) by traversing the blood labyrinth barrier into perilymph and then (Route 4) into hair cells across their baso-lateral membranes (diagram not to scale). This figure was adapted from Wang et al. ${ }^{15}$

\subsection{Cisplatin}

Cisplatin (cis-diamminedichloroplatinum[II]) is a platinum-containing anti-cancer drug, whose bioactivity was discovered by Rosenberg et al. in $1965 .{ }^{16}$ Since then, cisplatin has become a cornerstone of antineoplastic chemotherapy to treat many types of cancer, including ovarian, cervical, stomach, bladder, head and neck. ${ }^{17-19}$ Cisplatin is especially efficacious for testicular cancer, wherein over $90 \%$ of cases enter remission 
after treatment. ${ }^{20}$ Every year more than one million patients receive cisplatin or its derivatives in North America and Europe. Unfortunately, the clinical use of cisplatin is limited by acquired drug resistance and severe dose-dependent side effects, such as ototoxicity and nephrotoxicity (similar to gentamicin, above). Clinical studies show that $>60 \%$ of patients taking multiple doses of cisplatin will develop permanent hearing $\operatorname{loss}^{21,22}$ and acute renal dysfunction. ${ }^{23}$ Drug-induced hearing loss can severely affect an individual's quality of life. Consequences can include social isolation, depression and loss of income. Children can exhibit delayed development of communication and learning skills, and have a relatively challenging time developing social interactions. ${ }^{21,22}$ Therefore, an understanding of the fundamental biological mechanisms that lead to cisplatin-induced ototoxicity and nephrotoxicity can have a profound impact on patients' lives, especially if it can inform the development of less harmful therapeutic options, or the development of otoprotective strategies.

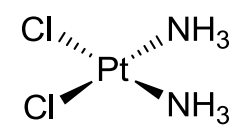

Figure 1.4 Cisplatin

\subsection{Mechanism of action of Cisplatin}

During chemotherapy, cisplatin binds to DNA, disrupting genetic function and selectively killing rapidly proliferating cells such as cancer cells. The underlying mechanism involves ligand exchange within the cells of cisplatin's chlorides for $\mathrm{H}_{2} \mathrm{O}$, in a process called aquation. These charged aquated complexes are highly reactive and bind 
to the $\mathrm{N}^{7}$ position of purines on DNA, forming cisplatin-DNA adducts, distorting the helical structure of DNA (Figure 1.5). ${ }^{24}$ Cells identify this as damaged DNA, activating several signaling cascades that induce cell cycle arrest and apoptosis. ${ }^{25}$

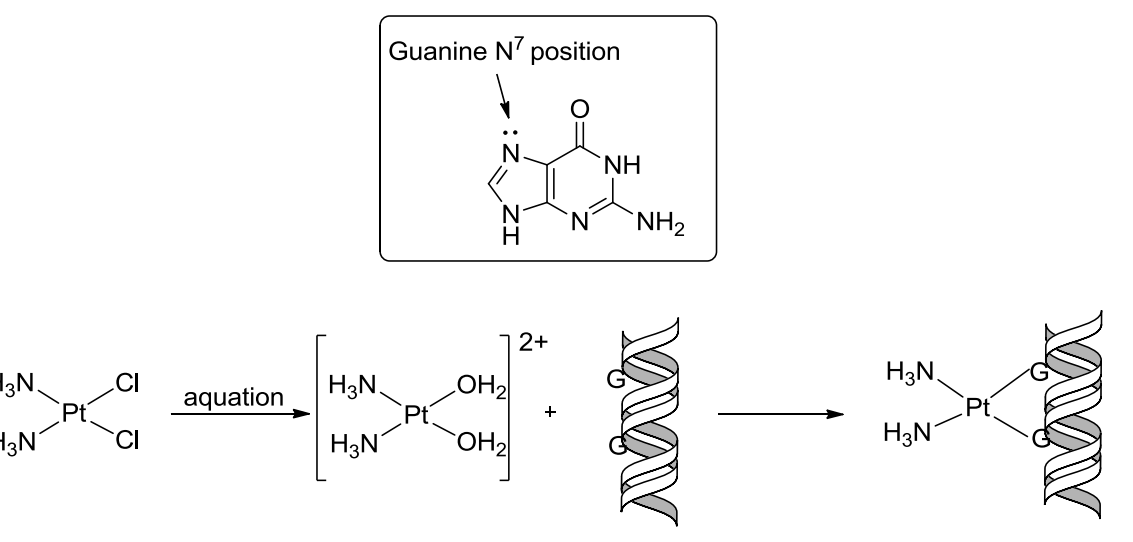

Figure 1.5 Aquation of cisplatin and insertion into DNA helical structure.

Oxidative stress is thought to be another major mechanism of cisplatin-induced ototoxicity and nephrotoxicity. ${ }^{26}$ Once cisplatin enters cells, the charged aquatedplatinum complex rapidly interacts with thiol-containing antioxidant molecules such as glutathione and methionine. ${ }^{27}$ The depletion of antioxidants leads to cytotoxic levels of reactive oxygen species (ROS) and lipid peroxidation product accumulation in cells. Other mechanisms whereby cisplatin promotes elevated levels of ROS are via the respiratory chain ${ }^{28}$ and the cytochrome P450 (CYP) system ${ }^{29}$.

\subsection{Trafficking routes of cisplatin into hair cells}

As shown in Figure 1.6, cisplatin has an uptake route into cochlear hair cells analogous to that described above for gentamicin, entering the endolymph via a trans- 
strial trafficking route from stria vascularis (route 2). To date, several studies have shown that one or several candidate membrane transporters potentially play an important role in cisplatin uptake and efflux pathways to induce cytotoxicity, and cochleotoxicity (hearing loss). These include the copper transporters (Ctr1 and ATP7A) and the organic cation transporter (Oct2) ${ }^{30-32}$ Ciarimboli et al. ${ }^{33}$ using a Oct2 inhibitor, cimetidine, and More et $a l .{ }^{34}$ using the competitive inhibitor, $\mathrm{CuSO}_{4}$, have observed protection from cisplatininducing hearing loss in vivo, as further evidence of the involvement of Oct2 and Ctr1 in cisplatin uptake into healthy cells. However, results reported by Thomas et al. using a rhodamine-cisplatin conjugate showed that MET channel function is required for cisplatin-induced hair cell cytotoxicity, while Crt1 and Oct2 are not involved in the cisplatin uptake mechanism. ${ }^{35}$ In other words, there is a significant current need to clarify the mechanism of cisplatin entry into cochlear hair cells.

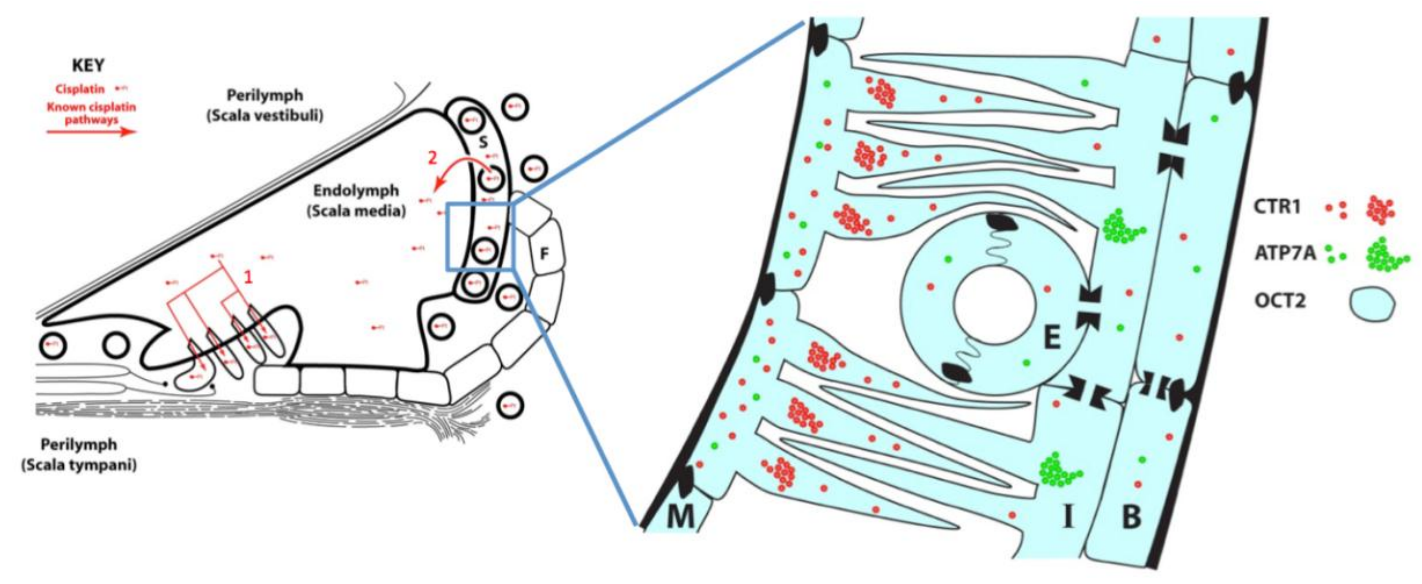

Figure 1.6 The trans-strial trafficking pathway for cisplatin from stria vascularis.

The candidate cisplatin transporters are located on the strial capillaries including Oct2, Ctr1 and ATP7A (M, marginal cell; I, intermediate cell; B, basal cell; E, endothelial cell) (diagram not to scale). 


\section{CHAPTER 2 DESIGN, SYNTHESIS AND CHARACTERIZATION OF CONJUGATABLE RHODAMINE ANALOGS}

\subsection{Introduction}

Fluorescent probes are widely used for the detection of specific biomolecular pathways and cellular events. The objective of this study is to synthesize rigid, geometrically well-defined rhodamine derivatives to serve as the optical components of cationic drug-fluorophore conjugates. The long-term goal is to use these drugfluorophore conjugates to determine the dimensions of ion channels involved in the cellular uptake of pharmaceuticals such as gentamicin. This is significant because new information on cellular trafficking can shed light on the mechanism, and potential prevention of side effects such as ototoxicity and nephrotoxicity.

Fluorescein, BODIPY and acridine dyes (Figure 2.1) have been conjugated to aminoglycosides such as gentamicin and neomycin to study cellular uptake, ${ }^{36,37} \mathrm{HIV}$ RNA binding ${ }^{38}$ and for use in fluorescent immunoassays. ${ }^{39}$ The fluorescent conjugate of gentamicin and Texas Red (GTTR, 2.1) has been of great utility in the study of nonendocytotic aminoglycoside uptake and intracellular localization (Figure 2.2). ${ }^{40,41}$ Texas Red succinimidyl ester (TR-SE, 2.2) is the fluorophore used for gentamicin conjugation because it imparts amphiphilic properties, cationic charge and enables the retention of drug bioactivity. ${ }^{42-44}$ 


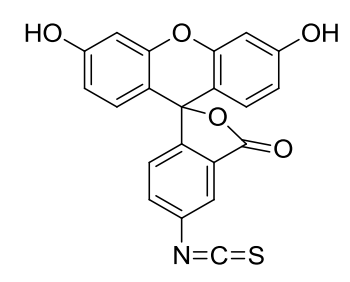

fluorescein isothiocyanate

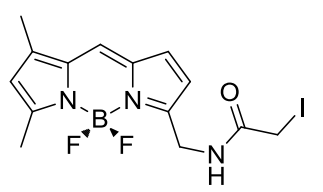

BODIPY C1-IA

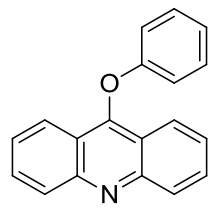

9-phenoxyacridine

Figure 2.1 Aminoglycosides labeling reagents and structures
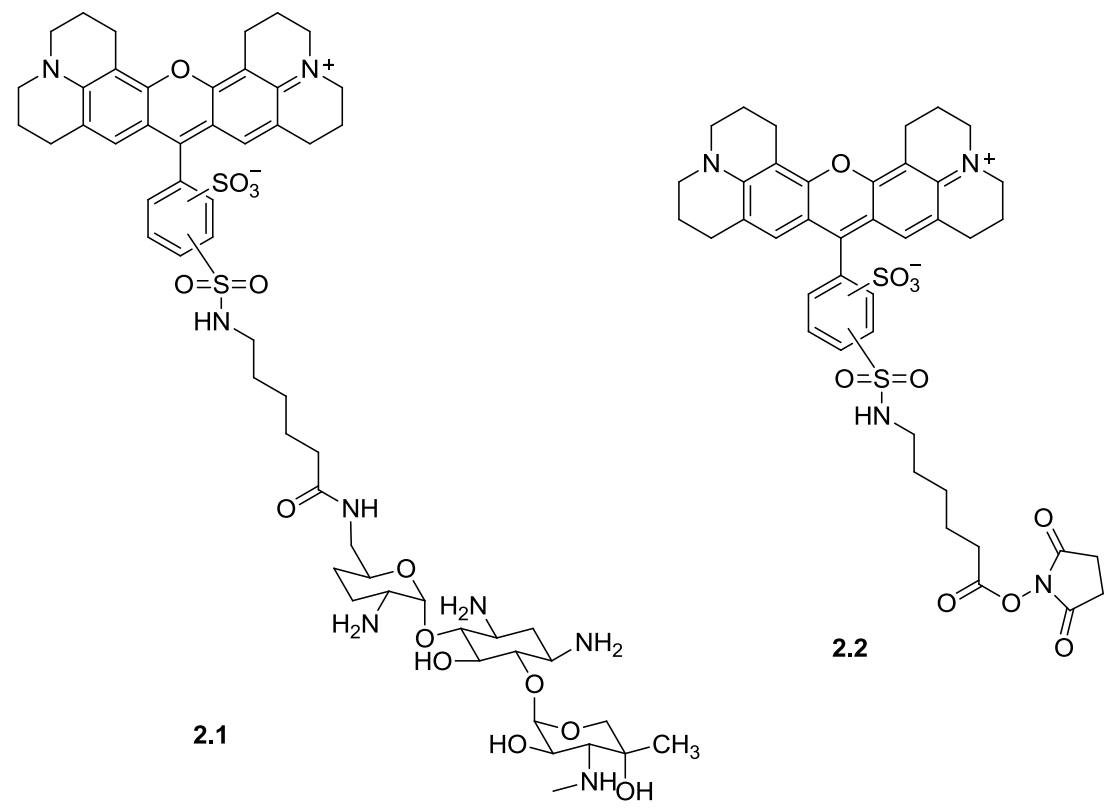

Figure 2.2 Isomers of Gentamicin-Texas Red conjugate (GTTR, 2.1) and Texas Red succinimidyl ester (TR-SE, 2.2)

\subsection{Molecular shape modifications of rhodamine analogs}

GTTR in vivo studies have been mainly performed in fixed cells since live cells quench GTTR fluorescence. ${ }^{40}$ This fluorescence quenching has been attributed in part to the interactions between gentamicin and phospholipids. It has been reported that cationic 
aminoglycosides have high affinity for the anionic phospholipid phosphatidylinositol 4, 5-bisphosphate $\left(\mathrm{PIP}_{2}\right.$, Figure 2.3). ${ }^{45,46}$ GTTR fluorescence quenching in cells was determined by Myrdal et al. Results from these studies indicate that gentamicin binding to $\mathrm{PIP}_{2}$ and similar phospholipids (PLs) is likely responsible for quenching GTTR fluorescence in live cells and that this quenching can be unmasked by delipidating cells using either Triton-X 100 or similar delipidating agents. ${ }^{40}$

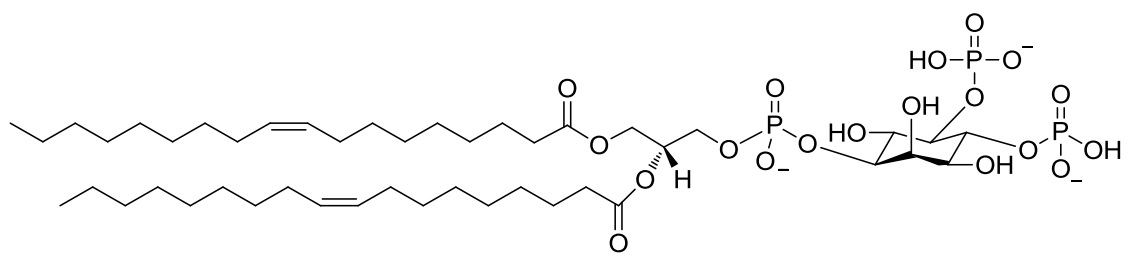

Figure 2.3 Phosphatidylinositol 4, 5-bisphosphate $\left(\mathrm{PIP}_{2}\right)$

Molecular modeling was used to guide the design of new fluorophores for conjugation to gentamicin to allow the study of gentamicin cellular uptake trafficking in live and fixed cells. Simulations showed that the current GTTR conjugate, 2.1 used in preliminary studies, has a sulfonated-flexible linker between the gentamicin and Texas Red moieties that promotes folding of the structure and interactions between the fluorophore and gentamicin. (Figure 2.4) 


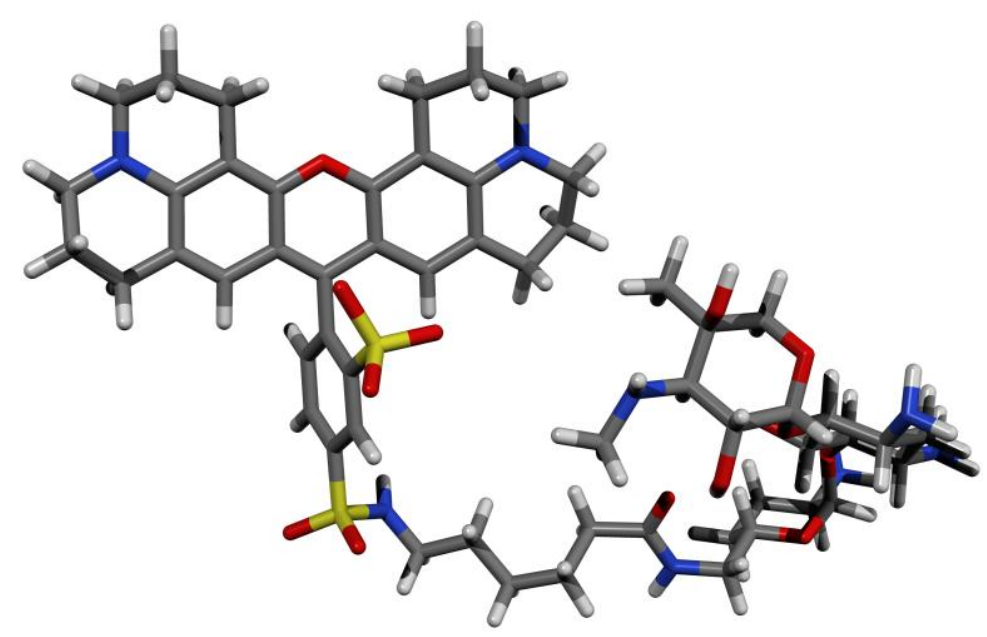

Figure 2.4 Molecular simulations of 2.1, showing that the flexible linker promotes the interaction between fluorophore and gentamicin

Also, the energy-minimized structure of stretched conformer of GTTR (Figure 2.5A) has a maximal cross-sectional diameter of $1.35 \mathrm{~nm}$, and can pass through cationselective channels on hair cell stereocilia, such as MET channels, ${ }^{13}$ TRPV1 ${ }^{47}$ and TRPV4, ${ }^{48}$ likely through pore dilation. ${ }^{49}$ MET channels have a minimum pore size of $1.25 \mathrm{~nm}^{50}$; TRPV1 channels have an open pore size of $\sim 1 \mathrm{~nm}^{51,52}$ that increases following agonist-induced pore dilation, ${ }^{49,53}$ TRPV4 channels have a larger pore diameter ${ }^{54}$ that allows organic cation permeation upon agonist-induced activation. ${ }^{55}$

Because of the correlation between the molecular simulations and the results of preliminary studies using the current gentamicin conjugate 2.1, it is hypothesized that rigidifying the linker will avoid potential intramolecular interactions between the fluorophore and gentamicin, and thereby inhibit fluorescence quenching. In addition, the 
incorporation of a rigid liker will prevent conjugate bending as a means of passing through ion channels, and thus act as a molecular ruler of channel pore diameter.

In order to test the hypothesis that systematic molecular shape modifications of the fluorophore and linker can afford control over hair cell and kidney cell gentamicin uptake and toxicity, a series of inflexible rhodamine analogs were designed and synthesized. Molecular simulations show that a biaryl linker (2.3, Figure 2.5B) meets the requirement to prevent intramolecular interactions between the fluorophore and the gentamicin moieties, and possesses a cross-sectional diameter of $1.44 \mathrm{~nm}$. The crosssectional diameter of the final conjugate can be increased to $1.56 \mathrm{~nm}$ by adding four methyl groups to the fluorophore scaffold (2.4, Figure 2.5C). Additional [1,2]-butano fused rings on the fluorophore framework furnishes a conjugate with a cross-sectional diameter of $1.85 \mathrm{~nm}(\mathbf{2 . 5}$, Figure 2.5D). The design of these rigid probes allow them to be used as molecular rulers, to aid us in determining the maximum diameter of dilated AGpermissive ion channels, such as MET channel and TRPV1. 
A
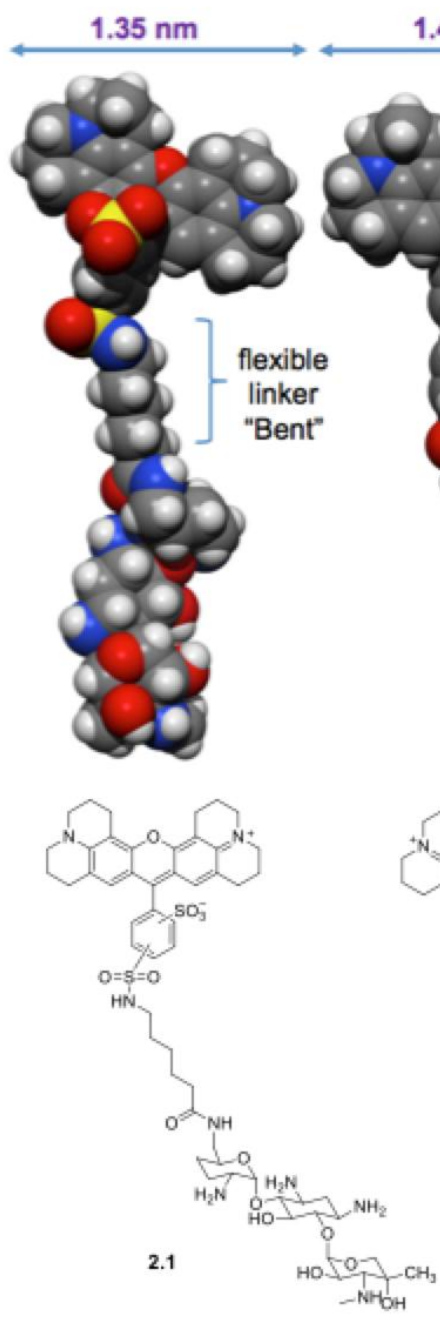

B
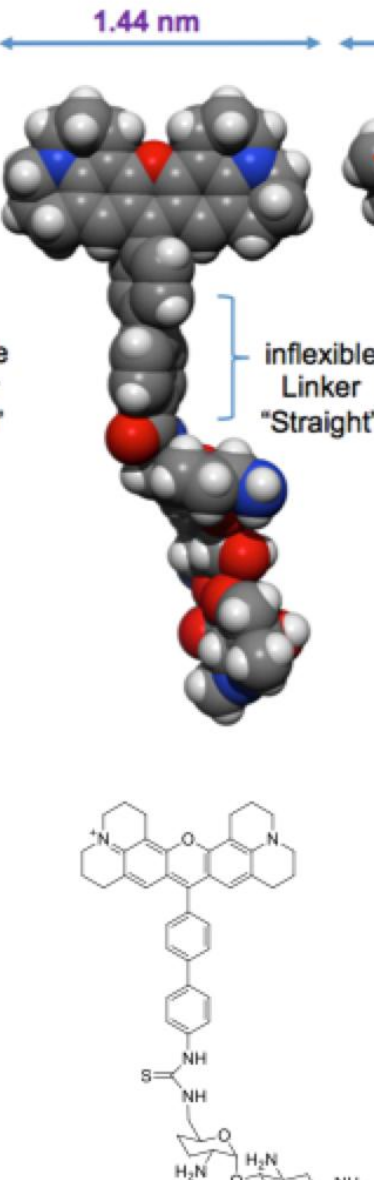

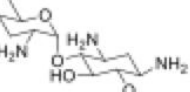

2.3
C $1.56 \mathrm{~nm}$
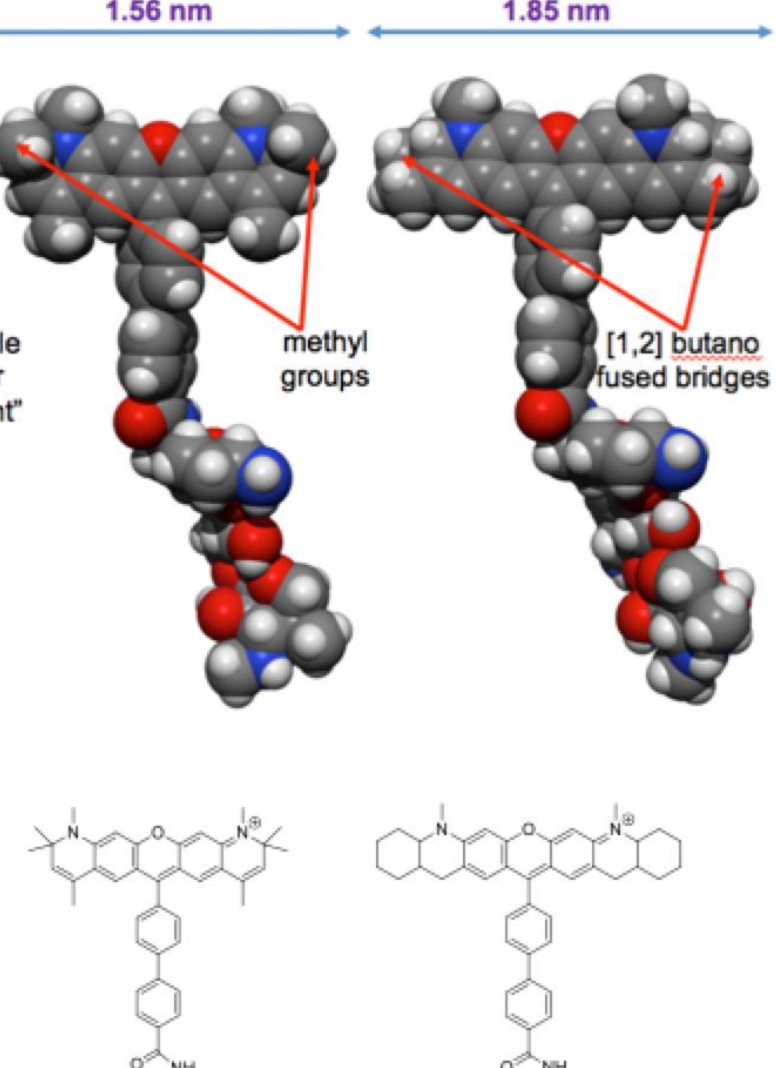

(

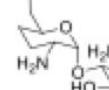

N-

2.4

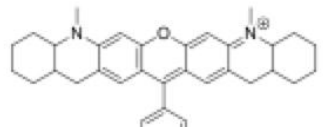

ह

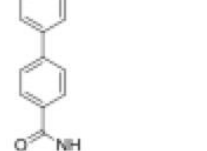

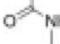

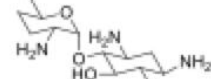

2.5

Figure 2.5 Molecular simulations of rhodamine analogs conjugated with gentamicin.

(A) Flexible GTTR, yellow atoms represent sulfur atoms. (B) Sulfur atoms are replaced by para-phenyl rings, to give inflexible conjugates. $(\mathrm{C}, \mathrm{D})$ Adding methyl groups or $[1,2]$-butano fused rings increases the diameter of the conjugate.

\subsection{Synthetic strategies of rhodamine analogs}

Figure 2.6 shows the three fluorophore structures that were proposed from the simulations. The figure shows the inflexible biaryl linkers of each, as well as the extended cross-sectional diameter of the fluorophore. 

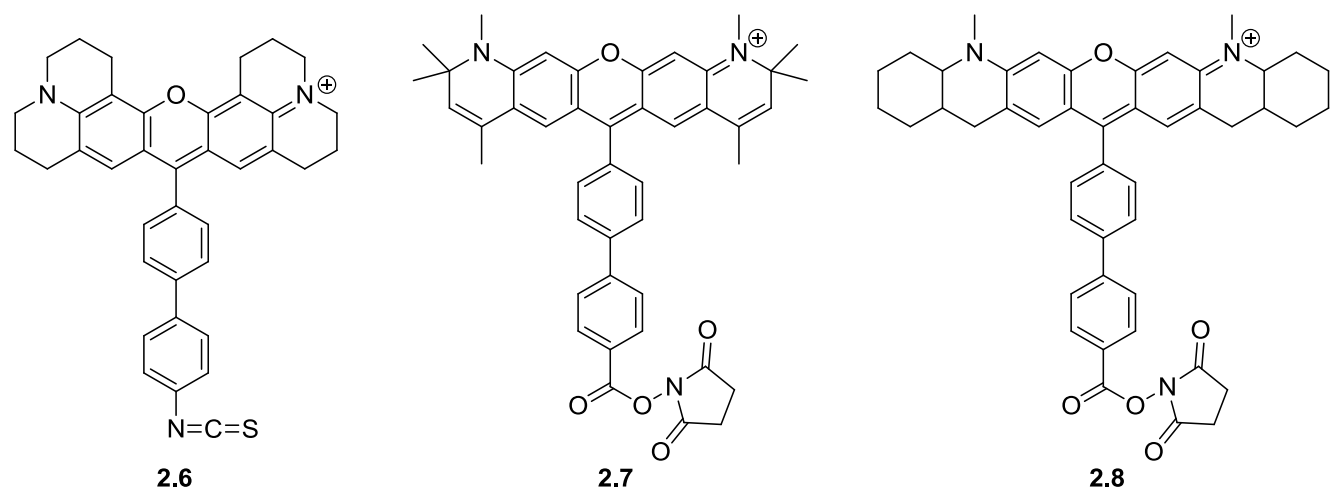

Figure 2.6 Designed fluorophores for conjugation to gentamicin

\subsubsection{Synthesis of inflexible Texas Red, 2.6}

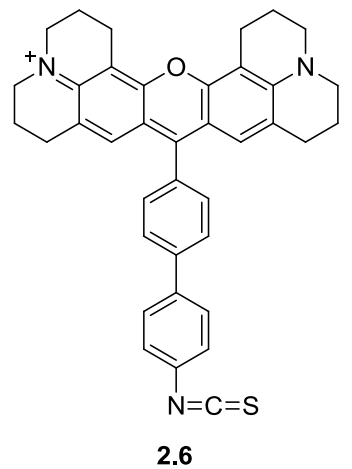

Figure 2.7 Proposed Inflexible Texas-Red, 2.6

Based on the molecular simulation results, inflexible Texas Red analog $\mathbf{2 . 6}$ possesses a diameter of $1.44 \mathrm{~nm}$. As shown in scheme 2.1, compound 2.6 was synthesized in four steps with an overall yield of 13\%. The initial step involves the condensation of 8-hydroxyjulolidine $\mathbf{2 . 9}$ and 4-bromobenzaldehyde $\mathbf{2 . 1 0}$ under microwave conditions followed by addition of $p$-chloranil as an oxidant to give bromosubstituted rhodamine $\mathbf{2 . 1 1}$ in $47 \%{ }^{56}$ Suzuki-coupling of $\mathbf{2 . 1 1}$ with 4 -(N-Boc-amino) phenylboronic acid was carried out in the presence of $\mathrm{K}_{2} \mathrm{CO}_{3}$ in $\mathrm{MeOH}$, heated at reflux 
overnight to afford Boc-protected amino biphenyl Texas-Red $\mathbf{2 . 1 2}$ in $45 \%$. Removal of the Boc group using trifluoroacetic acid gave the free amine $\mathbf{2 . 1 3},{ }^{57}$ which was reacted with $1,1^{\prime}$-thiocarbonyldi-2(1H)- pyridine to afford $\mathbf{2 . 6}$ in $71 \%$ yield. $^{58}$

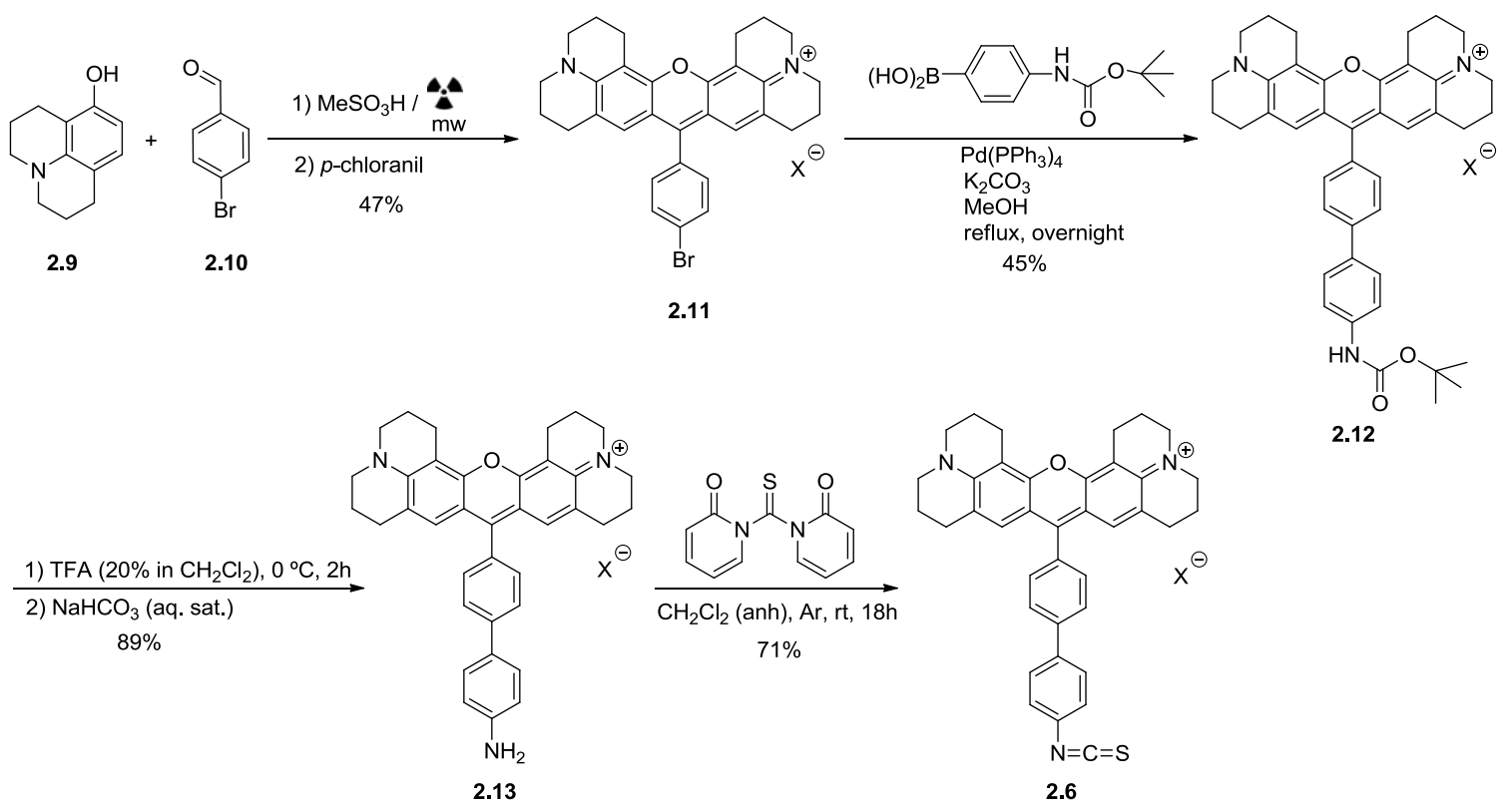

Scheme 2.1 Synthesis of inflexible Texas Red, 2.6

\subsubsection{Synthesis of inflexible rhodamine, 2.7}

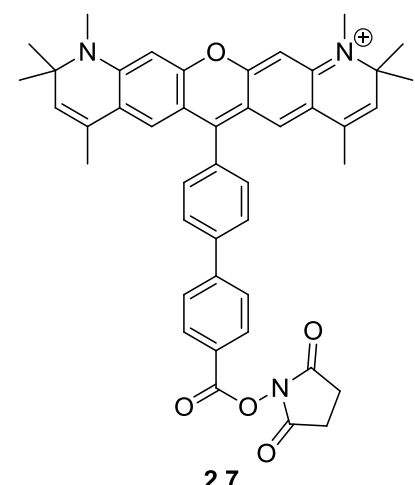

Figure 2.8 Proposed extended inflexible rhodamine, 2.7 
Rhodamine $\mathbf{2 . 7}$ possesses four methyl groups on the fluorophore scaffold resulting in a diameter of $1.56 \mathrm{~nm}$. As shown in scheme 2.2, the required hydroxylquinoline 2.17 was synthesized using a modified procedure as described by Belov et al. ${ }^{59}$ Trimethyl-dihydroquinoline amine $\mathbf{2 . 1 5}$ was obtained in $80 \%$ yield by condensation of $\mathrm{m}$ anisidine with acetone at $\mathrm{rt}$ for $24 \mathrm{~h}$ using ytterbium triflate as the catalyst. Further alkylation of $\mathbf{2 . 1 5}$ with methyl iodide in the presence of cesium carbonate gave the tetramethyl-dihydroquinoline $\mathbf{2 . 1 6}$ in $89 \%$ yield. Nucleophilic dealkylation of intermediate $\mathbf{2 . 1 6}$ with $48 \%$ aq. $\mathrm{HBr}$ in acetic acid gave the corresponding hydroxylquinoline $\mathbf{2 . 1 7}$ in $54 \%$ yield.

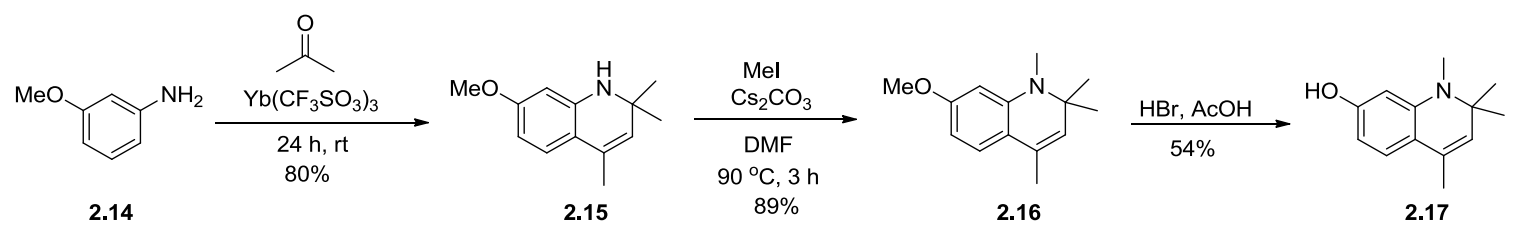

Scheme 2.2 Synthesis of hydroxyl-quinoline precursor $\mathbf{2 . 1 7}$

As shown in scheme 2.3, initial attempts (Route 1) to prepare the succinimidyl activated ester 2.7 involved the synthesis of the bromo-substituted rhodamine $\mathbf{2 . 1 8}$ published by Jiao et $a .^{56}$ followed by a Suzuki coupling reaction with (4(methoxycarbonyl)phenyl)boronic acid. ${ }^{60}$ After extensive optimization, the Suzuki coupling reaction of bromo-substituted rhodamine with boronic acid gave precursor 2.19; however, the reaction was sluggish (it required five days) and gave rise to mixtures hard to separate. Therefore, an alternative approach (Route 2) involving the direct condensation of the hydroxyl-quinoline $\mathbf{2 . 1 7}$ and methyl 4-(4-formylphenyl)benzoate 2.20 was evaluated. The methyl ester precursor $\mathbf{2 . 1 9}$ was obtained in $67 \%$ yield by 
condensation of hydroxy-quinoline $\mathbf{2 . 1 7}$ and methyl 4-(4-formylphenyl)benzoate $\mathbf{2 . 2 0}$ under microwave conditions in the absence of solvent at $150{ }^{\circ} \mathrm{C}$ followed by oxidation with $p$-chloranil. The hydrolysis of methyl ester intermediate $\mathbf{2 . 1 9}$ was conducted under basic conditions using $\mathrm{LiOH}$ in a mixture of $\mathrm{MeOH}: \mathrm{THF}^{\mathrm{H}} \mathrm{H}_{2} \mathrm{O}$ (5:3:1) to give compound 2.21 in 78\%. The activated succinimidyl ester $\mathbf{2 . 7}$ was achieved in $84 \%$ yield using EDAC as the coupling reagent. The target fluorophore $\mathbf{2 . 7}$ was synthesized in six steps with an overall yield of $17 \%$.

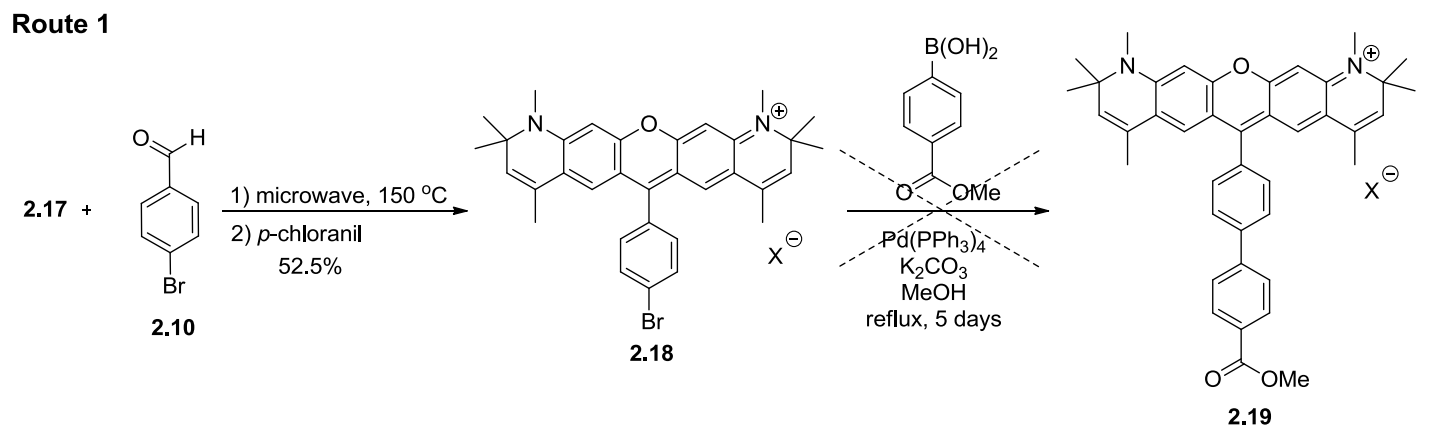

Route 2
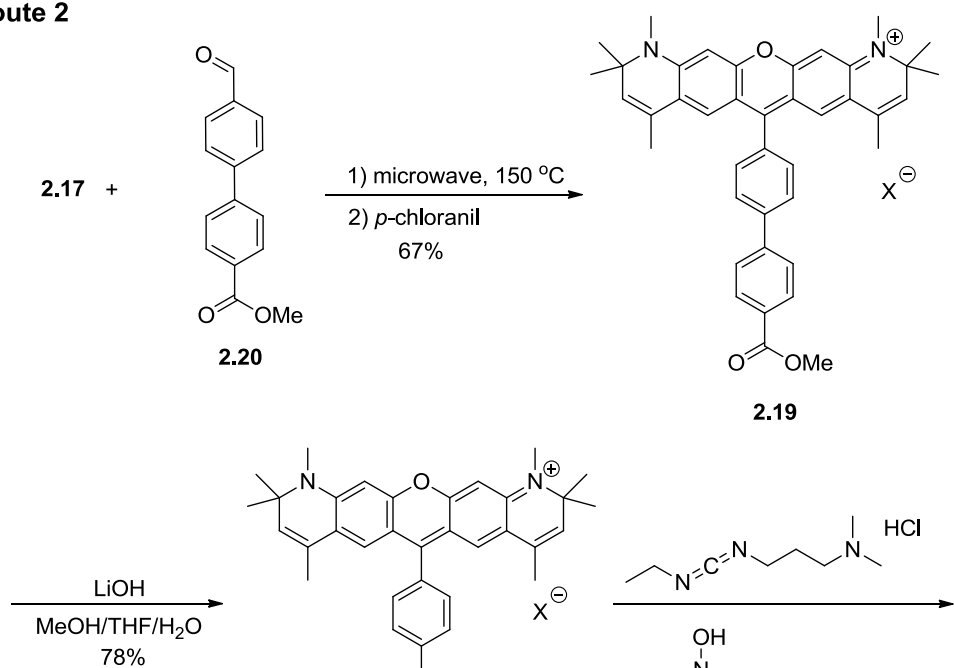

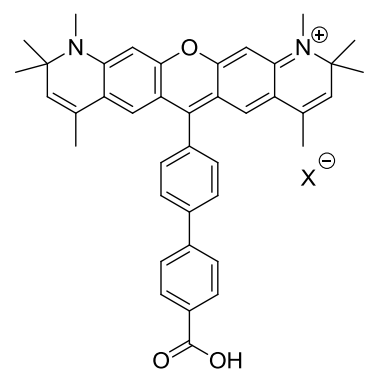

2.21

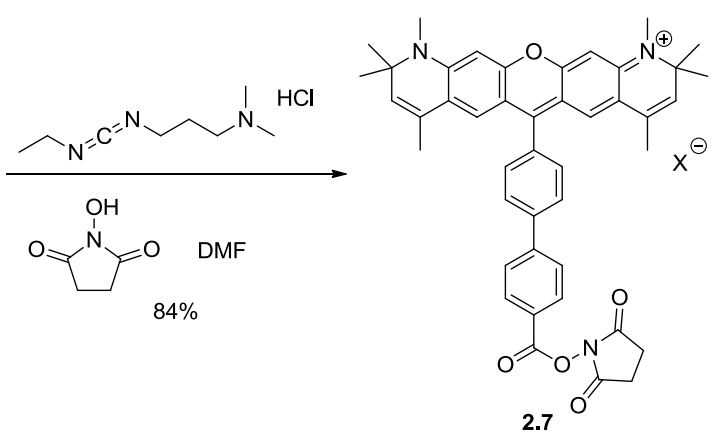

Scheme 2.3 Synthesis of compound 2.7 


\subsubsection{Synthesis of inflexible rhodamine, 2.8}
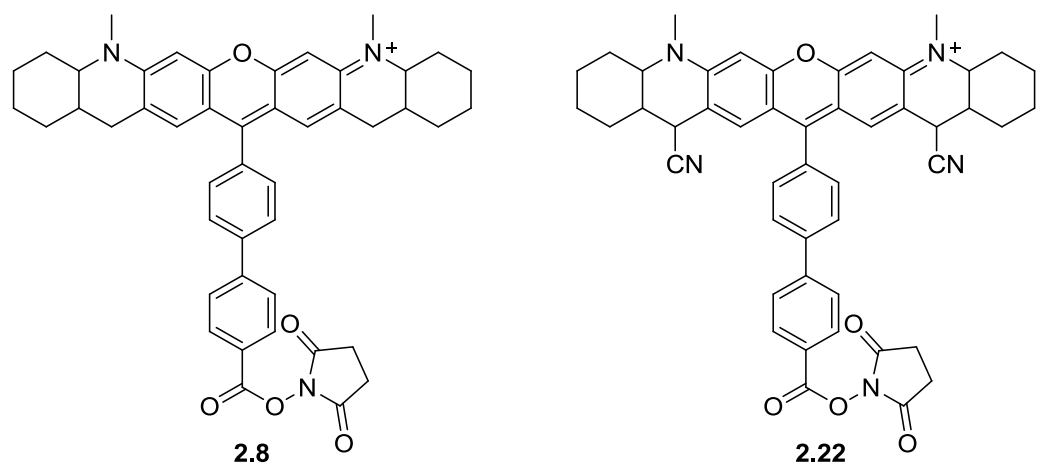

Figure 2.9 Designed extended-inflexible fluorophore with additional [1,2]-butano fused rings $\mathbf{2 . 8}$ and $\mathbf{2 . 2 2}$

Two extended inflexible Texas Red with additional [1,2]-butano fused rings on the fluorophore scaffold are shown in Figure 2.9. While compound $\mathbf{2 . 8}$ fulfills the proposed architectural goals, compound 2.22 with its additional cyano groups is also of interest. The cyano substituents may positively influence the spectra properties such as enhancing quantum yield. Retrosynthetic analysis of compound 2.22 (Figure 2.10) was envisioned as including the condensation of cyano-hydroacridinol $\mathbf{2 . 2 3}$ and commercial available methyl 4-(4-formylphenyl)benzoate 2.20, using similar reaction conditions as described above for the synthesis of compound 2.19. Therefore, in order to accomplish the goal to synthesize the cyano-hydroacridinol $\mathbf{2 . 2 3}$, a divergent route was pictured as incorporating the ring opening of aziridine $\mathbf{2 . 2 7}$ by nucleophilic substitution with bromophenyl acetonitrile $\mathbf{2 . 2 4}$ followed by Pd-catalyzed intramolecular C-N cycloaddition. ${ }^{61}$ Bromophenyl acetonitrile $\mathbf{2 . 2 4}$ can be synthesized from aldehyde $\mathbf{2 . 2 6}$ via reduction and bromination followed by substitution with cyanide. Aziridine 2.27 can 
be synthesized via a Mitsunobu reaction using ring-opened expoxide 2.28. The overall synthesis of cyano-hydroacridinol $\mathbf{2 . 2 3}$ is shown in Scheme 2.4.

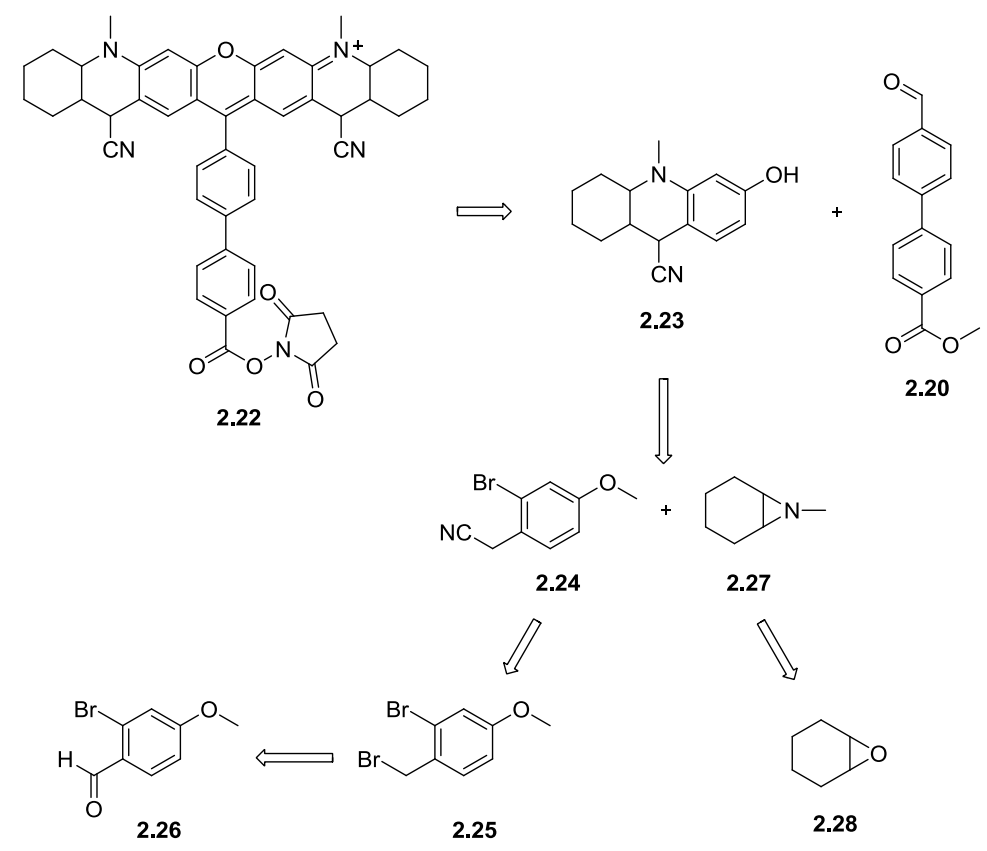

Figure 2.10 Retrosynthetic strategy for synthesis of compound $\mathbf{2 . 2 2}$

As shown in Scheme 2.4, benzyl bromide $\mathbf{2 . 2 5}$ was synthesized in two steps by using procedures as described previously by Bower $e t$ al. ${ }^{62}$ Reduction of aldehyde $\mathbf{2 . 2 6}$ afforded alcohol 2.29 in near quantitative yield with $\mathrm{NaBH}_{4}$. Alcohol 2.29 was brominated with $\mathrm{PBr}_{3}$ at $0{ }^{\circ} \mathrm{C}$ to afford benzyl bromide $\mathbf{2 . 2 5}$ in $95 \%$ yield. Cyanide $\mathbf{2 . 2 4}$ was added via an $\mathrm{S}_{\mathrm{N}} 2$ reaction in $83 \%$ yield. ${ }^{63}$ Aziridine $\mathbf{2 . 2 7}$ was prepared in two steps as described by Shen et al. ${ }^{64} \beta$-amino alcohol $\mathbf{2 . 3 0}$ was synthesized via nucleophilic addition of methyl amine to epoxide $\mathbf{2 . 2 8}$ in $\mathbf{1 0 0 \%}$ yield. However, the ring-closure of amino alcohol under Mitsunobu reaction conditions provided only a trace amount of 
aziridine 2.27. It proved hard to purify and obtain in good yield, as multiple components were observed in the crude product mixture.

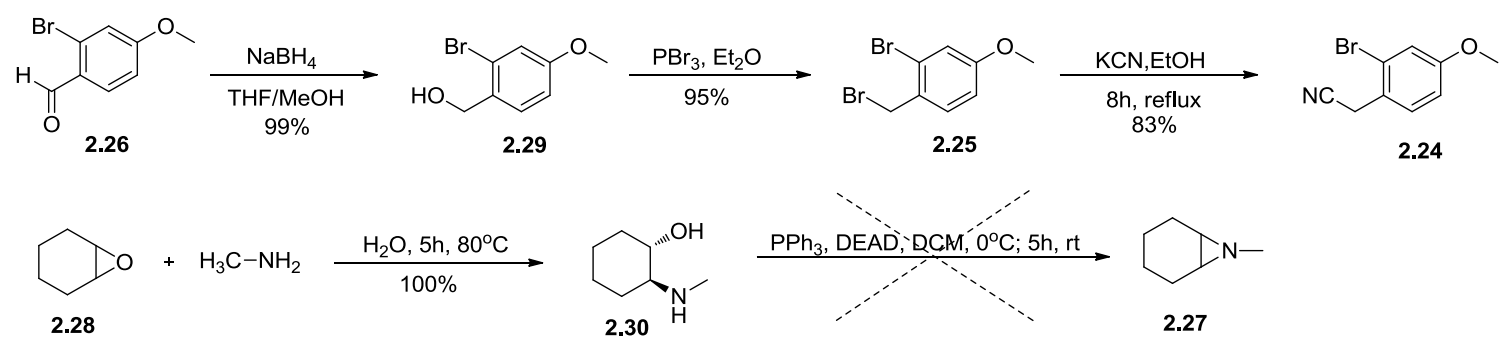

Scheme 2.4 Synthesis of precursor 2.24 and 2.27

Retrosynthetic analysis (Figure 2.11) of decahydroquinoline $\mathbf{2 . 8}$ was envisioned as occurring via the condensation of hydroacridinol $\mathbf{2 . 3 2}$ and the commercial available 2.20, using similar reaction conditions as described above for the synthesis of compound 2.19. Decarboxylative cycloaddition of isatoic anhydride 2.35 to cyclohexene 2.36 would form acridione 2.34. Reduction of the ketone and dealkylation of the methoxy group would furnish desired intermediate $\mathbf{2 . 3 2}$.

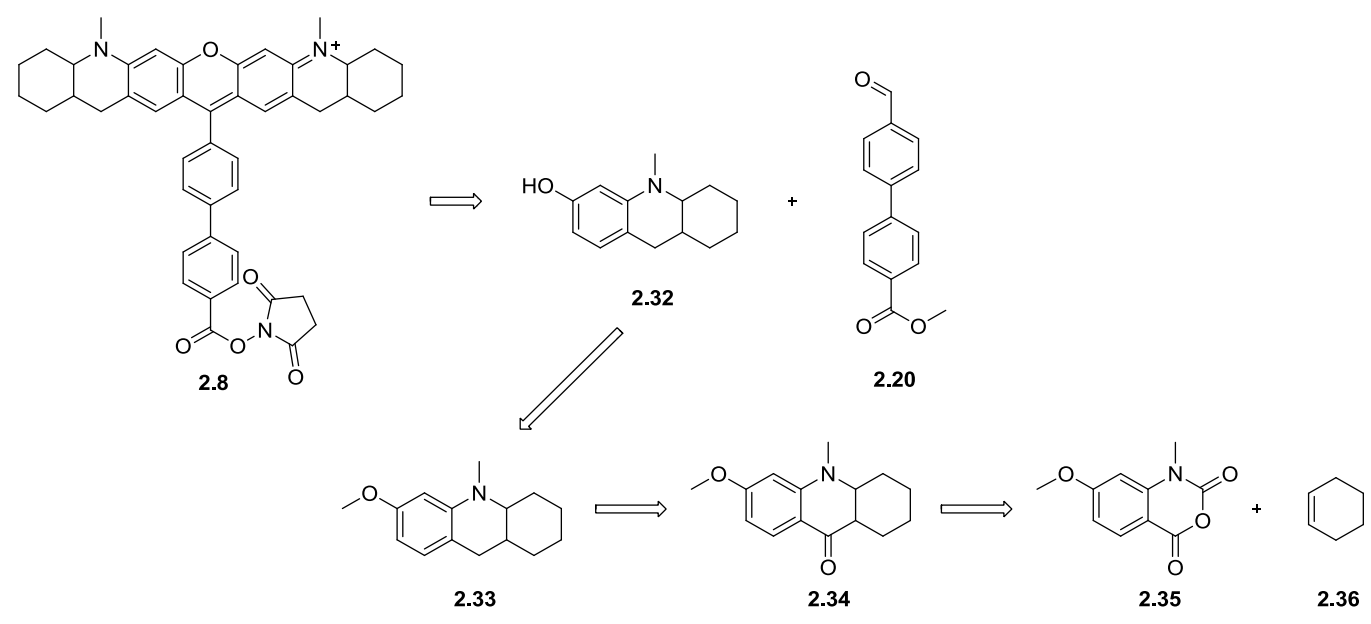

Figure 2.11 Retrosynthetic strategy for the synthesis of compound $\mathbf{2 . 8}$ 
Isatoic anhydride $\mathbf{2 . 3 9}$ was synthesized using a modified version of a procedure described by Acker et al. ${ }^{65}$ This approach involved two additional eliminations from anthranilic acid $\mathbf{2 . 3 7}$ reacting with triphosgene $\mathbf{2 . 3 8}$ under reflux condition to give isatoic anhydride $\mathbf{2 . 3 9}$ in $95 \%$ yield (Scheme 2.5). Alkylation of isatoic anhydride $\mathbf{2 . 3 9}$ with methyl iodide gave the corresponding $N$-methyl isatoic anhydride $\mathbf{2 . 3 5}$ in $93 \%$ yield. ${ }^{66}$ In order to obtain intermediate $\mathbf{2 . 3 4}$, nickel-catalyzed decarboxylative cycloaddition of isatoic anhydride 2.35 with cyclohexene 2.36 was investigated using the procedure described by Sun et al. ${ }^{67}$ Zinc was prepared and activated using a protocol described by Vogel $e t a l,{ }^{68}$ or commercially available Rieke Zinc. However, all attempts to produce the cycloaddition product $\mathbf{2 . 3 4}$ using either freshly prepared activated $\mathrm{Zn}$ or commercially available Rieke Zinc were unsuccessful. ESI MS analysis showed that a mass corresponding to an intermediate of the target compound $\mathbf{2 . 3 4}$ was present in the crude mixture. However the mass corresponding to $\mathbf{2 . 3 4}$ was not found and numerous TLC spots were observed when analyzing the product mixture.

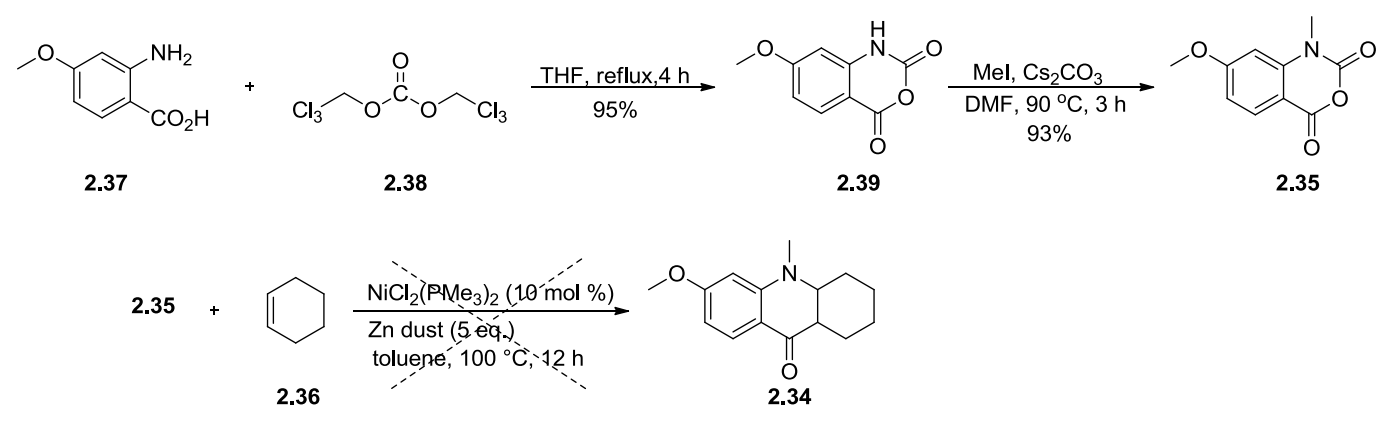

Scheme 2.5 Synthesis of intermediate $\mathbf{2 . 3 4}$ 
After several failed attempts to synthesize hydroacridinol 2.32, an alternative approach, involving no previously-reported intermediates, was designed as shown in Scheme 2.6. The retrosynthetic analysis is shown in Figure 2.12. It is envisioned a Friedel-Crafts acylation of $\mathbf{2 . 4 0}$ followed by reduction and dealkylation to afford target 2.32. Forging the C-C bond through intramolecular from $N$-phenylcarboxylic acid $\mathbf{2 . 4 0}$ to form hydroacridinone 2.34. $N$-phenylcarboxylic acid $\mathbf{2 . 4 0}$ would be derived from reductive amination via the reaction of aniline $\mathbf{2 . 4 1}$ and $\beta$-ketoester $\mathbf{2 . 4 2}$.

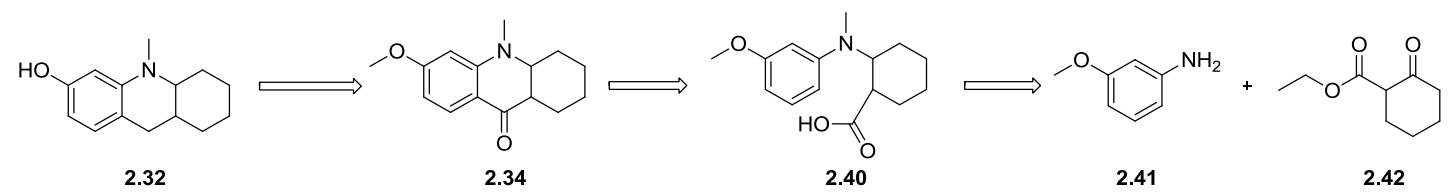

Figure 2.12 An alternative retrosynthetic strategy for attaining compound $\mathbf{2 . 3 2}$

As shown in Scheme 2.6, the reductive amination of aniline $\mathbf{2 . 4 1}$ and $\beta$-ketoester 2.42 with $\mathrm{NaBH}(\mathrm{OAc})_{3}$ affords product $\mathbf{2 . 4 3}$ in $69 \%$ yield. ${ }^{69}$ Alkylation of 2.43 with MeI gives the corresponding $N$-methylated product $\mathbf{2 . 4 4}$ in $80 \%$ yield. Compound $\mathbf{2 . 4 4}$ was hydrolyzed under basic conditions at rt to afford $\mathbf{2 . 4 0}$ in $99 \%$. After reaction optimization, the cyclization of hydroacridinone $\mathbf{2 . 4 0}$ in polyphosphoric acid (PPA) led to hydroacridinone $\mathbf{2 . 3 4}$ in a low yield of $16 \%$ via intramolecular Friedel-Crafts acylation. ${ }^{70}$ Reduction of hydroacridinone 2.34 using $\mathrm{LiAlH}_{4}$ under reflux conditions gave the corresponding acridine $\mathbf{2 . 3 3}$ in $90 \%$. $^{71}$ The target intermediate hydroacridinol 2.32 was successfully obtained in $99 \%$ yield by nucleophilic dealkylation of the methoxy ether using $48 \%$ aq. $\mathrm{HBr}$. The target compound $\mathbf{2 . 8}$ was synthesized in three steps using a similar strategy as described above for extended Texas Red 2.7, which involves the 
condensation of hydroacridinol $\mathbf{2 . 3 2}$ and methyl 4-(4-formylphenyl)benzoate $\mathbf{2 . 2 0}$ in $49 \%$ yield, and basic hydrolysis of the methyl ester $\mathbf{2 . 4 5}$ gave $\mathbf{2 . 4 6}$ in $99 \%$ yield. The activated succinimidyl ester $\mathbf{2 . 8}$ was obtained in $85 \%$ yield using EDAC as the coupling reagent.
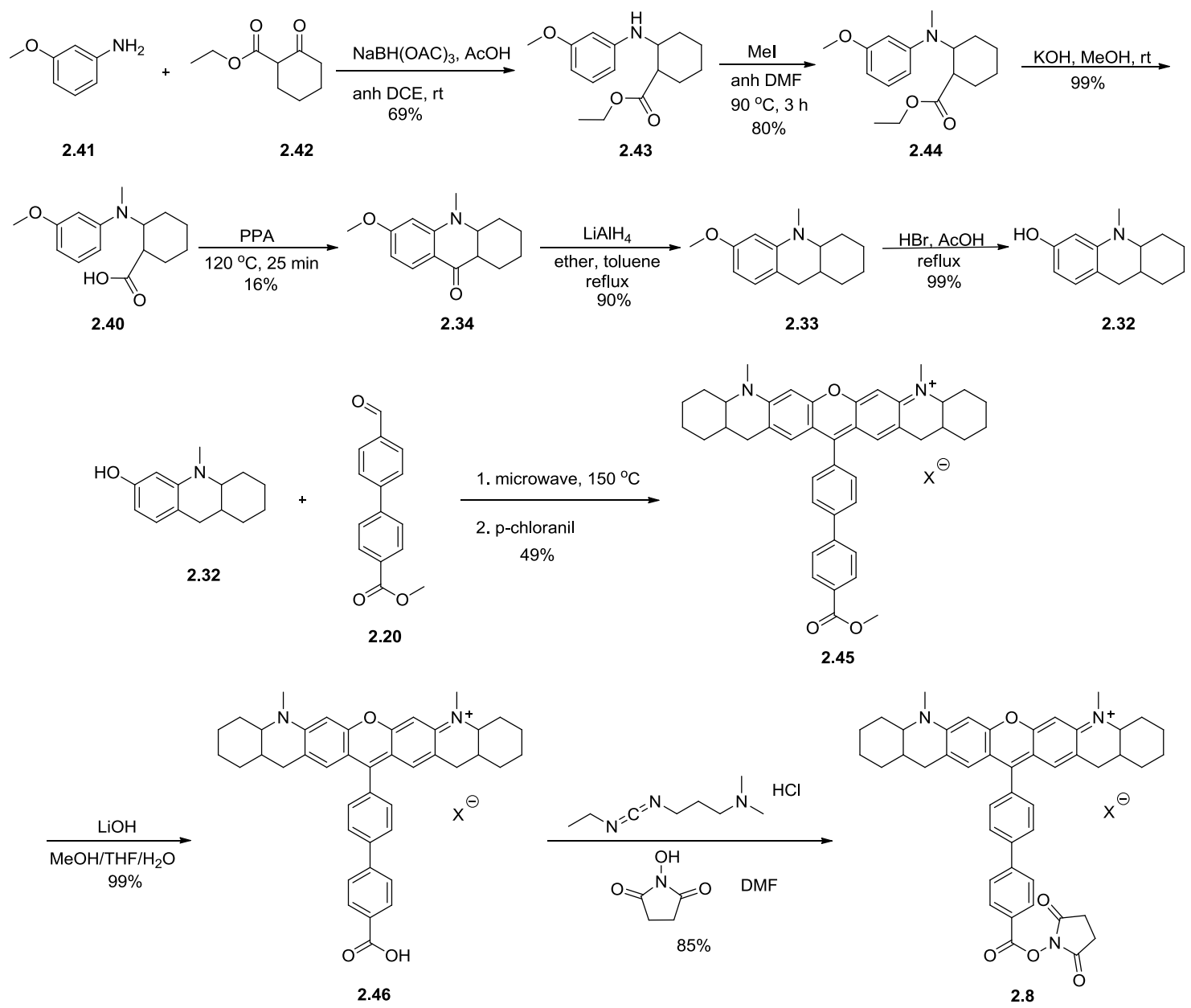

Scheme 2.6 Synthesis of compound 2.8

\subsection{Spectral properties}

In order to determine that the new fluorophores have the similar spectral properties as compared to the parent probe TR-SE (2.2), the absorbance and fluorescence 
spectra of $1.25 \mu \mathrm{M}$ solution of compound 2.2, 2.6, 2.7 and 2.8 were evaluated in organic solvent (MeOH) and buffer (PBS:DMSO 9:1).

The absorption spectrum of $\mathbf{2 . 6}$ has a similar maximum absoprtion as compared to 2.2, while compounds $\mathbf{2 . 7}$ and $\mathbf{2 . 8}$ show a $30 \%$ reduction in absorption (Figure 2.13). The fluorescence properties of 2.2, 2.6, 2.7 and 2.8 in $\mathrm{MeOH}$ and buffer are summarized in Table 2.1. As shown in Figures 2.14 and 2.15, compound $\mathbf{2 . 6}$ has only a $5 \mathrm{~nm}$ Stoke's shift change as compared to that of $\mathbf{2 . 2}$.

Compounds 2.7 and 2.8 have small wavelength shifts in their fluorescence spectra in comparison to 2.2. Compound 2.7 contains an extra double bond, which extends the conjugation leading to a slight red shift $(5 \mathrm{~nm}$ in excitation spectra and $15 \mathrm{~nm}$ in emission spectra). Compound 2.8 has somewhat less rigid aliphatic rings and shows a blue shift (25 $\mathrm{nm}$ in excitation spectra and $10 \mathrm{~nm}$ in emission spectra) compared to $\mathbf{2 . 2}$.

The relative fluorescence quantum yields $(\varphi)$ of 2.6, 2.7 and $\mathbf{2 . 8}$ were calculated by using TR-SE 2.2 as the reference standard (Table 2.1). A reduction of $30 \%$ in quantum yield is observed for compound $\mathbf{2 . 6}$ and a reduction of $17 \%$ in quantum yield is observed for the compound 2.7. However, compound $\mathbf{2 . 8}$ has $10 \%$ enhancement in quantum yield as compare to TR-SE 2.2.

TR-SE, (2.2) in both $\mathrm{MeOH}$ and $90 \%$ PBS:DMSO solvents has similar absorbance and fluorescence intensities. A higher absorbance/fluorescence intensity is observed for 2.6, 2.7 and $\mathbf{2 . 8}$ in organic solvent systems, compared to PBS/DMSO. This is attributed to the aggregation and $\pi-\pi$ stacking effects that are mitigated in $\mathbf{2 . 2}$ due to the sulfonate group. 


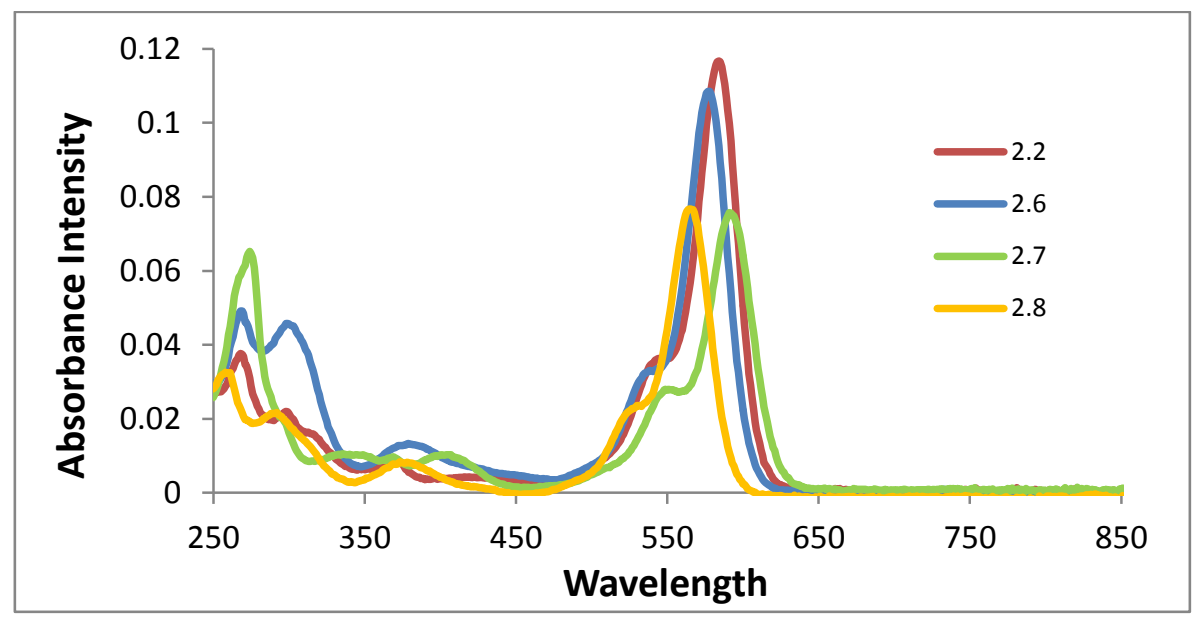

Figure 2.13 Absorption spectra of 2.2, 2.6, 2.7 and 2.8. Probe concentration: $1.25 \mu \mathrm{M}$. Solvent: $\mathrm{MeOH}$

Table 2.1 Comparison of the fluorescence properties of compounds 2.2, 2.6, 2.7 and 2.8

\begin{tabular}{|c|c|c|c|}
\hline \multirow[t]{2}{*}{ Compound } & $\mathrm{MeOH}$ & PBS:DMSO 9:1 & $\begin{array}{c}\text { Relative } \\
\text { Quantum yield }\end{array}$ \\
\hline & $\lambda \operatorname{ex} / \lambda \operatorname{em}(\mathrm{nm})$ & $\lambda \operatorname{ex} / \lambda \operatorname{em}(\mathrm{nm})$ & $(\varphi)$ \\
\hline 2.2 & $580 / 600$ & $590 / 610$ & 1 \\
\hline 2.6 & $575 / 600$ & $580 / 600$ & 0.71 \\
\hline 2.7 & $590 / 615$ & $590 / 620$ & 0.83 \\
\hline 2.8 & $560 / 590$ & $565 / 590$ & 1.1 \\
\hline
\end{tabular}




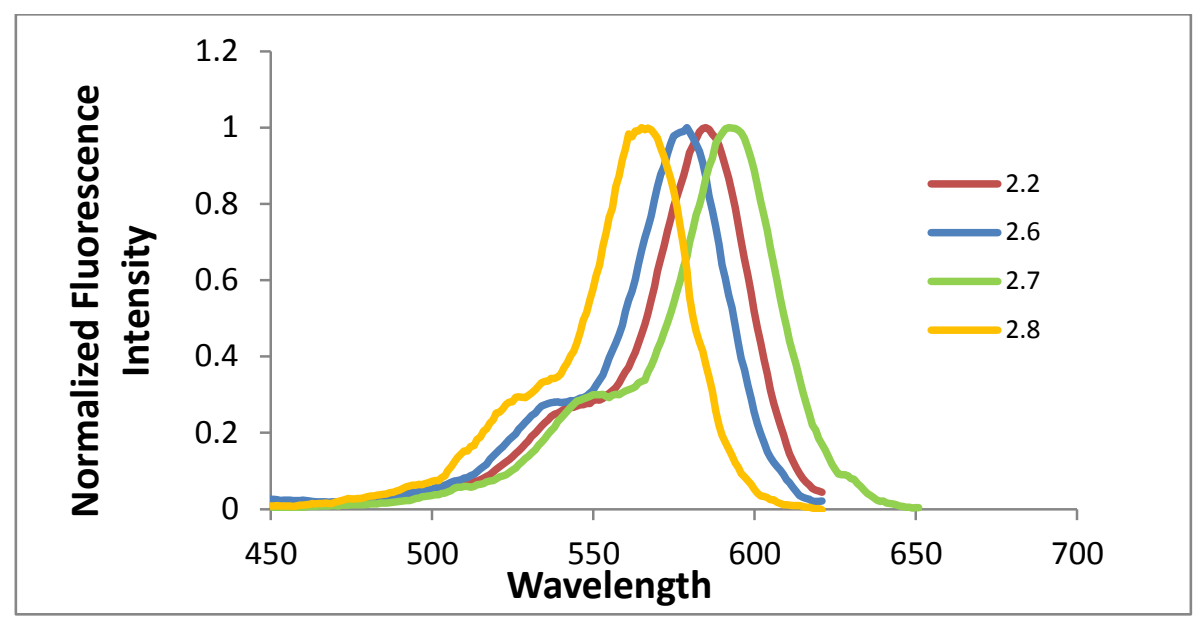

Figure 2.14 Normalized fluorescence excitation spectra of 2.2, 2.6, 2.7 and 2.8. Probe concentration: $1.25 \mu \mathrm{M}$. Solvent: $\mathrm{MeOH}$

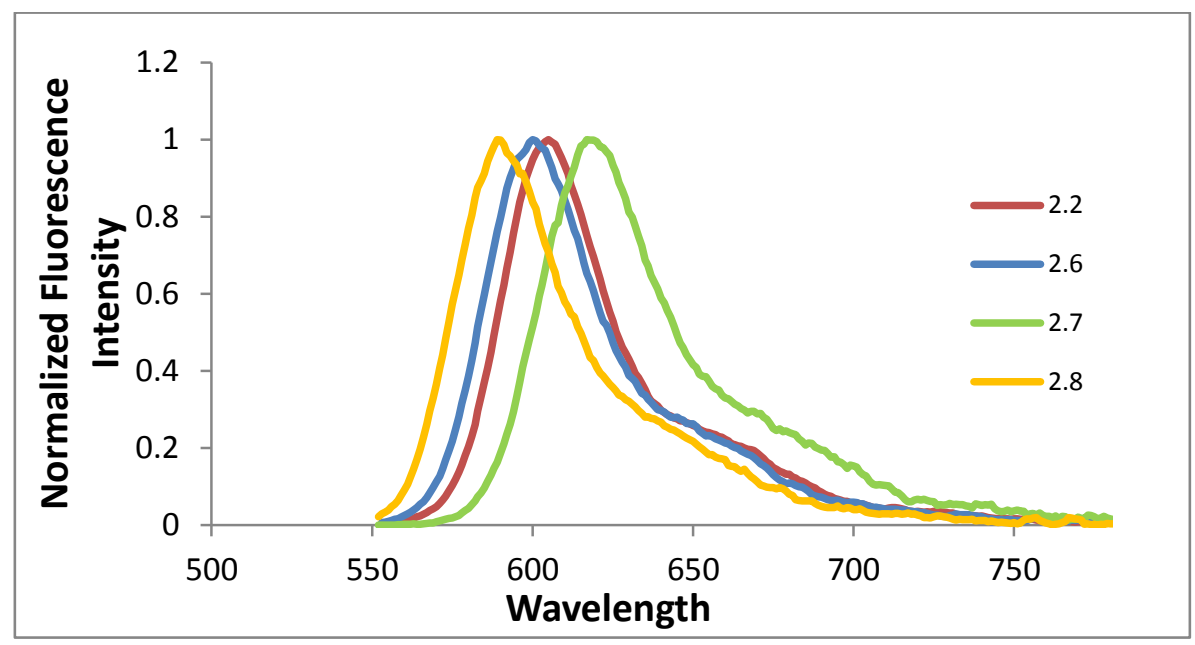

Figure 2.15 Normalized fluorescence emission spectra of 2.2, 2.6, 2.7 and 2.8. Probe concentration: $1.25 \mu \mathrm{M}$. Solvent: $\mathrm{MeOH}$ 


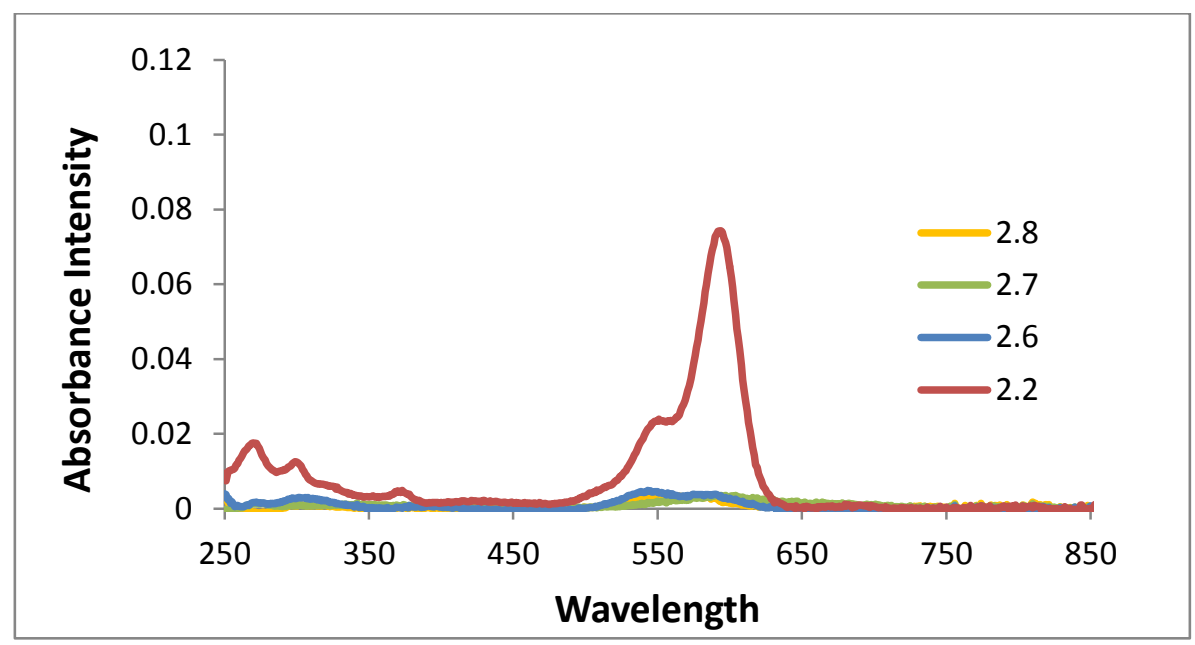

Figure 2.16 Absorption spectra of 2.2, 2.6, 2.7 and 2.8. Probe concentration: $1.25 \mu \mathrm{M}$. Solvent: PBS:DMSO 9:1

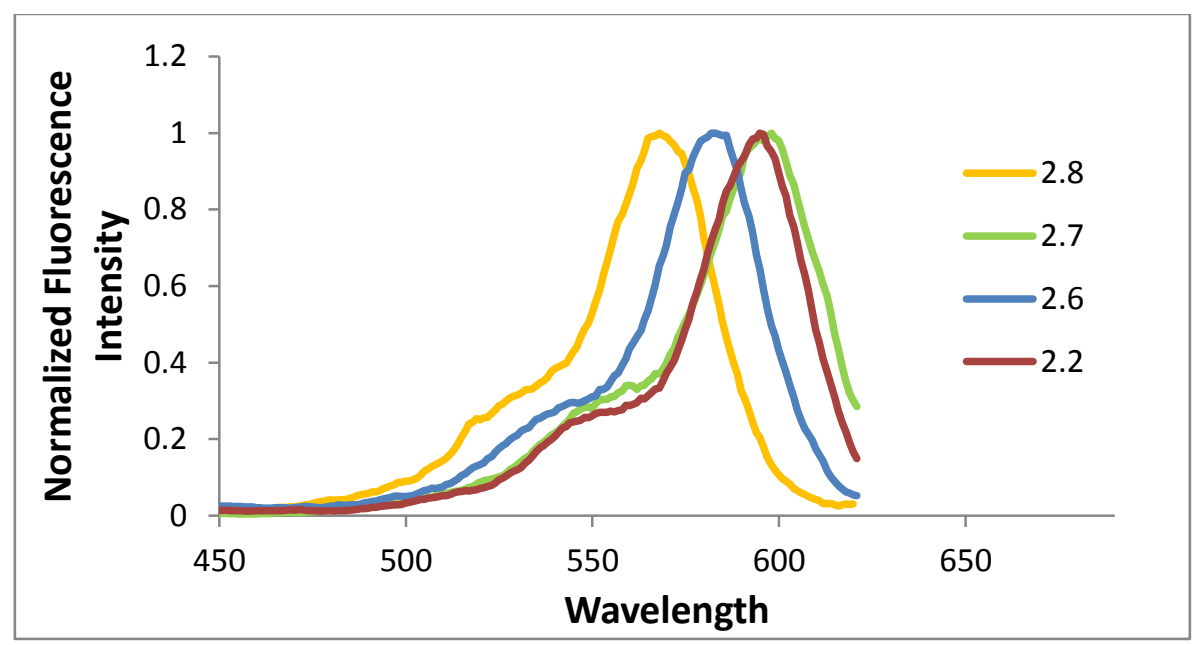

Figure 2.17 Normalized fluorescence excitation spectra of 2.2, 2.6, 2.7 and 2.8. Probe concentration: $1.25 \mu \mathrm{M}$ 


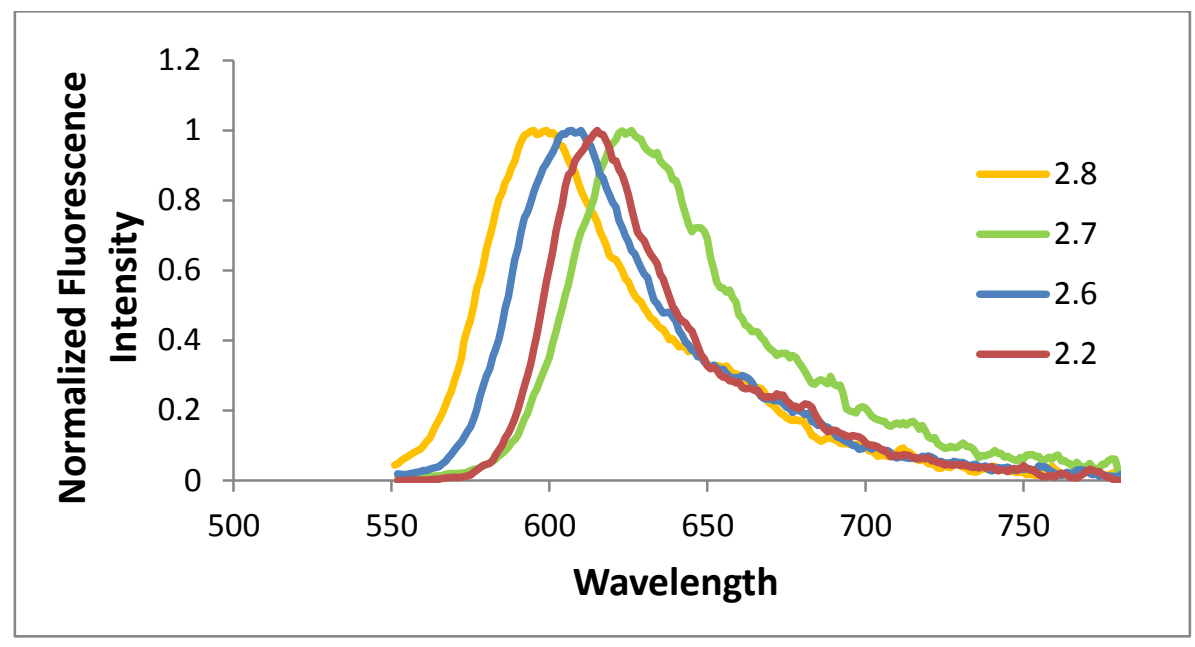

Figure 2.18 Normalized fluorescence emission spectra of 2.2, 2.6, 2.7 and 2.8. Probe concentration: $1.25 \mu \mathrm{M}$. Solvent: PBS:DMSO 9:1

\subsection{Experimental section}

\section{Material and Methods}

General. All chemicals were used as received without further purification. ${ }^{1} \mathrm{H}-$ NMR, ${ }^{13} \mathrm{C}-\mathrm{NMR}$ and were acquired on an ARX-400 Avance Bruker spectrometer. Chemical shifts $(\delta)$ are given in ppm relative to TMS. Mass spectra were obtained at the PSU Bioanalytical Mass Spectrometry Facility on a ThermoElectron LTQ-Orbitrap Discovery high resolution mass spectrometer coupled to an Accela HPLC system. Microwave synthetic procedures were performed in an Initiator ${ }^{\mathrm{TM}}$ microwave synthesizer (Biotage). Simulations were performed on a Dell precision ${ }^{\mathrm{TM}} 490$ work station loaded with CentOS 6.6 64-bit operating system using the molecular dynamics routines within the SYBYL X $\mathrm{X}^{\mathrm{TM}} 2.0$ modeling suite (Certara, L. P.). Fluorescence measurements were 
carried out on a Cary Eclipse ${ }^{\mathrm{TM}}$ fluorescence spectrophotometer (Agilent Technologies). Absorption spectra were acquired with a Cary Eclipse $^{\mathrm{TM}} 50$ Bio UV-Vis spectrophotometer.

Synthesis of compound 2.11. In a $20 \mathrm{~mL}$ microwave tube, 8-hydroxyjulolidine (380 mg, $2 \mathrm{mmol}$ ) and 4-bromobenzaldehyde (185 mg, $1 \mathrm{mmol})$ were dissolved in 7.5 $\mathrm{mL}$ of methanesulfonic acid. A magnetic stirring bar was introduced and the tube was sealed and irradiated in the microwave reactor keeping the temperature at $150{ }^{\circ} \mathrm{C}$ with stirring for $5 \mathrm{~min}$. The mixture was allowed to cool to $\mathrm{rt}$, and the tube opened. Tetrachloro-1,4-benzoquinone ( $369 \mathrm{mg}, 1.5 \mathrm{mmol}$ ) was added to the solution, and stirred for $15 \mathrm{~min}$. The dark blue mixture was neutralized to $\mathrm{pH} 7$ with $10 \mathrm{M} \mathrm{KOH}$. The solution was poured into $\mathrm{H}_{2} \mathrm{O}$ and extracted with $\mathrm{CH}_{2} \mathrm{Cl}_{2}: \mathrm{MeOH}$ 95:5 $(3 \times 100 \mathrm{~mL})$. The combined organic layers were washed with brine, dried over $\mathrm{Na}_{2} \mathrm{SO}_{4}$, and the solvent removed under vacuum. The mixture was separated to give a dark violet solid $(250 \mathrm{mg}$, 47\%). ${ }^{1} \mathrm{H}$ NMR, ${ }^{13} \mathrm{C}$ NMR and MS data are in agreement with the literature. ${ }^{56}$

Synthesis of compound 2.12. Bromorhodamine 2.11 (200 mg, $0.378 \mathrm{mmol})$ was dissolved in a solvent mixture including toluene $(2.7 \mathrm{~mL})$, aqueous $2 \mathrm{M} \mathrm{Na}_{2} \mathrm{CO}_{3}(1.2 \mathrm{~mL})$ and 4-( $N$-Boc-amino) phenylboronic acid (459 $\mathrm{mg} 1.938 \mathrm{mmol})$ in EtOH $(1.2 \mathrm{~mL})$. The mixture was deoxygenated under reduced pressure and flushed with Ar 3 times. $\mathrm{Pd}\left(\mathrm{PPh}_{3}\right)_{4}(48 \mathrm{mg}, 11 \mathrm{~mol} \%)$ was added, and the reaction mixture heated at $60^{\circ} \mathrm{C}$ overnight. The solution was poured into $\mathrm{H}_{2} \mathrm{O}$, and washed with $10 \% \mathrm{MeOH}$ in $\mathrm{CH}_{2} \mathrm{Cl}_{2}$. The organic layers were washed with brine and dried over $\mathrm{Na}_{2} \mathrm{SO}_{4}$, filtered over a short plug of celite and the solvent removed under vacuum. The mixture was separated by flash 
chromatography on $\mathrm{SiO}_{2}$ using $\mathrm{CH}_{2} \mathrm{Cl}_{2}: \mathrm{MeOH}$ 9:1 as the eluent to give a dark violet solid (109 mg, 45\%). ${ }^{1} \mathrm{H}$ NMR $\left(\mathrm{CDCl}_{3}\right): 1.48\left(9 \mathrm{H}, \mathrm{s}, \mathrm{CH}_{3}\right), 1.92\left(4 \mathrm{H}, \mathrm{m}, \mathrm{CH}_{2}\right), 2.05(4 \mathrm{H}, \mathrm{m}$, $\left.\mathrm{CH}_{2}\right), 2.65\left(4 \mathrm{H}, \mathrm{t}, J=6.0 \mathrm{~Hz}, \mathrm{CH}_{2}\right), 2.98\left(4 \mathrm{H}, \mathrm{d}, J=6.3 \mathrm{~Hz}, \mathrm{CH}_{2}\right), 3.47(4 \mathrm{H}, \mathrm{t}, J=5.7 \mathrm{~Hz}$, $\left.\mathrm{CH}_{2}\right), 3.51\left(4 \mathrm{H}, \mathrm{t}, J=5.6 \mathrm{~Hz}, \mathrm{CH}_{2}\right), 6.83(2 \mathrm{H}, \mathrm{s}, \mathrm{CH}), 6.95(1 \mathrm{H}, \mathrm{s}, \mathrm{NH}), 7.29(2 \mathrm{H}, \mathrm{s}, J=$ $8.2 \mathrm{~Hz}, \mathrm{CH}$ ), $7.50(2 \mathrm{H}, \mathrm{d}, J=8.6 \mathrm{~Hz}, \mathrm{CH}), 7.56(2 \mathrm{H}, \mathrm{d}, J=8.6 \mathrm{~Hz}, \mathrm{CH}), 7.70(2 \mathrm{H}, \mathrm{d}, J=$ $8.2 \mathrm{~Hz}, \mathrm{CH}) .{ }^{13} \mathrm{C} \mathrm{NMR}\left(\mathrm{CDCl}_{3}\right): 19.9,20.0,20.8,27.8,28.5,50.6,51.1,80.8,105.5$, $112.9,119.1,123.8,126.8,126.9,127.7,130.1,131.1,134.1,138.9,142.2,151.2,152.3$, 153.0, 154.7. HRMS (ESI): $\mathrm{m} / z\left[\mathrm{M}^{+}\right]$calculated for $\mathrm{C}_{42} \mathrm{H}_{44} \mathrm{~N}_{3} \mathrm{O}_{3}: 638.3377$; observed: 638.3378.

Synthesis of compound 2.13. To a stirred solution of compound 2.12 (97 mg, $0.151 \mathrm{mmol})$ in $\mathrm{CH}_{2} \mathrm{Cl}_{2}(3 \mathrm{~mL}) \mathrm{kept}$ at $0{ }^{\circ} \mathrm{C}$, TFA $(4.5 \mathrm{~mL})$ was added dropwise. The reaction was stirred for $2 \mathrm{~h}$ at $0{ }^{\circ} \mathrm{C}$, and neutralized with saturated aqueous $\mathrm{NaHCO}_{3}$ to $\mathrm{pH}$ 7. The organic layers were washed with $\mathrm{H}_{2} \mathrm{O}$, then brine, dried over $\mathrm{Na}_{2} \mathrm{SO}_{4}$, and the solvent removed under vacuum. The mixture was separated by flash chromatography on $\mathrm{SiO}_{2}$ using a gradient solvent $\mathrm{CH}_{2} \mathrm{Cl}_{2}: \mathrm{MeOH}$ 95:5 to $90: 10$ as the eluent to afford a dark violet solid (yield: $72.4 \mathrm{mg}, 89 \%) .{ }^{1} \mathrm{H}$ NMR $\left(\mathrm{CDCl}_{3}\right): 1.99\left(4 \mathrm{H}, \mathrm{m}, \mathrm{CH}_{2}\right), 2.12(4 \mathrm{H}, \mathrm{m}$, $\left.\mathrm{CH}_{2}\right), 2.72\left(4 \mathrm{H}, \mathrm{t}, J=6.0 \mathrm{~Hz}, \mathrm{CH}_{2}\right), 3.05\left(4 \mathrm{H}, \mathrm{d}, J=6.3 \mathrm{~Hz}, \mathrm{CH}_{2}\right), 3.53(4 \mathrm{H}, \mathrm{t}, J=5.7 \mathrm{~Hz}$, $\left.\mathrm{CH}_{2}\right), 3.57\left(4 \mathrm{H}, \mathrm{t}, J=5.7 \mathrm{~Hz}, \mathrm{CH}_{2}\right), 6.82(2 \mathrm{H}, \mathrm{d}, J=8.5 \mathrm{~Hz}, \mathrm{CH}), 6.92(2 \mathrm{H}, \mathrm{s}, \mathrm{CH}), 7.33$ $(2 \mathrm{H}, \mathrm{d}, J=8.3 \mathrm{~Hz}, \mathrm{CH}), 7.74(2 \mathrm{H}, \mathrm{d}, J=8.5 \mathrm{~Hz}, \mathrm{CH}), 7.79(2 \mathrm{H}, \mathrm{d}, J=8.3 \mathrm{~Hz}, \mathrm{CH}) .{ }^{13} \mathrm{C}$ NMR $\left(\mathrm{CDCl}_{3}\right): 19.9,20.0,20.8,27.8,50.6,51.1,105.6,113.0,115.7,123.7,126.4$, 126.9, 128.1, 129.6, 130.1, 130.3, 142.8, 147.1, 151.2, 152.4, 155.0. HRMS (ESI): $\mathrm{m} / \mathrm{z}$ $\left[\mathrm{M}^{+}\right]$calculated for $\mathrm{C}_{37} \mathrm{H}_{36} \mathrm{~N}_{3} \mathrm{O}$ : 538.2853; observed: 538.2855 . 
Synthesis of compound 2.6. To a stirred solution of compound 2.13 (18.1 mg, $0.0325 \mathrm{mmol})$ in anhydrous $\mathrm{CH}_{2} \mathrm{Cl}_{2}(8 \mathrm{~mL})$ was added $1,1^{\prime}$-thiocarbonyldi-2(1H)pyridone $(15.6 \mathrm{mg}, 0.0672 \mathrm{mmol})$. The resulting mixture was stirred at $\mathrm{rt}$ for $18 \mathrm{~h}$ under Ar. The mixture was poured into $\mathrm{CH}_{2} \mathrm{Cl}_{2}$, washed with $\mathrm{H}_{2} \mathrm{O}$, then brine, dried over $\mathrm{Na}_{2} \mathrm{SO}_{4}$, and the solvent removed under vacuum. The residue was purified by flash chromatography on $\mathrm{SiO}_{2}$ using $\mathrm{CH}_{2} \mathrm{Cl}_{2}: \mathrm{MeOH}$ 95:5 as the eluent to give a dark violet solid (13.8 mg, 71\%). ${ }^{1} \mathrm{H}$ NMR $\left(\mathrm{CDCl}_{3}\right): 1.98\left(4 \mathrm{H}, \mathrm{m}, \mathrm{CH}_{2}\right), 2.11\left(4 \mathrm{H}, \mathrm{m}, \mathrm{CH}_{2}\right), 2.72(4 \mathrm{H}$, $\left.\mathrm{t}, J=5.9 \mathrm{~Hz}, \mathrm{CH}_{2}\right), 3.04\left(1 \mathrm{H}, \mathrm{t}, J=6.3 \mathrm{~Hz}, \mathrm{CH}_{2}\right), 3.53(4 \mathrm{H}, \mathrm{dd}, J=8.3 \mathrm{~Hz}, J=6.2 \mathrm{~Hz}$, $\left.\mathrm{CH}_{2}\right), 3.56\left(4 \mathrm{H}, \mathrm{t}, J=5.6 \mathrm{~Hz}, \mathrm{CH}_{2}\right), 6.85(2 \mathrm{H}, \mathrm{s}, \mathrm{CH}), 7.35(2 \mathrm{H}, \mathrm{d}, J=8.5 \mathrm{~Hz}, \mathrm{CH}), 7.41$ $(2 \mathrm{H}, \mathrm{d}, J=8.3 \mathrm{~Hz}, \mathrm{CH}), 7.70(2 \mathrm{H}, \mathrm{d}, J=8.5 \mathrm{~Hz}, \mathrm{CH}), 7.79(2 \mathrm{H}, \mathrm{d}, J=8.3 \mathrm{~Hz}, \mathrm{CH}) .{ }^{13} \mathrm{C}$ NMR $\left(\mathrm{CDCl}_{3}\right): 19.8,20.0,20.8,27.8,50.6,51.1,105.6,112.8,123.9,126.5,126.6$, $127.4,128.4,130.3,131.2,132.2,134.9,138.9,141.1,151.3,152.3,154.1$. HRMS (ESI): $m / z\left[\mathrm{M}^{+}\right]$calculated for $\mathrm{C}_{38} \mathrm{H}_{34} \mathrm{~N}_{3} \mathrm{OS}: 580.2417$; observed: 580.2419 .

Synthesis of compound 2.15. Compound 2.15 was synthesized using a modified procedure reported previously. ${ }^{59}$ Under Ar, ytterbium(III) triflate $(353 \mathrm{mg}, 0.568 \mathrm{mmol})$ was added to solution of $m$-anisidine $(1 \mathrm{~g}, 8.12 \mathrm{mmol})$ in HPLC grade acetone $(40 \mathrm{~mL})$. The reaction mixture was stirred at $\mathrm{rt}$ for $24 \mathrm{~h}$. Acetone was removed in vacuo and the residue was dissolved in EtOAc, washed with $\mathrm{H}_{2} \mathrm{O}$, brine and dried over $\mathrm{Na}_{2} \mathrm{SO}_{4}$ filtered and the solvent evaporated under vacuum. The mixture was then separated by flash column chromatography on $\mathrm{SiO}_{2}$ using Hexane:EtOAc 8:1 as the eluent to afford a pale yellow oily product $(1.32 \mathrm{~g}, 80 \%) .{ }^{1} \mathrm{H}$ NMR, ${ }^{13} \mathrm{C}$ NMR and MS data are in agreement with the literature. ${ }^{59}$ 
Synthesis of compound 2.16. Compound 2.16 was synthesized using a modified procedure reported previously. ${ }^{59}$ Under Ar, compound 2.15 (5.55 g, $\left.27.3 \mathrm{mmol}\right), \mathrm{Cs}_{2} \mathrm{CO}_{3}$ (4.98 g, $15.29 \mathrm{mmol})$, and MeI $(6.46 \mathrm{~mL}, 103.75 \mathrm{mmol})$ were added to anhydrous DMF $(15 \mathrm{~mL})$ and stirred at $90{ }^{\circ} \mathrm{C}$ for $3 \mathrm{~h}$. DMF was removed in vacuo and the residue poured into $\mathrm{H}_{2} \mathrm{O}$ and washed with EtOAc $(3 \times 200 \mathrm{~mL})$. The combined organic layers were washed with brine and dried over $\mathrm{Na}_{2} \mathrm{SO}_{4}$. The solvent was removed under reduced pressure and a colorless oily product $(5.28 \mathrm{~g}, 89 \%)$ was obtained. ${ }^{1} \mathrm{H}$ NMR, ${ }^{13} \mathrm{C}$ NMR and MS data are in agreement with the literature. ${ }^{59}$

Synthesis of compound 2.17. Compound 2.17 was synthesized using a modified procedure reported previously. ${ }^{59}$ Under Ar, compound 2.16 (3.05 g, 14.04 mmol) was dissolved in glacial $\mathrm{AcOH}(8.19 \mathrm{~mL}) .48 \%$ aqueous $\mathrm{HBr}(10.05 \mathrm{~mL}, 88.84 \mathrm{mmol})$ was added and the mixture heated at reflux $\left(118^{\circ} \mathrm{C}\right)$ for $8 \mathrm{~h}$. After cooling, the solution was neutralized to about $\mathrm{pH} 5-6$ with $30 \%$ aq. $\mathrm{NaOH}$. The aqueous phase was extracted with $\mathrm{CH}_{2} \mathrm{Cl}_{2}(3 \times 150 \mathrm{~mL})$ and the combined organic layers were washed with brine and dried over $\mathrm{Na}_{2} \mathrm{SO}_{4}$. The solvent was evaporated under reduced pressure. The mixture was then separated by flash column chromatography on $\mathrm{SiO}_{2}$ using Hexane:EtOAc 5:1 as the eluent to yield dark red oily product $(1.54 \mathrm{~g}, 54 \%) .{ }^{1} \mathrm{H}$ NMR, ${ }^{13} \mathrm{C}$ NMR and MS data are in agreement with the literature. ${ }^{59}$

Synthesis of compound 2.19. In a $5 \mathrm{~mL}$ microwave tube, compound 2.17 (85 mg, $0.737 \mathrm{mmol})$ and methyl 4-(4-formylphenyl)benzoate $(50 \mathrm{mg}, 0.208 \mathrm{mmol})$ were dissolved in $1 \mathrm{~mL} \mathrm{CH}_{2} \mathrm{Cl}_{2}$. The solvent was purged using an $\mathrm{N}_{2}$ stream. The mixture was heated in a microwave reactor at $150{ }^{\circ} \mathrm{C}$ for $10 \mathrm{~min}$. The mixture was dissolved in 
$\mathrm{CH}_{2} \mathrm{Cl}_{2}: \mathrm{MeOH}(95: 5,1 \mathrm{~mL})$ and tetrachloro-1,4-benzoquinone (76.75 mg, $0.312 \mathrm{mmol}$ ) was added to the solution, and vortexed at $1000 \mathrm{rpm}$ for $15 \mathrm{~min}$. The solvent was purged using an $\mathrm{N}_{2}$ stream. The mixture was separated via a short $\mathrm{SiO}_{2}$ plug using DCM:MeOH 97:3 as the eluent to afford compound $\mathbf{2 . 1 9}$ as a purple solid $(85.15 \mathrm{mg}, 67 \%) .{ }^{1} \mathrm{H}$ $\operatorname{NMR}\left(\mathrm{CDCl}_{3}\right): 1.49(12 \mathrm{H}, \mathrm{s}), 1.80(6 \mathrm{H}, \mathrm{s}) 3.21(6 \mathrm{H}, \mathrm{s}), 3.97(3 \mathrm{H}, \mathrm{s}), 5.51(2 \mathrm{H}, \mathrm{s}), 6.85$ $(2 \mathrm{H}, \mathrm{s}), 6.96(2 \mathrm{H}, \mathrm{s}), 7.52(2 \mathrm{H}, \mathrm{d}, J=8.4 \mathrm{~Hz}), 7.81(2 \mathrm{H}, \mathrm{d}, J=8.6 \mathrm{~Hz}), 7.91(2 \mathrm{H}, \mathrm{d}, J=$ $8.4 \mathrm{~Hz}), 8.18(2 \mathrm{H}, \mathrm{d}, J=8.6 \mathrm{~Hz}) .{ }^{13} \mathrm{C} \mathrm{NMR}\left(\mathrm{CDCl}_{3}\right): 18.5,29.44,29.82,33.51,52.43$, $59.96,96.20,113.79,122.00,123.64,125.59,127.28,127.76,129.97,130.23,130.51$, 132.08, 132.75, 141.88, 143.95, 153.46, 154.12, 158.45, 166.91. HRMS (ESI): m/z [M $\left.{ }^{+}\right]$ calculated for $\mathrm{C}_{41} \mathrm{H}_{41} \mathrm{~N}_{2} \mathrm{O}_{3}{ }^{+}$: 609.3112; observed 609.3125.

Synthesis of compound 2.21. Compound 2.19 (36 $\mathrm{mg}, 0.059 \mathrm{mmol}$ ) was dissolved in MeOH:THF: $\mathrm{H}_{2} \mathrm{O}$ (5:3:1, $\left.0.9 \mathrm{~mL}\right)$ and $\mathrm{LiOH}(7.07 \mathrm{mg}, 0.295 \mathrm{mmol})$ was added. The reaction was stirred at rt overnight. After the reaction was complete (TLC), the residue was dissolved in $\mathrm{CH}_{2} \mathrm{Cl}_{2}: \mathrm{H}_{2} \mathrm{O}(1: 1,2 \mathrm{~mL}) .1 \mathrm{~N} \mathrm{HCl}$ was slowly added until the mixture was at $\mathrm{pH}$ 5. The aqueous layer was extracted with $\mathrm{CH}_{2} \mathrm{Cl}_{2}(3 \times 5 \mathrm{~mL})$, and the combined organic layers were washed with brine and dried over $\mathrm{Na}_{2} \mathrm{SO}_{4}$. The solvent was evaporated under reduced pressure to afford compound $\mathbf{2 . 2 1}$ as a purple solid (27.43 $\mathrm{mg}, 78 \%) .{ }^{1} \mathrm{H} \mathrm{NMR}\left(\mathrm{CD}_{3} \mathrm{OD}\right): 1.52(12 \mathrm{H}, \mathrm{s}), 1.83(6 \mathrm{H}, \mathrm{s}) 3.21(6 \mathrm{H}, \mathrm{s}), 5.69(2 \mathrm{H}, \mathrm{s}), 6.86$ $(2 \mathrm{H}, \mathrm{s}), 7.09(2 \mathrm{H}, \mathrm{s}), 7.65(2 \mathrm{H}, \mathrm{d}, J=8.3 \mathrm{~Hz}), 7.91(2 \mathrm{H}, \mathrm{d}, J=8.3 \mathrm{~Hz}), 8.05(2 \mathrm{H}, \mathrm{d}, J=$ $8.3 \mathrm{~Hz}), 8.16(2 \mathrm{H}, \mathrm{d}, J=8.3 \mathrm{~Hz}) .{ }^{13} \mathrm{C} \mathrm{NMR}\left(\mathrm{CD}_{3} \mathrm{OD}\right): 18.26,29.16,33.44,61.26,96.49$, $114.89,123.14,124.77,126.63,128.17,128.75,131.61,133.38,134.13,143.18,145.14$, 
154.82, 156.00, 159.86. HRMS (ESI): $\mathrm{m} / \mathrm{z}\left[\mathrm{M}^{+}\right]$calculated for $\mathrm{C}_{40} \mathrm{H}_{39} \mathrm{~N}_{2} \mathrm{O}_{3}{ }^{+}: 595.2955$; observed 595.2962.

Synthesis of compound 2.7. Compound 2.21 (20 mg, $0.033 \mathrm{mmol}$ ) was dissolved in $0.2 \mathrm{~mL}$ of anhydrous THF. EDAC $(7.72 \mathrm{mg}, 0.04 \mathrm{mmol})$ was added in one portion followed by $N$-Hydroxy succinimide (NHS) $(4.64 \mathrm{mg}, 0.04 \mathrm{mmol})$. The reaction was stirred at $\mathrm{rt}$ for $24 \mathrm{~h}$. Another 10 equiv of EDAC (64.32 mg, $0.336 \mathrm{mmol})$ were added and the reaction stirred at $\mathrm{rt}$ overnight. The reaction mixture was poured into $10 \mathrm{~mL}$ of 50 $\mathrm{mM}$ pH 6 phosphate buffer and extracted with $\mathrm{CH}_{2} \mathrm{Cl}_{2}(3 \times 15 \mathrm{~mL})$. The combined organic layers were washed with brine and dried over $\mathrm{Na}_{2} \mathrm{SO}_{4}$, and the solvent evaporated under reduced pressure. The mixture was separated via a short $\mathrm{SiO}_{2}$ plug using $\mathrm{CH}_{2} \mathrm{Cl}_{2}: \mathrm{MeCN}$ 1:1, followed by gradient elution with $\mathrm{CH}_{2} \mathrm{Cl}_{2}: \mathrm{MeOH} 98: 2$ to $95: 5$ to afford the target compound 2.7 as a purple solid $(19.55 \mathrm{mg}, 84 \%) .{ }^{1} \mathrm{H} \mathrm{NMR}\left(\mathrm{CDCl}_{3}\right)$ : $1.50(12 \mathrm{H}, \mathrm{s}), 1.81(6 \mathrm{H}, \mathrm{s}), 1.95(4 \mathrm{H}, \mathrm{s}), 3.23(6 \mathrm{H}, \mathrm{s}), 5.52(2 \mathrm{H}, \mathrm{s}), 6.86(2 \mathrm{H}, \mathrm{s}), 6.95(2 \mathrm{H}$, s), $8.28(2 \mathrm{H}, \mathrm{d}, J=8.4 \mathrm{~Hz}), 7.93(2 \mathrm{H}, \mathrm{d}, J=8.2 \mathrm{~Hz}), 7.94(2 \mathrm{H}, \mathrm{d}, J=8.6 \mathrm{~Hz}), 8.27(2 \mathrm{H}$, $\mathrm{d}, J=8.3 \mathrm{~Hz}), 8.29(2 \mathrm{H}, \mathrm{d}, J=8.6 \mathrm{~Hz}) .{ }^{13} \mathrm{C} \mathrm{NMR}\left(\mathrm{CDCl}_{3}\right): 18.54,25.87,29.46,33.62$, $60.00,96.25,113.79,121.92,123.70,124.86,125.57,127.71,127.90,130.34,131.50$, $132.80,141.28,145.95,153.48,158.45,161.72,169.39 . \operatorname{HRMS}(\mathrm{ESI}): \mathrm{m} / \mathrm{z}\left[\mathrm{M}^{+}\right]$ calculated for $\mathrm{C}_{44} \mathrm{H}_{42} \mathrm{~N}_{3} \mathrm{O}_{5}{ }^{+}$: 692.3119; observed 692.3129.

Synthesis of compound 2.29. Under Ar, 2-bromo-4-methoxybenzaldehyde (1g, $4.65 \mathrm{mmol})$ was added to a solution of anhydrous THF (2 mL) and $\mathrm{MeOH}(2 \mathrm{~mL})$ at $\mathrm{rt}$. $\mathrm{NaBH}_{4}(88 \mathrm{mg}, 2.33 \mathrm{mmol})$ was added in portions over $5 \mathrm{~min}$. The reaction mixture was stirred at $\mathrm{rt}$ for $1.5 \mathrm{~h}$ and the solvent removed in vacuo. The residue was dissolved in 
$\mathrm{Et}_{2} \mathrm{O}$ and partitioned using $\mathrm{Et}_{2} \mathrm{O}(10 \mathrm{~mL}), \mathrm{H}_{2} \mathrm{O}(10 \mathrm{~mL})$ and $2 \mathrm{M} \mathrm{HCl}(1 \mathrm{~mL})$. The organic layer was washed with water twice, dried over $\mathrm{Na}_{2} \mathrm{SO}_{4}$ and concentrated in vacuo to afford 2.29 as a colorless oil $(1 \mathrm{~g}, 100 \%) .{ }^{1} \mathrm{H}$ NMR, ${ }^{13} \mathrm{C}$ NMR and MS data are in agreement with the literature. ${ }^{62}$

Synthesis of compound 2.25. Under Ar, compound 2.29 (900 mg, $4.15 \mathrm{mmol}$ ) was dissolved in anhydrous $\mathrm{Et}_{2} \mathrm{O}(13.5 \mathrm{~mL})$. The solution was cooled using an ice bath and $\mathrm{PBr}_{3}(780 \mathrm{mmL}, 8.29 \mathrm{mmol})$ was added. The reaction was allowed to warm to $\mathrm{rt}$ and stirred overnight. The resulting orange solution was very carefully poured into vigorously stirred ice $\mathrm{H}_{2} \mathrm{O}$ (20 mL) (CAUTION: HIGHLY EXOTHERMIC). Phases were separated, the combined organic layers were washed with saturated $\mathrm{NaHCO}_{3}(10 \mathrm{~mL})$ and dried over $\mathrm{Na}_{2} \mathrm{SO}_{4}$. The solvent was removed in vacuo to afford compound 2.25 as a white solid (1.1 g, 95\%). ${ }^{1} \mathrm{H}$ NMR, ${ }^{13} \mathrm{C}$ NMR and MS data are in agreement with the literature. $^{62}$

Synthesis of compound 2.24. Compound 2.25 (1.04 g, $3.71 \mathrm{mmol})$ was added to a solution of $\mathrm{KCN}(483 \mathrm{mg}, 7.42 \mathrm{mmol})$ in $20 \mathrm{~mL}$ EtOH. The reaction mixture was heated at reflux for $8 \mathrm{~h}$. The solvent was removed in vacuo and the residue poured into 20 $\mathrm{mL}_{2} \mathrm{O}$ and extracted with EtOAc $(3 \times 30 \mathrm{~mL})$. The organic layers were combined, washed with brine $(20 \mathrm{~mL})$, dried over $\mathrm{Na}_{2} \mathrm{SO}_{4}$ and concentrated in vacuo to afford compound 2.24 as a white solid (696 mg, 83\%). ${ }^{1} \mathrm{H}$ NMR, ${ }^{13} \mathrm{C}$ NMR and MS data are in agreement with the literature. ${ }^{63}$

Synthesis of compound 2.30. 40 wt. \% methyl amine solution $(6.61 \mathrm{~mL}, 76.42$ mmol) was added to cyclohexene oxide $(5.15 \mathrm{~mL}, 50.95 \mathrm{mmol})$ dropwise at $0{ }^{\circ} \mathrm{C}$ over $1 \mathrm{~h}$. 
The solution was allowed to warm to rt, stirred overnight and refluxed at $100{ }^{\circ} \mathrm{C}$ for $3 \mathrm{~h}$. After reaction completion (TLC) the solution was cooled to $0{ }^{\circ} \mathrm{C}$ and $30 \%$ aq. $\mathrm{NaOH}$ was added to attain a $\mathrm{pH}>12$. The reaction mixture was extracted with $\mathrm{Et}_{2} \mathrm{O}(3 \times 200 \mathrm{~mL})$ and dried over $\mathrm{Na}_{2} \mathrm{SO}_{4}$ and concentrated in vacuo to afford compound $\mathbf{2 . 2 6}$ as a colorless oil (6.58 g, 100\%). ${ }^{1} \mathrm{H} \mathrm{NMR},{ }^{13} \mathrm{C} \mathrm{NMR}$ and $\mathrm{MS}$ data are in agreement with the literature. $^{64}$

Synthesis of compound 2.39. Compound 2.39 was synthesized using a modified procedure described previously by Acker et al. ${ }^{65}$ Under Ar, 2-amino-4-methoxybenzoic acid (3 g, $17.95 \mathrm{mmol})$ was dissolved in $18 \mathrm{~mL}$ of anhydrous THF. Triphosgene $(2.05 \mathrm{~g}$, $6.82 \mathrm{mmol}$ ) was weighed in a glove box and dissolved in $6 \mathrm{~mL}$ anhydrous THF. The triphosgene solution was withdrawn by syringe and added dropwise to the benzoic acid solution over $1 \mathrm{~h}$. The reaction mixture was heated at reflux $\left(76{ }^{\circ} \mathrm{C}\right)$ for $2 \mathrm{~h}$. The solvent was removed under reduced pressure, and the residue poured into $30 \mathrm{~mL}$ of cold $\mathrm{H}_{2} \mathrm{O}$. A white precipitate obtained was obtained by vacuum filtration, washed first with cold $\mathrm{H}_{2} \mathrm{O}$ then with chilled $\mathrm{CH}_{2} \mathrm{Cl}_{2}(12.8 \mathrm{~g}, 95 \%) .{ }^{1} \mathrm{H} \mathrm{NMR},{ }^{13} \mathrm{C} \mathrm{NMR}$ and $\mathrm{MS}$ data are in agreement with the literature. ${ }^{66}$

Synthesis of compound 2.35. Under Ar, isatoic anhydride (3 g, $15.53 \mathrm{mmol})$, $\mathrm{Cs}_{2} \mathrm{CO}_{3}(2.83 \mathrm{~g}, 8.7 \mathrm{mmol})$ and $\mathrm{MeI}(3.67 \mathrm{~mL}, 59.02 \mathrm{mmol})$ were added to anhydrous DMF (11 mL) and stirred at $90{ }^{\circ} \mathrm{C}$ for $3 \mathrm{~h}$. DMF was removed in vacuo, and the residue poured into $30 \mathrm{~mL}$ of cold $\mathrm{H}_{2} \mathrm{O}$. The white precipitate formed was collected by vacuum filtration and washed with cold $\mathrm{H}_{2} \mathrm{O}(2.98 \mathrm{~g}, 93 \%) .{ }^{1} \mathrm{H} \mathrm{NMR},{ }^{13} \mathrm{C}$ NMR and MS data are in agreement with the literature. ${ }^{66}$ 
Synthesis of compound 2.43. $m$-anisidine (6g, $48.72 \mathrm{mmol}$ ) was dissolved in 180 $\mathrm{mL}$ anhydrous $\mathrm{C}_{2} \mathrm{H}_{2} \mathrm{Cl}_{2}$ (DCE) followed by consecutive addition of ethyl 2cyclohexanonecarboxylate $(9.35 \mathrm{~mL}, 58.46 \mathrm{mmol}), \mathrm{NaBH}(\mathrm{OAc})_{3}(15.49 \mathrm{~g}, 73.08 \mathrm{mmol})$ and $\mathrm{AcOH}(2.79 \mathrm{~mL}, 48.72 \mathrm{mmol})$. The reaction was stirred at $\mathrm{rt}$ overnight and monitored by TLC. After the reaction was complete, $180 \mathrm{~mL}$ of saturated $\mathrm{NaHCO}_{3}$ was poured into the mixture followed by stirring for $30 \mathrm{~min}$. The reaction mixture was extracted with $\mathrm{CH}_{2} \mathrm{Cl}_{2}(3 \times 150 \mathrm{~mL})$ and the combined organic layers were dried over $\mathrm{Na}_{2} \mathrm{SO}_{4}$. The solvent was removed under reduced pressure and the residue was purified by flash column chromatography on $\mathrm{SiO}_{2}$ using Hexane:EtOAc 15:1 as the eluent to afford compound $\mathbf{2 . 4 3}$ as a colorless oil $(9.3 \mathrm{~g}, 69 \%) .{ }^{1} \mathrm{H} \mathrm{NMR}\left(\mathrm{CDCl}_{3}\right): 1.23(3 \mathrm{H}, \mathrm{t}, J=$ $7.1 \mathrm{~Hz}), 1.42-1.57(3 \mathrm{H}, \mathrm{m}) 1.64-1.75(3 \mathrm{H}, \mathrm{m}), 1.88-1.95(1 \mathrm{H}, \mathrm{m}), 1.97-2.07(1 \mathrm{H}, \mathrm{m})$, 2.84-2.88 (1H, m), 3.75-3.77 (1H, m), $3.79(3 \mathrm{H}, \mathrm{s}), 4.07-4.17(2 \mathrm{H}, \mathrm{m}), 4.4(1 \mathrm{H}, \mathrm{s}), 6.20$ $(1 \mathrm{H}, \mathrm{t}), 6.24-6.28(2 \mathrm{H}, \mathrm{m}), 7.08(1 \mathrm{H}, \mathrm{t}, J=8.1 \mathrm{~Hz}) .{ }^{13} \mathrm{C} \mathrm{NMR}\left(\mathrm{CDCl}_{3}\right): 14.30,23.03$, $23.34,26.08,29.08,44.79,51.62,55.20,60.43,99.67,102.52,106.85,130.09,148.59$, 160.97, 174.09. HRMS (ESI): $\mathrm{m} / \mathrm{z}\left[\mathrm{M}+\mathrm{H}^{+}\right]$calculated for $\mathrm{C}_{16} \mathrm{H}_{24} \mathrm{NO}_{3}: 278.1751$; observed 278.1743.

Synthesis of compound 2.44. Under Ar, compound 2.43 (6 g, $21.63 \mathrm{mmol})$ was dissolved in $16 \mathrm{~mL}$ of anhydrous DMF followed by addition of $\mathrm{Cs}_{2} \mathrm{CO}_{3}(3.95 \mathrm{~g}, 12.11$ mmol) and MeI $(5.12 \mathrm{~mL}, 82.2 \mathrm{mmol})$. The reaction mixture was heated at $90{ }^{\circ} \mathrm{C}$ and vigorously stirred for $3 \mathrm{~h}$. After the reaction was complete, DMF was removed in vacuo and the residue poured into $\mathrm{H}_{2} \mathrm{O}(100 \mathrm{~mL})$ and washed with EtOAc $(3 \times 150 \mathrm{~mL})$. The combined organic layers were dried over $\mathrm{Na}_{2} \mathrm{SO}_{4}$ and the solvent was removed under 
reduced pressure to obtain a light yellow oil $(5.04 \mathrm{~g}, 80 \%) .{ }^{1} \mathrm{H} \mathrm{NMR}\left(\mathrm{CDCl}_{3}\right): 1.20(3 \mathrm{H}, \mathrm{t}$, $J=7.1 \mathrm{~Hz}), 1.35-1.45(1 \mathrm{H}, \mathrm{m}) 1.53-1.55(1 \mathrm{H}, \mathrm{m}), 1.64-1.68(3 \mathrm{H}, \mathrm{m}), 1.93-2.01(2 \mathrm{H}, \mathrm{m})$, $2.39(1 \mathrm{H}, \mathrm{q}$ of d, $J=12.3,3.7 \mathrm{~Hz}), 2.82(3 \mathrm{H}, \mathrm{s}), 3.08(1 \mathrm{H}, \mathrm{m}), 3.75(1 \mathrm{H}, \mathrm{d}$ of $\mathrm{t}, J=12.0$, $4.0 \mathrm{~Hz}), 3.78(3 \mathrm{H}, \mathrm{s}), 4.00-4.12(2 \mathrm{H}, \mathrm{m}), 6.27(1 \mathrm{H}, \mathrm{m}), 6.34(1 \mathrm{H}, \mathrm{d}, J=8.3 \mathrm{~Hz}), 7.15(1 \mathrm{H}$, $\mathrm{t}, J=8.2 \mathrm{~Hz}) .{ }^{13} \mathrm{C}$ NMR $\left(\mathrm{CDCl}_{3}\right): 14.28,21.45,26.69,26.95,28.83,32.45,42.09,55.27$, 59.13, 60.20, 98.92, 100.67, 105.32, 129.95, 150.86, 160.97, 174.55. HRMS (ESI): m/z $\left[\mathrm{M}+\mathrm{H}^{+}\right]$calculated for $\mathrm{C}_{17} \mathrm{H}_{25} \mathrm{NO}_{3}: 292.1907$; observed 292.1894.

Synthesis of compound 2.40. A mixture of compound $2.44(5.03 \mathrm{~g}, 17.26 \mathrm{mmol})$ and $\mathrm{KOH}(2.42 \mathrm{~g}, 43.14 \mathrm{mmol})$ in $15 \mathrm{~mL} \mathrm{MeOH}$ were stirred at $\mathrm{rt}$ for $1 \mathrm{~h}$. An additional 5 equiv of $\mathrm{KOH}(4.84 \mathrm{~g})$ were added and stirring was continued overnight. After the reaction was complete, $\mathrm{MeOH}$ was removed under vacuum. The residue was poured into $\mathrm{CH}_{2} \mathrm{Cl}_{2}$ and diluted with $\mathrm{H}_{2} \mathrm{O}$. The solution was acidified to $\mathrm{pH} 3$ via slow addition of 1 $\mathrm{N} \mathrm{HCl}$. The reaction mixture was extracted with $\mathrm{CH}_{2} \mathrm{Cl}_{2}(3 \times 150 \mathrm{~mL})$ and the combined organic layers were dried with $\mathrm{Na}_{2} \mathrm{SO}_{4}$. The solvent was removed in vacuo to afford a brown oil (crude yield: $4.5 \mathrm{~g}, 99 \%) .{ }^{1} \mathrm{H} \mathrm{NMR}\left(\mathrm{CDCl}_{3}\right): 1.34-143(2 \mathrm{H}, \mathrm{m}), 1.34-1.56(2 \mathrm{H}$, m) $1.74-1.82(4 \mathrm{H}, \mathrm{m}), 2.31-2.35(1 \mathrm{H}, \mathrm{m}), 2.58(1 \mathrm{H}, \mathrm{t}$ of d, $J=11.6,3.8 \mathrm{~Hz}), 2.77(3 \mathrm{H}, \mathrm{s})$, $3.58(1 \mathrm{H}, \mathrm{t}$ of d, $J=11.4,3.6 \mathrm{~Hz}), 3.80(3 \mathrm{H}, \mathrm{s}), 6.44(1 \mathrm{H}, \mathrm{d}$ of d of d , $J=8.2,2.3,0.6$ $\mathrm{Hz}), 6.54(1 \mathrm{H}, \mathrm{t}, J=2.3 \mathrm{~Hz}), 6.60(1 \mathrm{H}, \mathrm{d}$ of d, $J=5.3,4.8 \mathrm{~Hz}), 7.15(1 \mathrm{H}, \mathrm{t}, J=8.2 \mathrm{~Hz})$. ${ }^{13} \mathrm{C} \mathrm{NMR}\left(\mathrm{CDCl}_{3}\right): 25.22,25.57,26.76,29.43,31.86,46.12,55.39,63.07,103.97,105.29$, 110.12, 129.86, 151.29, 160.84, 177.78. HRMS (ESI): $\mathrm{m} / \mathrm{z}\left[\mathrm{M}+\mathrm{H}^{+}\right]$calculated for $\mathrm{C}_{15} \mathrm{H}_{22} \mathrm{NO}_{3}$ : 264.1594; observed 264.1582. 
Synthesis of compound 2.34. A mixture of compound $2.40(0.5 \mathrm{~g}, 1.9 \mathrm{mmol})$ and polyphosphoric acid $(6.3 \mathrm{~g})$ was heated to $120{ }^{\circ} \mathrm{C}$ for $20 \mathrm{~min}$. The reaction was cooled to rt and the solution neutralized to $\mathrm{pH} 7-8$ with $15 \%$ aq. $\mathrm{NaOH}$. The reaction mixture was extracted with EtOAc and the combined organic layers were dried over $\mathrm{Na}_{2} \mathrm{SO}_{4}$ and the solvent removed in vacuo. The residue was purified by column chromatography on $\mathrm{SiO}_{2}$ using Hexane:EtOAc 8:1 as the eluent to compound 2.34 as a yellow solid. (75.58 mg, 16\%). ${ }^{1} \mathrm{H} \mathrm{NMR}\left(\mathrm{CDCl}_{3}\right): 1.15-1.34(3 \mathrm{H}, \mathrm{m}), 1.42-1.51(1 \mathrm{H}, \mathrm{m}), 1.82-1.85(1 \mathrm{H}, \mathrm{m}), 1.89-$ 1.91(1H, m), 2.22-2.29 (1H, m), 2.34-2.38 (1H, m), 2.42-2.47 (1H, m), $2.90(3 \mathrm{H}, \mathrm{s}), 3.06$ $(1 \mathrm{H}, \mathrm{d}$ of d of d, $J=13.1,11.3,4.1 \mathrm{~Hz}), 3.84(3 \mathrm{H}, \mathrm{s}), 6.25(1 \mathrm{H}, \mathrm{d}, J=2.2 \mathrm{~Hz}), 6.36(1 \mathrm{H}$, $\mathrm{d}$ of $\mathrm{d}, J=8.7,2.3 \mathrm{~Hz}), 7.89(1 \mathrm{H}, \mathrm{d}, J=8.7 \mathrm{~Hz}) .{ }^{13} \mathrm{C} \mathrm{NMR}\left(\mathrm{CDCl}_{3}\right): 24.76,24.78,24.87$, $31.62,32.79,50.36,55.43,62.12,97.92,104.37,114.69,130.34,154.85,165.49,194.33$. HRMS (ESI): $\mathrm{m} / \mathrm{z}\left[\mathrm{M}+\mathrm{H}^{+}\right]$calculated for $\mathrm{C}_{15} \mathrm{H}_{21} \mathrm{NO}_{3}: 246.1489$; observed 246.1482

Synthesis of compound 2.33. Under Ar, to a solution of compound $2.34(1 \mathrm{~g}$, $4.08 \mathrm{mmol})$ in $12.5 \mathrm{~mL}$ of anhydrous $\mathrm{Et}_{2} \mathrm{O}$ was added $\mathrm{LiAlH}_{4}(464 \mathrm{mg}, 12.23 \mathrm{mmol})$ portion-wise slowly. Once evolution of $\mathrm{H}_{2}$ ceased, $12.5 \mathrm{~mL}$ dry toluene was added and the reaction heated at reflux $\left(120^{\circ} \mathrm{C}\right)$ for $2 \mathrm{~h}$. The mixture was cooled to $0{ }^{\circ} \mathrm{C}$ and followed by dropwise consecutive additions of $0.5 \mathrm{~mL}$ of $\mathrm{H}_{2} \mathrm{O}, 0.5 \mathrm{~mL}$ of $15 \% \mathrm{NaOH}$ and $1.5 \mathrm{~mL}$ of $\mathrm{H}_{2} \mathrm{O}$. The resultant precipitate was removed by vacuum filtration, washed with $60 \mathrm{~mL} \mathrm{CH} \mathrm{Cl}_{2}$. The filtrate was concentrated in vacuo to afford compound $\mathbf{2 . 3 3}$ as a light yellow solid (929 mg, 99\%). ${ }^{1} \mathrm{H}$ NMR $\left(\mathrm{CDCl}_{3}\right): 1.07-1.21(2 \mathrm{H}, \mathrm{m}), 1.24-1.41(2 \mathrm{H}$, m), 1.51-1.61 $(1 \mathrm{H}, \mathrm{m}), 1.71-1.75(1 \mathrm{H}, \mathrm{m}), 1.83-1.88(2 \mathrm{H}, \mathrm{m}), 2.26-2.30(1 \mathrm{H}, \mathrm{m}), 2.37-$ $2.45(1 \mathrm{H}, \mathrm{m}), 2.37-2.45(1 \mathrm{H}, \mathrm{m}), 2.52(1 \mathrm{H}, \mathrm{d}$ of d, $J=15.1,4.2 \mathrm{~Hz}), 2.68(1 \mathrm{H}, \mathrm{t}$ of d, $J=$ 
10.6, $3.6 \mathrm{~Hz}), 2.9(3 \mathrm{H}, \mathrm{s}), 3.77(3 \mathrm{H}, \mathrm{s}), 6.17(1 \mathrm{H}, \mathrm{d}$ of d, $J=8.1,2.4 \mathrm{~Hz}), 6.22(1 \mathrm{H}, \mathrm{d}, J=$ $2.4 \mathrm{~Hz}), 6.81(1 \mathrm{H}, \mathrm{d}, J=8.0 \mathrm{~Hz}) .{ }^{13} \mathrm{C} \mathrm{NMR}\left(\mathrm{CDCl}_{3}\right): 25.30,25.84,32.44,33.03,34.84$, $35.99,39.28,55.34,63.47,99.44,100.73,116.63,128.59,148.47,159.30$. HRMS (ESI): $\mathrm{m} / \mathrm{z}\left[\mathrm{M}+\mathrm{H}^{+}\right]$calculated for $\mathrm{C}_{15} \mathrm{H}_{22} \mathrm{NO}: 232.1696$; observed 232.1684.

Synthesis of compound 2.32. Under Ar, compound 2.33 ( $1 \mathrm{~g}$, $4.32 \mathrm{mmol})$ was dissolved in glacial $\mathrm{AcOH}(2.5 \mathrm{~mL}), 48 \%$ aq. $\mathrm{HBr}(3.03 \mathrm{~mL}, 26.8 \mathrm{mmol})$ was added and the mixture heated at reflux $\left(118{ }^{\circ} \mathrm{C}\right)$ overnight. After cooling, the solution was neutralized to $\mathrm{pH} 5-6$ with $30 \%$ aq. $\mathrm{NaOH}$. The aqueous phase was extracted with $\mathrm{CH}_{2} \mathrm{Cl}_{2}(3 \times 100 \mathrm{~mL})$ and the combined organic layers were washed with brine and dry over $\mathrm{Na}_{2} \mathrm{SO}_{4}$. The solvent was removed under reduced pressure to afford compound $\mathbf{2 . 3 2}$ as a brown solid (938 mg, 100\%). ${ }^{1} \mathrm{H} \mathrm{NMR}\left(\mathrm{CDCl}_{3}\right): 1.06-1.20(2 \mathrm{H}, \mathrm{m}), 1.23-1.41(2 \mathrm{H}$, m), 1.50-1.60 $(1 \mathrm{H}, \mathrm{m}), 1.71-1.74(1 \mathrm{H}, \mathrm{m}), 1.83-1.87(2 \mathrm{H}, \mathrm{m}), 2.25-2.29(1 \mathrm{H}, \mathrm{m}), 2.36-$ $2.42(1 \mathrm{H}, \mathrm{m}), 2.50(1 \mathrm{H}, \mathrm{d}$ of d, $J=15.1,4.2 \mathrm{~Hz}), 2.68(1 \mathrm{H}, \mathrm{t}$ of d, , $J=10.6,3.6 \mathrm{~Hz}), 2.87$ $(3 \mathrm{H}, \mathrm{s}), 6.06(1 \mathrm{H}, \mathrm{d}$ of d, $J=7.9,2.4 \mathrm{~Hz}), 6.14(1 \mathrm{H}, \mathrm{d}, J=2.3 \mathrm{~Hz}), 6.74(1 \mathrm{H}, \mathrm{d}, J=7.8$ $\mathrm{Hz}) .{ }^{13} \mathrm{C}$ NMR $\left(\mathrm{CDCl}_{3}\right): 25.30,25.83,32.40,33.02,34.83,35.87,39.27,63.38,99.83$, 102.71, 116.35, 128.83, 148.64, 154.99. HRMS (ESI): $\mathrm{m} / \mathrm{z}\left[\mathrm{M}+\mathrm{H}^{+}\right]$calculated for $\mathrm{C}_{14} \mathrm{H}_{20} \mathrm{NO}$ : 218.1539; observed 218.1522.

Synthesis of compound 2.45. In a $2 \mathrm{~mL}$ microwave tube, compound 2.32 (108 $\mathrm{mg}, 0.499 \mathrm{mmol})$ and methyl 4-(4-formylphenyl)benzoate $(60 \mathrm{mg}, 0.25 \mathrm{mmol})$ were dissolved in $1 \mathrm{~mL} \mathrm{CH} \mathrm{Cl}_{2}$. The solvent was purged using an $\mathrm{N}_{2}$ stream. The reaction mixture was heated in microwave reactor at $150{ }^{\circ} \mathrm{C}$ for $10 \mathrm{~min}$. The mixture was dissolved in $\mathrm{CH}_{2} \mathrm{Cl}_{2}: \mathrm{MeOH}$ (95:5, $0.5 \mathrm{~mL}$ ) followed by addition of tetrachloro-1,4- 
benzoquinone (92.1 mg, $0.375 \mathrm{mmol}$ ) and vortexed at $1000 \mathrm{rpm}$ for $15 \mathrm{~min}$. The solvent was removed using an $\mathrm{N}_{2}$ stream. The mixture was separated via a short $\mathrm{SiO}_{2}$ plug using $\mathrm{CH}_{2} \mathrm{Cl}_{2}: \mathrm{MeCN}$ 1:1, followed by $\mathrm{CH}_{2} \mathrm{Cl}_{2}: \mathrm{MeOH} 97: 3$ as the eluent to give a dark purple solid (67.3 mg, 42\%). ${ }^{1} \mathrm{H}$ NMR(DMSO) : 1.11-1.47 (12H, m), 1.66-1.67 (2H, m), 1.77$1.85(4 \mathrm{H}, \mathrm{m}), 2.34-2.47(4 \mathrm{H}, \mathrm{m}), 2.66(2 \mathrm{H}, \mathrm{d}, J=14.2 \mathrm{~Hz}), 3.21(6 \mathrm{H}, \mathrm{s}), 3.91(3 \mathrm{H}, \mathrm{s})$, $6.93(2 \mathrm{H}, \mathrm{s}), 6.99(2 \mathrm{H}, \mathrm{s}), 7.58-7.62(2 \mathrm{H}, \mathrm{m}), 7.99(2 \mathrm{H}, \mathrm{d}$ of d, $J=8.6,2.1 \mathrm{~Hz}), 8.05(2 \mathrm{H}$, $\mathrm{d}$ of d, $J=8.5,2.5 \mathrm{~Hz}), 8.11(2 \mathrm{H}, \mathrm{d}$ of d, $J=8.5,1.1 \mathrm{~Hz}) .{ }^{13} \mathrm{C}$ NMR (DMSO): 24.70, $24.77,30.67,31.36,33.47,35.60,38.16,52.27,63.81,96.28,112.75,126.50,127.17$, $127.35,129.05,129.97,140.07,143.49,154.90,156.48,156.51,165.99$. HRMS (ESI): $\mathrm{m} / \mathrm{z}\left[\mathrm{M}^{+}\right]$calculated for $\mathrm{C}_{43} \mathrm{H}_{45} \mathrm{~N}_{2} \mathrm{O}_{3}{ }^{+}:$637.3425; observed 637.3381.

Synthesis of compound 2.46. Compound 2.45 (67 $\mathrm{mg}, 0.105 \mathrm{mmol})$ was dissolved in MeOH:THF: $\mathrm{H}_{2} \mathrm{O}$ (5:3:1, $\left.2.7 \mathrm{~mL}\right)$ and $\mathrm{LiOH}(12.58 \mathrm{mg}, 0.525 \mathrm{mmol})$ was added. The reaction was stirred at $\mathrm{rt}$ overnight. After the reaction was complete, the residue was dissolved in $\mathrm{CH}_{2} \mathrm{Cl}_{2}: \mathrm{H}_{2} \mathrm{O}(1: 1,2 \mathrm{~mL})$, and $1 \mathrm{~N} \mathrm{HCl}$ was slowly added to reach $\mathrm{pH}$ 5. The aqueous layer was extracted with $\mathrm{CH}_{2} \mathrm{Cl}_{2}(3 \times 5 \mathrm{~mL})$, and the combined organic layers were dried over $\mathrm{Na}_{2} \mathrm{SO}_{4}$. The solvent was removed in vacuo to furnish a purple solid (59.42 mg, 91\%). ${ }^{1} \mathrm{H} \mathrm{NMR}\left(\mathrm{CD}_{3} \mathrm{OD}\right): 1.14-1.48(12 \mathrm{H}, \mathrm{m}), 1.66-1.69(3 \mathrm{H}, \mathrm{m})$, 1.80-1.86 (3H, m), 2.34-2.48 (4H, m), $2.67(2 \mathrm{H}, \mathrm{d}, J=13.6 \mathrm{~Hz}), 3.21(6 \mathrm{H}, \mathrm{s}), 6.9(2 \mathrm{H}, \mathrm{s})$, $7.0(2 \mathrm{H}, \mathrm{s}), 7.6(2 \mathrm{H}, \mathrm{d}, J=7.6 \mathrm{~Hz}), 7.96(2 \mathrm{H}, \mathrm{d}, J=8.3 \mathrm{~Hz}), 8.05(2 \mathrm{H}, \mathrm{d}, J=8.2 \mathrm{~Hz})$, $8.10(2 \mathrm{H}, \mathrm{d}, J=8.4 \mathrm{~Hz}) .{ }^{13} \mathrm{C}$ NMR $\left(\mathrm{CD}_{3} \mathrm{OD}\right): 24.71,24.77,30.68,31.36,33.48,35.61$, $38.17,63.81,96.27,112.79,126.52,127.00,127.31,130.11,131.86,140.32,143.00$, 
154.30, 154.92, 156.53, 167.09. HRMS (ESI): $\mathrm{m} / \mathrm{z}\left[\mathrm{M}^{+}\right]$calculated for $\mathrm{C}_{42} \mathrm{H}_{43} \mathrm{~N}_{2} \mathrm{O}_{3}{ }^{+}$: 623.3268; observed 623.3287.

Synthesis of compound 2.8. Compound 2.46 ( $8 \mathrm{mg}, 0.013 \mathrm{mmol}$ ) was dissolved in $0.2 \mathrm{~mL}$ of anhydrous THF. EDAC (3.69 $\mathrm{mg}, 0.019 \mathrm{mmol}$ ) was added in one portion followed by the addition of NHS $(1.77 \mathrm{mg}, 0.015 \mathrm{mmol})$. The reaction was stirred at $\mathrm{rt}$ for $4 \mathrm{~h}$. Another 5 equiv $\operatorname{EDAC}(12.3 \mathrm{mg}, 0.063 \mathrm{mmol})$ were added and the reaction stirred at $\mathrm{rt}$ overnight. The reaction mixture was poured into $5 \mathrm{~mL}$ of $50 \mathrm{mM} \mathrm{pH6}$ phosphate buffer, and extracted with $\mathrm{CH}_{2} \mathrm{Cl}_{2}(3 \times 5 \mathrm{~mL})$. The combined organic layers were washed with brine and dried over $\mathrm{Na}_{2} \mathrm{SO}_{4}$ and the solvent evaporated in vacuo. The mixture was separated via a short $\mathrm{SiO}_{2}$ plug using $\mathrm{CH}_{2} \mathrm{Cl}_{2}: \mathrm{MeCN}$ 1:1 then DCM:MeOH 96:4 to afford the target compound $\mathbf{2 . 8}$ as a purple solid $(7.68 \mathrm{mg}, 83 \%) .{ }^{1} \mathrm{H}$ $\operatorname{NMR}\left(\mathrm{CDCl}_{3}\right): 1.13-1.32(8 \mathrm{H}, \mathrm{m}), 1.36-1.42(2 \mathrm{H}, \mathrm{m}), 1.47-1.57(2 \mathrm{H}, \mathrm{m}), 1.74(2 \mathrm{H}, \mathrm{d}, J=$ $12.3 \mathrm{~Hz}), 1.84(2 \mathrm{H}, \mathrm{d}, J=12.3 \mathrm{~Hz}), 1.92(2 \mathrm{H}, \mathrm{d}, J=13.1 \mathrm{~Hz}), 2.42-2.49(4 \mathrm{H}, \mathrm{m}), 2.60$ $(2 \mathrm{H}, \mathrm{d}$ of d, $J=15.2,2.6 \mathrm{~Hz}), 2.93(4 \mathrm{H}, \mathrm{s}), 3.12-3.18(2 \mathrm{H}, \mathrm{m}), 3.24(6 \mathrm{H}, \mathrm{s}), 6.82(2 \mathrm{H}, \mathrm{s})$, $6.94(2 \mathrm{H}, \mathrm{s}), 7.49(2 \mathrm{H}, \mathrm{d}, J=8.2 \mathrm{~Hz}), 7.84(2 \mathrm{H}, \mathrm{d}, J=8.5 \mathrm{~Hz}), 7.88(2 \mathrm{H}, \mathrm{d}, J=8.3 \mathrm{~Hz})$, $8.26(2 \mathrm{H}, \mathrm{d}, J=8.5 \mathrm{~Hz}) .{ }^{13} \mathrm{C} \mathrm{NMR}\left(\mathrm{CDCl}_{3}\right): 25.16,25.25,25.84,29.76,31.51,32.04$, $34.63,36.20,38.85,64.80,96.96,113.59,124.70,126.83,126.85,126.91,127.66,127.87$, $127.91,127.95,130.16,130.26,130.36,131.46,132.68,141.10,146.13,154.62,155.56$, 157.24, 157.26, 161.70, 169.39. HRMS (ESI): $\mathrm{m} / \mathrm{z}\left[\mathrm{M}^{+}\right]$calculated for $\mathrm{C}_{46} \mathrm{H}_{46} \mathrm{~N}_{3} \mathrm{O}_{5}{ }^{+}$: 720.3426; observed 720.3432 . 


\subsection{Conclusion}

Molecular simulations guided the design of geometrically rigid fluorophores. A series of well-defined rhodamine analogs $(\mathbf{2 . 6}, \mathbf{2 . 7}$ and 2.8) have thus been synthesized to serve as the optical components of cationic drug-gentamicin conjugates. Inflexible Texas

Red, 2.6, was synthesized in four steps in $13 \%$ overall yield. A direct condensation of hydroxyl-quinoline and methyl 4-(4-formylphenyl)benzoate afforded the precursor to target 2.7. Several attempts were evaluated to prepare the key intermediate to rhodamine 2.8. An alternative approach including reductive amination and intramolecular FriedelCrafts acylation was successful. The overall yield for $\mathbf{2 . 7}$ (6 steps) and $\mathbf{2 . 8}$ (9 steps) are $17 \%$ and 3\%, respectively. Rhodamine derivatives, 2.6, 2.7 and 2.8 in DPS/DMSO exhibited signs of aggregation, but in $\mathrm{MeOH}$ exhibited overall similar spectral properties compared to $\mathbf{2 . 2}$ has sulfonic groups improve solubility. 


\subsection{Future Work}

- Continued systematic changes to fluorophore dimensions while keeping the rigid linker.

- Synthesis of fluorophores with semi-flexible (glycol) and flexible (alkyl) linker.

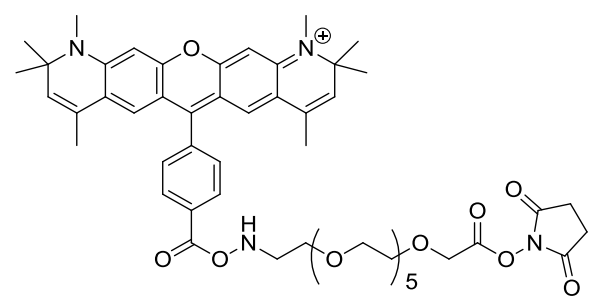

(semi-flexible)

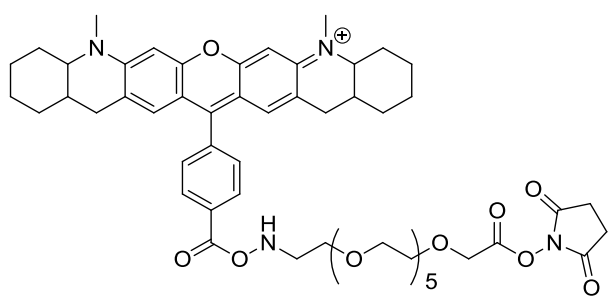

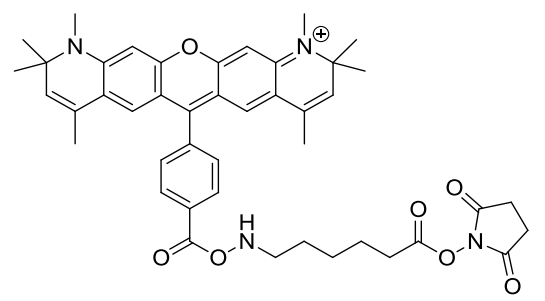

(flexible)

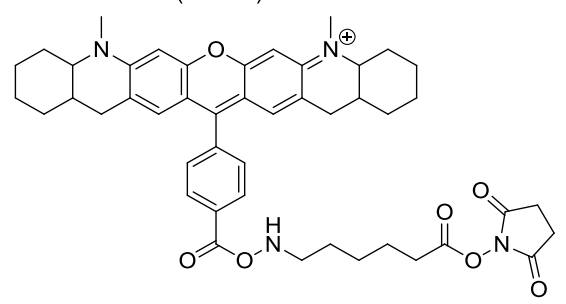

A series of gentamicin-fluorophore conjugates containing biaryl (inflexible), glycol (semiflexible) or alkyl (flexible) linkers will enable library generation and ensuing structure-activity relationship (SAR) studies to investigate if changing the fluorophore itself or linkers can help preserve fluorescence properties in cellular studies and complement the rigid analogs in defining channel properties. 


\section{CHAPTER 3 THE UTILITY OF RIGID FLUOROPHORE-GENTAMICIN CONJUGATES IN ZEBRAFISH AND KIDNEY CELL TRAFFICKING STUDIES}

\subsection{Introduction}

AGs are essential for treating life-threatening bacterial sepsis, yet induce acute nephrotoxicity and permanent deafness. In order to have a better understanding of how AGs enter ear hair cells and kidney cells, GTTR 2.1 has been mainly used to study the mechanism of drug uptake. Recently, a candidate aminoglycoside transporter (sodiumglucose transporter-2; SGLT2) was identified that might be associated with kidney cytotoxicity. ${ }^{72}$ Molecular simulations (Figure 2.4) show that GTTR has a flexible linker that promotes conjugate folding thereby reducing its cross sectional diameter to pass through non-selective cation channels. A series of rigid and extended rhodamine derivatives (2.6, 2.7 and 2.8) have been used to conjugate to gentamicin $(2.3$ and $2.4 ; 2.5$ is in progress). The conjugates were prepared at OHSU by Meiyan Jiang in Prof. Steyger's group (Figure 3.1). These new analogs can serve as molecular rulers to determine the maximum dilated MET channel or transporter pore size, to better inform the prevention of cochlear hair cell uptake to preserve lifelong auditory function.

\subsection{Synthesis of gentamin conjugates}

Conjugates (2.1, 2.3 and 2.4) were prepared using similar reaction condition as shown in Figure 3.1. Conjugation of the activated fluorophore (2.2, 2.6 and 2.7) to gentamicin was carried out at $\mathrm{pH} 10$ in aqueous media at $\mathrm{rt}$ (using a molar ratio of fluorophore:gentamicin 1:100 in order to ensure that only one molecule of the 
fluorophore is conjugated to one molecule of gentamicin) with $60 \%, 25 \%$ and $10 \%$ yield, respectively.

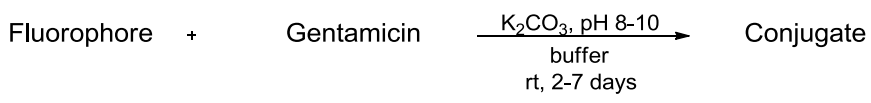

Conjugates
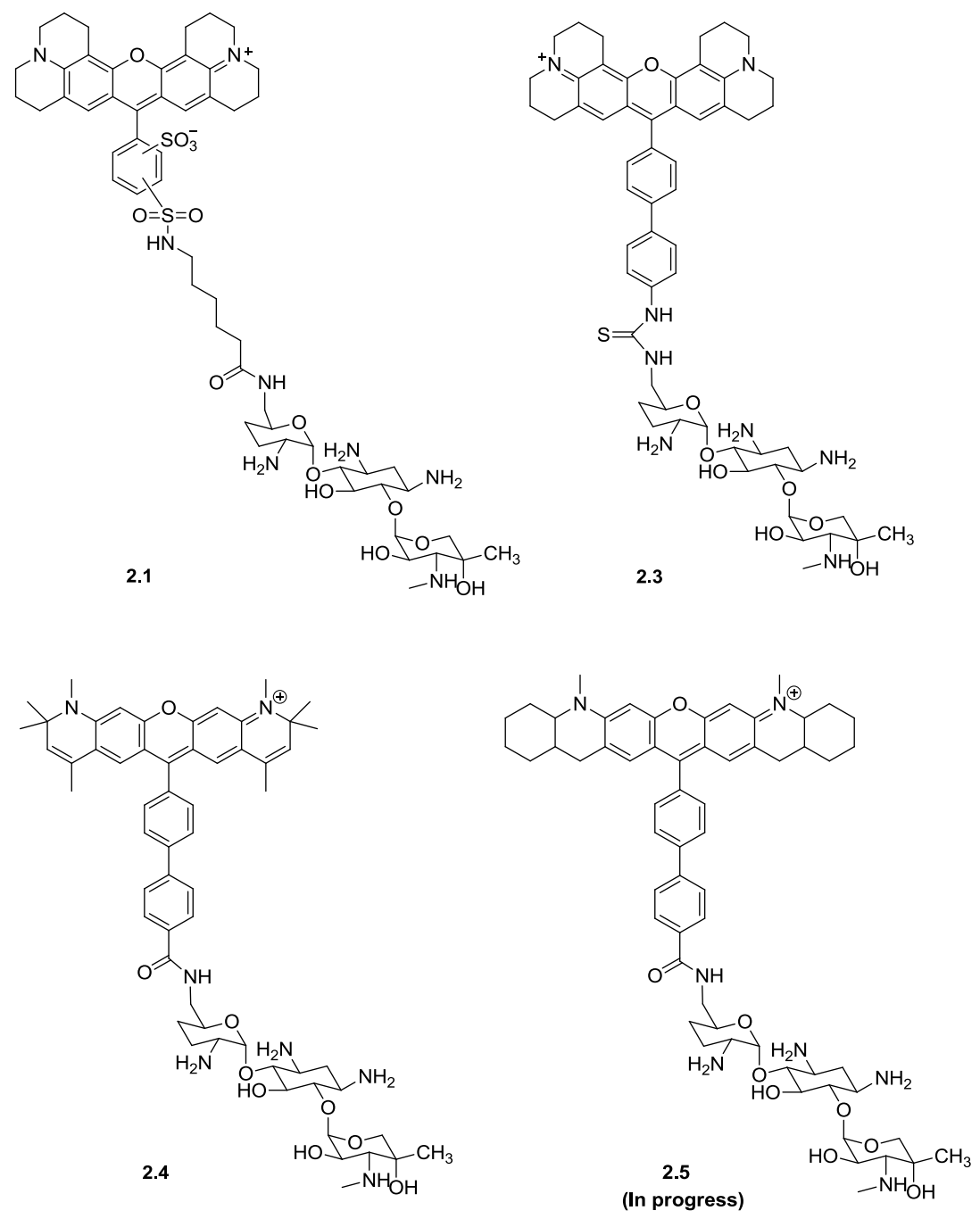

Figure 3.1 Fluorophores-gentamicin conjugates

46 


\subsection{Cell Imaging Studies}

MDCT (Mouse Distal Convoluted Tubule Cell Line) cells and zebrafish were used to study cellular uptake with conjugates $\mathbf{2 . 3}$ and $\mathbf{2 . 4}$ to evaluate the maximum permeation/dilation diameter of aminoglycoside-permissive channels and aminoglycoside transporters in hair cells and kidney cells.

\subsubsection{MDCT cell}

MDCT cells were chosen as an in vitro model of strial cells due to their common ion regulatory functions. MDCT cells were incubated with $5 \mu \mathrm{g} / \mathrm{ml}$ of each conjugate or the free fluorophores. As shown in Figure 3.2, there is a strong bright cytoplasmic and intra-nuclear fluorescence of MDCT cells (A1). MDCT cellular uptake of gentamicin diminishes with the increase in the cross-sectional diameter of the fluorophore. (Fluorescence intensity: $2.1>2.3>\mathbf{2 . 4}$ ). This result suggests that larger diameter fluorophores may potentially prevent kidney cell gentamicin uptake. There is no uptake of free fluorophore as shown in B1, B2 and B3.

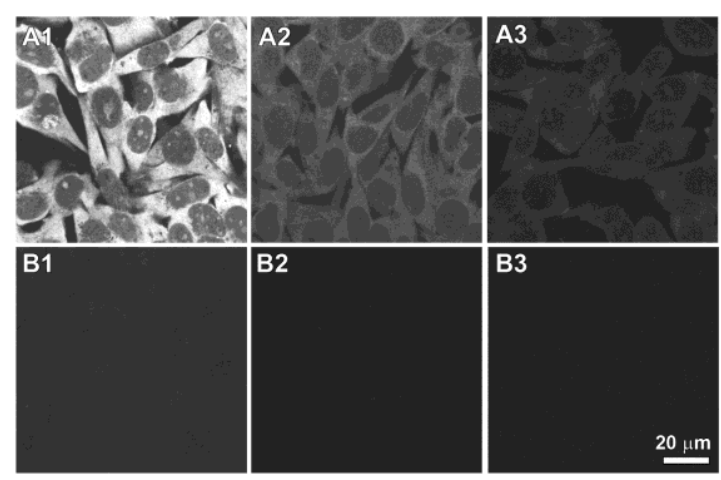

Figure 3.2 Cellular uptake of MDCT cells.

MDCT cells were incubated with $5 \mu \mathrm{g} / \mathrm{ml}$ conjugates. 2.1 (A1), 2.3 (A2) and 2.4 (A3); free fluorophores 2.2 (B1), 2.6 (B2) and 2.7 (B3) in PBS for $30 \mathrm{~s}$, then fixation with 4\% paraformaldehyde containing $0.5 \%$ Triton $X-100$ for $30 \mathrm{~min}$. Scale bar $=20 \mu \mathrm{m}$ 


\subsubsection{Zebrafish}

Zebrafish are used as an ideal model for drug-screening assays due to its small size, optical transparency and high proliferation. ${ }^{73}$ Also, they possess mechanosensitive hair cells on the surface of their body on the lateral line (sensory) system, sharing structural and molecular similarities with mammalian inner ear hair cells. They are also sensitive to aminoglycosides antibiotics. ${ }^{74}$ The mariner zebrafish mutants have defective myosin VIIa that is critical for mechanotransduction by hair cells, and display defects in balance and acoustic startle reflexes owing to peripheral defects in the auditory/vestibular system. $^{75}$

As shown in Figure 3.3, zebrafish were treated with $1 \mu \mathrm{g} / \mathrm{ml}$ conjugates or free fluorophores for 10 min before fixation. Zebrafish neuromasts treated with $\mathbf{2 . 3}$ and $\mathbf{2 . 4}$ had significantly reduced hair cell uptake of gentamicin as compared to neuromasts treated with 2.1 only (A1-C1). These results indicate that the molecular modification of fluorophores reduces conjugate permeation through the MET channel and could prevent hair cell cytotoxicity. Based on the cross-sectional diameter of $\mathbf{2 . 3}$ and 2.4, we can assume that the dilated MET channel pore size is approximately between $1.44 \mathrm{~nm}$ and $1.56 \mathrm{~nm}$. Hair cell uptake was reduced in mariner zebrafish neuromasts compare to wildtype zebrafish. The myosin VIIa mutant zebrafish mariner with defective mechanotransduction is protected against hair cell damage caused by gentamicin (A1-F1). There is no free fluorophore uptake by wild-type and mariner zebrafish (G1-L1). 


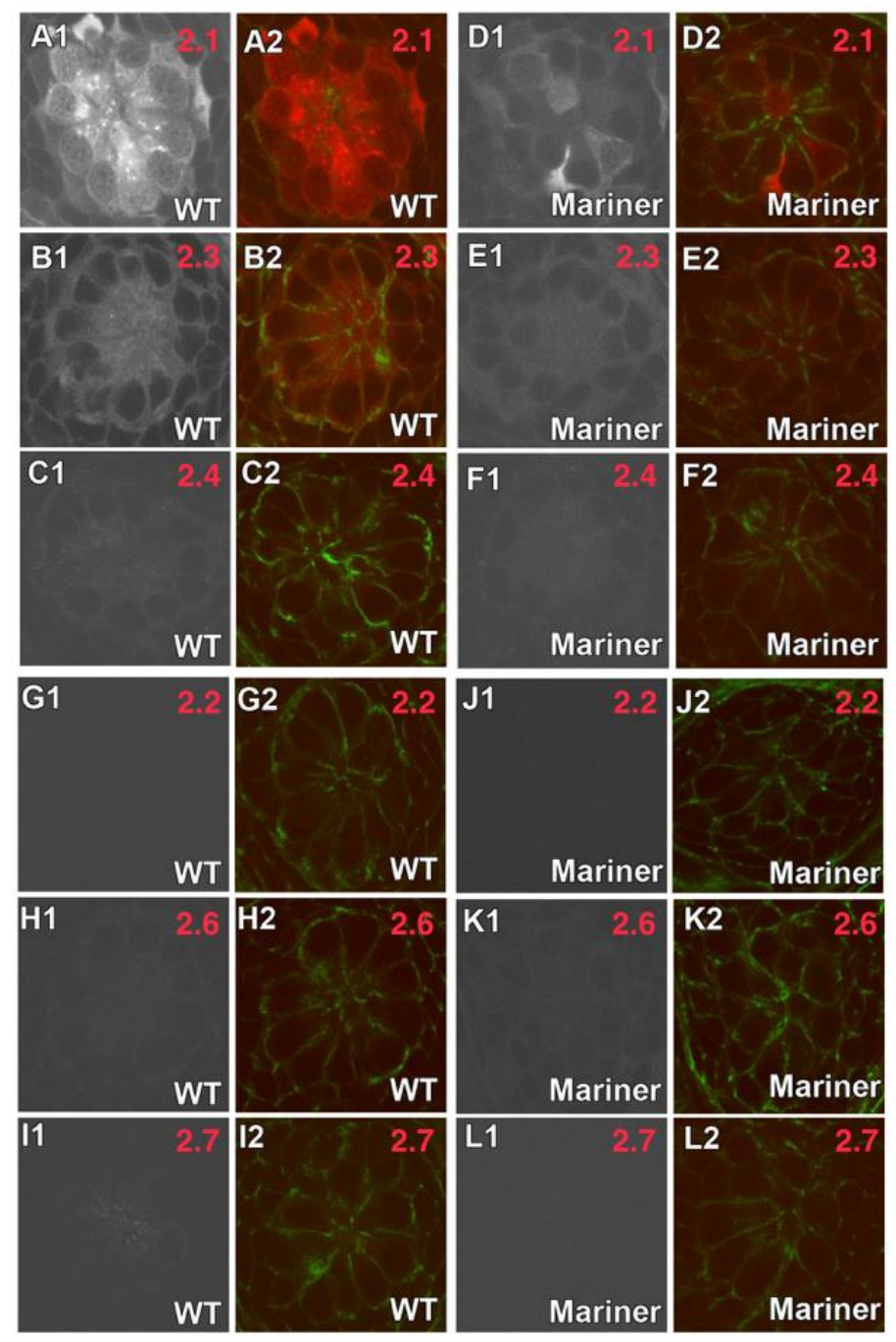

Figure 3.3 Cellular uptake with $1 \mu \mathrm{g} / \mathrm{ml}$ conjugates and free fluorophores by wild-type and mariner zebrafish.

Neuromast hair cells can be identified by phalloidin-labeled (green) cuticular plates. 2.1 uptake (red) by hair cells is preferentially localized within the cytoplasm. A1-A2: Neuromast hair cells of wild-type larva incubated with $\mathbf{2 . 1}$ for $10 \mathrm{~min}$ display robust fluorescence. B1-B2: Neuromast hair cells of wild-type larva incubated with 2.3 for 10 min display less fluorescence intensity than 2.1. C1-C2: Neuromast hair cells of wildtype larva incubated with $\mathbf{2 . 4}$ for 10 min display almost no fluorescence. D1-F2: 2.1, 2.3, 2.4 uptake in the neuromast hair cells of mariner larva are much less than that in wildtype larva. G1-I2: Neuromast hair cells of wild-type larva treated with the same dose of unconjugated $\mathbf{2 . 2}, \mathbf{2 . 6}$ or $\mathbf{2 . 7}$ for $10 \mathrm{~min}$ display negligible fluorescence. J1-L2: Neuromast hair cells of mariner larva treated with the same dose of unconjugated 2.2, 2.6 or $\mathbf{2 . 7}$ for 10 min display negligible fluorescence. 


\subsection{Experimental Section}

Synthesis of Gentamicin-Texas Red conjugate, 2.1. An excess of gentamicin (Sigma, MO, USA) in $0.1 \mathrm{M}$ potassium carbonate ( $\mathrm{pH}$ 10) was mixed with TR-SE 2.2 (Invitrogen, CA) to minimize the possibility of over-labeling individual gentamicin molecules with more than one TR molecule, and to preserve the polycationic nature of the conjugate. After conjugation, reversed phase chromatography, using C-18 columns (Grace Discovery Sciences, IL), was used to purify GTTR from unconjugated gentamicin, and potential contamination by unreacted TR. The purified GTTR conjugate was aliquoted, lyophilized, and stored desiccated in the dark at $-20{ }^{\circ} \mathrm{C}$ until use.

Synthesis of 2.6-gentamicin conjugate, 2.3. An excess of gentamicin (Sigma, MO, USA) in $0.1 \mathrm{M}$ potassium carbonate $(\mathrm{pH} 8)$ was mixed with $\mathbf{2 . 6}$ (gentamicin: $\mathbf{2 . 6}=$ 100:1). The conjugation mixture reacted at $\mathrm{rt}$ for 2 days. After conjugation, chromatography using alumina columns and acetonitrile was used to purify $\mathbf{2 . 3}$ from unconjugated gentamicin, and potential contamination by unreacted 2.6. The purified $\mathbf{2 . 3}$ was aliquoted, lyophilized, and stored desiccated in the dark at $-20{ }^{\circ} \mathrm{C}$ until use.

Synthesis of 2.7-gentamicin conjugate, 2.4. An excess of gentamicin (Sigma, MO, USA) in $0.1 \mathrm{M}$ potassium carbonate $(\mathrm{pH} 9)$ was mixed with 2.7 (gentamicin: $\mathbf{2 . 7}=$ 100:1). The conjugation mixture was left to react at $\mathrm{rt}$ for 7 days. After conjugation, reverse phase chromatography, using C-18 columns (Grace Discovery Sciences, IL), was used to purify 2.4 from unconjugated gentamicin, and potential contamination by unreacted 2.7. The purification procedure is the same as GTTR purification. The purified 
2.4 conjugate was aliquoted, lyophilized, and stored desiccated in the dark at $-20{ }^{\circ} \mathrm{C}$ until use.

Gentamicin uptake by MDCT cells. MDCT cells plated on 8-well chambered coverslips were washed with cell medium twice, incubated with $5 \mu \mathrm{g} / \mathrm{ml}$ conjugates or free fluorophores in PBS for $30 \mathrm{~s}$ at $\mathrm{rt}$ to preclude endocytosis, then washed with PBS three times to remove conjugate from extracellular media prior to fixation with $4 \%$ paraformaldehyde containing $0.5 \%$ Triton X-100 for $30 \mathrm{~min}$. The cellular distribution of conjugate fluorescence was examined using a Bio-Rad 1024 ES scanning laser system. For each individual set of images to be compared, the same confocal settings were used, with two acquisition images per well, two wells per experimental condition, and each experiment performed at least three times to confirm the consistency of experimental data.

Gentamicin uptake by zebrafish. Zebrafish wild-type and mariner zebrafish larvae, 5 days after fertilization, were treated with conjugates or free fluorophores; $(1 \mu \mathrm{g} / \mathrm{ml}$ in standard E3 medium for 10 min prior to fixation in $4 \%$ formaldehyde for $1 \mathrm{~h}$ and $0.5 \%$ Triton X-100 for 30 min.) Larvae were then labeled with Alexa-488-conjugated phalloidin to confirm hair cell bundles by confocal microscopy.

\subsection{Conclusion}

Genetic inhibition of mechanotransduction reduces gentamicin-fluorophore conjugate uptake. Also, structural modifications of the fluorophore reduce or block gentamicin uptake in kidney and hair cells. The conjugates via their fixed diameters, when used as to measure the maximum dilated MET channel pore size, show that this 
might be between $1.44 \mathrm{~nm}$ to $1.56 \mathrm{~nm}$. However, this needs further validation, for instance, with a larger diameter fluorophore conjugate (2.5), which is currently in progress.

\subsection{Future}

- Synthesis of fluorophore-gentamicin conjugate $\mathbf{2 . 5}$

- Use conjugate $\mathbf{2 . 5}$ to verify the dilated ion channel pore size and test if the structure of this fluorophore is effective in blocking cellular uptake.

- Isolate the gentamicin isomer mixture

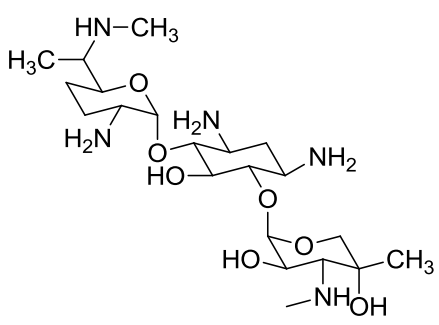

Gentamicin $\mathrm{C}_{1}$

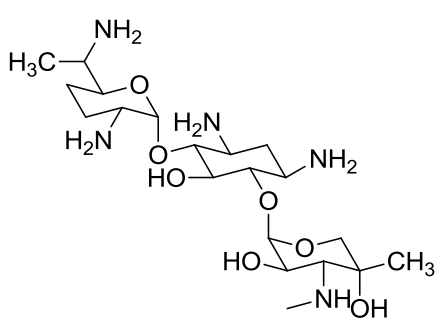

Gentamicin $\mathrm{C}_{2}$

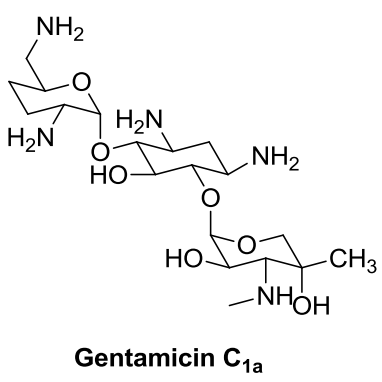

Gentamicin $\mathrm{C}_{1 \mathrm{a}}$ 


\section{CHAPTER 4 SYNTHESIS OF A CISPLATIN-TEXAS RED CONJUGATE}

\subsection{Introduction}

Cisplatin is one of the most powerful anticancer drugs used to treat a wide range of cancers. However, its unwanted side-effects such as ototoxicity and nephrotoxicity remain problematic at the dose required for clinical efficacy. There have been several studies to identify the biodistribution of cisplatin in cells and tissues using positron emission tomography, radiolabeled cisplatin and high-performance liquid chromatography (HPLC). ${ }^{76-79}$ Morphologically, these techniques have low anatomic resolution, and cannot provide the cellular distribution of cisplatin in heterogeneous cellular tissues, like the cochlea in the inner ear. In order to investigate the cellular uptake and intracellular distribution of cisplatin, the use of fluorogenic probes offers an alternative method to these techniques. A fluorescein-cisplatin conjugate has been reported to enter cells via endocytosis. ${ }^{80}$ Recently, a rhodamine-cisplatin has been reported to enter sensory hair cell of the zebrafish neuromast via their apical membranes, potentially via the MET channel or calmodulin-dependent endocytosis. ${ }^{35}$ Several fluorophore-cisplatin conjugates, including fluorescein, cyanine, coumarin and dinitrophenyl, have also been studied (Figure 4.1). ${ }^{81}$ Results reveal that the reactivity of the cisplatin conjugate towards a guanine base is determined to a large extent by the charge properties of the fluorophore: cationic $>$ neutral $>$ anionic.

Thus, it is proposed that the conjugation of anionic dyes such as fluorescein diminishes or neutralizes cisplatin's cationic properties and thus change its bioactivity, as observed for fluorescein-conjugated aminoglycosides. ${ }^{36}$ In order to preserve the drug 
cationic properties, it was envisioned that tagging cisplatin with a rhodamine type fluorophore would overcome these concerns, similar to that for Texas Red-tagged gentamicin. $^{42,82}$

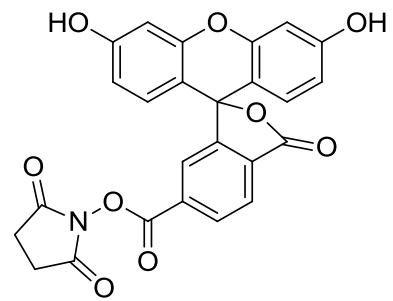

fluorescein-SE

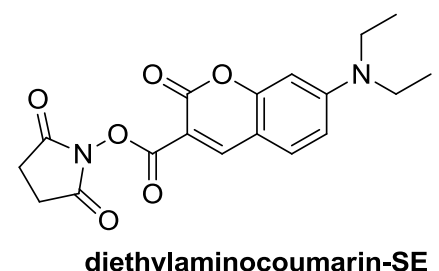<smiles>O=C(CCCCCNc1ccc([N+](=O)[O-])cc1[N+](=O)[O-])ON1C(=O)CCC1=O</smiles>

2,4-dinitrophenyI-SE

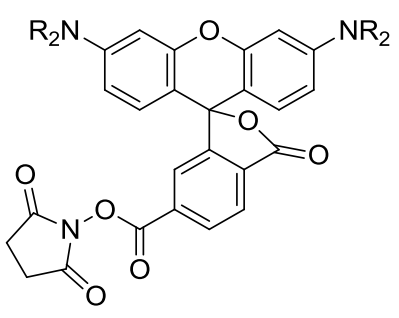

$\mathrm{R}=\mathrm{H}$ carboxyrhodamine-SE $\mathrm{R}=\mathrm{Me}$ rhodamine-SE

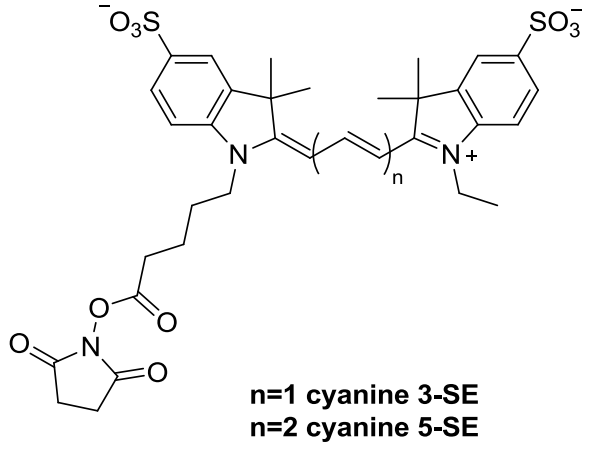

Figure 4.1 Fluorophores have been conjugated with cisplatin and its structure

Therefore, a method was described here to conjugate a cationic commerciallyavailable fluorophore, TR-SE 2.2 to cisplatin (4.1, Figure 4.1) and following systemic injection, will allow to determine localization of cisplatin uptake mechanism within cochlear. A fluorescein-cisplatin conjugate (4.2) was also synthesized and used as a control to study the fluorophore property influence on cellular uptake. A better understanding of the biodistribution of cisplatin, and uptake mechanisms, will facilitate 
the design of new platinum-based pharmacotherapies to diminish or ameliorate the devastating side effects of cisplatin therapy.

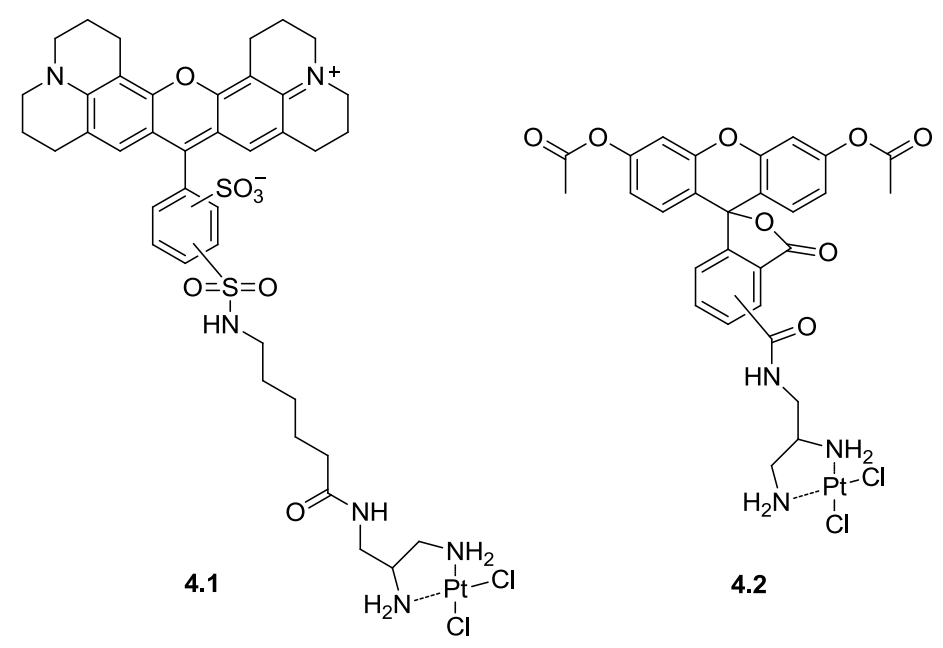

Figure 4.2 Isomers of Cisplatin-Texas Red conjugate, 4.1 and fluorescein conjugate, 4.2

\subsection{Synthetic strategies of cisplatin conjugates}

\subsubsection{Synthesis of cisplatin-fluorescein conjugate, 4.2}

Platinum complex 4.5 was considered appropriate as a cisplatin analogue as it contains a short linker for conjugation and has biological properties similar to cisplatin. Complex 4.3 is synthesized in three steps as described previously by Benoist et al. ${ }^{83}$ The Boc-protected ligand $\mathbf{4 . 3}$ possessing free amino groups can, upon chelation with $\mathrm{Pt}(\mathrm{II})$, afford complex $\mathbf{4 . 4}$ in $75 \%$ yield. The deprotected platinum complex $\mathbf{4 . 5}$ is obtained quantitatively by acid hydrolysis of 4.4. ${ }^{84}$ The overall yield for the platinum complex 4.5 is $53 \%$. 


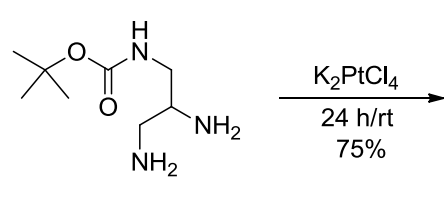

4.3

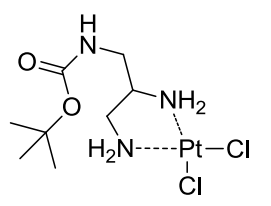

4.4

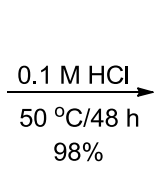

$\sum_{\substack{\mathrm{Cl} \\ \mathrm{H}_{2} \mathrm{~N}-\mathrm{P}_{2} \mathrm{~N}-\mathrm{Cl} \\ \mathrm{NH}_{2}}}^{\mathrm{HCl}}$

4.5

Scheme 4.1 Synthesis of platinum complex 4.5

The synthesis of control fluorescein-cisplatin conjugate (DDP-Fl) was carried out as shown in scheme 4.2. using a known protocol reported by Molenaar et al. ${ }^{84}$ Commercially available fluorophore, 5(6)-carboxyfluorescein diacetate $\mathrm{N}$-succinimidyl ester (4.6, CFDA-SE), is conjugated to deprotected platinum complex 4.5 in anhydrous DMF to afford $\mathbf{4 . 2}$ in $23 \%$ yield.
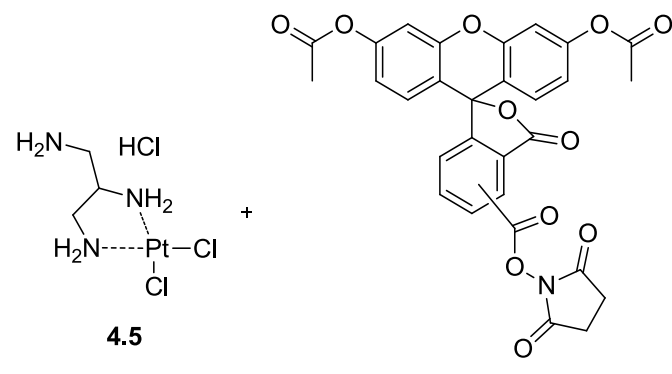

4.6 (mixture of isomers)

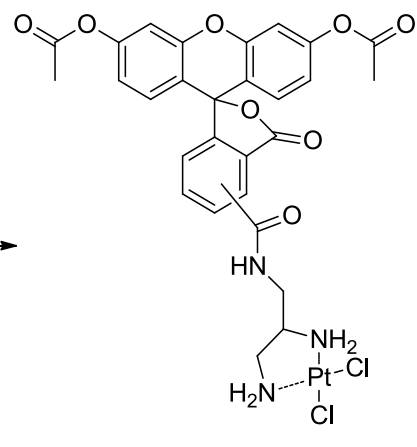

4.2 (mixture of isomers)

Scheme 4.2 Synthesis of DDP-Fl, 4.2

The reversed-phase HPLC analysis of both CFDA-SE 4.6 and the conjugate 4.2 showed only one major peak, without separation. The purity of the conjugate was calculated as $92 \%$. (Figure 4.3 and 4.4 ) 


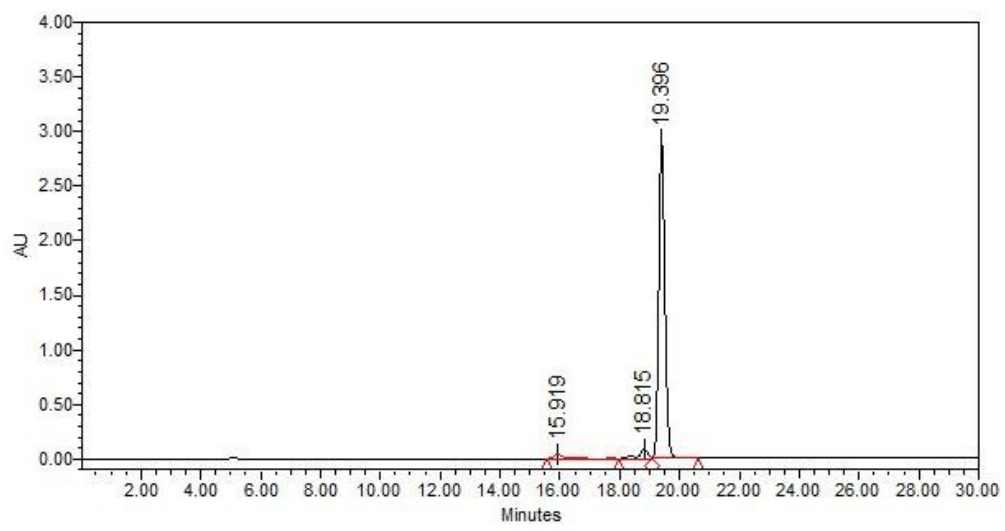

Figure 4.3 HPLC trace of compound 4.6 (isomer mixture).

The injected volume: $5 \mu \mathrm{L}$. Flow rate $0.2 \mathrm{~mL} / \mathrm{min}$; using a $\mathrm{H}_{2} \mathrm{O}: \mathrm{MeCN}$ gradient 70:30 to 95:5 in $25 \mathrm{~min}$; wavelength detection $235 \mathrm{~nm}$.

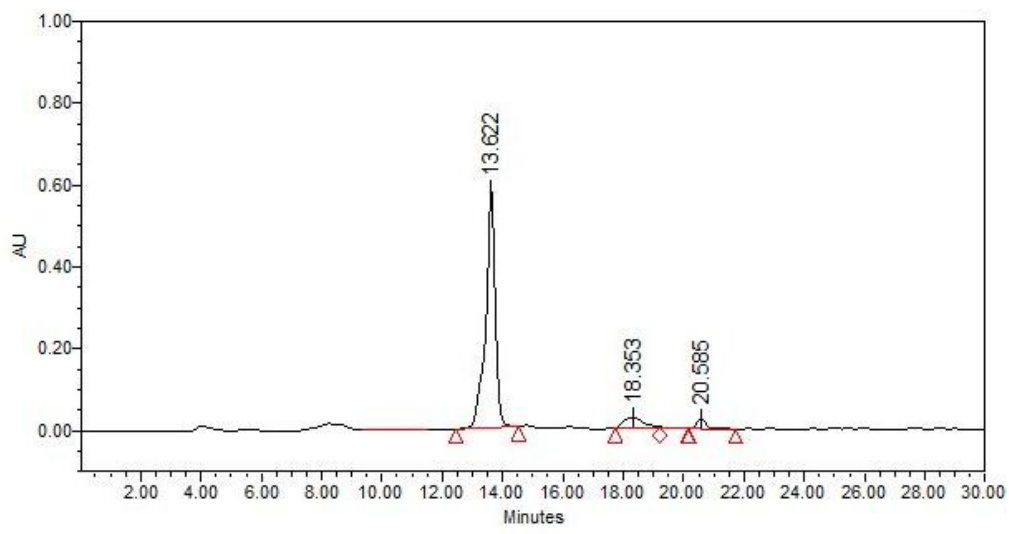

Figure 4.4 HPLC trace of compound 4.2(isomer mixture).

The injected volume: $5 \mu \mathrm{L}$. Flow rate $0.2 \mathrm{~mL} / \mathrm{min}$; using a $\mathrm{H}_{2} \mathrm{O}: \mathrm{MeCN}$ gradient 70:30 to 95:5 in $25 \mathrm{~min}$; wavelength detection $235 \mathrm{~nm}$.

\subsubsection{Synthesis of cisplatin-Texas Red conjugste, 4.1}

The target DDP-TR 4.1 was synthesized as shown in scheme 4.3 in $48 \%$ overall yield. Conjugation was performed by reacting commercially available fluorophore, TRSE 1.1, with deprotected platinum complex 4.5 under basic conditions in $88 \%$ yield. 
DDP-TR 4.1 is characterized by ${ }^{1} \mathrm{H}$ NMR, ${ }^{13} \mathrm{C}$ NMR, ${ }^{195} \mathrm{Pt}$ NMR and LC/MS. The ${ }^{195} \mathrm{Pt}$ NMR spectrum of conjugate 4.1 exhibits a chemical shift at $-2265.40 \mathrm{ppm}$ while the resonance of its parent Pt complex 4.5 is at -2367.05 ppm.
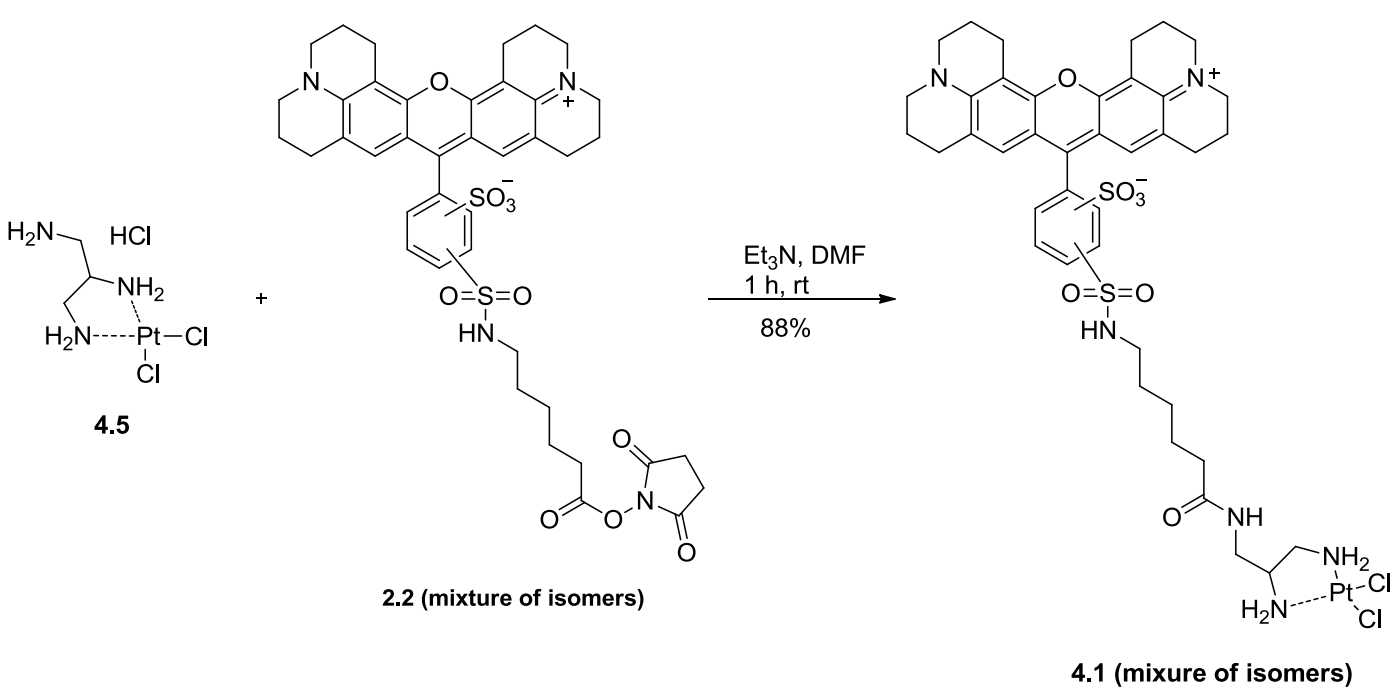

Scheme 4.3 Synthesis of DDP-TR, 4.1

Reversed-phase HPLC analysis shows that the commercial TR-SE 2.2 is actually a mixture containing two isomers (2.2a and $\mathbf{2 . 2 b}$, Figure 4.5) in a 2:1 ratio (Figure 4.6). After conjugation of $\mathbf{2 . 2}$ to platinum complex $\mathbf{4 . 5}$, as expected a more hydrophilic molecule was obtained and the isomer ratio was unchanged (Figure 4.7). The purity of conjugate 4.1 (also a 2:1 mixture of isomers) was calculated as $97 \%$ by reversed phase HPLC. Table 4.1 shows the retention time and composition of both isomeric mixtures. In addition, the HR ESI positive mode MS spectrum was used to confirm the identity of conjugate 4.1, showing the typical isotope pattern of $\mathrm{Pt}$ for the parent ion. 


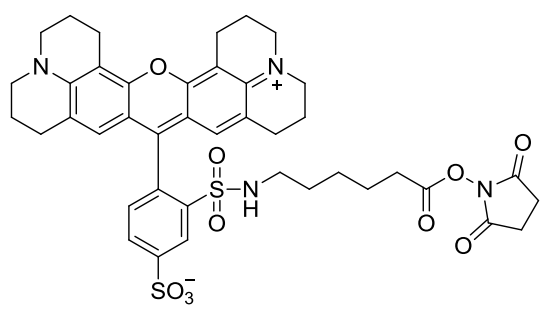

$2.2 a$

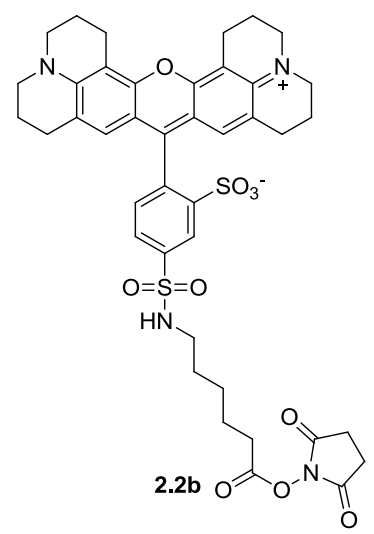

Figure 4.5 Texas Red succinimidyl ester isomers

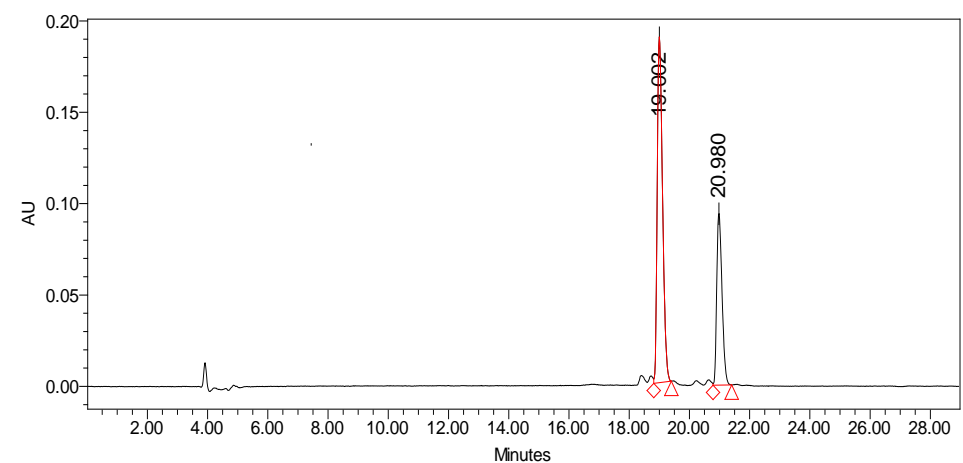

Figure 4.6 HPLC trace of compound 2.2 (isomer mixture).

The injected volume is $5 \mu \mathrm{L}$. Flow rate $0.2 \mathrm{~mL} / \mathrm{min}$; using a $\mathrm{H}_{2} \mathrm{O}: \mathrm{MeCN}$ gradient 95:5 to 5:95 in $25 \mathrm{~min}$; wavelength detection: $590 \mathrm{~nm}$.

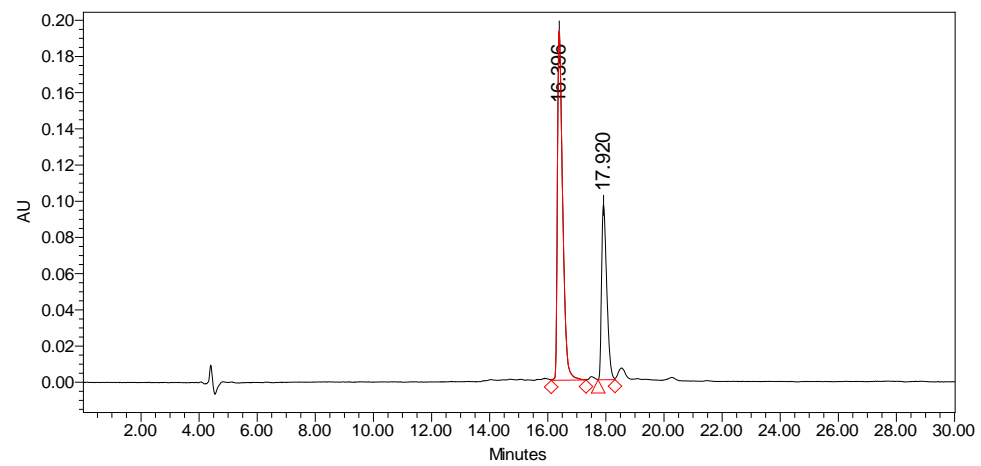

Figure 4.7 HPLC trace of compound 4.1 (isomer mixture).

The injected volume is $5 \mu \mathrm{L}$. Flow rate $0.2 \mathrm{~mL} / \mathrm{min}$; using a $\mathrm{H}_{2} \mathrm{O}: \mathrm{MeCN}$ gradient 95:5 to 5:95 in $25 \mathrm{~min}$; wavelength detection: $590 \mathrm{~nm}$. 
Table 4.1 Retention times and peak areas for each isomer.

\begin{tabular}{|c|c|c|c|c|}
\hline & \multicolumn{2}{|c|}{ Retention Time } & \multicolumn{2}{c|}{ Composition \% } \\
\hline & $\begin{array}{c}\text { Compound } \\
\mathbf{4 . 1}\end{array}$ & $\begin{array}{c}\text { Compound } \\
\mathbf{2 . 2}\end{array}$ & $\begin{array}{c}\text { Compound } \\
\mathbf{4 . 1}\end{array}$ & $\begin{array}{c}\text { Compound } \\
\mathbf{2 . 2}\end{array}$ \\
\hline Peak 1 & 16.39 & 19.00 & 66.88 & 66.85 \\
\hline Peak 2 & 17.92 & 20.98 & 33.12 & 33.15 \\
\hline
\end{tabular}

\subsection{Spectral properties}

\section{Spectroscopic characterization of the cisplatin-Texas Red conjugate 4.1}

In order to determine the newly conjugate $\mathbf{4 . 1}$ has the similar spectral properties as the parent probe TR-SE (2.2), the absorbance and fluorescence spectra of $1.25 \mu \mathrm{M}$ solution of 4.1 and 2.2 were evaluated in $\mathrm{MeOH}$.

Compound 4.1 revealed that the conjugate has similar maximum absorbance intensity as compared to the parent fluorophore, 2.2 (Figure 4.8). As shown in Figure 4.9, the fluorescence excitation maximum was slightly red-shifted by $5 \mathrm{~nm}$ in compound 4.1, otherwise negligible changes in emission spectra were observed compared to $\mathbf{2 . 2}$. Therefore, conjugation to cisplatin preserves the spectral properties of TR-SE, 2.2. 


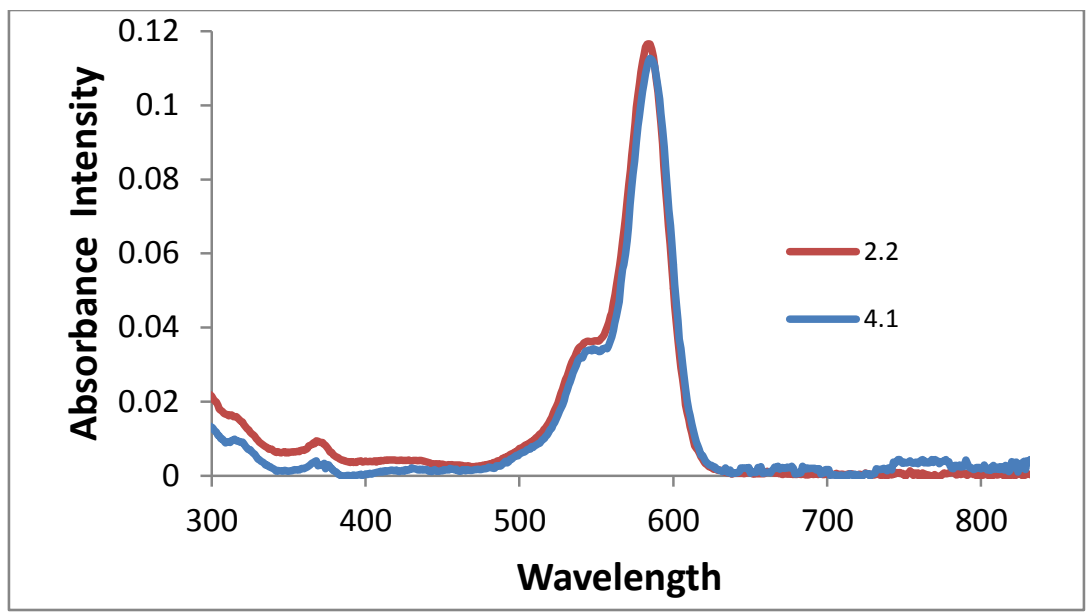

Figure 4.8 Absorption spectra of $1.25 \mu \mathrm{M}$ of $\mathbf{4 . 1}$ and 2.2 in $\mathrm{MeOH}$.

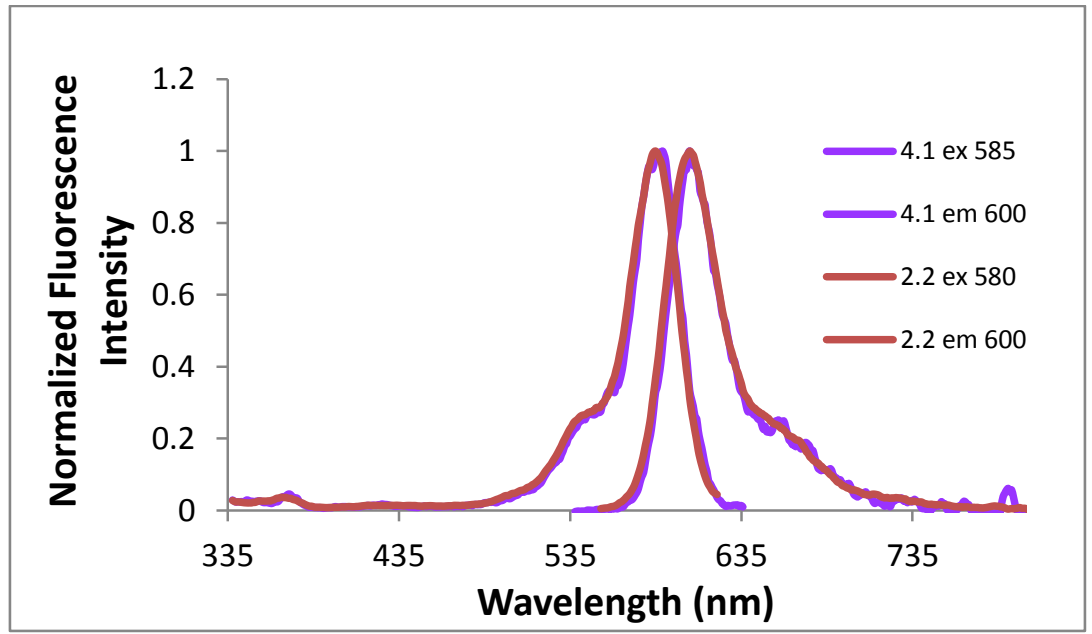

Figure 4.9 Excitation/Emission fluorescence spectra of $1.25 \mu \mathrm{M}$ of $\mathbf{4 . 1}$ and 2.2 in $\mathrm{MeOH}$.

\subsection{Cellular studies}

In order to test the hypothesis that anionic fluorescein will diminish cisplatin's cationic properties and change its bioactivity, both DDP-Fl (4.2) and DDP-TR (4.1) were used in MDCK (Madin-Darby Canine Kidney) cells for this study. In addition, zebrafish neuromast hair cells were used to verify the cytotoxicity. 


\section{Cellular uptake by MDCK cells with DDP-Fl (4.2) and DDP-TR (4.1)}

Cells were incubated with $10 \mu \mathrm{g} / \mathrm{ml}$ of DDP-Fl or DDP-TR for $30 \mathrm{~s}$ at $\mathrm{rt}$ to preclude endocytosis, then fixed with formaldehyde plus Triton X-100 for 40 min and imaged with similar laser power settings. Cellular uptake of DDP-TR had stronger fluorescent intensity than cells treated with DDP-Fl. This suggests that anionic property of fluorescein may potentially change the bioactivity of cisplatin and renders no cellular uptake. (Figure 4.10)
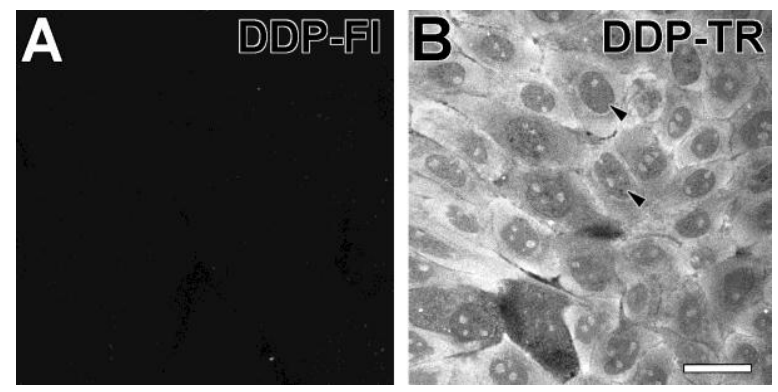

Figure 4.10 Comparison of DDP-Fl (A) and DDP-TR (B) uptake by MDCK cells. MDCK cells were treated with $10 \mu \mathrm{g} / \mathrm{ml}$ of conjugates for $30 \mathrm{~s}$ at $20^{\circ} \mathrm{C}$ to preclude endocytosis, fixed with formaldehyde plus Triton X-100 for $40 \mathrm{~min}$. The scale bar is 10 microns.

\section{DDP-TR toxicity in zebrafish neuromast hair cells}

To verify that DDP-TR retains the cytotoxic properties of cisplatin, the relative toxicity of cisplatin and DDP-TR were compared using zebrafish neuromast hair cells. Larvae were treated with a dose range of cisplatin, DDP-TR, or unconjugated Texas Red for $4 \mathrm{~h}$ and allowed to recover for $3 \mathrm{~h}$.

Alexa-488-conjugated phalloidin labeling of the hair bundle and cuticular plate determined the number of surviving hair cells. Hair cells can cleave their hair bundles 
following drug exposure ${ }^{85}$ yet the loss of the hair bundle or cuticular plate is an ototoxic event. After treatment with DDP-TR (10-200 $\mathrm{mg} / \mathrm{mL})$ for $4 \mathrm{~h}$, plus $3 \mathrm{~h}$ of recovery, the number of surviving hair cells decreased with increasing dose (Figure 4.11A-C, E). Treatment with unconjugated Texas Red revealed no fluorescence in hair cells suggesting that the forced uptake of Texas Red, via conjugation to cisplatin, was responsible for the enhanced toxicity of DDP-TR. (Figure 4.11D) To quantify and normalize this decrease, untreated controls provided a baseline to determine the ratio of surviving hair cells in zebrafish neuromasts. Both cisplatin and DDP-TR decreased hair cell numbers in a dosedependent manner (Figure 4.11E).
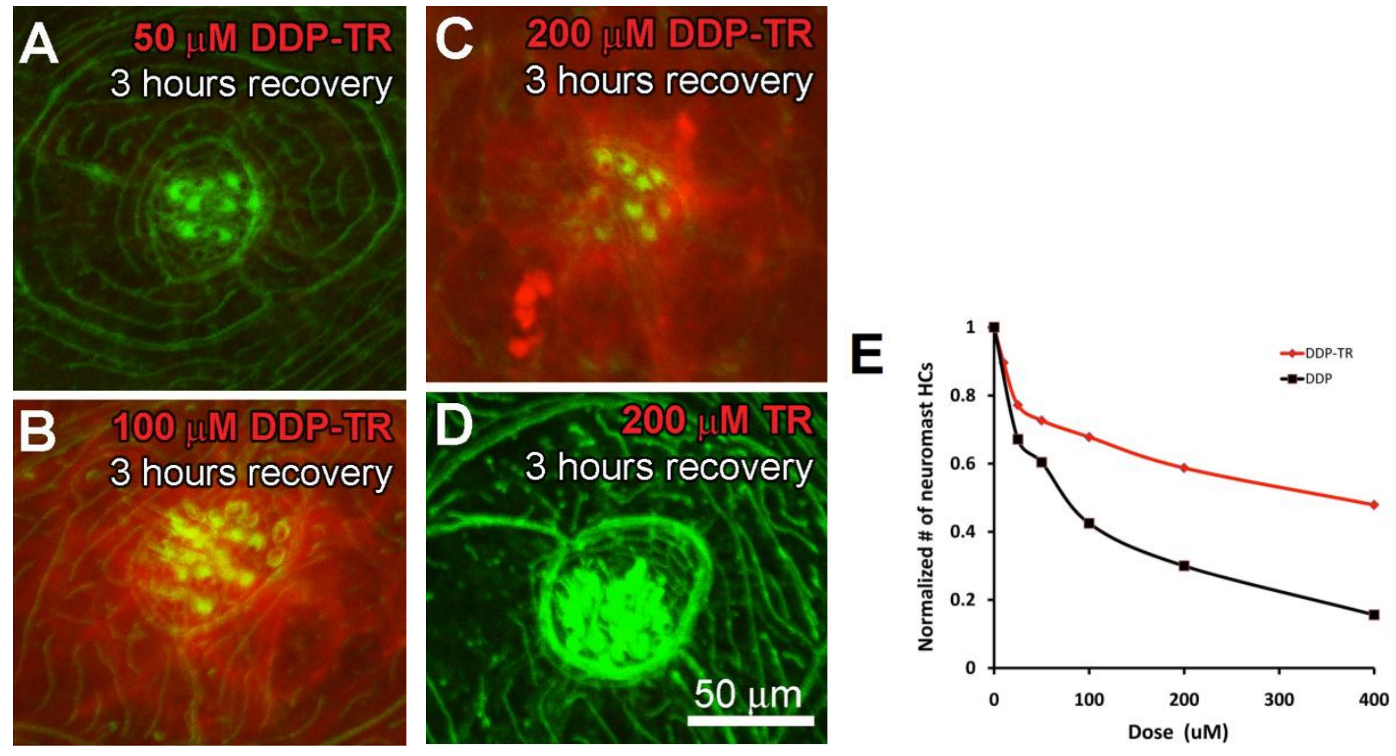

Figure 4.11 Cytoxicity in zebrafish neuromast hair cells with a range of dose.

(A-C) To verify the cytotoxicity of DDP-TR, 4.1 a zebrafish was treated with various concentrations of conjugate $(50-200 \mathrm{mg} / \mathrm{mL}$ ) for $4 \mathrm{~h}$, plus $3 \mathrm{~h}$ of recovery. Upon increasing the dose of conjugate, the number of hair cells decreased. (D) Treatment with unconjugated Texas Red showed no fluorescence within neuromasts. (E) Quantifying the relative surviving hair cells of zebrafish with cisplatin and conjugate treatment: the conjugate appears less toxic than cisplatin. 


\subsection{Experimental section}

\section{Material and Methods}

General. All chemicals were used as received without further purification. ${ }^{1} \mathrm{H}-$ NMR, ${ }^{13} \mathrm{C}-\mathrm{NMR}$ and ${ }^{195} \mathrm{Pt}-\mathrm{NMR}$ were acquired on an ARX-400 Avance Bruker spectrometer. Chemical shifts $(\delta)$ are given in ppm relative to TMS. For ${ }^{195} \mathrm{Pt}-\mathrm{NMR}$, $\mathrm{K}_{2} \mathrm{PtCl}_{4}$ was used as external standard. Mass spectra was conducted at PSU Bioanalytical Mass Spectrometry Facility on a ThermoElectron LTQ-Orbitrap Discovery high resolution mass spectrometer coupled to an Accela HPLC system. The reversed phase HPLC consists of a 1525 binary delivery system, and a 2996 Photodiode array detector

(Waters). A Supelco ${ }^{\mathrm{TM}} \mathrm{C}-18(25 \mathrm{~cm} \times 2.1 \mathrm{~mm}, 5 \mu \mathrm{m})$ column was used for the separation. Fluorescence measurements were carried out on a Cary Eclipse ${ }^{\mathrm{TM}}$ fluorescence spectrophotometer (Agilent Technologies), and absorption measurements were performed on a Cary Eclipse ${ }^{\mathrm{TM}} 50$ Bio UV-Vis spectrophotometer.

Synthesis of $N_{3}$-(tert-Butoxycarbonyl)-1,2,3-propanetriamine, 4.3. Compound 4.3 was synthesized from 3-amino-1,2-propanediol in three steps as reported by Benoist et al. with an overall yield of $73 \%$. NMR spectroscopic and MS data are in agreement with the literature. ${ }^{83}$

Synthesis of $N$-(tert-Butoxycarbonyl)-1-aminomethyl-1,2 ethylenediamine) dichloroplatinum(II), 4.4. Compound 4.4 was synthesized using a modified procedure reported previously by Molenaar et al. Under Ar system, $\mathrm{K}_{2} \mathrm{PtCl}_{4}(1.1 \mathrm{~g}, 2.64 \mathrm{mmol})$ was dissolved in $50 \mathrm{~mL}$ of DI water. The Boc-protected diamine 4.3 (0.5 g, $2.64 \mathrm{mmol})$ was dissolved in $10 \mathrm{~mL}$ of DI water and added to the $\mathrm{K}_{2} \mathrm{PtCl}_{4}$ solution. The reaction mixture 
was stirred at rt for $24 \mathrm{~h}$, and a pale yellow solid was formed. The solid was filtered, washed with $\mathrm{H}_{2} \mathrm{O}(5 \times 50 \mathrm{~mL})$, and dried under vacuum (yield: $\left.0.9 \mathrm{~g}, 75 \%\right)$. NMR spectroscopic and MS data are in agreement with the literature. ${ }^{84}$

Synthesis of (1-aminomethyl-1,2-ethylenediamine)dichloroplatinum(II) hydrochloride, 4.5. Compound $4.4(0.518 \mathrm{~g}, 1.137 \mathrm{mmol})$ was suspended in $50 \mathrm{~mL}$ of $0.1 \mathrm{M} \mathrm{HCl}$, followed by the addition of $2.5 \mathrm{~mL}$ of $1.0 \mathrm{M} \mathrm{HCl}$. The reaction mixture was heated at $50{ }^{\circ} \mathrm{C}$ for $24 \mathrm{~h}$. More $1 \mathrm{M} \mathrm{HCl}(0.5 \mathrm{~mL})$ was added and the reaction mixture was kept at $50{ }^{\circ} \mathrm{C}$ for another $24 \mathrm{~h}$. The reaction was cooled down to $\mathrm{rt}$ and the aqueous solution was filtered through a $22 \mu \mathrm{m}$ syringe filter to remove white precipitates. The filtrate was evaporated under vacuum to afford a yellow solid (441 mg, 99\%). NMR spectroscopic and MS data are in agreement with the literature. ${ }^{84}$

Synthesis of DDP-Fl, 4.2. Compound 4.2 was synthesized using a procedure reported by Molenaar et al in $23 \%$ yield. NMR spectroscopic and MS data are in agreement with published values. ${ }^{84}$

Synthesis of DDP-TR, 4.1. Platinum complex 4.5 (10.55 mg, $26.93 \mu \mathrm{mol})$ was dissolved in $1.2 \mathrm{~mL}$ of anhydrous DMF and sonicated for $10 \mathrm{~min}^{-\mathrm{Et}_{3} \mathrm{~N}}(10.24 \mu \mathrm{L}, 73.44$ $\mu \mathrm{mol})$ was added in one portion and the mixture was sonicated for another $5 \mathrm{~min}$, resulting in a clear pale yellow solution; if necessary, DI water was added in increments of $20 \mu \mathrm{L}$ and sonicated until completely dissolved. TR-SE $2.2(20 \mathrm{mg}, 24.48 \mu \mathrm{mol}$; Invitrogen $\mathrm{CA}$ ) was added, and the reaction mixture stirred at $\mathrm{rt}$ for $1 \mathrm{~h}$, prior to evaporation under vacuum to afford a purple precipitate. The residue was centrifuged and washed with cold $\mathrm{H}_{2} \mathrm{O}(2 \times 10 \mathrm{~mL})$ and $\mathrm{Et}_{2} \mathrm{O}(3 \times 10 \mathrm{~mL})$ until the supernatant became 
almost clear, and dried under vacuum to afford a purple solid (yield: $88 \%, 22.8 \mathrm{mg}$ ). HRMS (ESI): $\mathrm{m} / \mathrm{z}\left[\mathrm{M}+\mathrm{H}^{+}\right]$calculated for $\mathrm{C}_{41} \mathrm{H}_{51} \mathrm{Cl}_{2} \mathrm{~N}_{6} \mathrm{O}_{7} \mathrm{PtS}_{2}$ : 1056.2282; observed 1056.2354. Moreover, the HPLC-MS analysis confirms that the first peak from the conjugate isomers of $\mathbf{4 . 1}$ appears at 17.67 min with $\mathrm{m} / \mathrm{z}$ of 1056.2322 for $[\mathrm{M}+\mathrm{H}]^{+}$, and the second peak appears at $19.15 \mathrm{~min}$ with $\mathrm{m} / \mathrm{z}$ of 1056.2260 for $[\mathrm{M}+\mathrm{H}]^{+}$.

\section{HPLC Analysis}

HPLC analysis of Compounds 4.1 and 2.2. The injected volume of 4.1 and 2.2 was $5 \mu \mathrm{L}$. The mobile phase consisted of $\mathrm{H}_{2} \mathrm{O}: \mathrm{MeCN}$ with a gradient elution from 95:5 to 5:95 in $25 \mathrm{~min}$, with a flow rate of $0.2 \mathrm{~mL} / \mathrm{min}$. The UV/Vis scan range was $200-700 \mathrm{~nm}$. The detection wavelength was set at $590 \mathrm{~nm}$.

HPLC analysis of Compounds 4.2 and 4.6. The injected volume of 4.2 and 4.6 was $5 \mu \mathrm{L}$. The mobile phase consisted of $\mathrm{H}_{2} \mathrm{O}: \mathrm{MeCN}$ with a gradient elution from 70:30 to $95: 5$ in $25 \mathrm{~min}$, with a flow rate of $0.2 \mathrm{~mL} / \mathrm{min}$. The detection wavelength was set at $235 \mathrm{~nm}$.

\section{Fluorescence Spectroscopic Evaluation}

Fluorescence Spectra of Compounds 4.1 and 2.2. Stock solutions of 4.1 and 2.2 were prepared in $\mathrm{MeOH}$. Fluorescence spectra were recorded at excitation/emission wavelengths of $585 \mathrm{~nm} / 600 \mathrm{~nm}$ (compound 4.1) and $580 \mathrm{~nm} / 600 \mathrm{~nm}$ (compound 2.2) with the bandwidths set at $5 \mathrm{~nm}$.

\section{Cellular studies}

MDCK cells. MDCK cells were cultured in antibiotic and phenol red-free Dulbecco's minimal essential medium (MEM, Invitrogen, Ca) with $10 \%$ fetal bovine 
serum at $37^{\circ} \mathrm{C}$ with $5 \% \mathrm{CO}_{2}, 95 \%$ air. Cells were seeded into 8-well coverglass chambers (ISC BioExpress) at 3000 cells/well and grown for 5 days, when they had become subconfluent, cuboidal, and had time to develop tight junctions. Cells were washed three times with PBS (with $1.25 \mathrm{mM}$ calcium) and treated with $10 \mu \mathrm{g} / \mathrm{ml}$ of DDP-Fl or DDPTR for $30 \mathrm{~s}$ at $20^{\circ} \mathrm{C}$ to preclude endocytosis, fixed with formaldehyde plus Triton $\mathrm{X}-100$ for $40 \mathrm{~min}$ and then imaged with approximately similar laser power settings.

Zebrafish. Wildtype zebrafish larvae, 5 days after fertilization, were treated with a dose range of DDP-TR or cisplatin (10 to $400 \mathrm{mg} / \mathrm{ml}$ in standard E3 medium) for $4 \mathrm{~h}$ and recovered for $3 \mathrm{~h}$ prior to fixation in $4 \%$ formaldehyde containing $0.5 \%$ Triton X-100. Larvae were then labeled Alexa-488-conjugated phalloidin to determine the number of surviving hair cell bundles.

\subsection{Conclusion}

Platinum complex $\mathbf{4 . 5}$ with a short linker for conjugation was synthesized in 5 steps with $53 \%$ yield. DDP-TR, 4.1 was successfully synthesized using platinum complex 4.5 conjugated with commercially available TR-SE (2.2) with an unchanged isomer ratio in $97 \%$ purity. Spectroscopic evaluation showed that the conjugation of cisplatin preserved the spectral properties of Texas Red, 2.2.

Cellular studies showed that the anionic properties of fluorescin neutralize positive charge of cisplatin and change its bioactivity: there is no cellular uptake of DDPFl by MDCK cell as comparison with DDP-TR, 4.1. Cisplatin is a relatively small molecule, so conjugation could alter the kinetics of uptake as well as cytotoxicity. In 
vitro studies showed that the new DDP-TR has similar but reduced cytotoxicity to hair cells as compared to unconjugated cisplatin, and in a dose-dependent manner.

\subsection{Future Work}

- Conjugation of cisplatin to the series of rhodamine analogs to serve the same purpose as gentamicin conjugates in determining ion channel and transporter properties.
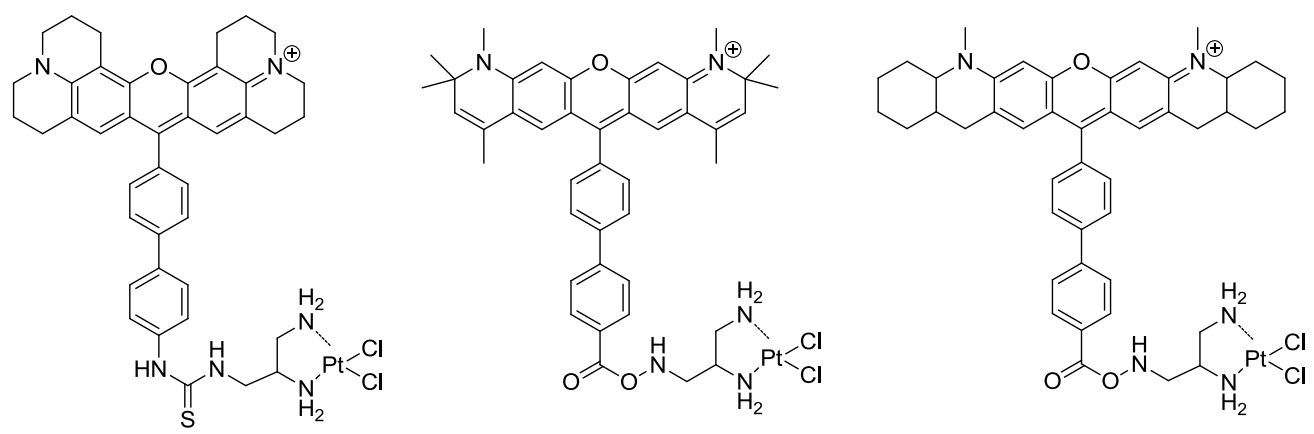


\section{CHAPTER 5 SYNTHESIS OF A TETRAAMINO PLATINUM-TEXAS RED CONJUGATE}

\subsection{Introduction}

Carboplatin (Figure 5.1) is an analog of cisplatin and is widely used but for fewer types of cancers compared to cisplatin. These include ovarian, lung, and head and neck

cancers. ${ }^{25}$ Carboplatin is less toxic as compared to cisplatin due to replacing cisplatin's chloride leaving groups with a cyclobutane-1,1-dicarboxylato ligand. ${ }^{86}$ This increases stability and inhibits exchange with aqua ligands leading to the more bioactive form that induces cytotoxicity in the cochlea and kidney. ${ }^{87}$ Even though carboplatin is less ototoxic and nephrotoxic compared to cisplatin, the cytotoxicity and these unwanted side-effects still occurs and remains an issue for clinical efficacy. ${ }^{88}$

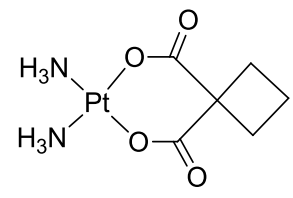

Figure 5.1 Carboplatin

A common structural feature shared by cisplatin and carboplatin is the diamine groups. These drugs can induce cytotoxicity through molecular interactions via their amino groups. It is hypothesized that proteins specifically bind to cisplatin and carboplatin at the two amines, and that the protein-drug interactions could induce cell death associated with toxicity to the cochlea and kidney. The analogous amine platinum complex (5.1, Figure 5.2) has been previously synthesized and used to identify cisplatinbinding proteins relevant to cytotoxicity, but not specific to the cochlea and kidney. ${ }^{89}$ 
Therefore, in order to identify the biodistribution of platinum binding proteins in vivo in heterogeneous cellular composition in kidney and cochlea, it is proposed to synthesize the tetra-amino platinum Texas Red conjugate as shown in Scheme 5.1.

\subsection{Synthesis of a tetra-amino platinum complex and its Texas Red Conjugate}

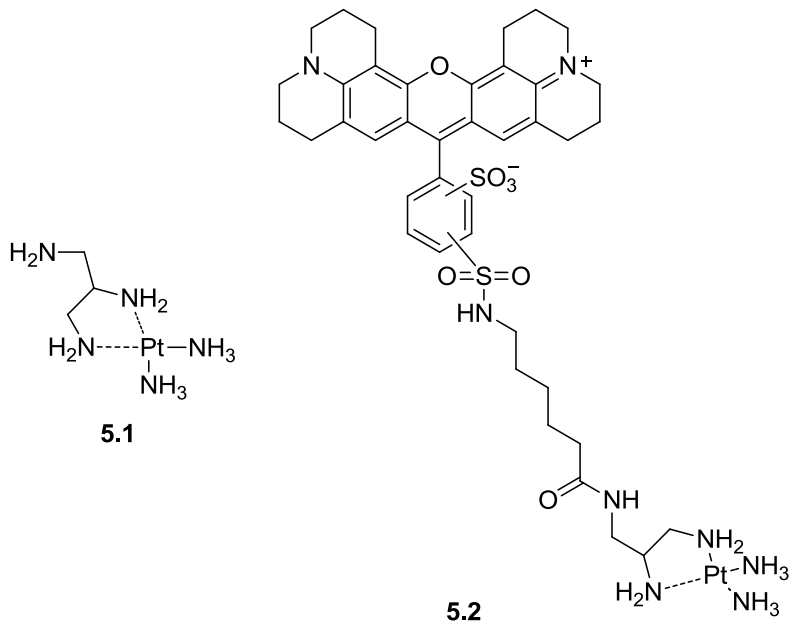

Figure 5.2 Amino platinum complex 5.1 and its proposed Texas Red conjugate 5.2

Platinum complex $\mathbf{5 . 1}$ was chosen as an analog of cisplatin and carboplatin because it contains a free amine terminated short linker to allow conjugation to the fluorophore. It is expected that the two free amine groups will bind to proteins, which will allow one to determine if this structural feature is responsible for the lower cytotoxicity observed for carboplatin.

The corresponding platinum complex, 4.5 and platinum complex 5.1, bearing a free amino group for further conjugation to other biomolecules, were synthesized as shown in scheme 5.1. Complex 5.1, was synthesized in $52 \%$ overall yield following a 
modified procedure by Hall et al. ${ }^{90}$ The Pt complex $\mathbf{5 . 1}$ was obtained in $98 \%$ yield from 4.5, via the formation of the di-aquo complex 5.3, followed by ligand exchange with excess of $\mathrm{NH}_{4} \mathrm{OH}$. All synthesized platinum complexes were characterized by ${ }^{1} \mathrm{H} \mathrm{NMR}$, ${ }^{13} \mathrm{C}$ NMR, ${ }^{195} \mathrm{Pt}$ NMR and ESI/MS. The synthesis of conjugate $\mathbf{5 . 2}$ is currently underway, which will be performed by conjugation of $\mathbf{5 . 1}$ to TR-SE 2.2 under basic condition in anhydrous DMF or by ligand exchange following the same procedure as the one used to obtain compound 5.1.

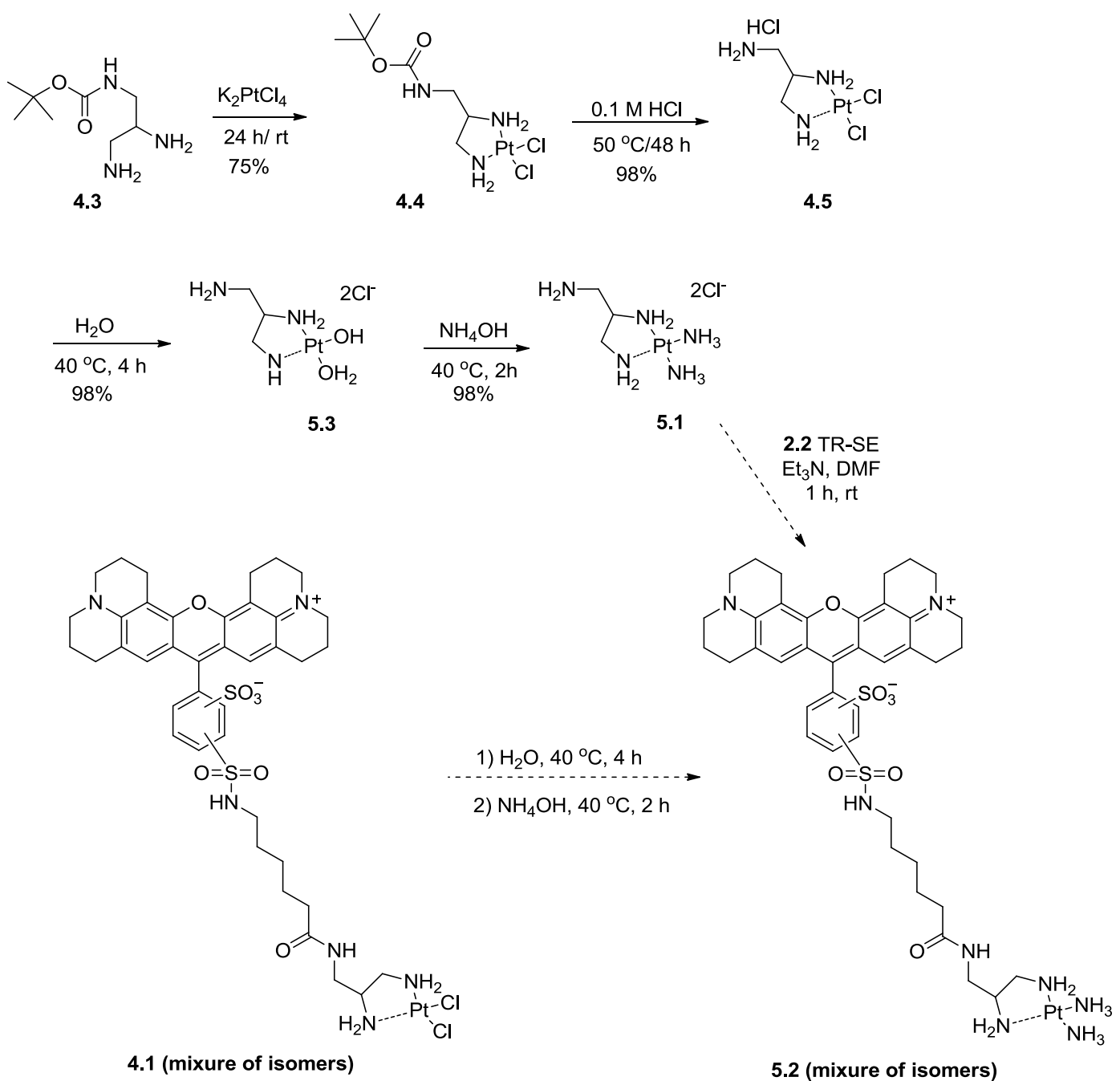

Scheme 5.1 Proposed synthetic scheme of $\mathbf{5 . 2}$ 


\subsection{Conclusion and future work}

The tetra-amino platinum complex $\mathbf{5 . 1}$ has been synthesized and used to identify cispaltin-binding proteins. Effort is underway to synthesize a fluorescent tetra-amino platinum conjugate, 5.2. It will be used to study the biodistribution in vivo of the tetraamino platinum complex and cellular uptake as compared to the control conjugate of DDPTR 4.1. 


\section{References}

1. Sanders, W. E.; Pejovic, I.; Cacciatore, R.; Valdez, H.; Dunbar, F. P. J. Infec. Dis. 1971, 124, S33.

2. Cottagnoud, P.; Gerber, C. M.; Cottagnoud, M.; Tauber, M. G. Antimicrob. Agents Chemother. 2002, 46, 188.

3. Clancy, J. P.; Bebok, Z.; Ruiz, F.; King, C.; Jones, J.; Walker, L.; Greer, H.; Hong, J.; Wing, L.; Macaluso, M.; Lyrene, R.; Sorscher, E. J.; Bedwell, D. M. Am. J. Respir. Crit. Care. Med. 2001, 163, 1683.

4. Zaske, D. E.; Bootman, J. L.; Solem, L. B.; Strate, R. G. Surgery 1982, 91, 142.

5. $\quad$ Pillers, D. M.; Schleiss, M. R. The Volta Review 2005, 105, 205.

6. Kahlmeter, G.; Dahlager, J. I. J. Antimicrob. Chemother. 1984, 13, 9.

7. Mohr, P. E.; Feldman, J. J.; Dunbar, J. L.; McConkey-Robbins, A.; Niparko, J. K.; Rittenhouse, R. K.; Skinner, M. W. Int. J. Technol. Assess. Health Care 2000, 16, 1120 .

8. $\quad$ Begg, E. J.; Barclay, M. L. Br. J. Clin. Pharmacol. 1995, 39, 597.

9. Kohanski, M. A.; Dwyer, D. J.; Collins, J. J. Nat. Rev. Microbiol. 2010, 8, 423.

10. Hashino, E.; Shero, M.; Salvi, R. J. Brain Res. 2000, 887, 90.

11. Sandoval, R.; Leiser, J.; Molitoris, B. A. J. Am. Soc. Nephrol. 1998, 9, 167.

12. Decorti, G.; Malusa, N.; Furlan, G.; Candussio, L.; Klugmann, B. F. Life Sci. Res. Rep. 1999, 65, 1115.

13. Marcotti, W.; van Netten, S. M.; Kros, C. J. J. Physiol. 2005, 567, 505.

14. Hashino, E.; Shero, M. Brain Res. 1995, 704, 135.

15. Wang, Q.; Kachelmeier, A.; Steyger, P. S. Hear. Res. 2010, 268, 250.

16. Rosenberg, B.; Van Camp, L.; Krigas, T. Nature 1965, 205, 698.

17. Roberts, D.; O’Dwyer, P.; Johnson, S. In Cancer Management in Man: Chemotherapy, Biological Therapy, Hyperthermia and Supporting Measures; Minev, B. R., Ed.; Springer Netherlands: 2011; Vol. 13, p 145.

18. Wong, E.; Giandomenico, C. M. Chem. Rev. 1999, 99, 2451. 
19. Weiss, R. B.; Christian, M. C. Drugs 1993, 46, 360.

20. Einhorn, L. H. Proc. Natl. Acad. Sci. U. S. A. 2002, 99, 4592.

21. Knight, K. R.; Kraemer, D. F.; Neuwelt, E. A. J. Clin. Oncol. 2005, 23, 8588.

22. Knight, K. R.; Kraemer, D. F.; Winter, C.; Neuwelt, E. A. J. Clin. Oncol. 2007, 25,1190 .

23. Skinner, R.; Pearson, A. D.; English, M. W.; Price, L.; Wyllie, R. A.; Coulthard, M. G.; Craft, A. W. Br. J. Cancer 1998, 77, 1677.

24. Kostova, I. Recent Patents Anticancer Drug Discov. 2006, 1, 1.

25. Wang, D.; Lippard, S. J. Nat. Rev. Drug Discov. 2005, 4, 307.

26. Ozkok, A.; Edelstein, C. L. BioMed Research International 2014, 2014, 17.

27. Siddik, Z. H. Oncogene 2003, 22, 7265.

28. Kruidering, M.; van de Water, B.; de Heer, E.; Mulder, G. J.; nagelkerke, J. F. J. Pharmacol. Exp. Ther. 1997, 280, 638.

29. Baliga, R.; Zhang, Z.; Baliga, M.; Ueda, N.; Shah, S. V. Kidney Int. 1998, 54, 1562.

30. Burger, H.; Loos, W. J.; Eechoute, K.; Verweij, J.; Mathijssen, R. H. J.; Wiemer, E. A. C. Drug Resist. Updat. 2011, 14, 22.

31. Hall, M. D.; Okabe, M.; Shen, D.-W.; Liang, X.-J.; Gottesman, M. M. Annu. Rev. Pharmacol. Toxicol. 2008, 48, 495.

32. Spreckelmeyer, S.; Casini, A.; Orvig, C. Molecules 2014, 19, 15584.

33. Ciarimboli, G.; Deuster, D.; Knief, A.; Sperling, M.; Holtkamp, M.; Edemir, B.; Pavenstaedt, H.; Lanvers-Kaminsky, C.; Zehnhoff-Dinnesen, A. a.; Schinkel, A. H.; Koepsell, H.; Juergens, H.; Schlatter, E. Am. J. Pathol. 2010, 176, 1169.

34. More, S. S.; Akil, O.; Ianculescu, A. G.; Geier, E. G.; Lustig, L. R.; Giacomini, K. M. J. Neurosci. 2010, 30, 9500.

35. Thomas, A. J.; Hailey, D. W.; Stawicki, T. M.; Wu, P.; Coffin, A. B.; Rubel, E. W.; Raible, D. W.; Simon, J. A.; Ou, H. C. J. Neurosci. 2013, 33, 4405.

36. Dulon, D.; Zajic, G.; Aran, J. M.; J., S. J. Neurosci. Res. 1989, 24, 338. 
37. Luedtke, N. W.; Carmichael, P.; Tor, Y. J. Am. Chem. Soc. 2003, 125, 12374.

38. Kirk, S. R.; Luedtke, N. W.; Tor, Y. J. Am. Chem. Soc. 2000, 122, 980.

39. Grote, J.; Himmelsbach, R.; Johnson, D. Tetrahedron Lett. 2012, 53, 6751.

40. Myrdal, S. E.; Johnson, K. C.; Steyger, P. S. Hear. Res. 2005, 204, 156.

41. Myrdal, S. E.; Steyger, P. S. Hear. Res. 2005, 204, 170.

42. Wang, Q.; Steyger, P. S. J. Assoc. Res. Otolaryngol. 2009, 10, 205.

43. Dai, C. F.; Mangiardi, D.; Cotanche, D. A.; Steyger, P. S. Hear. Res. 2006, 213, 64.

44. Steyger, P. S.; Peters, S. L.; Rehling, J.; Hordichok, A.; Dai, C. F. J. Assoc. Res. Otolaryngol. 2003, 4, 565.

45. Schacht, J. Arch. Otorhinolaryngol. 1979, 224, 129.

46. Williams, S. E.; Zenner, H. P.; Schacht, J. Hear. Res. 1987, 30, 11.

47. Zheng, J.; Dai, C.; Steyger, P. S.; Kim, Y.; Vass, Z.; Ren, T.; Nuttall, A. L. J. Neurophysiol. 2003, 90, 444.

48. Karasawa, T.; Wang, Q.; Fu, Y.; Cohen, D. M.; Steyger, P. S. J. Cell Sci. 2008, 121, 2871.

49. Havekes, R.; Nijholt, I. M.; Visser, A. K.; Eisel, U. L.; Van der Zee, E. A. Neurobiol. Learn. Mem. 2008, 89, 595.

50. Farris, H. E.; LeBlanc, C. L.; Goswami, J.; Ricci, A. J. J. Physiol. (Oxford, U. K.) 2004, 558, 769 .

51. Chung, M. K.; Guler, A. D.; Caterina, M. J. Nat. Neurosci. 2008, 11, 555.

52. Jara-Oseguera, A.; Llorente, I.; Rosenbaum, T.; Islas, L. D. J. Gen. Physiol. 2008, 132, 547.

53. Moiseenkova-Bell, V. Y.; Stanciu, L. A.; Serysheva, II; Tobe, B. J.; Wensel, T. G. Proc. Natl. Acad. Sci. U. S. A. 2008, 105, 7451.

54. Shigematsu, H.; Sokabe, T.; Danev, R.; Tominaga, M.; Nagayama, K. J. Biol. Chem. 2010, 285, 11210. 
55. Banke, T. G.; Chaplan, S. R.; Wickenden, A. D. Am. J. Physiol. Cell Physiol. 2010, 298, C1457.

56. Jiao, G. S.; Castro, J. C.; Thoresen, L. H.; Burgess, K. Org. Lett. 2003, 5, 3675.

57. $\quad$ Crich, D.; Sana, K. J. Org. Chem. 2009, 74, 7383.

58. Sibrian-Vazquez, M.; Jensen, T. J.; Fronczek, F. R.; Hammer, R. P.; Vicente, M. G. H. Bioconjug. Chem. 2005, 16, 852.

59. Belov, V. N.; Bossi, M. L.; Folling, J.; Boyarskiy, V. P.; Hell, S. W. Chemistry 2009, 15, 10762.

60. Read, M. W.; Escobedo, J. O.; Willis, D. M.; Beck, P. A.; Strongin, R. M. Org. Lett. 2000, 2, 3201.

61. Ghorai, M. K.; Nanaji, Y.; Yadav, A. K. Org. Lett. 2011, 13, 4256.

62. Bower, F. J. S., P. Gallagher, T. 2007, 5, 143.

63. Hsieh, J.-C.; Cheng, A.-Y.; Fu, J.-H.; Kang, T.-W. Org. Biomol. Chem. 2012, 10, 6404.

64. Shen, Y.; Hou, S.; Yu, Y.; Zhao, L.; Xu, H.; Zhang, Y.; Anyang Institute of Technology, Peop. Rep. China . 2012, p 12pp.

65. Acker, T. M.; Khatri, A.; Vance, K. M.; Slabber, C.; Bacsa, J.; Snyder, J. P.; Traynelis, S. F.; Liotta, D. C. J. Med. Chem. 2013, 56, 6434.

66. Dong, G.; Wang, S.; Miao, Z.; Yao, J.; Zhang, Y.; Guo, Z.; Zhang, W.; Sheng, C. J. Med. Chem. 2012, 55, 7593.

67. Sun, M.; Ma, Y.-N.; Li, Y.-M.; Tian, Q.-P.; Yang, S.-D. Tetrahedron Lett. 2013, $54,5091$.

68. Vogel, A. I. F., B. S.; Hannaford, A. J.; Smith, P. W. G. ;Tatchell, A. R. Textbook of practical organic chemistry; 5th ed.; Prentice Hall: New York, 1996.

69. Sosic, I.; Barreteau, H.; Simcic, M.; Sink, R.; Cesar, J.; Zega, A.; Grdadolnik, S. G.; Contreras-Martel, C.; Dessen, A.; Amoroso, A.; Joris, B.; Blanot, D.; Gobec, S. Eur. J. Med. Chem. 2011, 46, 2880.

70. Keana, J. F. W.; Ordentlich, P.; Goodenow, R.; Syndax Pharmaceuticals, Inc., USA . 2009, p 166pp. 
71. Akhavan-tafti, H.; Eickholt, R. A.; Handley, R. S.; Lumigen, Inc., USA . 2001; Vol. US 2001/0031869A1.

72. Jiang, M.; Wang, Q.; Karasawa, T.; Koo, J. W.; Li, H.; Steyger, P. S. PLoS ONE 2014, 9, e108941.

73. Ou, H.; Simon, J. A.; Rubel, E. W.; Raible, D. W. Hear. Res. 2012, 288, 58.

74. Whitfield, T. T. J. Neurobiol. 2002, 53, 157.

75. Ernest, S.; Rauch, G. J.; Haffter, P.; Geisler, R.; Petit, C.; Nicolson, T. Hum. Mol. Genet. 2000, 9, 2189.

76. Ginos, J. Z.; Cooper, A. J.; Dhawan, V.; Lai, J. C.; Strother, S. C.; Alcock, N.; Rottenberg, D. A. J. Nucl. Med. 1987, 28, 1844.

77. Ning, S.; Yu, N.; Brown, D. M.; Kanekal, S.; Knox, S. J. Radiother. Oncol. 1999, $50,215$.

78. Ekborn, A.; Lindberg, A.; Laurell, G.; Wallin, I.; Eksborg, S.; Ehrsson, H. Cancer Chemother. Pharmacol. 2003, 51, 36.

79. Baldew, G. S.; Volkers, K. J.; De Goeij, J. J.; Vermeulen, N. P. J. Chromatogr. 1989, 491, 163.

80. Safaei, R.; Katano, K.; Larson, B. J.; Samimi, G.; Holzer, A. K.; Naerdemann, W.; Tomioka, M.; Goodman, M.; Howell, S. B. Clin. Cancer Res. 2005, 11, 756.

81. Heetebrij, R. J.; Talman, E. G.; Von Velzen, M. A.; Von Gijlswijk, R. P. M.; Snoeijers, S. S.; Schalk, M.; Wiegant, J.; Von der Rijke, F.; Kerkhoven, R. M.; Raap, A. K.; Tanke, H. J.; Reedijk, J.; Houthoff, H. J. Chembiochem 2003, 4, 573.

82. Dai, C. F.; Steyger, P. S. Hear. Res. 2008, 235, 114.

83. Benoist, E.; Loussouarn, A.; Remaud, P.; Chatal, J.-F.; Gestin, J.-F. Synthesis 1998, 1113.

84. Molenaar, C.; Teuben, J. M.; Heetebrij, R. J.; Tanke, H. J.; Reedijk, J. J Bio Inorg Chem 2000, 5, 655.

85. Gale, J. E.; Marcotti, W.; Kennedy, H. J.; Kros, C. J.; Richardson, G. P. J. Neurosci. 2001, 21, 7013.

86. Knox, R. J.; Friedlos, F.; Lydall, D. A.; Roberts, J. J. Cancer Res. 1986, 46, 1972. 
87. Thomas, J. P.; Lautermann, J.; Liedert, B.; Seiler, F.; Thomale, J. Mol. Pharmacol. 2006, 70, 23.

88. Qaddoumi, I.; Bass, J. K.; Wu, J.; Billups, C. A.; Wozniak, A. W.; Merchant, T. E.; Haik, B. G.; Wilson, M. W.; Rodriguez-Galindo, C. J. Clin. Oncol. 2012, 30, 1034.

89. Karasawa, T.; Sibrian-Vazquez, M.; Strongin, R. M.; Steyger, P. S. PLoS ONE 2013, 8, e66220.

90. Hall, J. R.; Appleton, T. G. Inorg. Chem. 1971, 10, 1717. 


\section{APPENDIX A: ${ }^{1} \mathrm{H}$ NMR, ${ }^{13} \mathrm{C}$ NMR AND MS SPECTRA FOR SELECTED COMPOUNDS FROM CHAPTER 1}

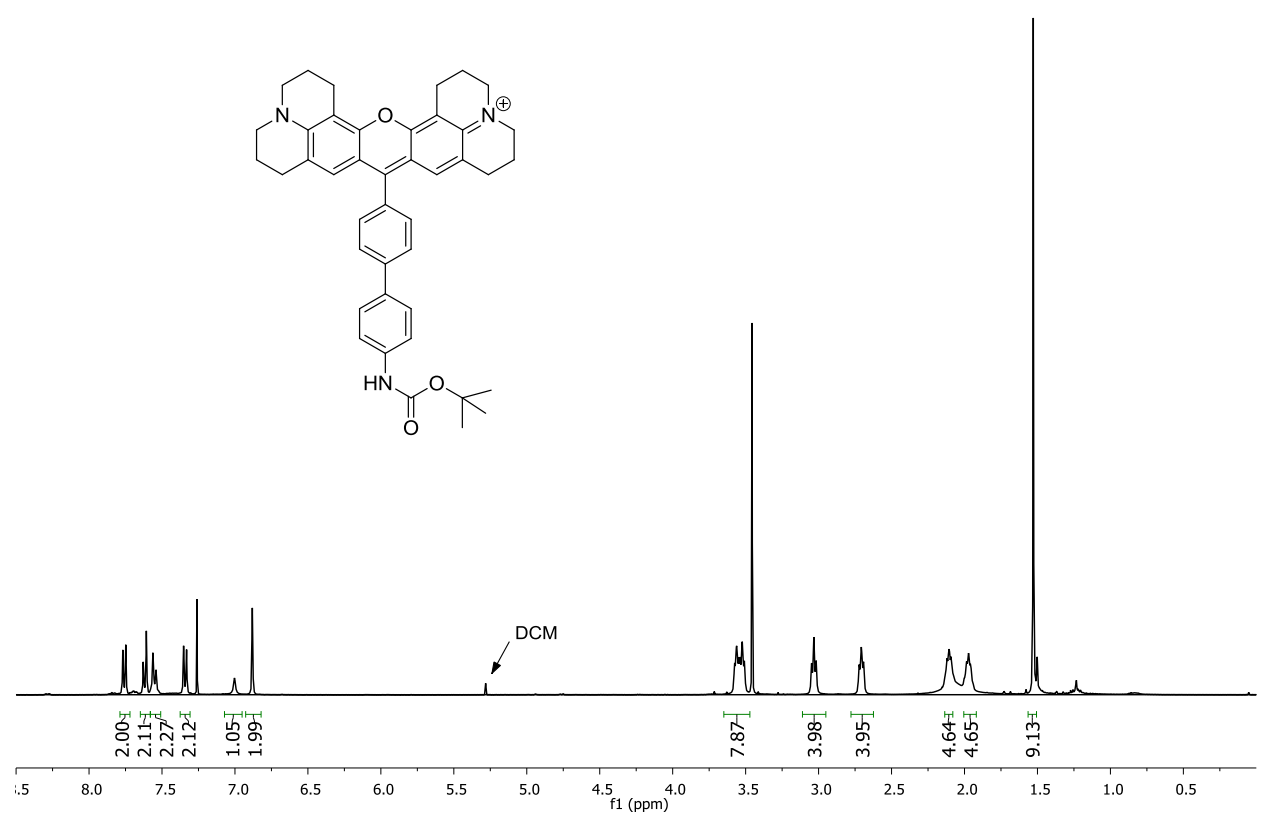

${ }^{1} \mathrm{H}$ NMR of compound 2.12

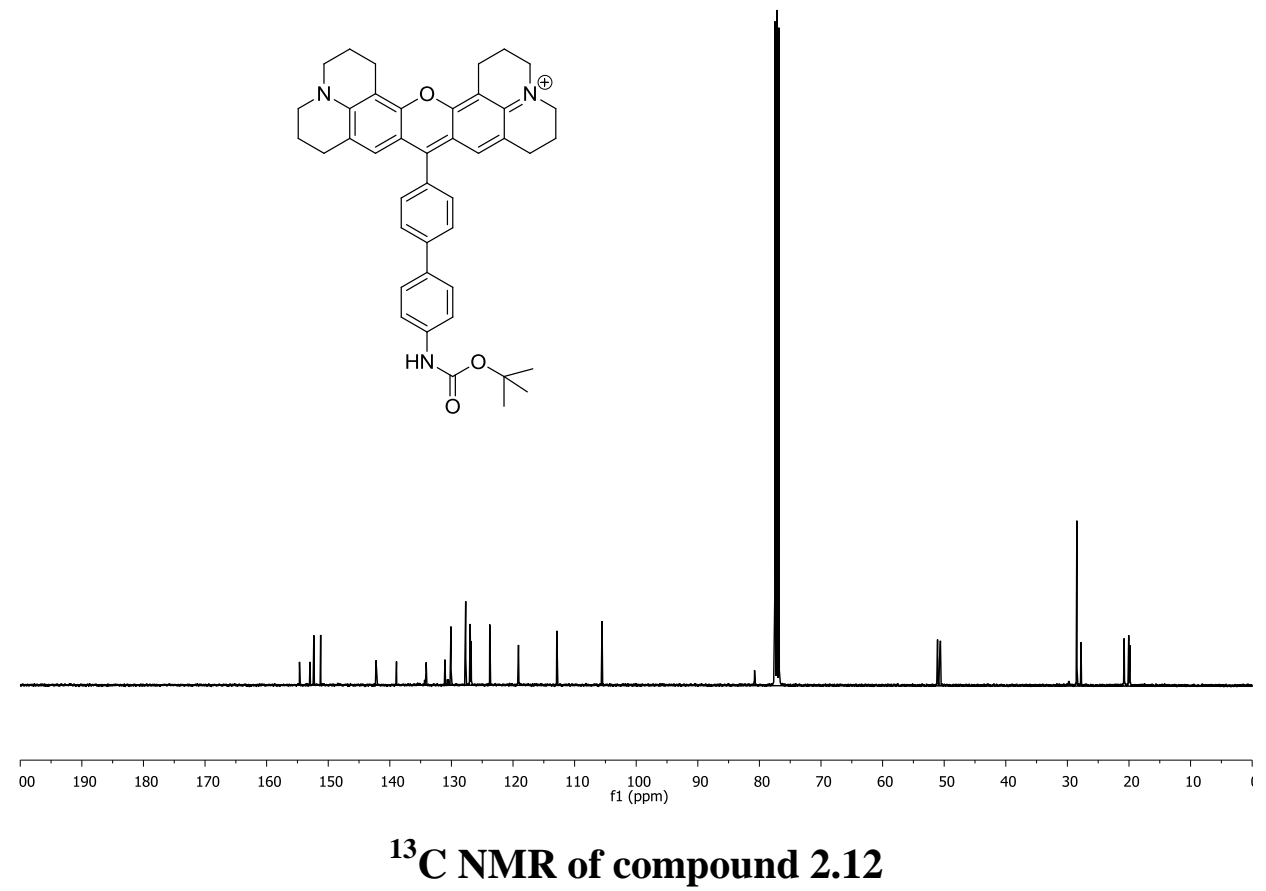




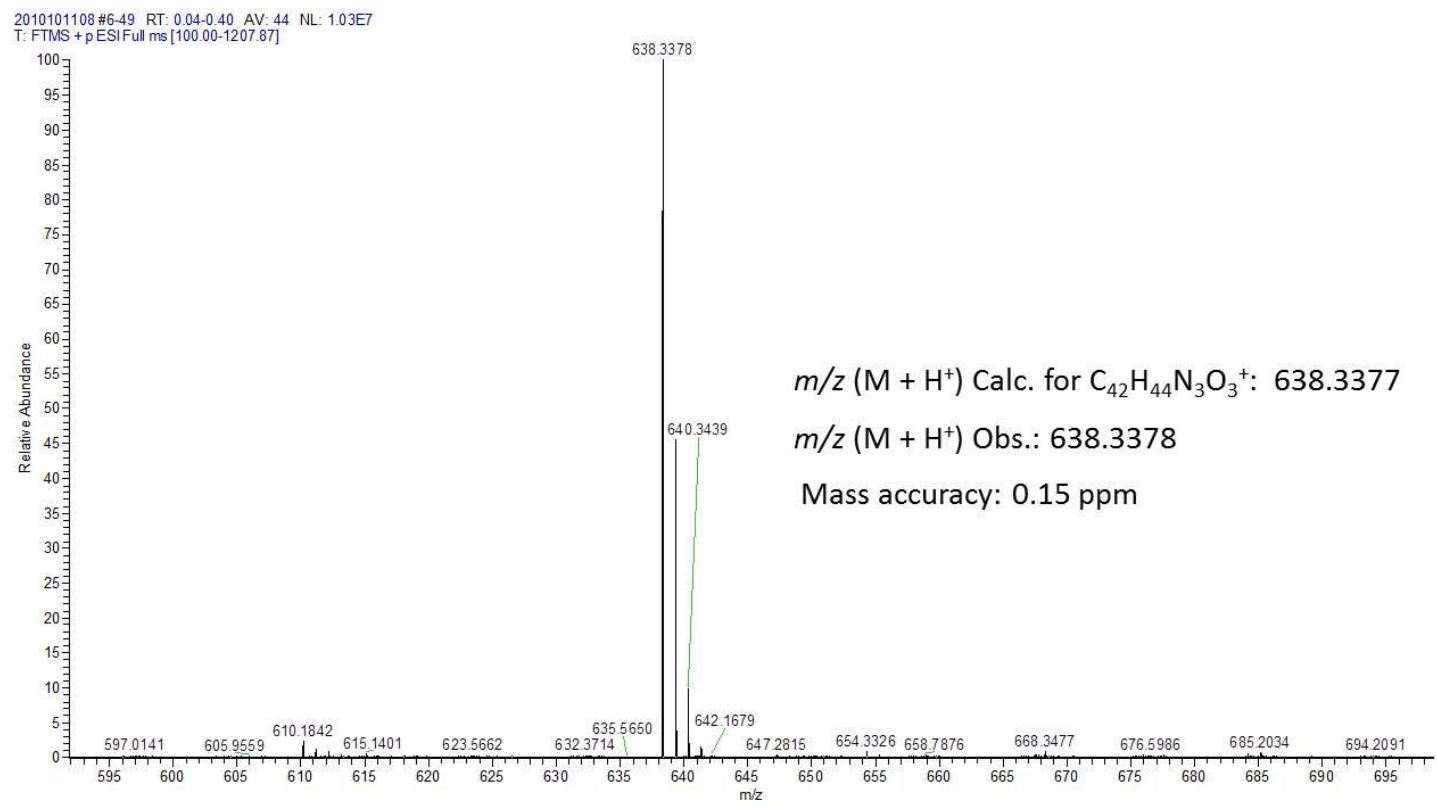

MS of compound 2.12
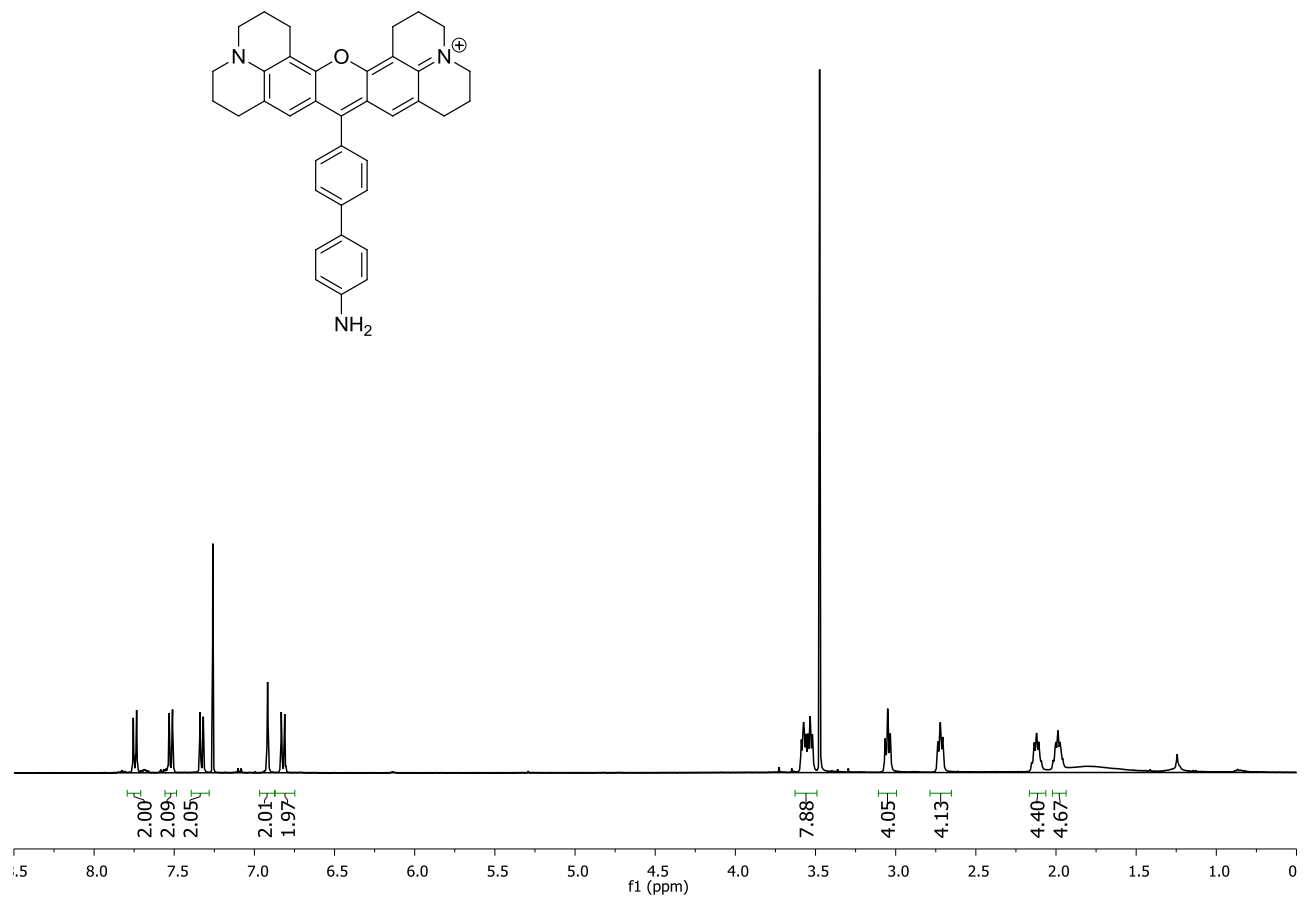

${ }^{1}$ H NMR of compound 2.13 


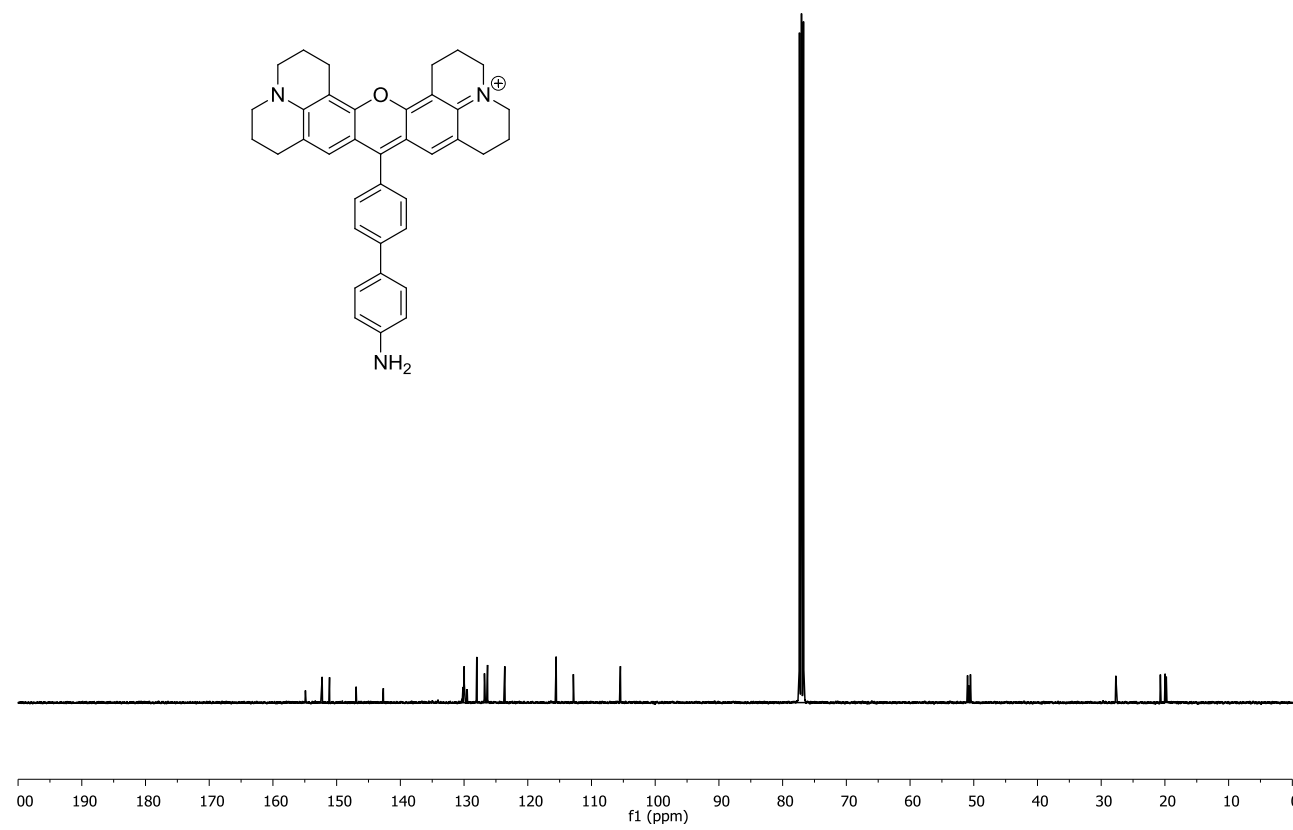

\section{${ }^{13} \mathrm{C}$ NMR of compound 2.13}

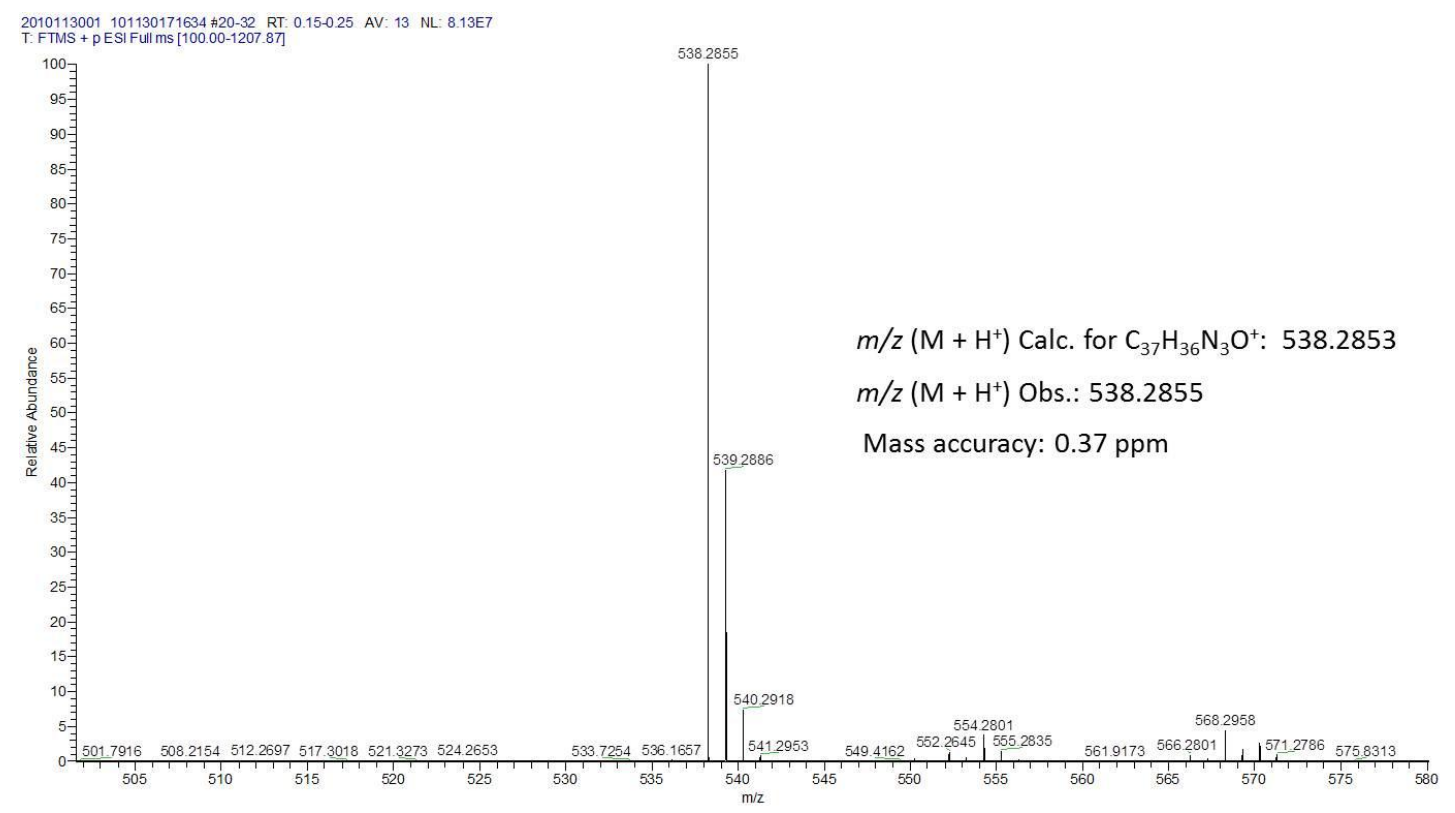

MS of compound 2.13 


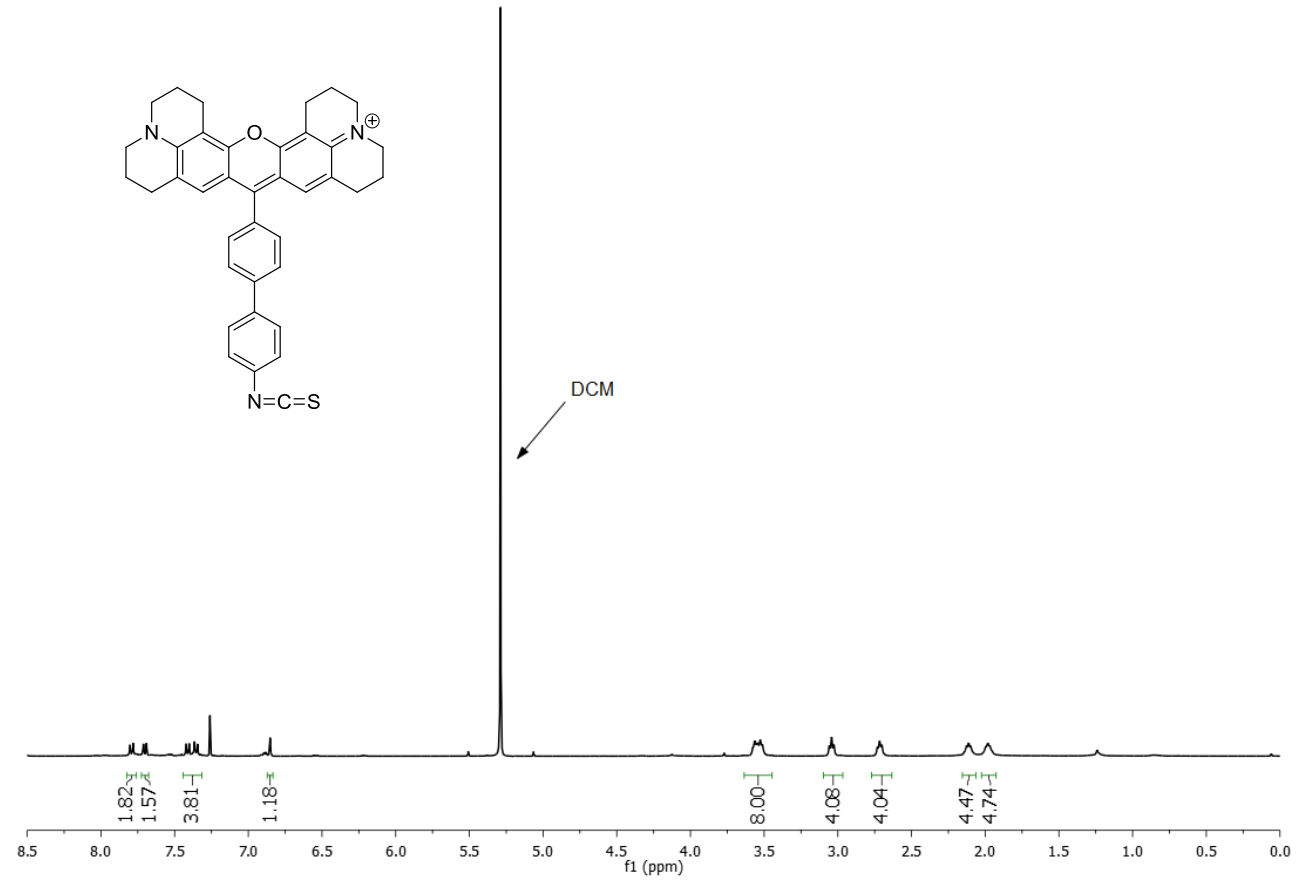

${ }^{1} \mathrm{H}$ NMR of compound 2.6

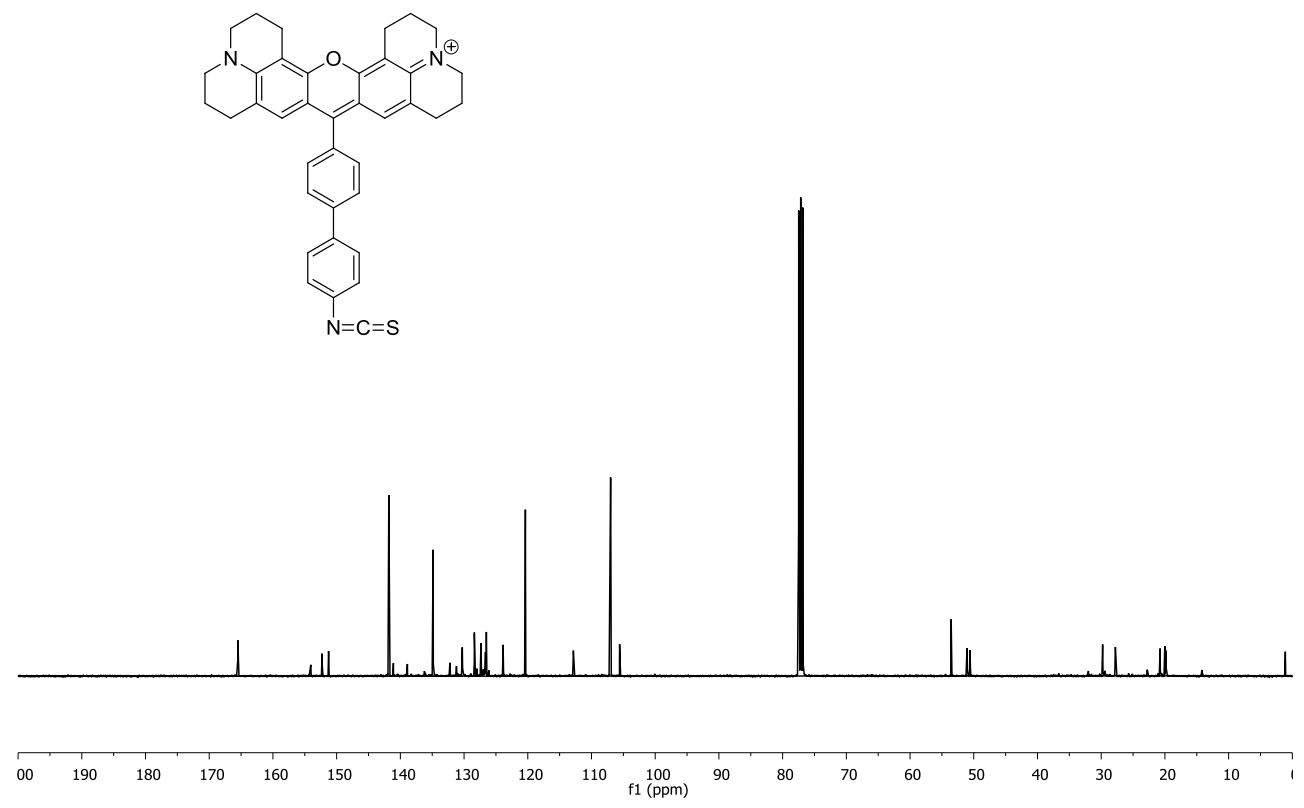

${ }^{13} \mathrm{C}$ NMR of compound 2.6 


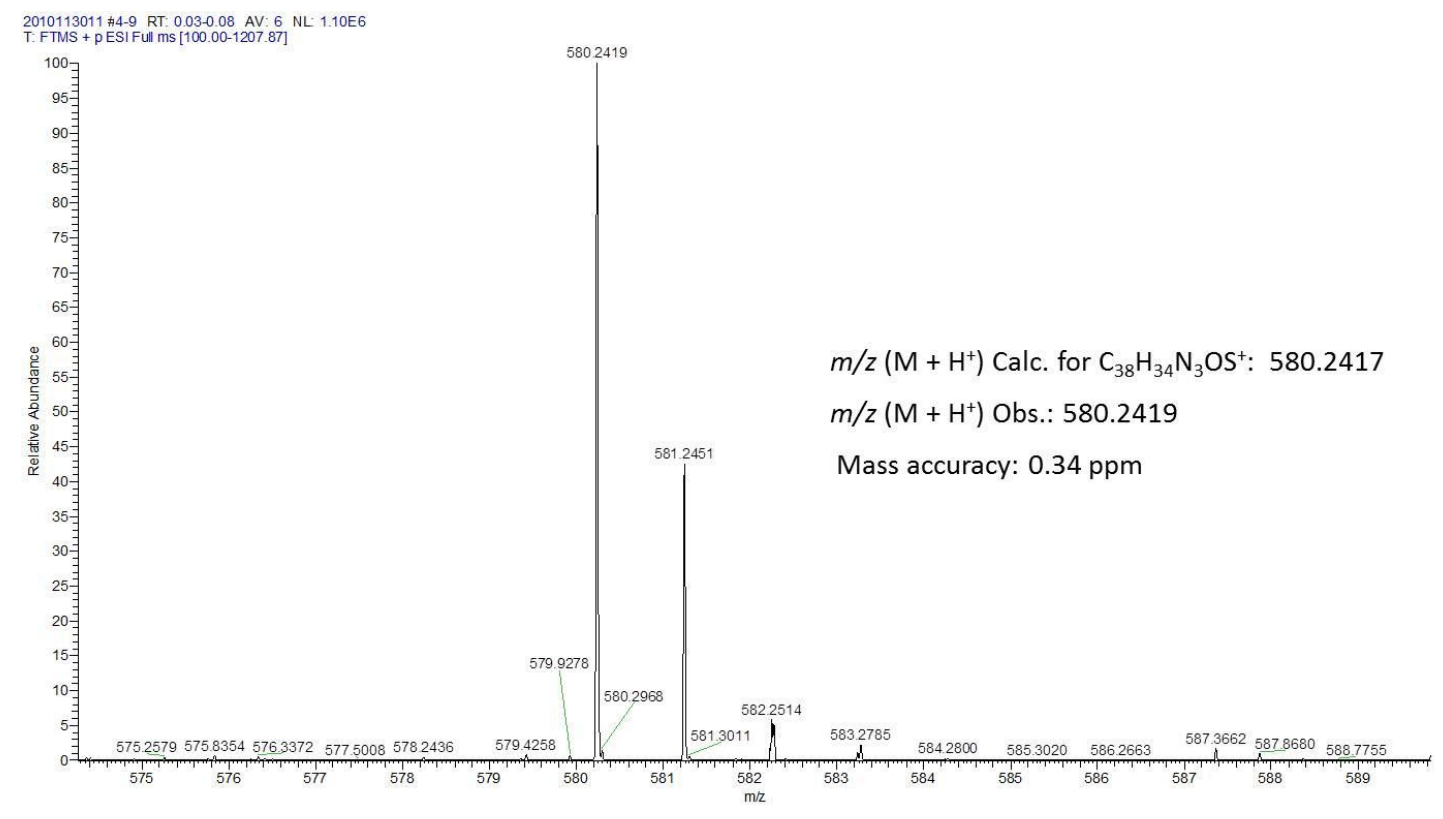

MS of compound 2.6
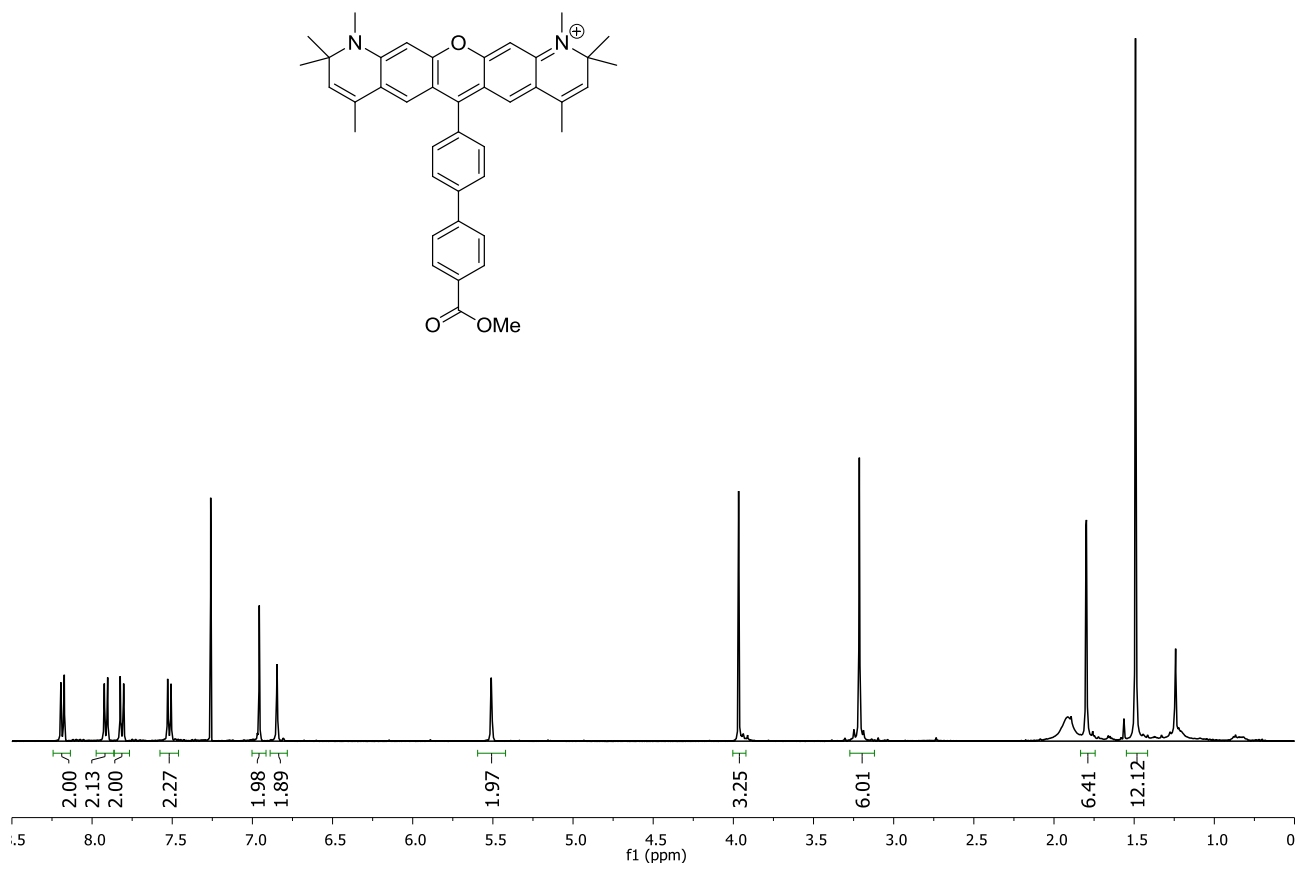

${ }^{1} \mathrm{H}$ NMR of compound 2.19 


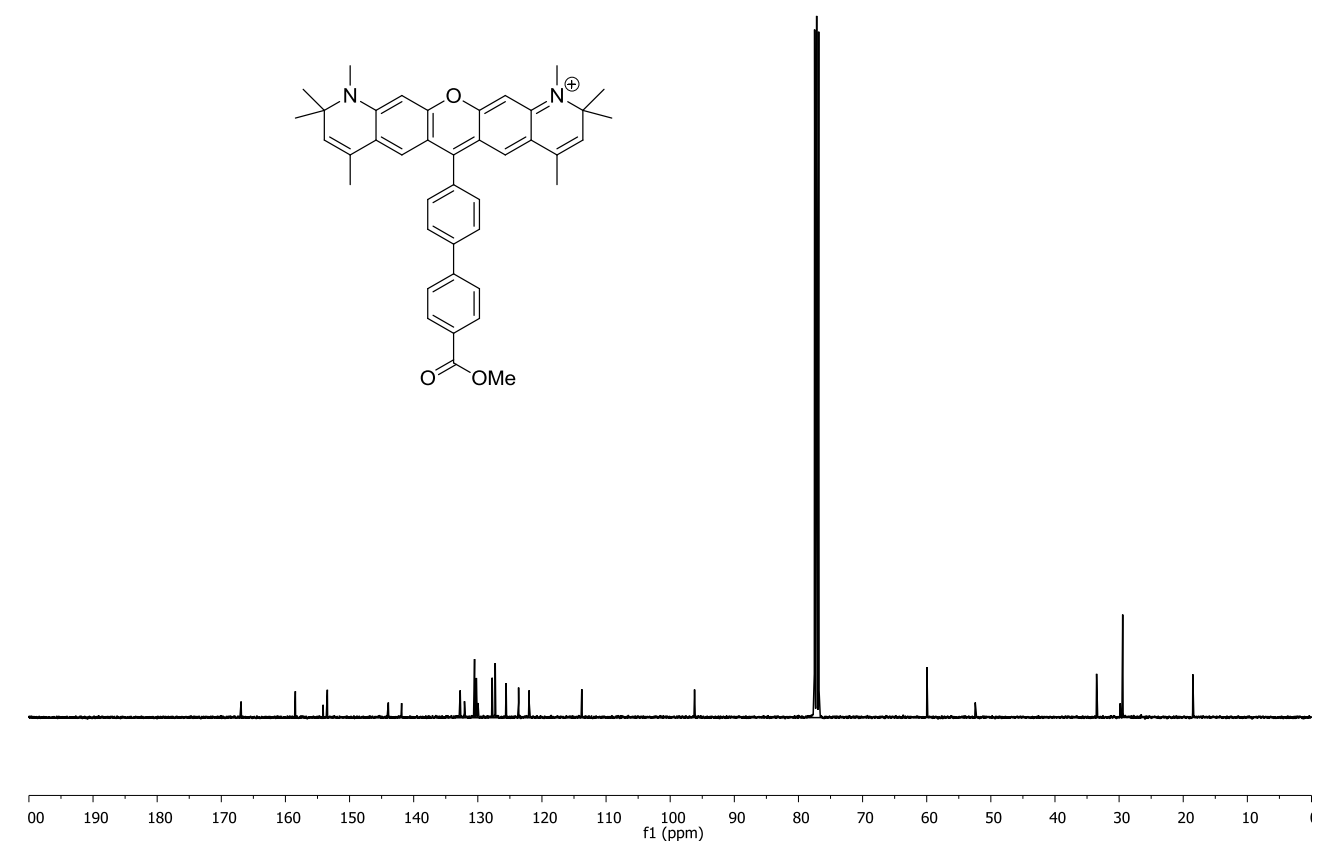

${ }^{13} \mathrm{C}$ NMR of compound 2.19

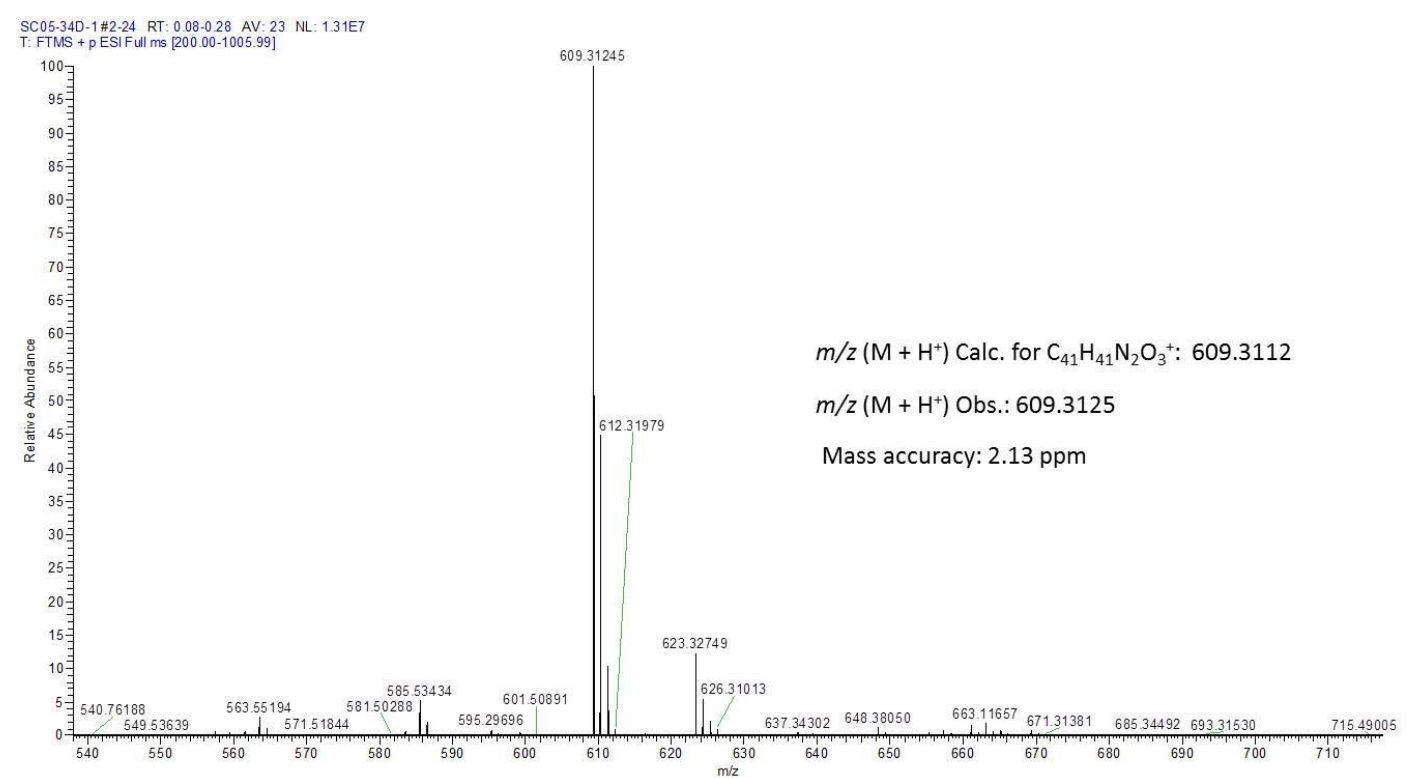

MS of compound 2.19 


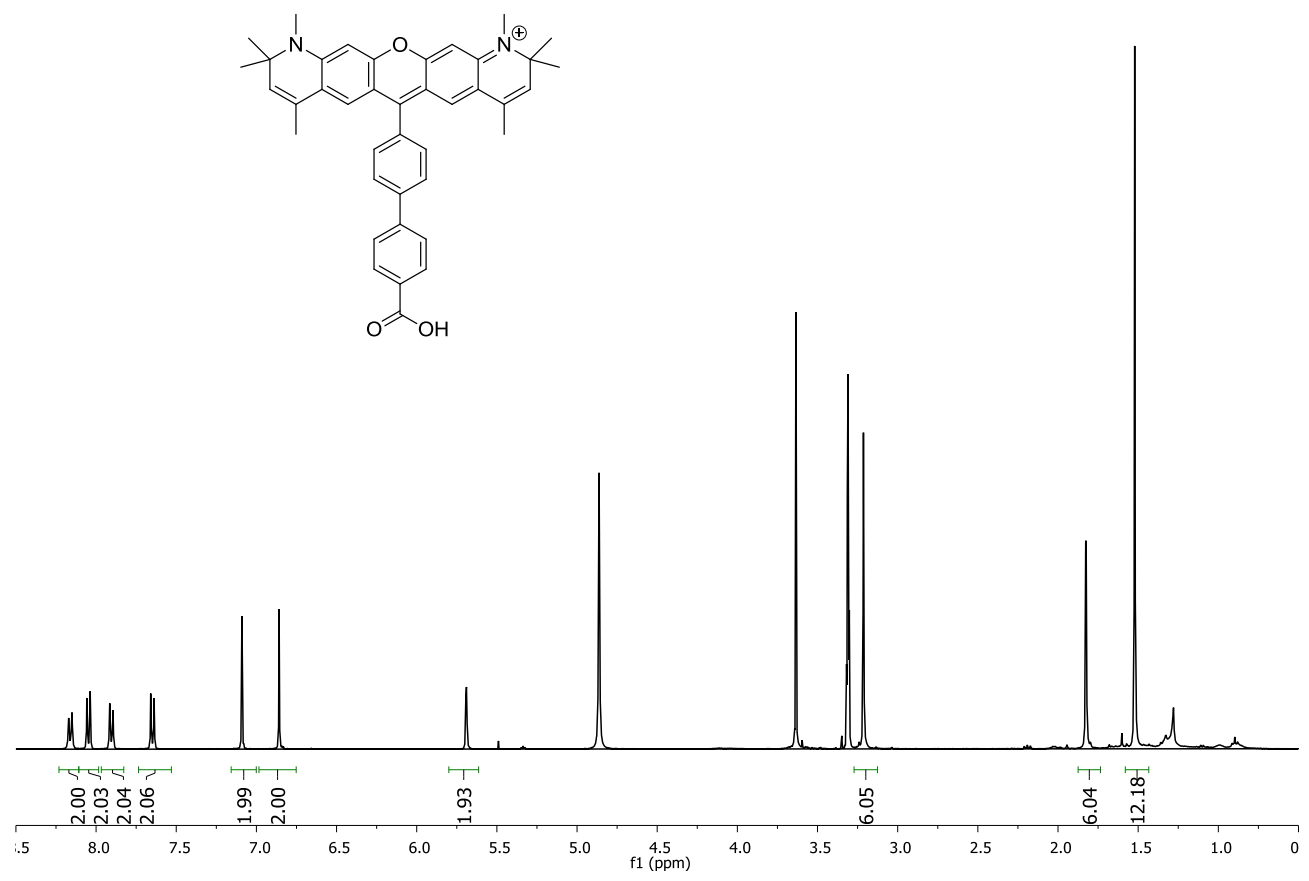

${ }^{1}$ H NMR of compound 2.21

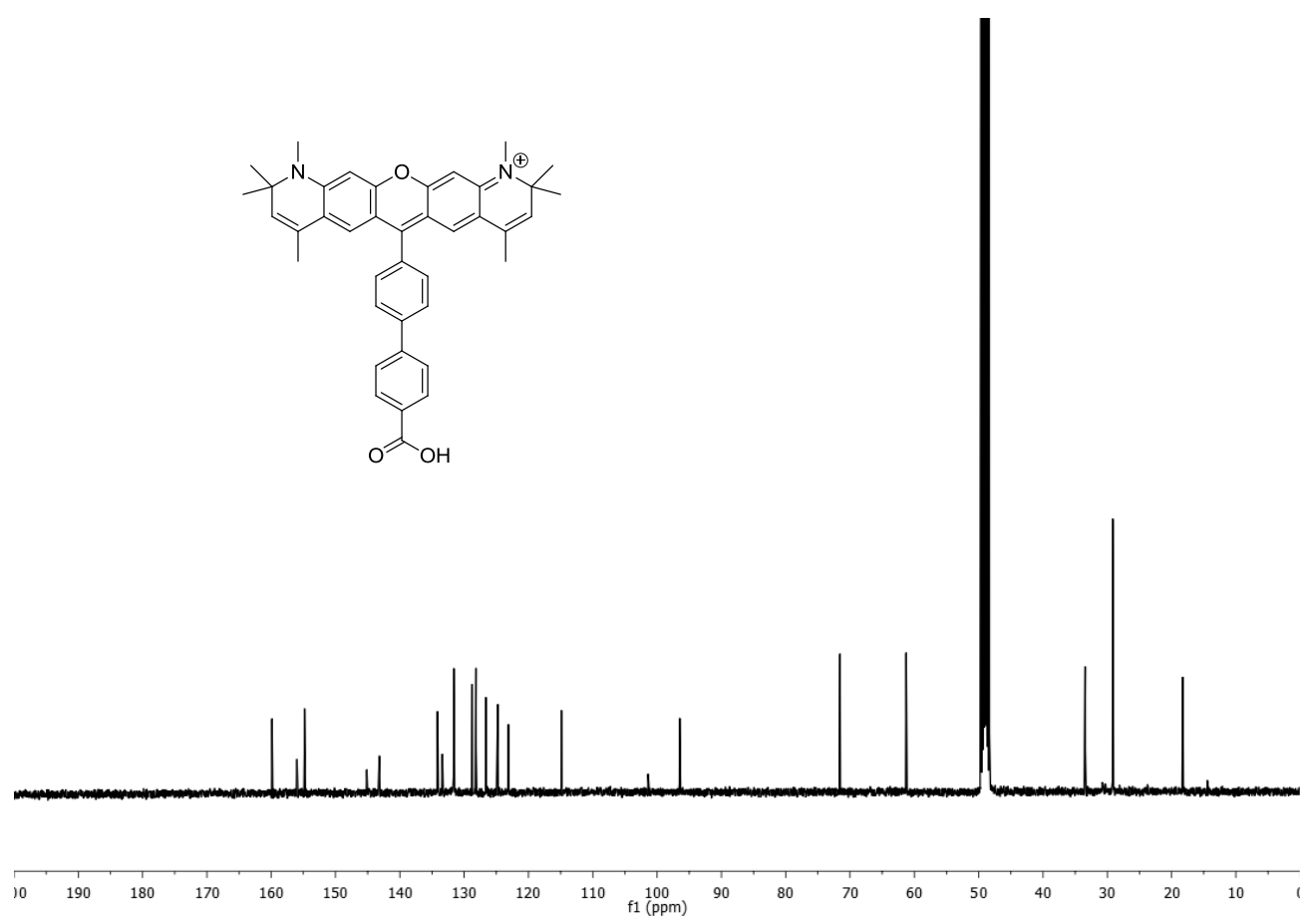

${ }^{13} \mathrm{C}$ NMR of compound 2.21 


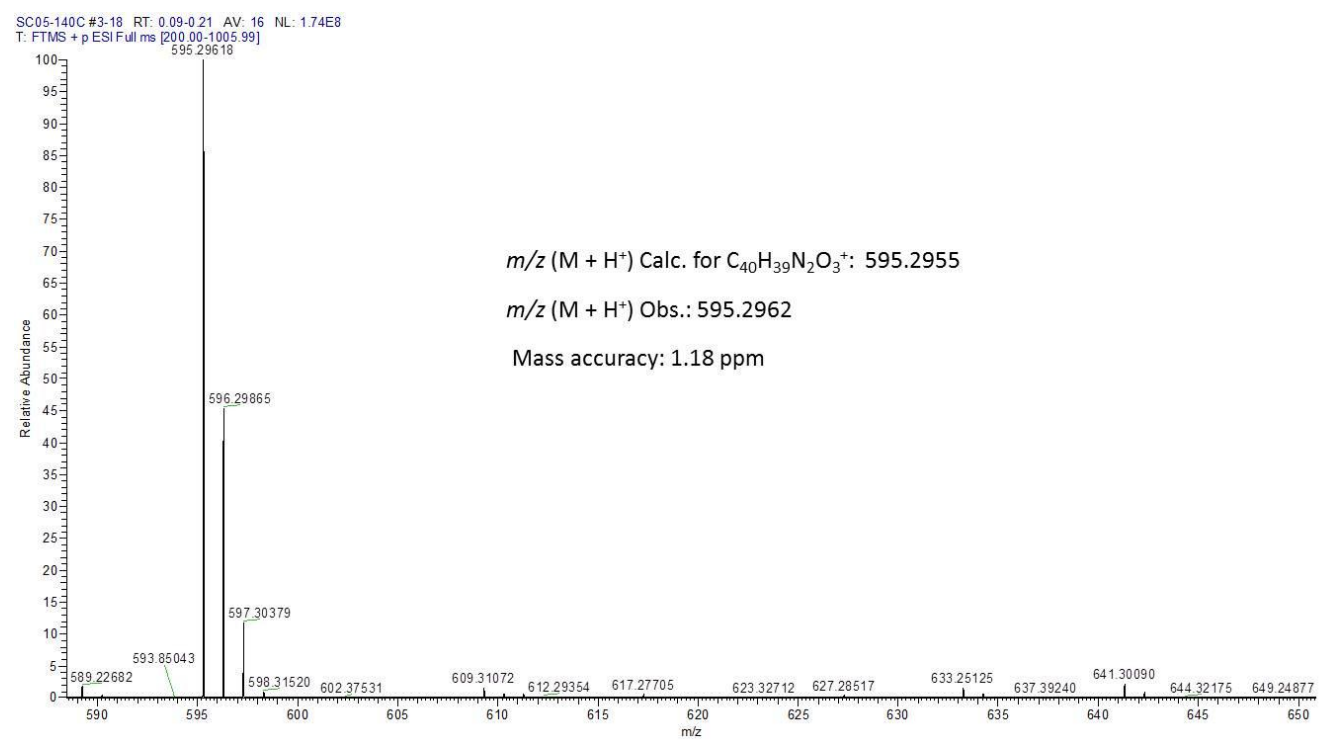

MS of compound 2.21
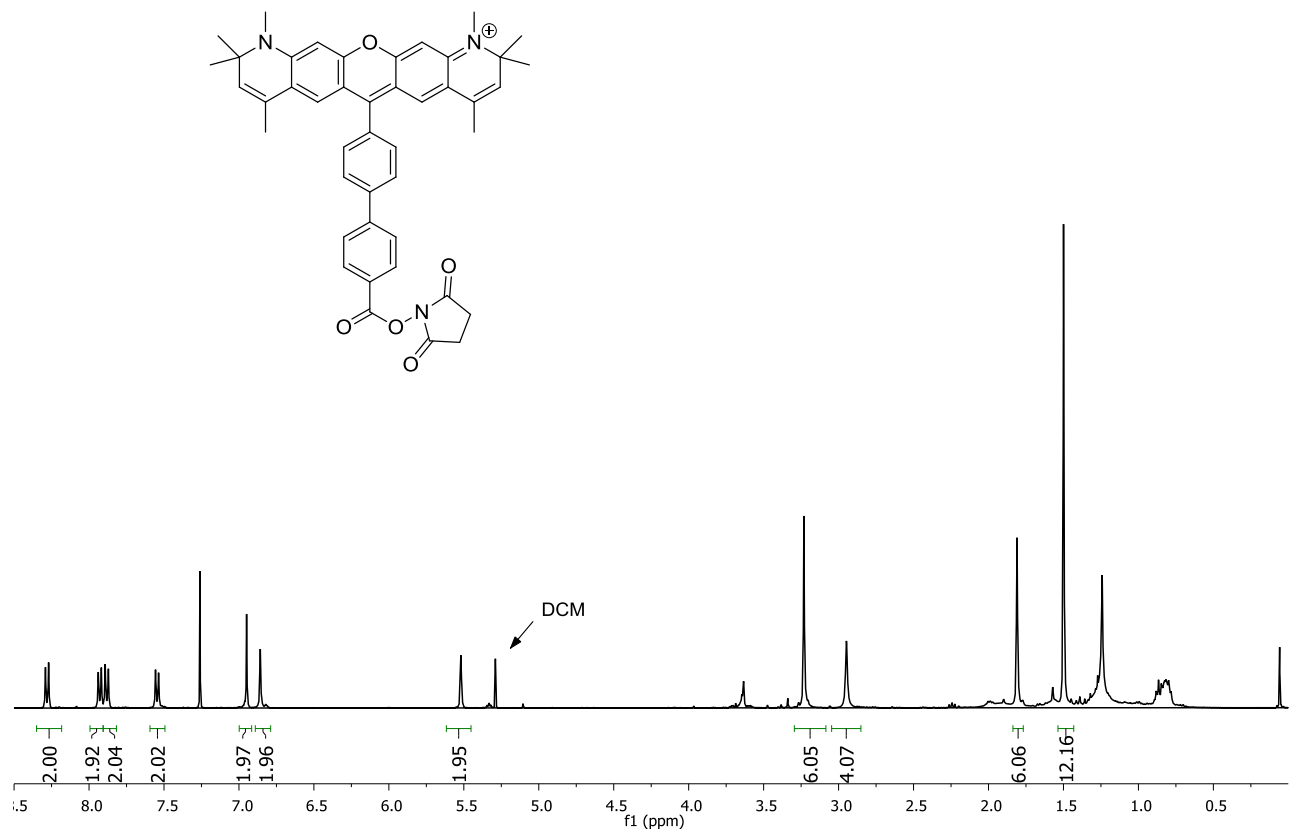

\section{${ }^{1} \mathrm{H}$ NMR of compound 2.7}



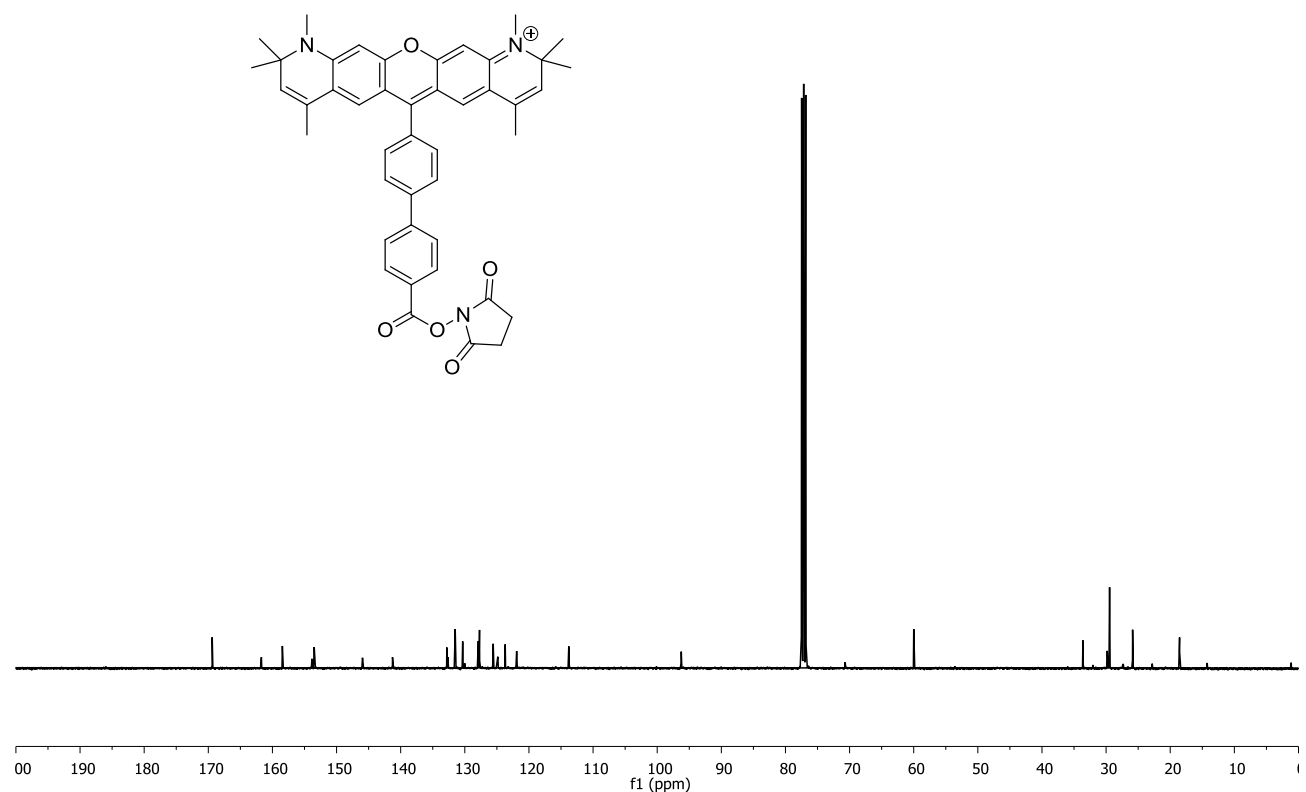

\section{${ }^{13} \mathrm{C}$ NMR of compound 2.7}

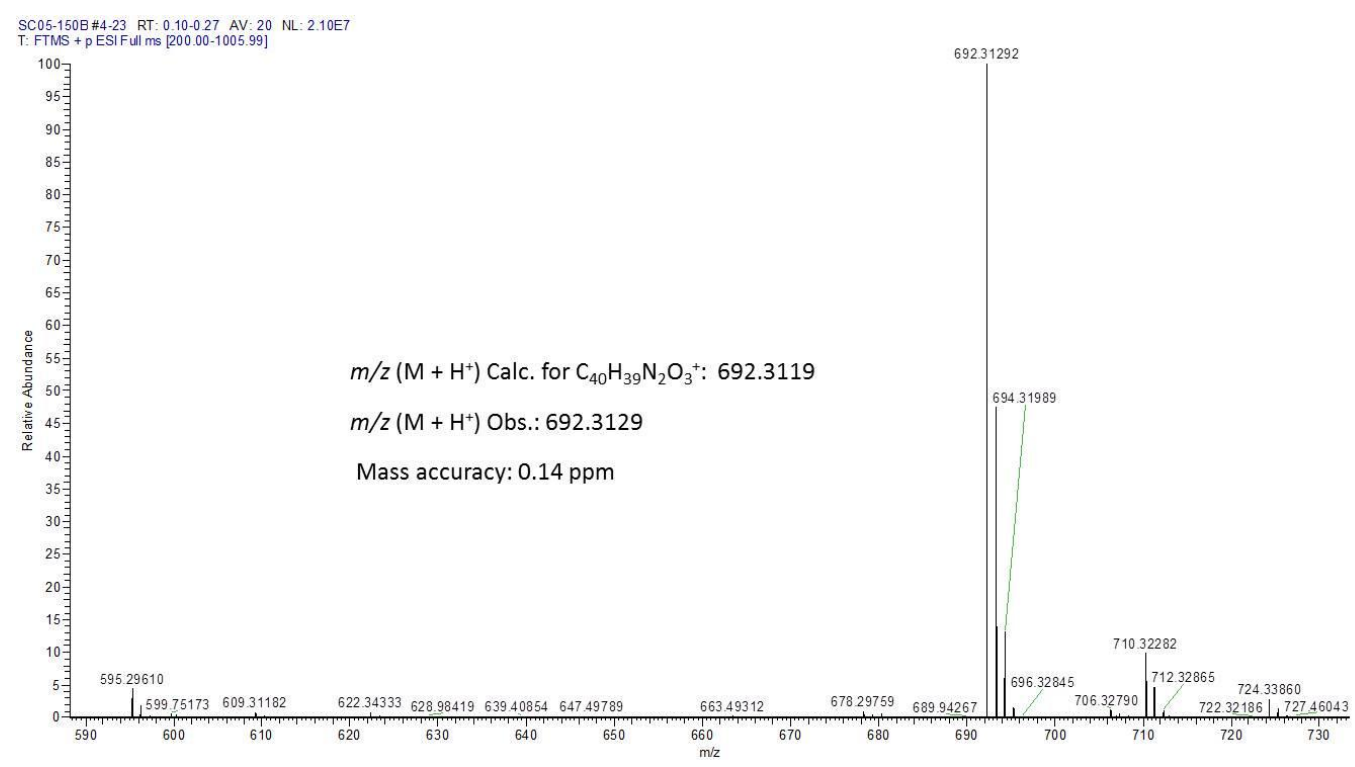

MS of compound 2.7 


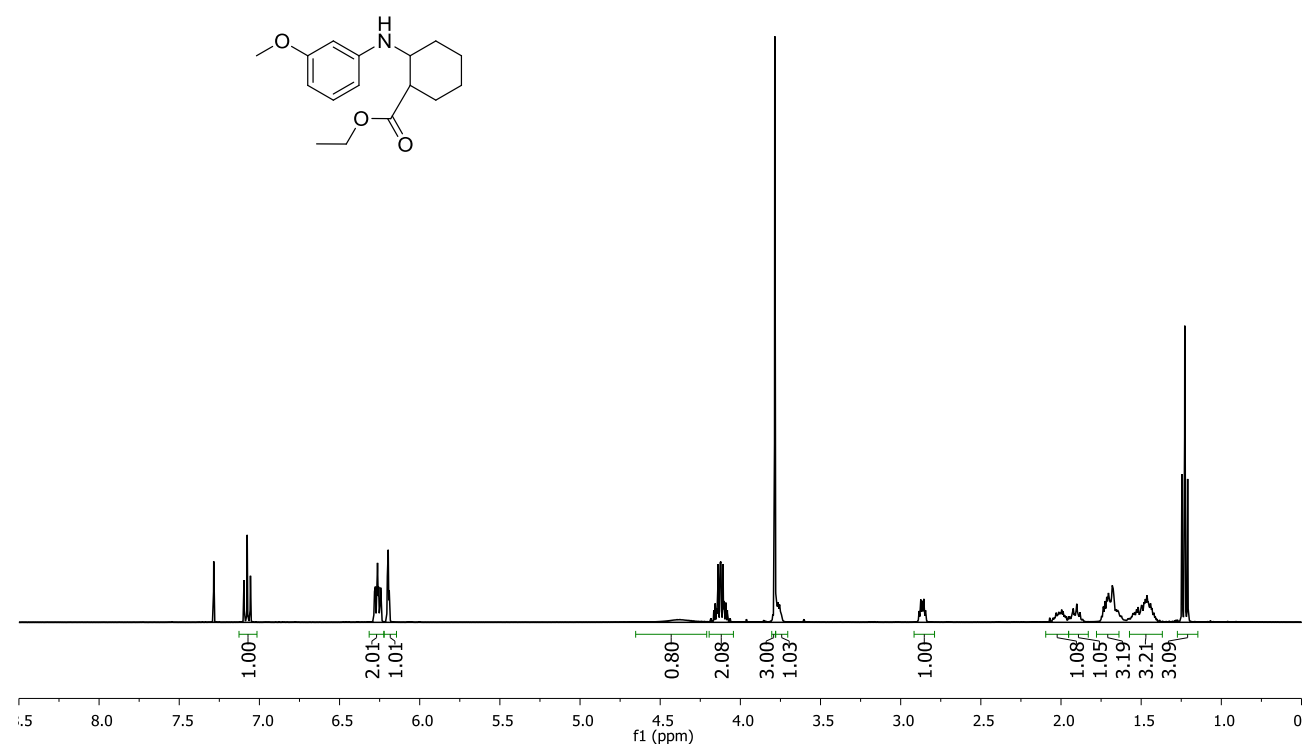

${ }^{1} \mathrm{H}$ NMR of compound 2.43
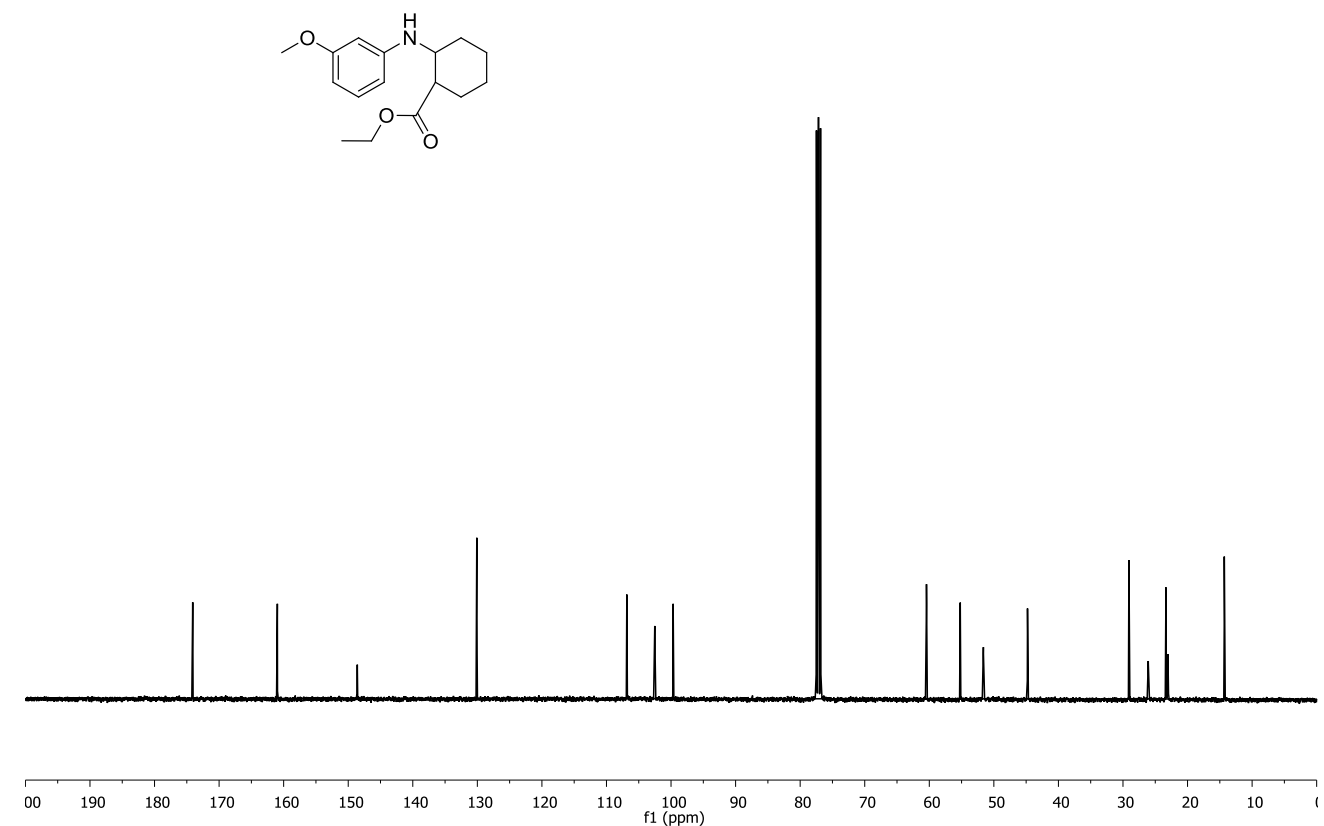

${ }^{13} \mathrm{C}$ NMR of compound 2.43 


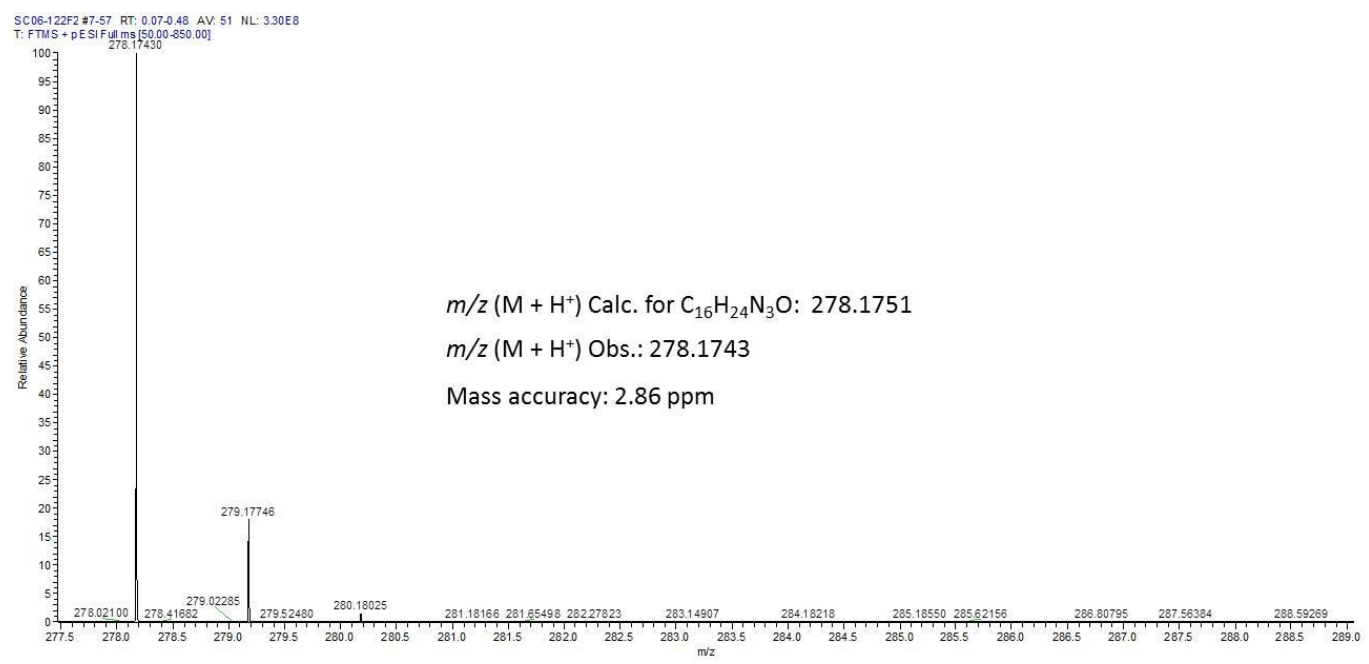

MS of compound 2.43

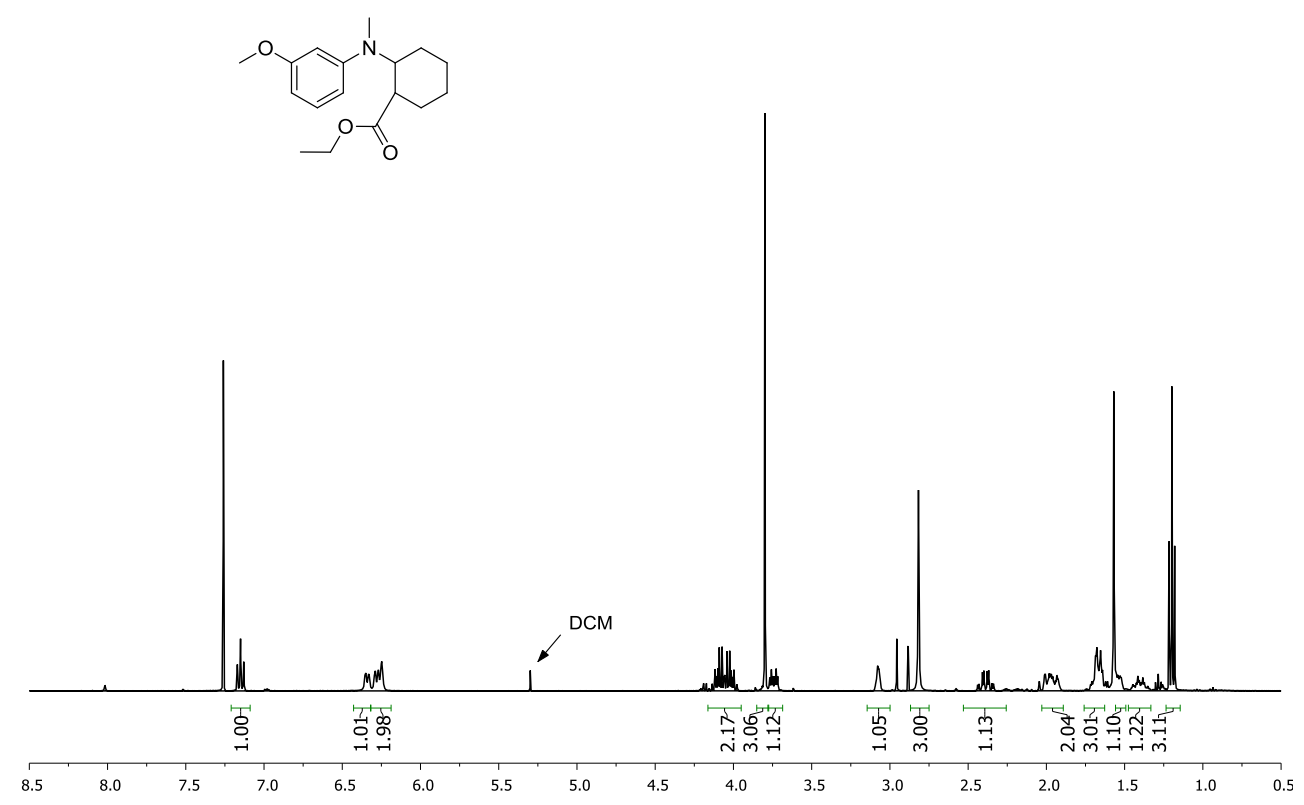

${ }^{1}$ H NMR of compound 2.44 

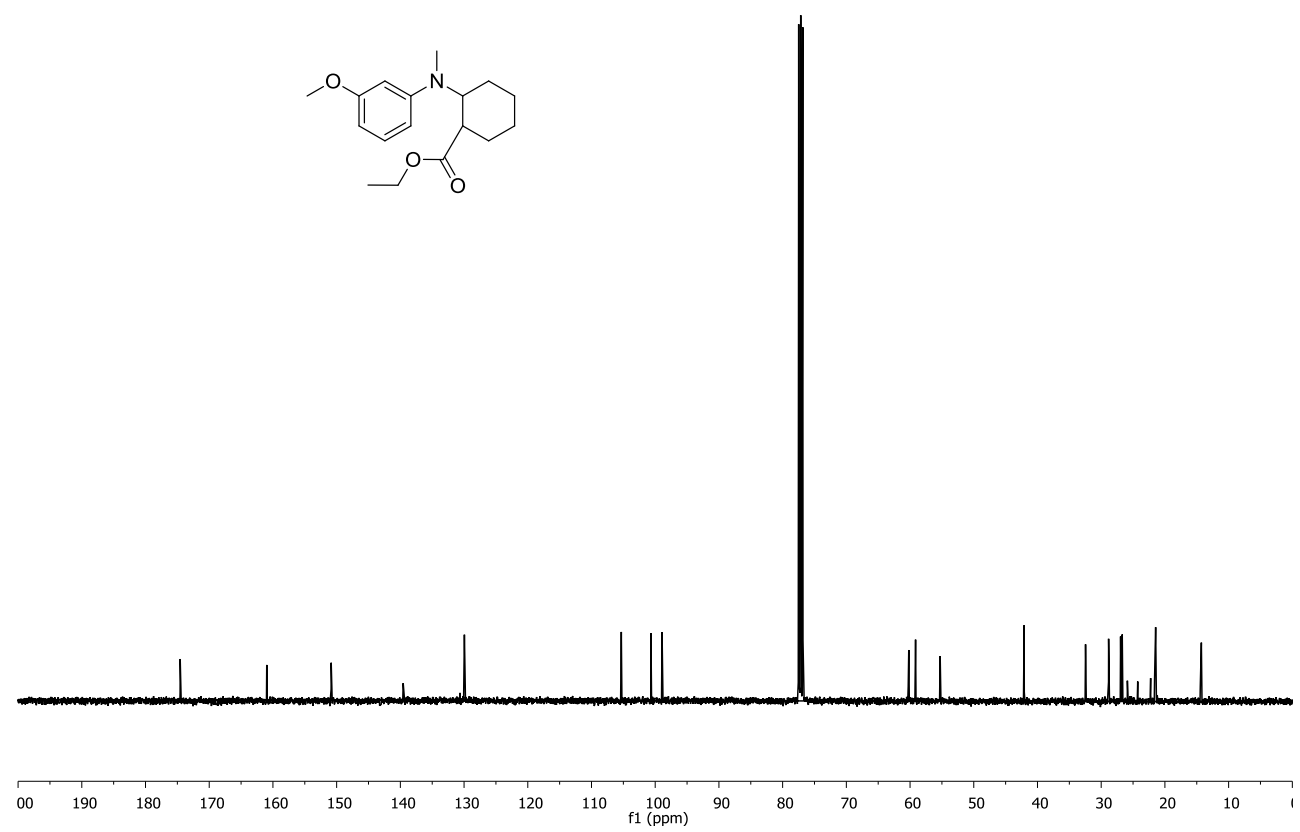

${ }^{13} \mathrm{C}$ NMR of compound 2.44

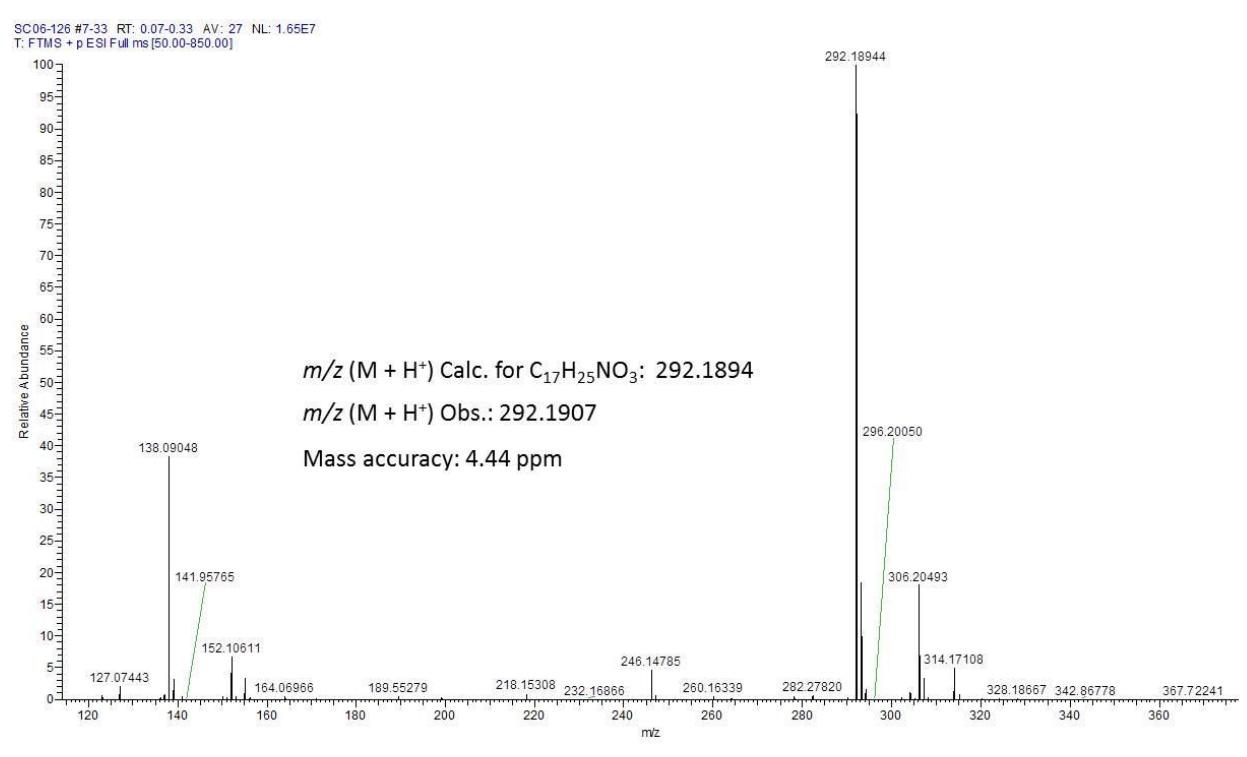

MSR of compound 2.44 


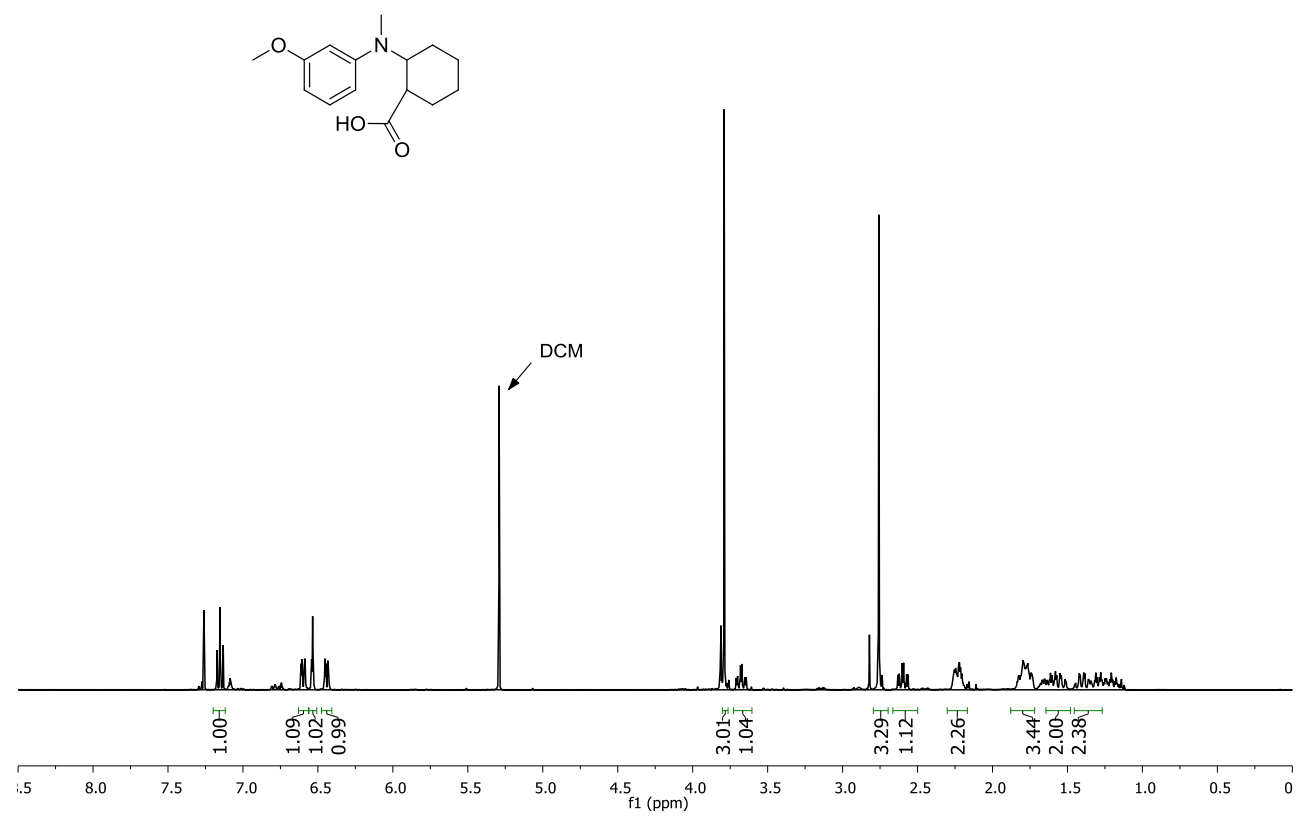

${ }^{1} \mathrm{H}$ NMR of compound 2.40
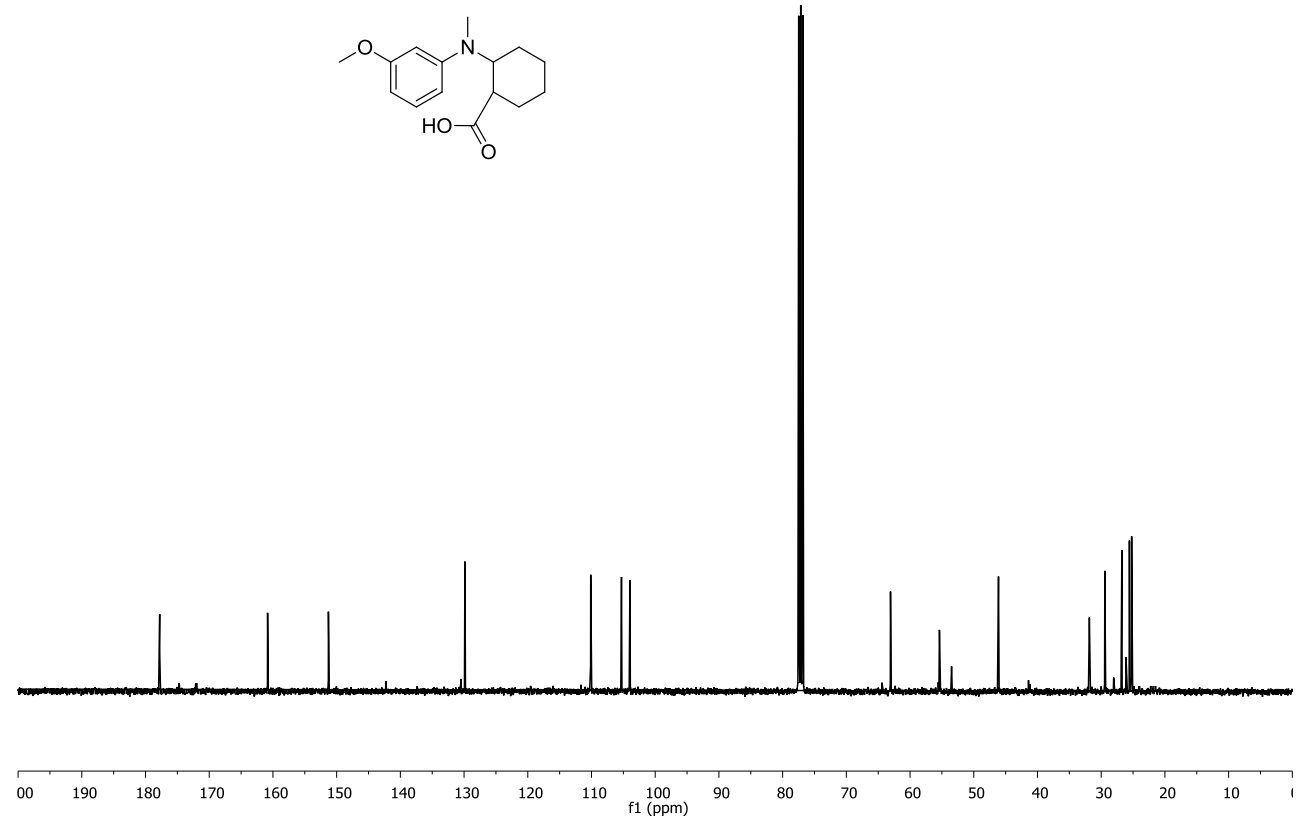

${ }^{13} \mathrm{C}$ NMR of compound 2.40 


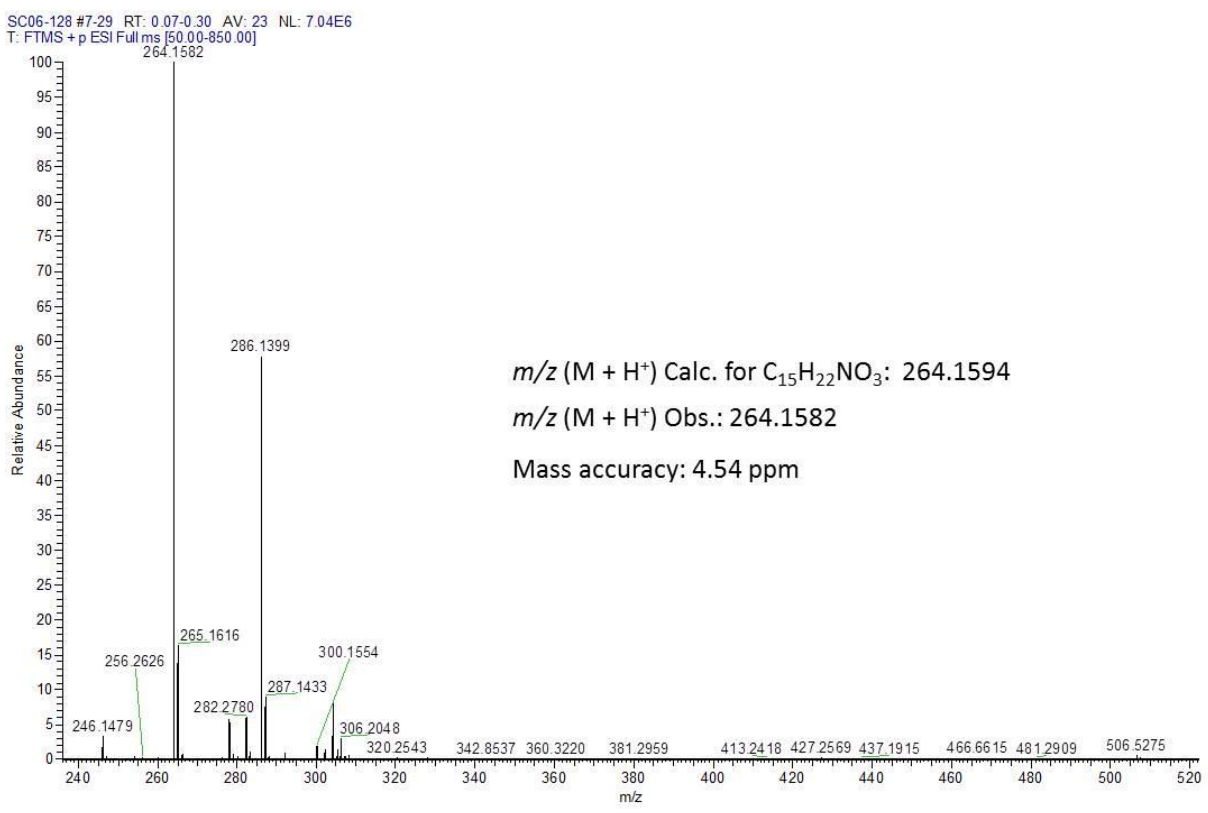

MS of compound 2.40

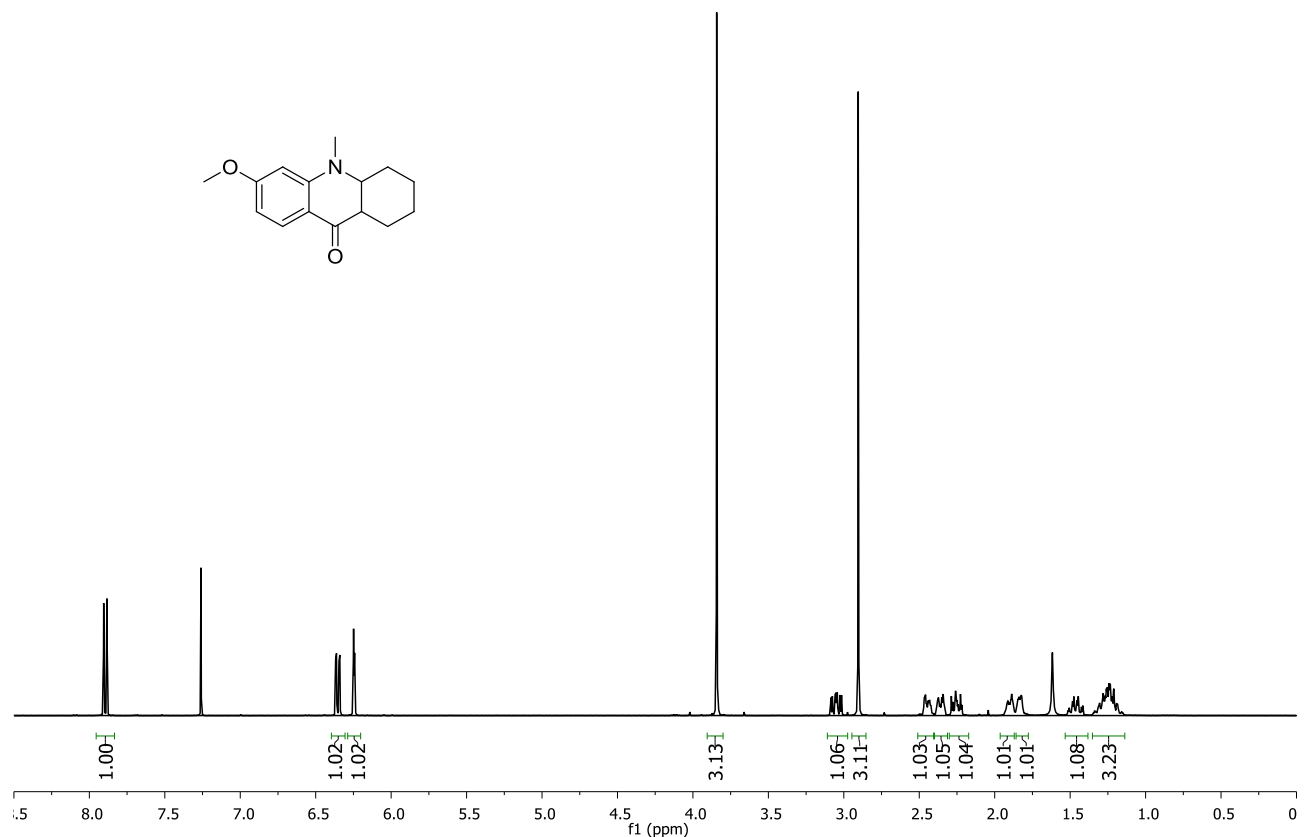

${ }^{1}$ H NMR of compound 2.34 


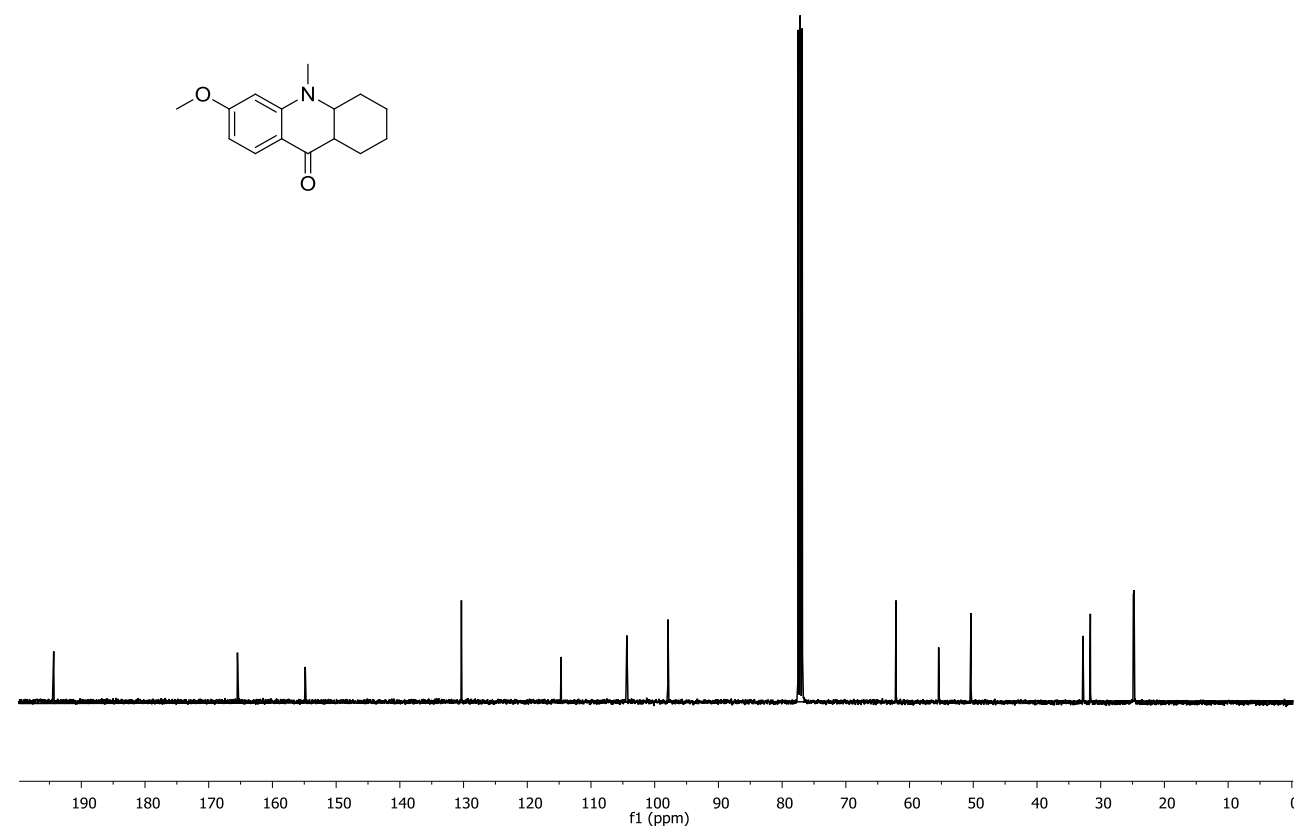

${ }^{13} \mathrm{C}$ NMR of compound 2.34

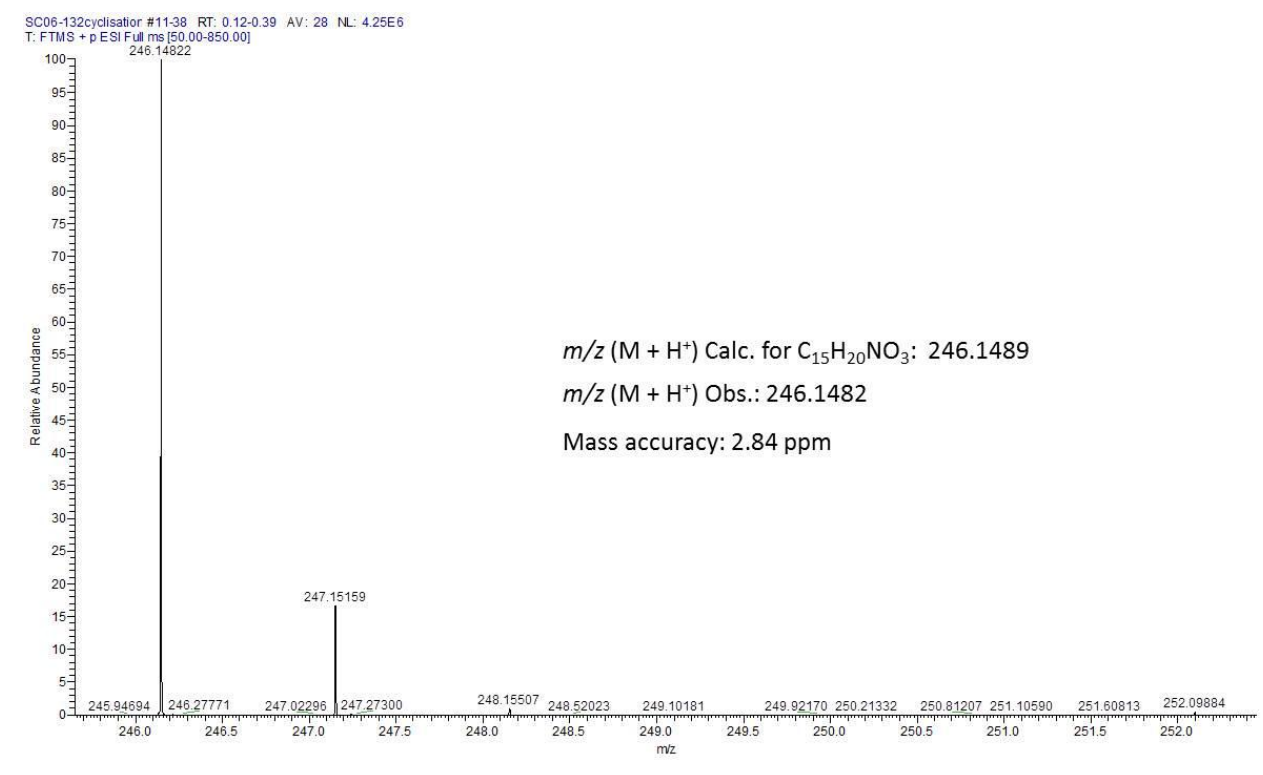

MS of compound 2.34 


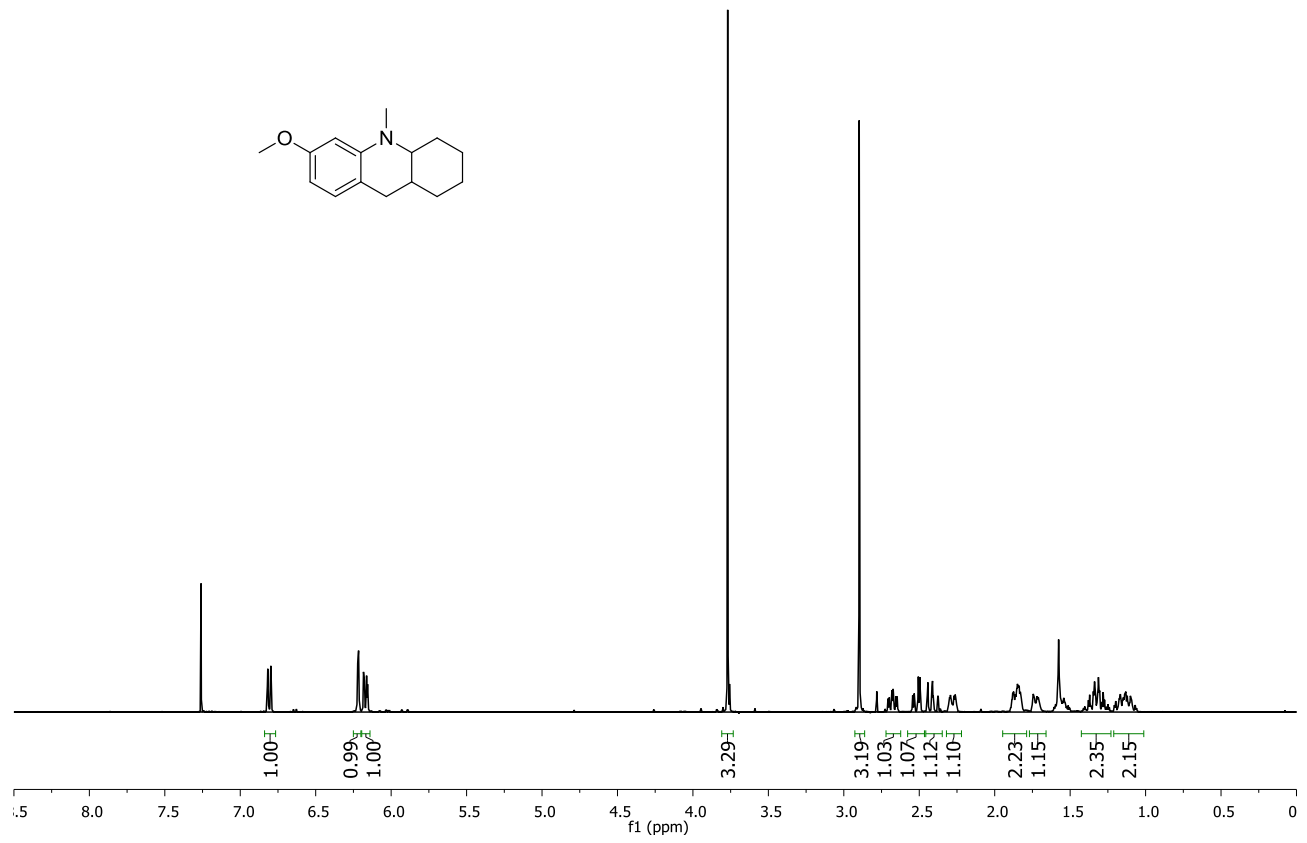

${ }^{1}$ H NMR of compound 2.33

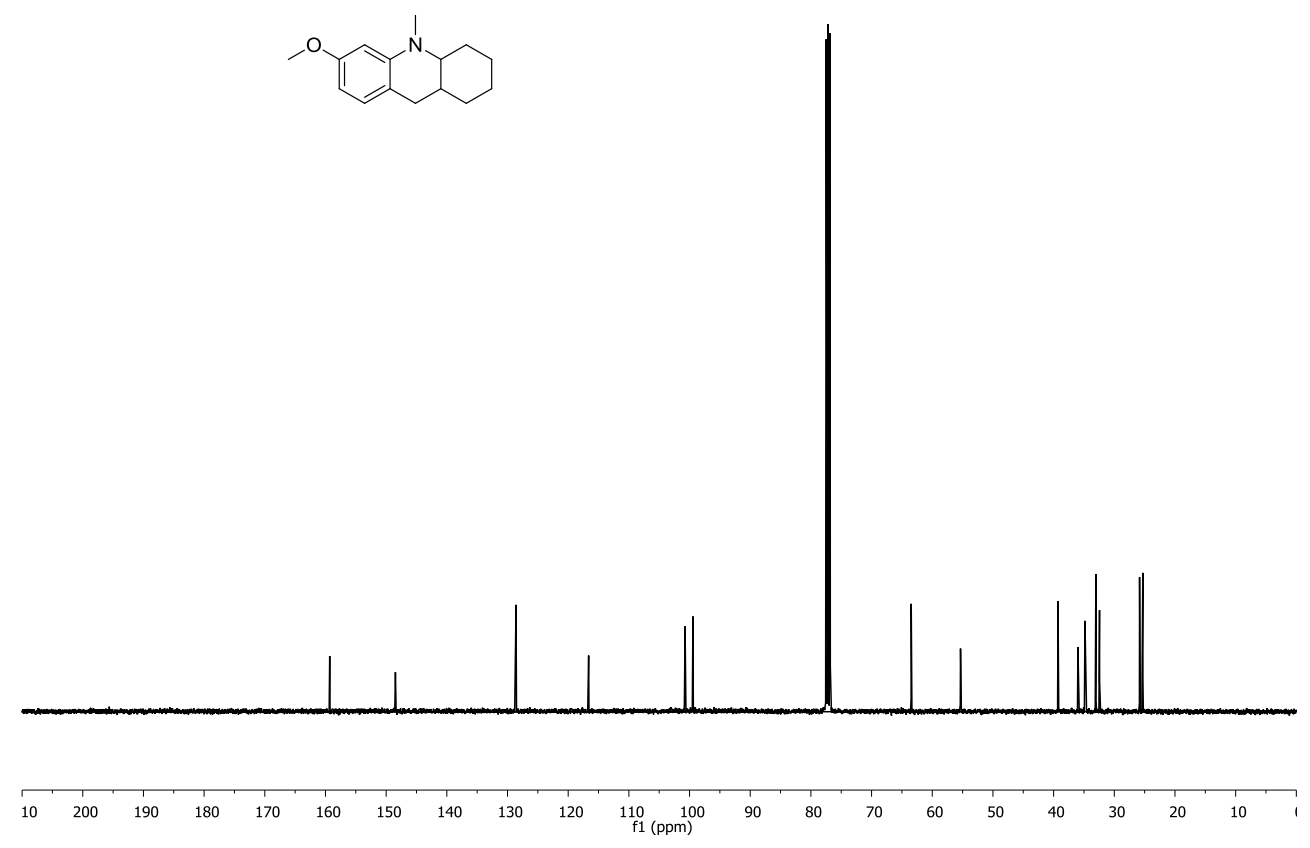

${ }^{13} \mathrm{C}$ NMR of compound 2.33

94 


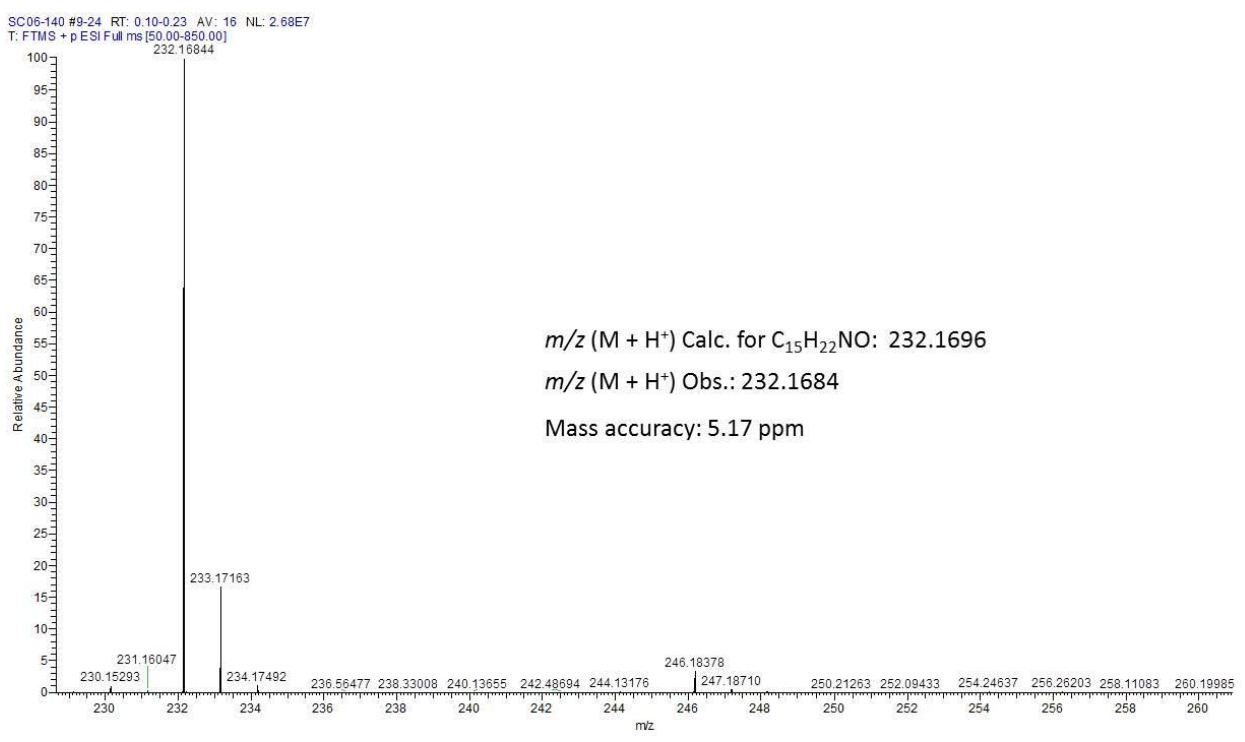

MS of compound 2.33

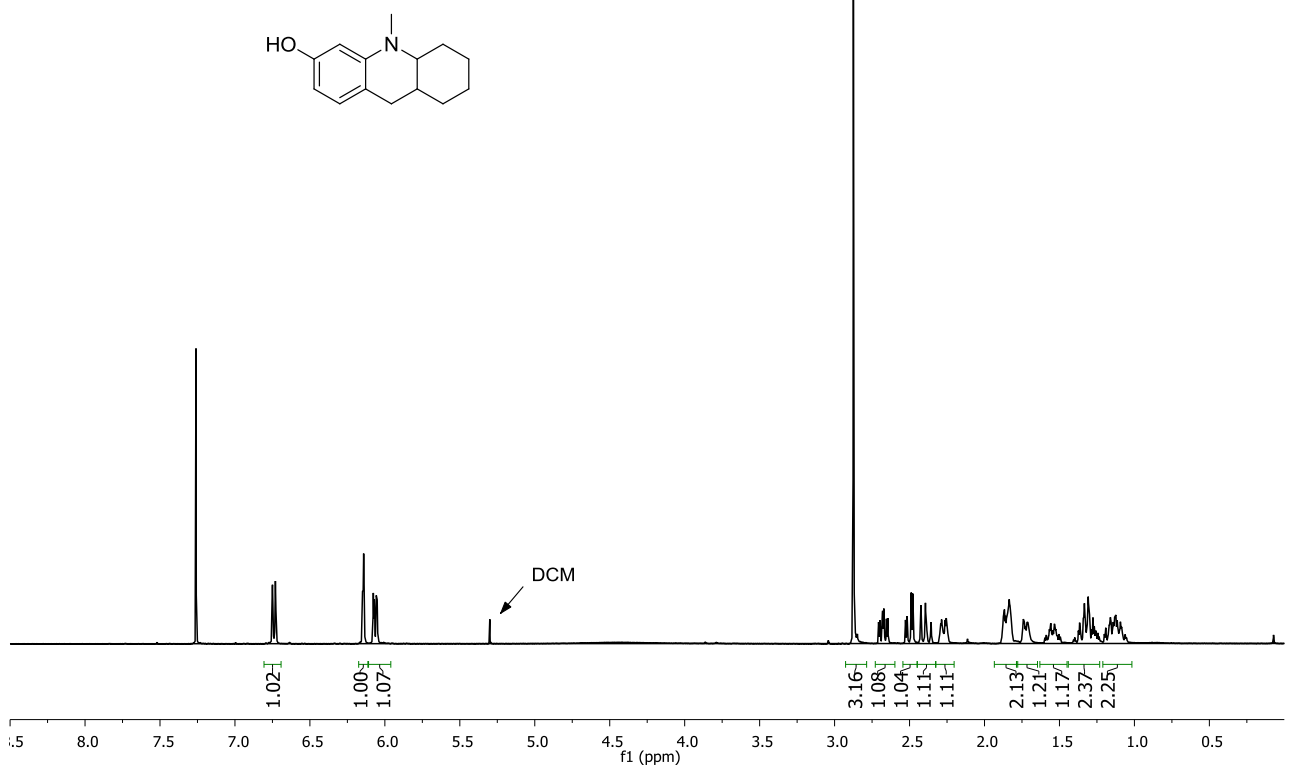

${ }^{1}$ H NMR of compound 2.32 


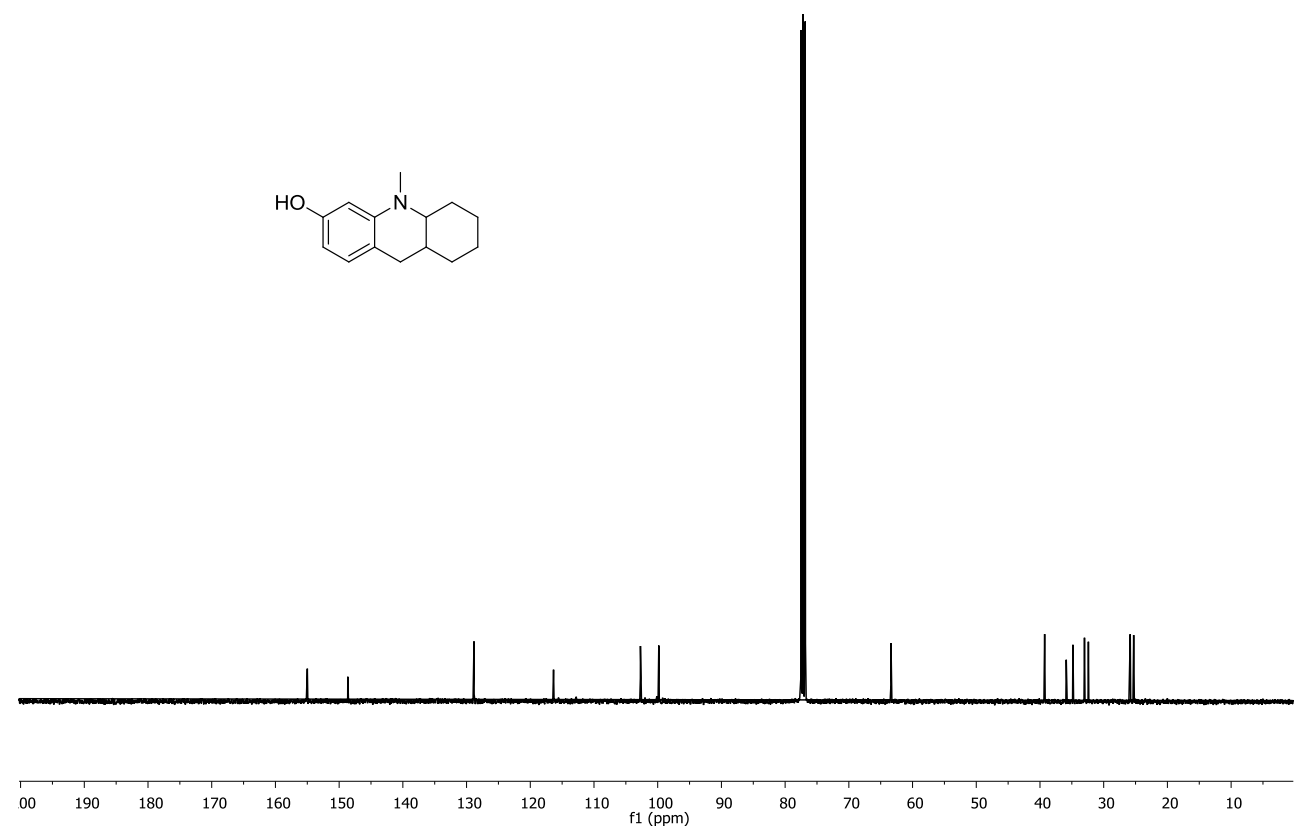

${ }^{13} \mathrm{C}$ NMR of compound 2.32

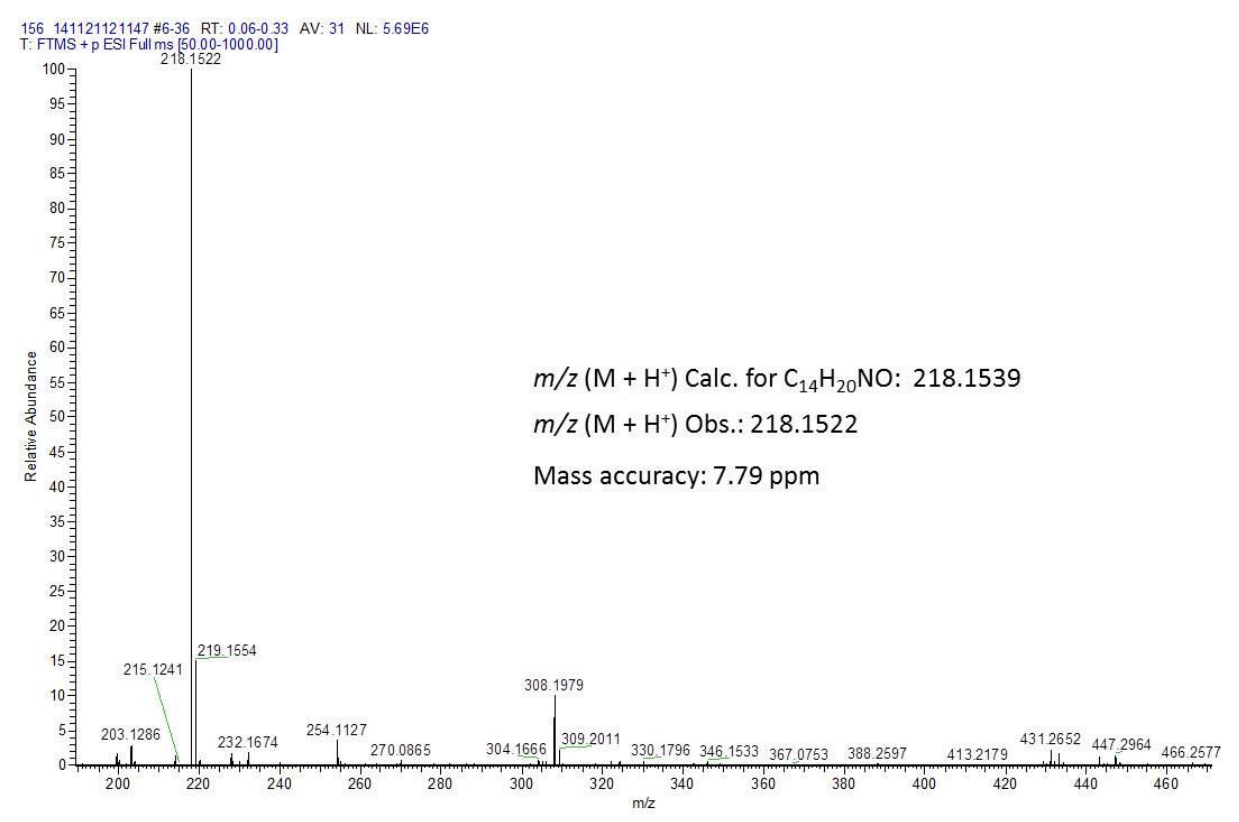

MS of compound 2.32 


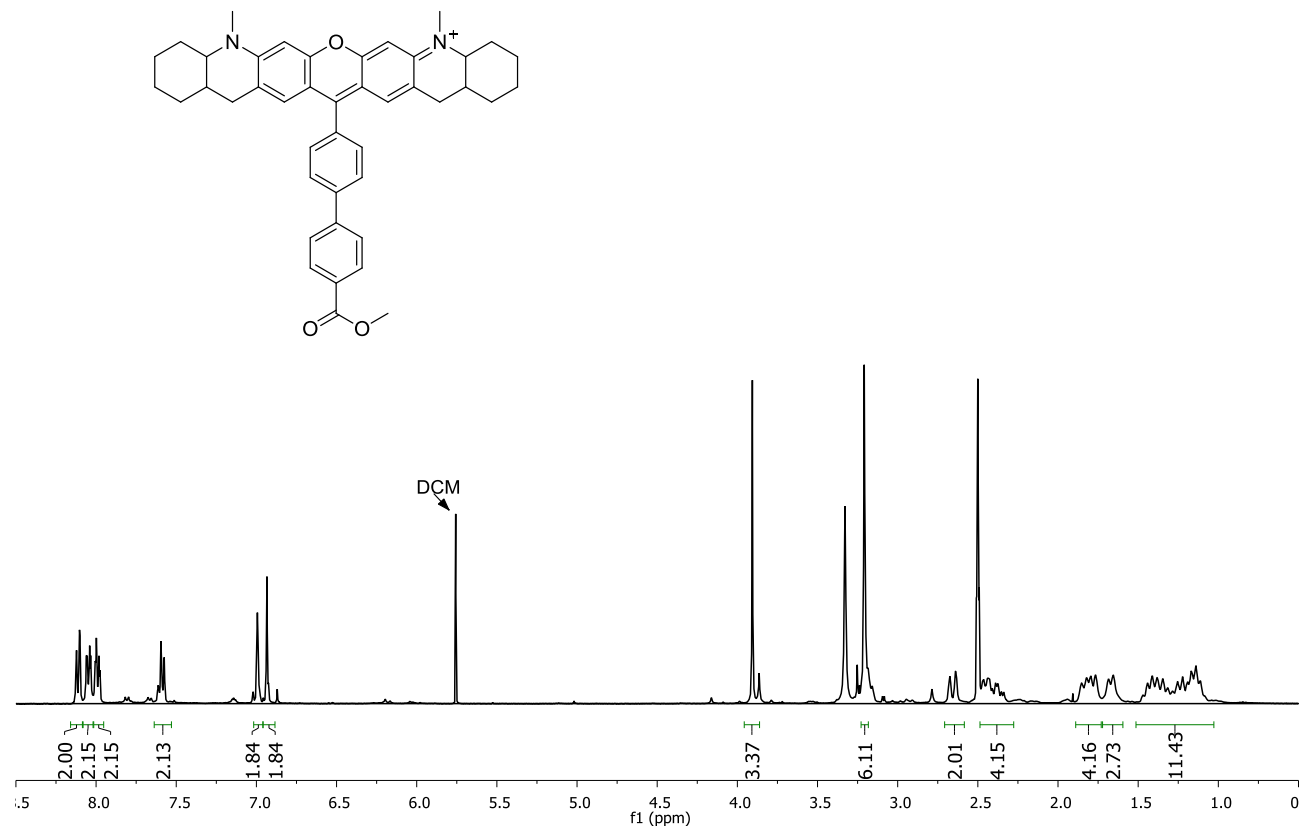

${ }^{1}$ H NMR of compound 2.45
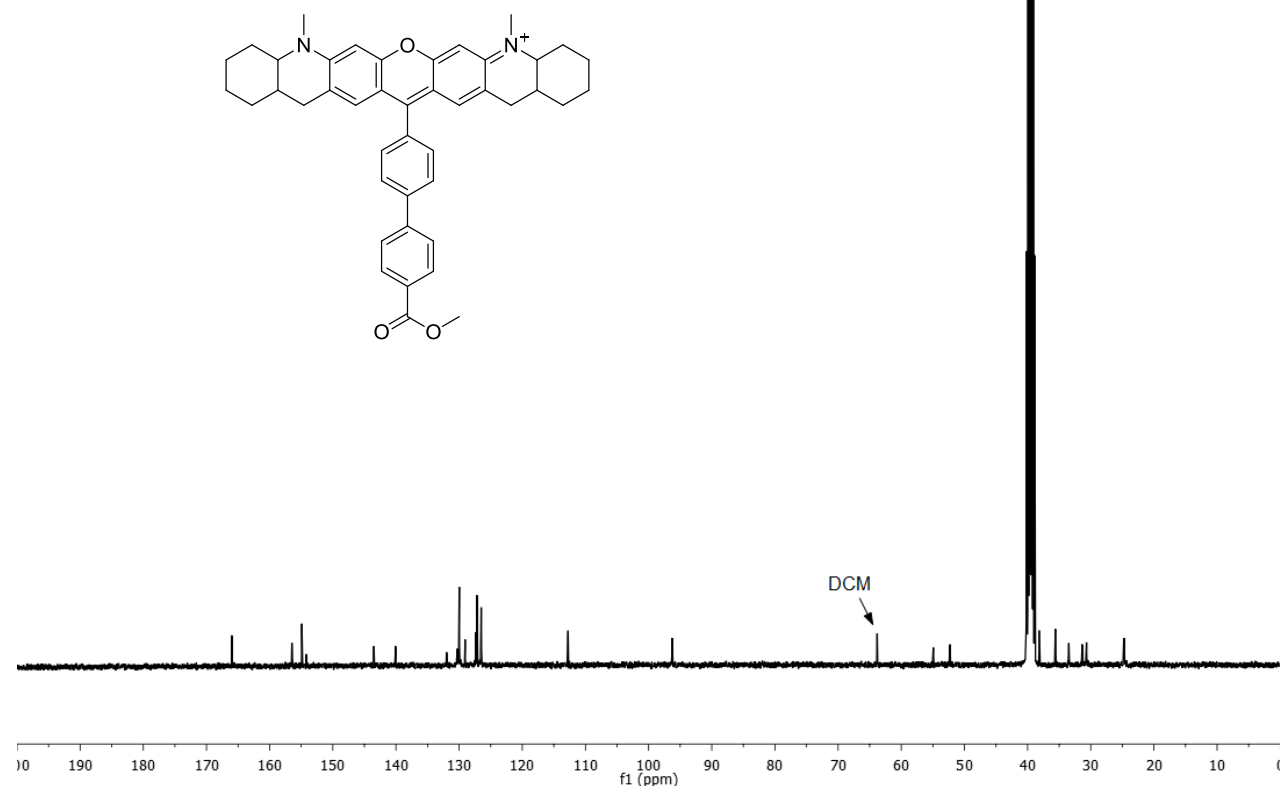

${ }^{13} \mathrm{C}$ NMR of compound 2.45 


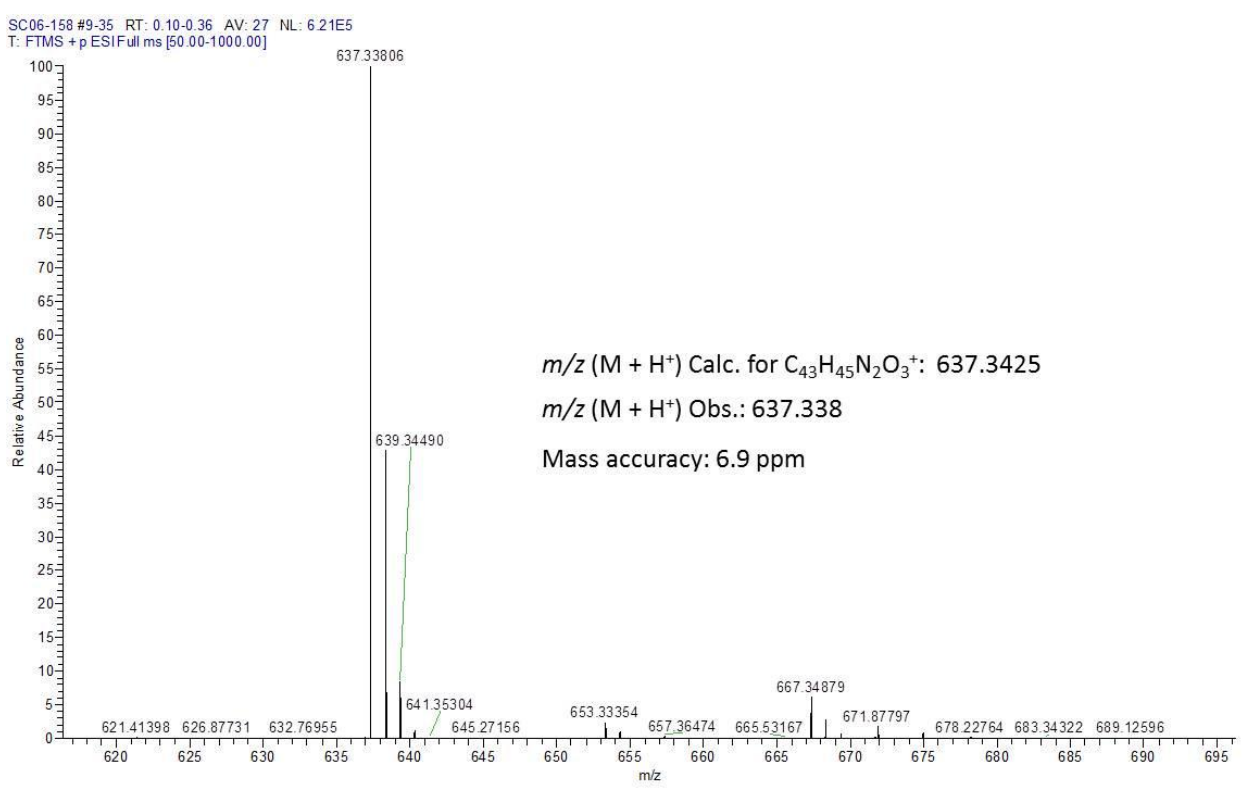

MS of compound 2.45
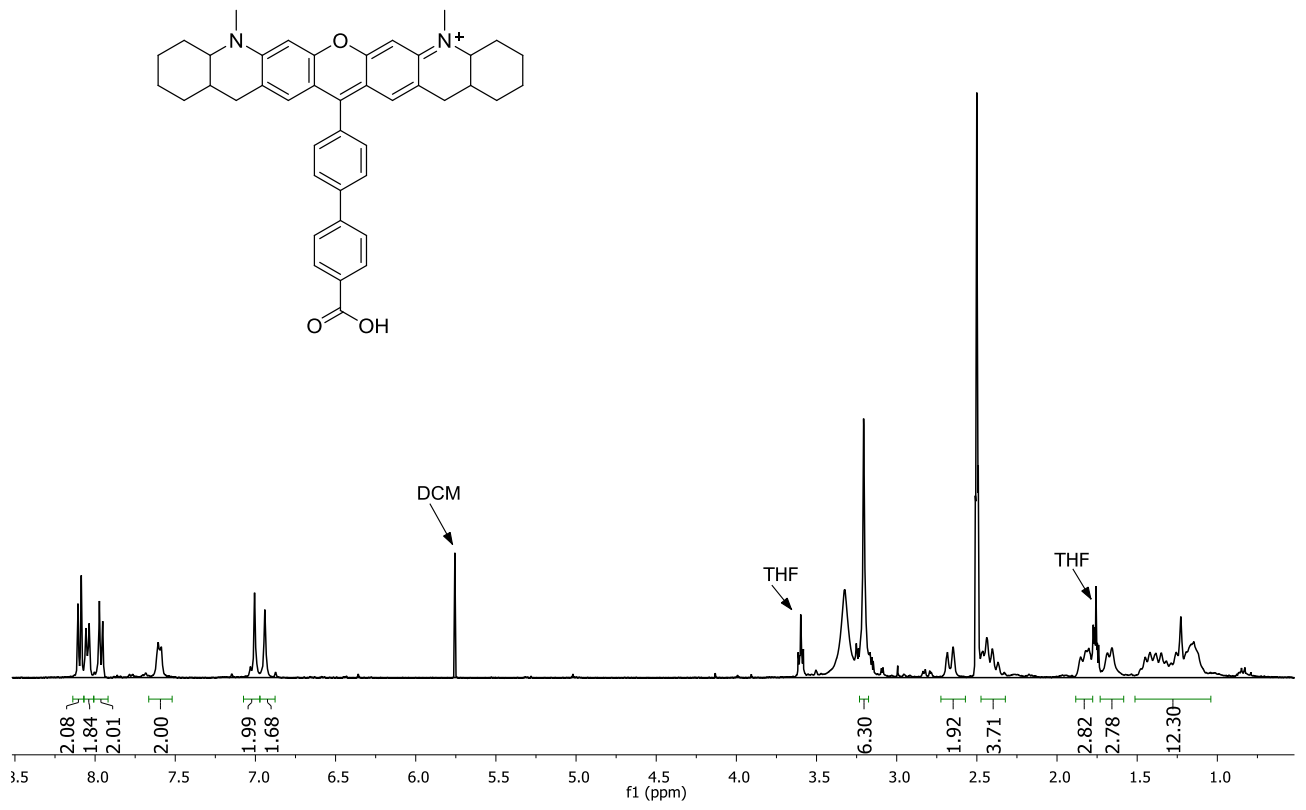

${ }^{1}$ H NMR of compound 2.46 

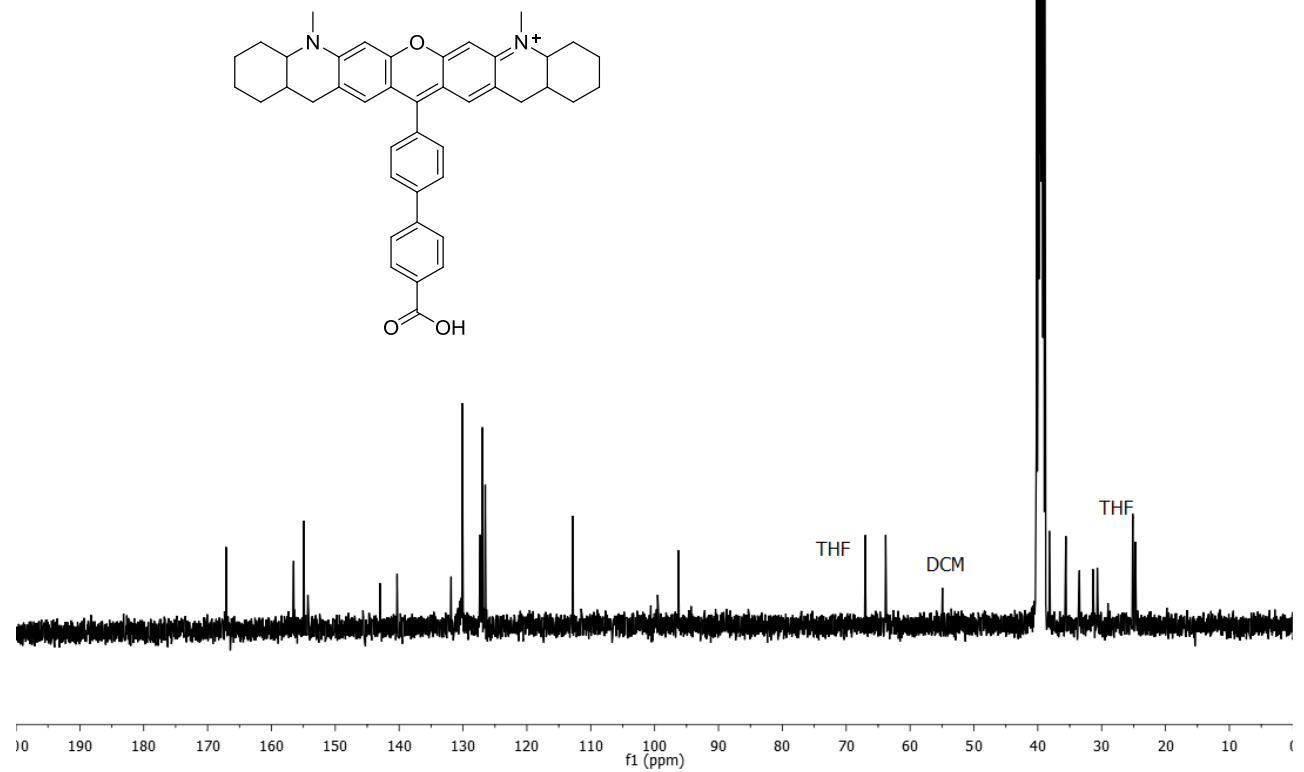

${ }^{13} \mathrm{C}$ NMR of compound 2.46

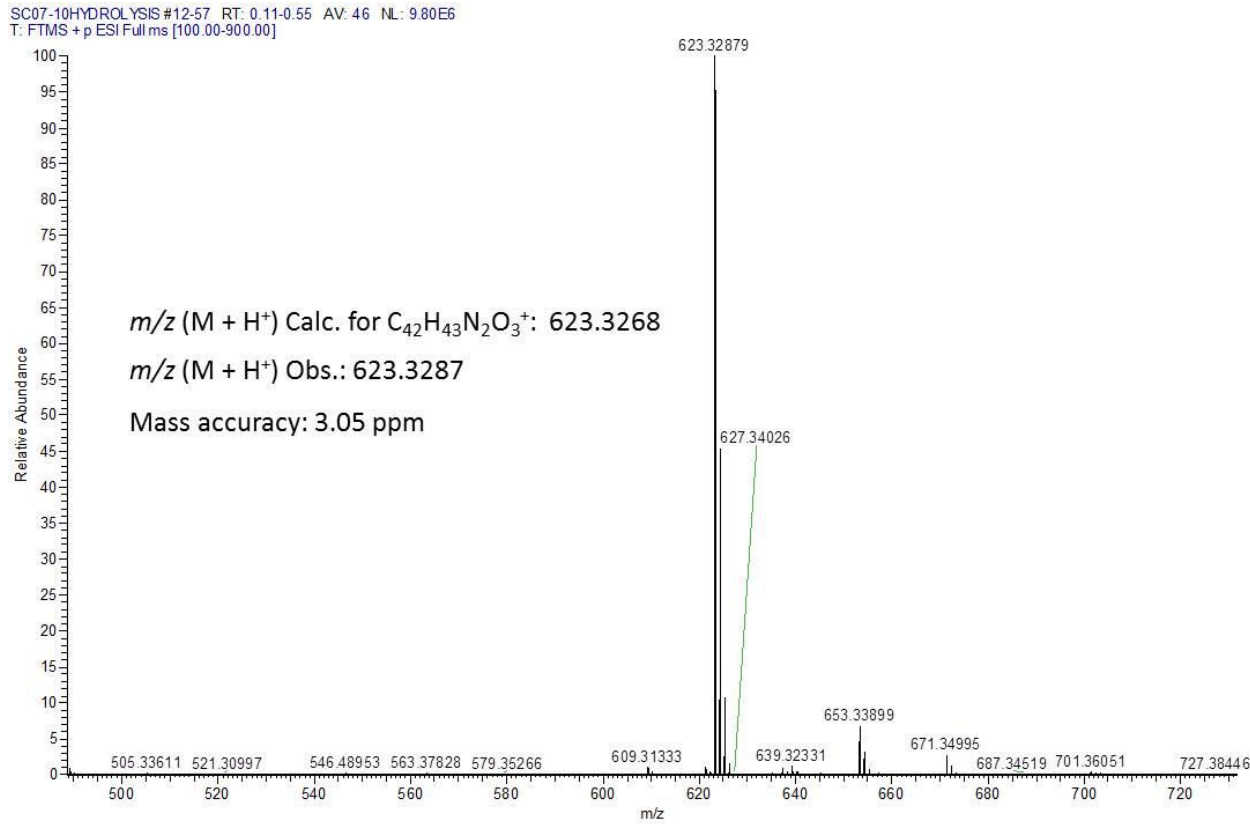

MS of compound 2.46 


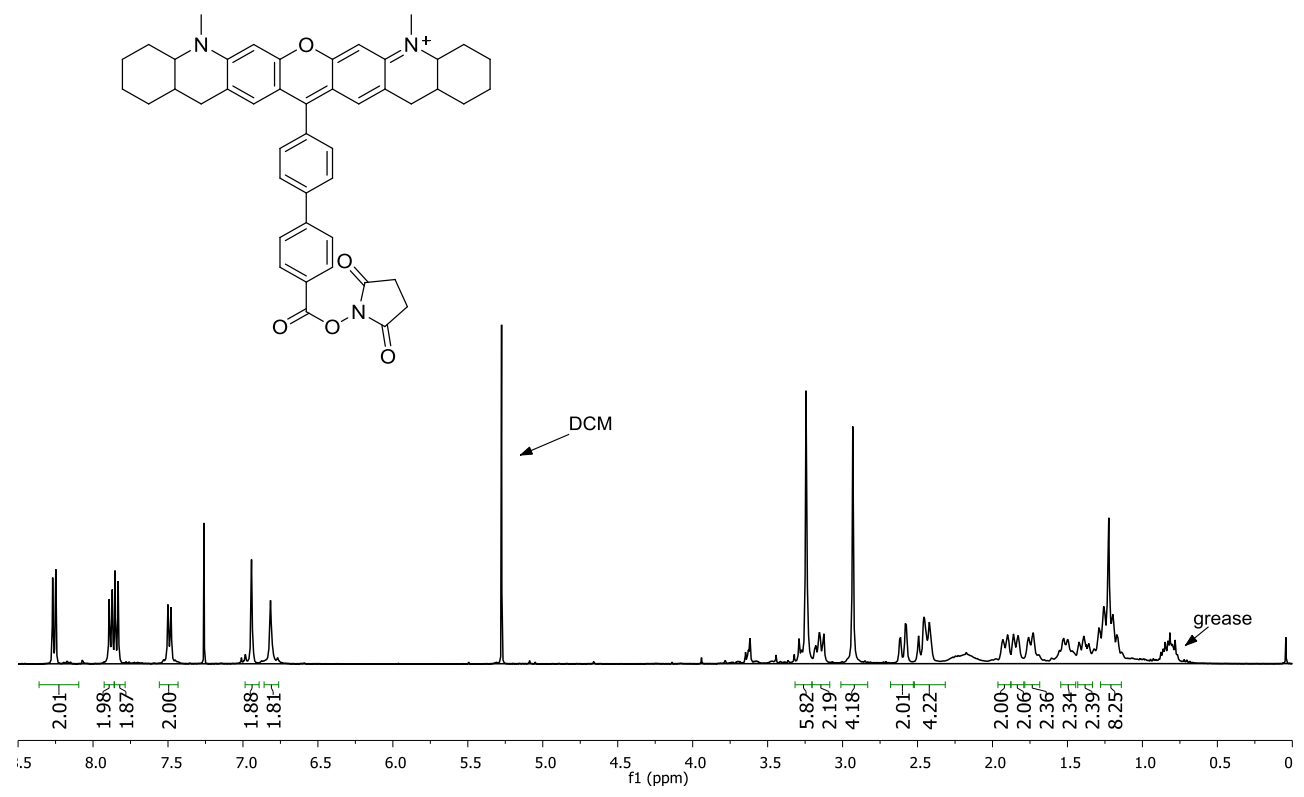

${ }^{1}$ H NMR of compound 2.8
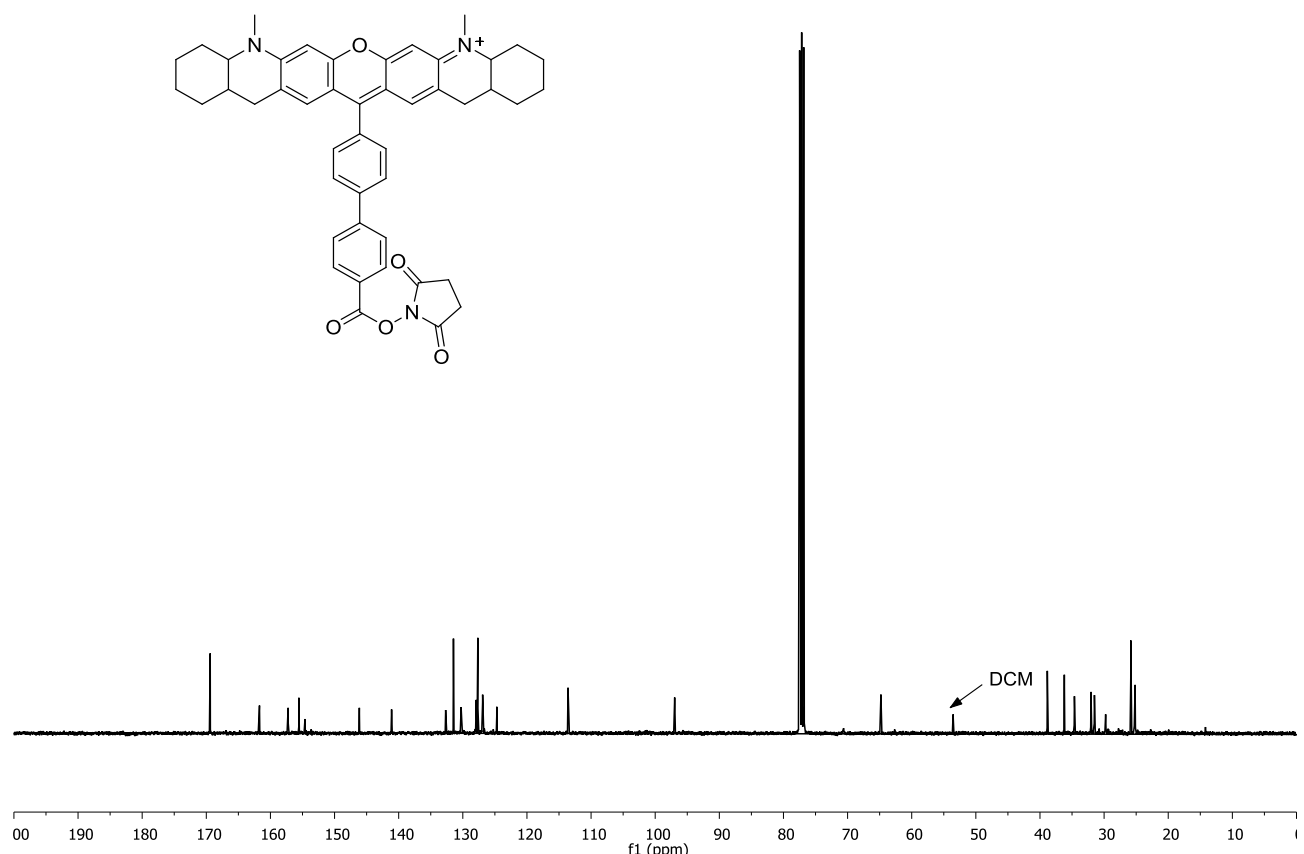

\section{${ }^{13} \mathrm{C}$ NMR of compound 2.8}




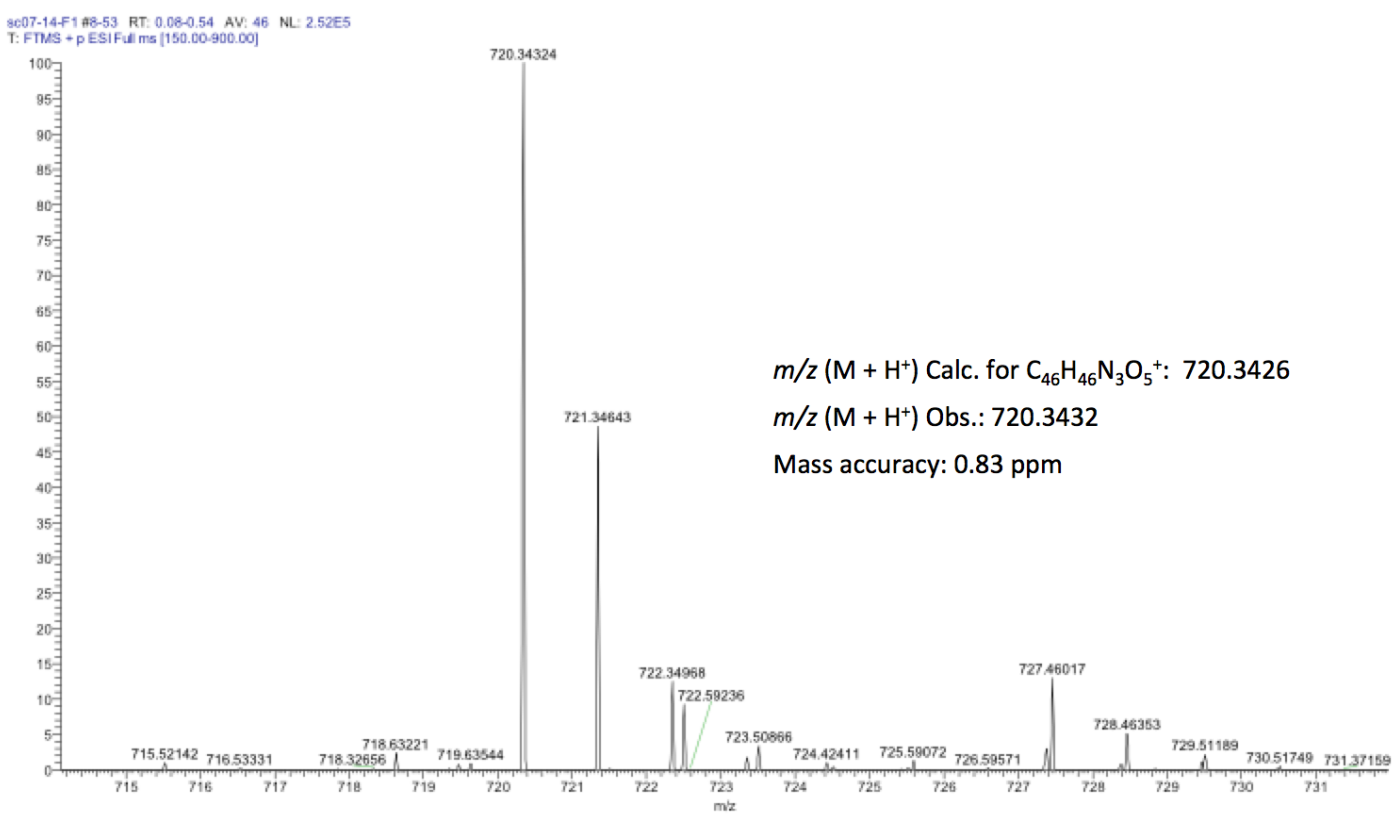

MS of compound 2.8 


\section{APPENDIX B: ${ }^{1} \mathrm{H}$ NMR, ${ }^{13} \mathrm{C}$ NMR, ${ }^{195} \mathrm{Pt}$ AND MS SPECTRA FOR SELECTED COMPOUNDS FROM CHAPTER 4}

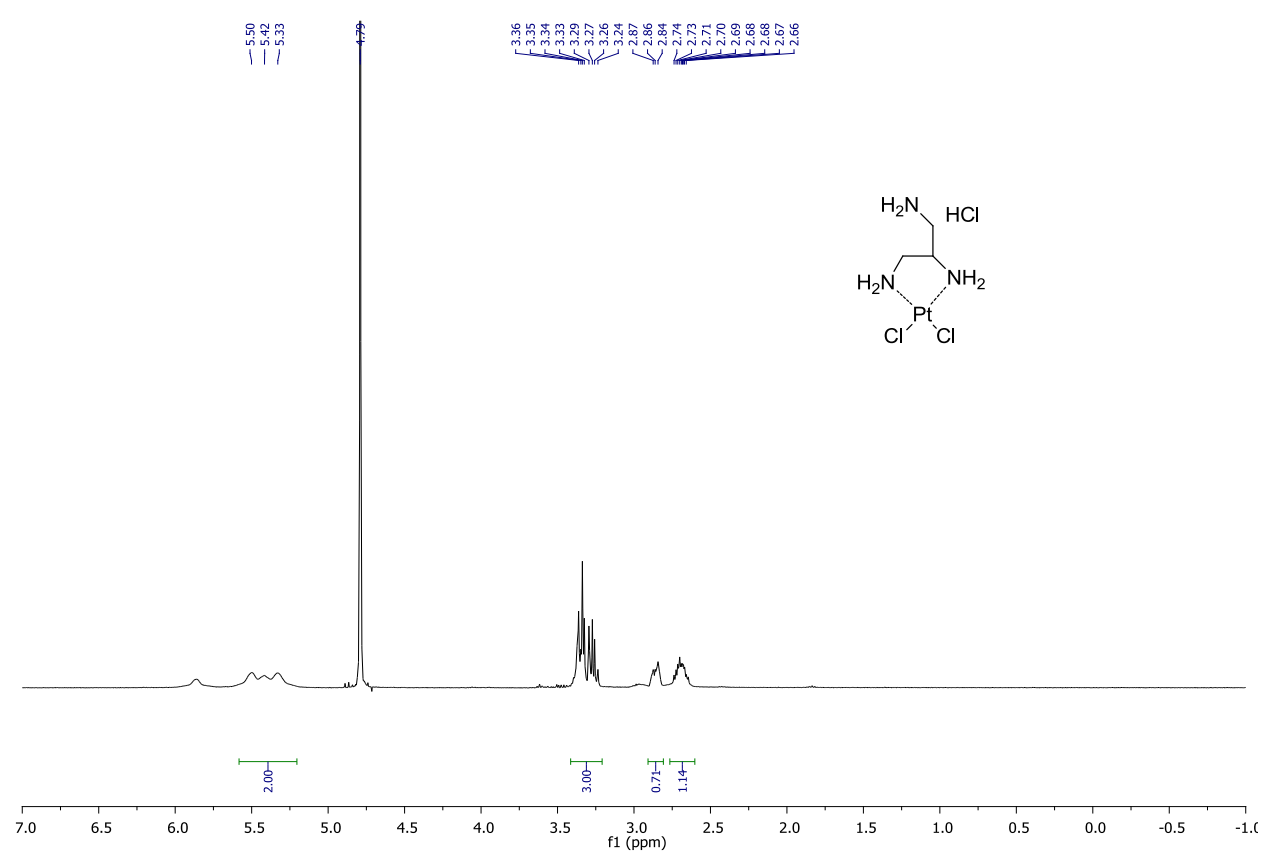

${ }^{1}$ H NMR of compound 4.5

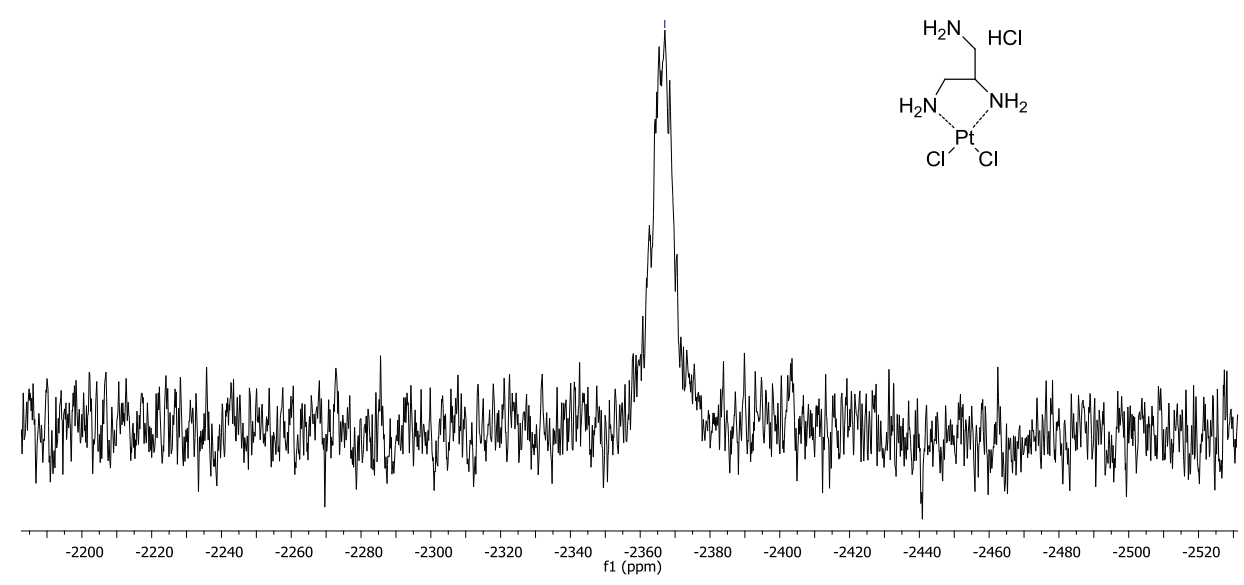

${ }^{195} \mathrm{Pt}$ NMR of compound 4.5 


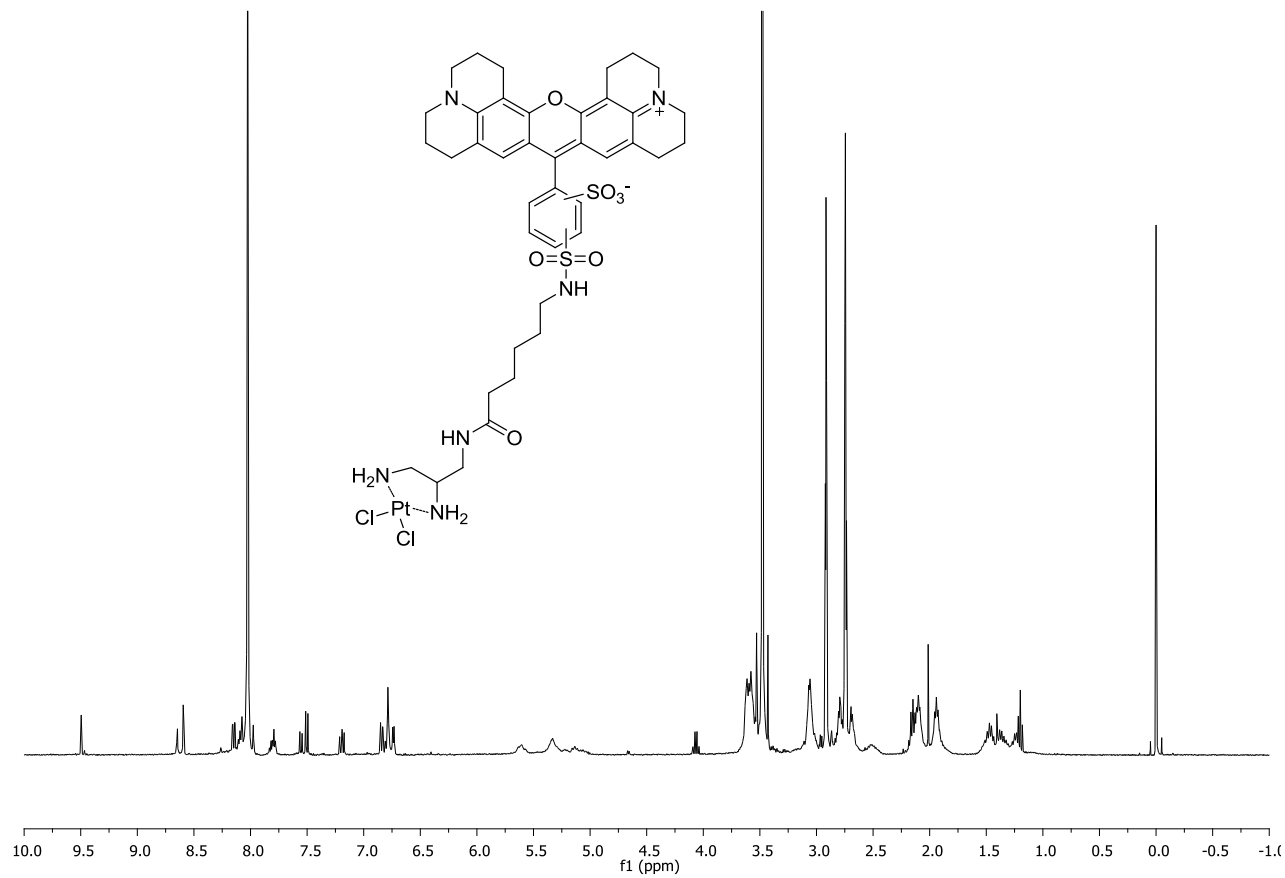

${ }^{1} \mathrm{H}$ NMR of compound 4.1

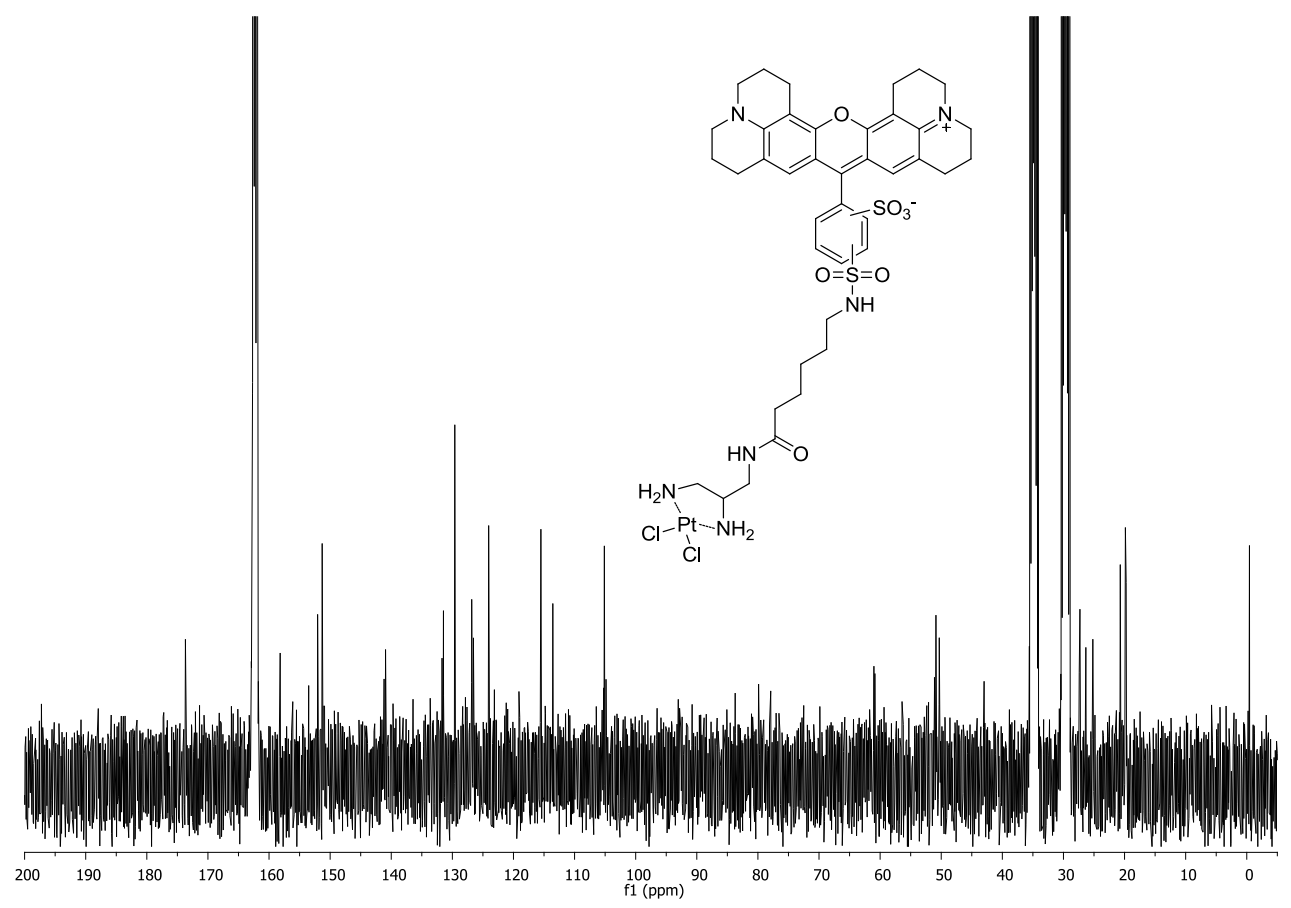

${ }^{13} \mathrm{C}$ NMR of compound 4.1 


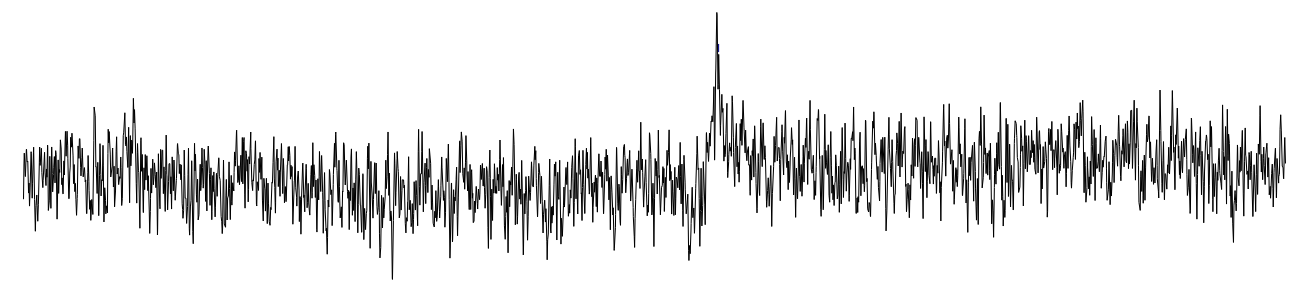

$\begin{array}{lllllllllllllllllllllllllll}-2040 & -2060 & -2080 & -2100 & -2120 & -2140 & -2160 & -2180 & -2200 & -2220 & -2240 & -2260 & -2280 & -2300 & -2320 & -2340 & -2360 & -2380 & -2400 & -2420 & -2440 & -2460\end{array}$

\section{${ }^{195} \mathrm{Pt}$ NMR of compound 4.1}

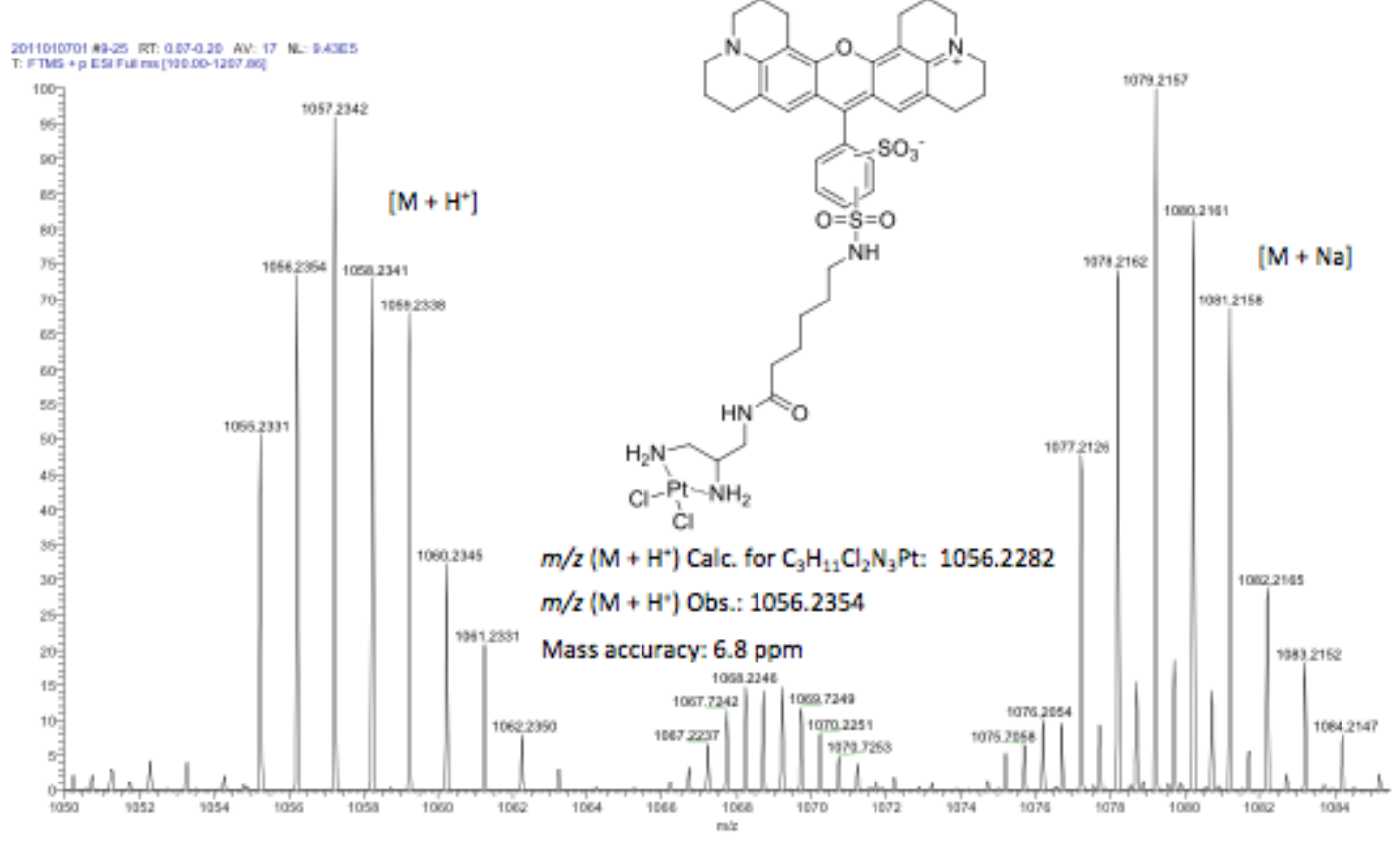

\section{MS of compound 4.1}




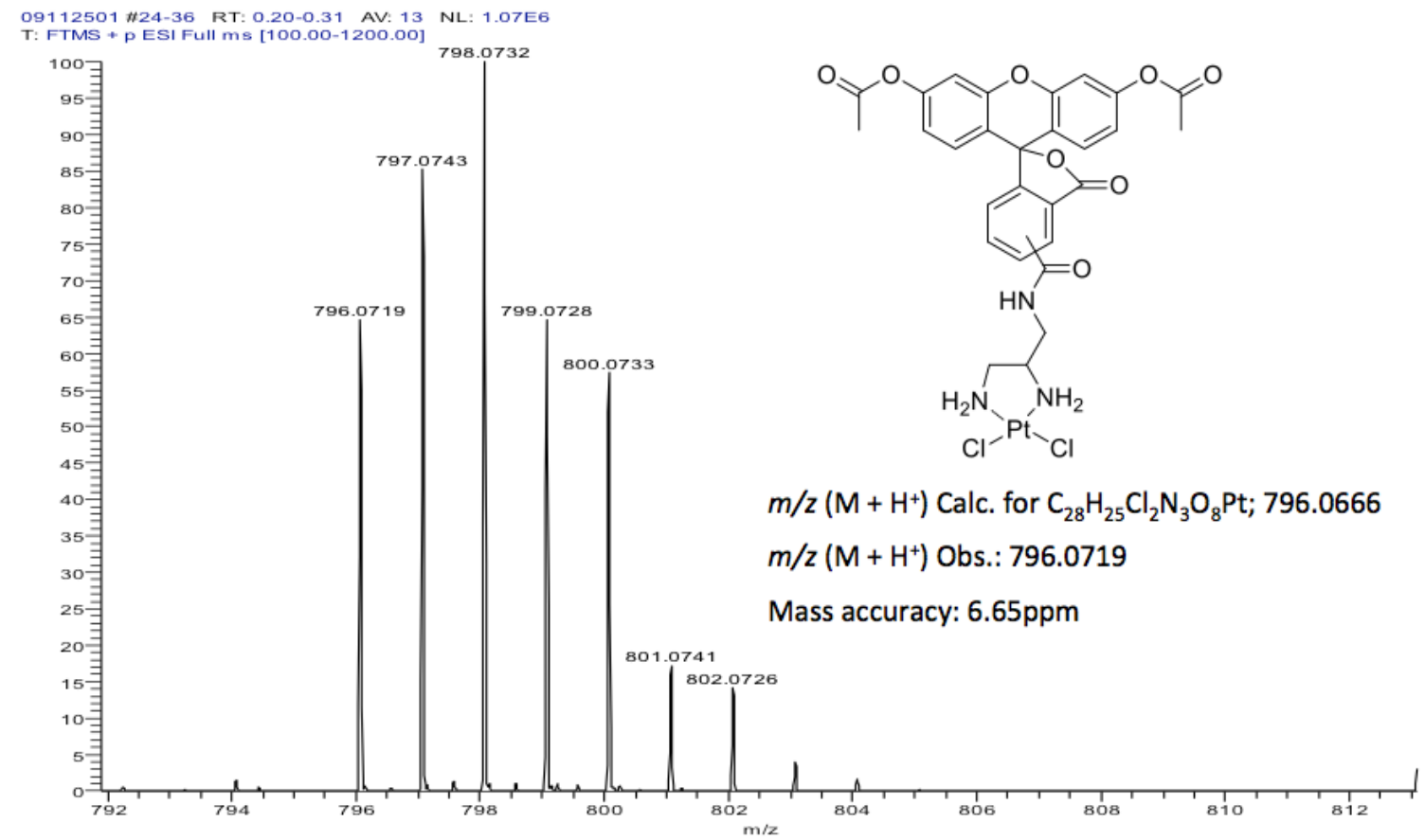

MS of compound 4.2 